UNIVERSIDADE DE SÃO PAULO

FACULDADE DE EDUCAÇÃO

LINGUAGEM E EDUCAÇÃO

SÉRGIO JOSÉ CUSTÓDIO

\title{
A emergência do discurso dos Sem \\ Universidade no Brasil
}

São Paulo

2014 


\section{SÉRGIO JOSÉ CUSTÓDIO}

A emergência do discurso dos Sem Universidade no Brasil

Dissertação apresentada à

Faculdade de Educação da Universidade de São Paulo para obtenção do título de Mestre em Educação.

Área de Concentração:

Linguagem e Educação

Orientador: Prof. Dr. Émerson de Pietri

São Paulo 
Nome: CUSTÓDIO, Sérgio José

Título: A emergência do discurso dos Sem Universidade no Brasil

Dissertação apresentada à Faculdade de Educação da Universidade de São Paulo para obtenção do título de Mestre em Educação.

Aprovado em 22 de setembro de 2014.

Banca Examinadora

Prof. Dr. Gabriel de Santis Feltran (Universidade Federal de São Carlos)

Prof. Dr. Sandoval Nonato Gomes Santos (Universidade de São Paulo) 


\section{RESUMO}

CUSTÓDIO, Sérgio José. A emergência do discurso dos Sem Universidade no Brasil. 2014. 306f. Dissertação (Mestado) - Faculdade de Educação, Universidade de São Paulo, São Paulo, 2014.

O objetivo da dissertação é caracterizar o processo de emergência do discurso dos Sem Universidade no Brasil. Para tanto, vale-se da observação da presença histórica dos discursos sobre as relações raciais no Brasil, como o embranquecimento, o mulatismo, a negritude, o indigenismo e o discurso dos povos indígenas no geral, e, em particular da percepção da reprodução, ocorrência, ecos, rumores desses respectivos discursos em um corpus específico, fruto de experiências de projetos de educação popular, realizados em cursinhos populares na periferia de São Paulo, no ano de 2003, com participantes egressos da escola pública e que não tiveram acesso às alterações de políticas educacionais relativas à incorporação transversal do ensino de história, cultura africana e dos povos indígenas na educação básica, obrigatórias apenas a partir de 2003 na letra da lei nacional. A pesquisa tem abordagem interdisciplinar e fundamentação teórica baseada nos estudos de análise de discurso, particularmente na categoria de interdiscurso. A metodologia vale-se da construção de um quadro de restrição semântica, da análise do corpus, do estabelecimento de relações com fontes semióticas complementares. Como resultado, o estudo indicou a presença do discurso de novíssimos sujeitos sociais, sua dimensão coletiva, sua imbricação institucional e a emergência do discurso do MSU, dos Sem Universidade, como indicia a luta comum por isenção de taxas dos vestibulares, por novas universidades públicas, pela criação de um sistema público de bolsas de estudos - o PROUNI, por uma reforma universitária popular, pelo ENEM como critério de acesso à universidade, pela aprovação da Lei de Cotas no Brasil (lei 12.711/12), pela instalação das Conferências Nacionais de Educação e pelo Plano Nacional de Educação no Brasil. 
Palavras-chave: Discursos sobre as relações raciais no Brasil; Novíssimos Movimentos Sociais; Cotas; Educação Popular

\begin{abstract}
CUSTÓDIO, Sérgio José. The emergence of the discourse of the "Sem Universidade" in Brazil. 2014. 302f. Dissertação (Mestrado) - Faculdade de Educação, Universidade de São Paulo, São Paulo, 2014.

The purpose of this work is to characterize the process of the discourse emerging from the Without University in Brazil. For that, it is worth-watching the historic presence of the speeches about race relations in Brazil, such as the discourse of whitening, mulatism, negritude, indianism, and the discourse of the brazilian native people, in general. Particularly, it matters the perception of the reproduction of these discourses, as well as its occurrences, echoes, rumors in a specific corpus. The corpus of this academic work was obtained from popular educational projects (preparatory courses to enter the university level) accomplished on the outskirts of São Paulo, in 2003, with students that came from the brazilian public educational system. As the teaching of African and brazilian native history and culture was introduced in basic education only from 2003, by the approval of a national law, the corpus analyzed has no influence of it. The research has an interdisciplinary approach but the theoretical framework is based on the study of discourse analysis with emphasis on interdiscourse. The methodology is based on a construction of one framework semantic constraints, the analysis of the corpus and in to see the relationships with complementary relevant semiotic sources.
\end{abstract}


Keywords: Discourse on race relations in Brazil, Without University, New Social Movements, quotas, popular education. 


\section{LISTA DE SIGLAS}

ABC - Conjunto de sete municípios da grande São Paulo, quais sejam, Santo André, São Bernardo do Campo, São Caetano do Sul, Diadema, Mauá, Ribeirão Pires e Rio Grande da Serra

AD - Análise do Discurso

CCJ - Comissão de Constituição, Justiça e Cidadania do Senado Federal

CCJC - Comissão de Constituição, Justiça e Cidadania da Câmara dos Deputados

CD - Câmara dos Deputados

CEDECA - Centro de Defesa da Criança e do Adolescente

CEE - Conselho Estadual de Educação

CEP - Código de Endereçamento Postal

CMP - Central de Movimentos Populares

$\mathrm{CN}$ - Congresso Nacional

COIAB - Coordenação das Organizações Indígenas da Amazônia

CONED - Congresso Nacional de Educação

CONEN - Coordenação Nacional das Entidades Negras

CPT - Comissão Pastoral da Terra

$\mathrm{D}$ - Documento de número $\mathrm{N}$ referenciado no corpus

DNA - Ácido Desoxirribonucleico (sigla em inglês)

E1 - o discurso do embranquecimento (discurso 1, por ordem de abordagem dos discursos na dissertação)

ECA - Estatuto da Criança e do Adolescente

ENEM - Exame Nacional do Ensino Médio

EUA - Estados Unidos da América

FATEC - Faculdade de Tecnologia

FNB - Frente Negra Brasileira

FNDEP - Fórum Nacional em Defesa da Escola Pública 
FSM - Fórum Social Mundial

FUNAI - Fundação Nacional do Índio

I3 - o discurso do indianismo (discurso 3, por ordem de abordagem dos discursos na dissertação);

IBGE - Instituto Brasileiro de Geografia e Estatística

ICMS - Imposto sobre Circulação de Mercadoria e Serviços

IEL - Instituto de Estudos da Linguagem da Universidade Estadual de Campinas

IHGB - Instituto Histórico e Geográfico Brasileiro

LDB - Lei de Diretrizes e Bases da Educação Nacional, Lei 9394/96

M1 - Referência ao discurso do embranquecimento (E1) no quadro de restrição semântica da competência discursiva ampliada para o espaço discursivo em análise M2 - Referência ao discurso do mulatismo (ML2) no quadro de restrição semântica da competência discursiva ampliada para o espaço discursivo em análise

M3 - Referência ao discurso do indianismo (I3) no quadro de restrição semântica da competência discursiva ampliada para o espaço discursivo em análise

M4 - Referência ao discurso da negritude (N4) no quadro de restrição semântica da competência discursiva ampliada para o espaço discursivo em análise

M5 - Referência ao discurso dos povos indígenas (PI5) no quadro de restrição semântica da competência discursiva ampliada para o espaço discursivo em análise

ML2 - Discurso do mulatismo (discurso 2, por ordem de abordagem dos discursos na dissertação)

MNU - Movimento Negro Unificado Contra a Discriminação Racial

MST - Movimento dos Trabalhadores Rurais Sem Terra

MSU - Movimento dos Sem Universidade

N4 - Discurso da negritude (discurso 4, por ordem de abordagem dos discursos na dissertação)

ND - Núcleo Discursivo

NMS - Novos Movimentos Sociais

N*MS - Novíssimos Movimentos Sociais

NUPES - Núcleo de Estudos Sobre Ensino Superior da Universidade de São Paulo

OBS - Observação

ONG - Organização Não Governamental

ONU - Organização das Nações Unidas

PAS - Programa de Avaliação Seriada 
PI5 - Discurso dos povos indígenas (discurso 5, por ordem de abordagem dos discursos na dissertação)

PJMP - pastoral da juventude do meio popular

PL - Projeto de Lei

Prouni - Programa Universidade Para Todos

PUC-SP - Pontifícia Universidade Católica de São Paulo

Q1 - questão 1 referenciada no corpus

Q5 - questão 5 referenciada no corpus

$\mathrm{R}$ - Redação correspondente ao documento numerado referenciada no corpus

$\mathrm{SF}$ - Senado Federal

SME - Secretaria Municipal de Educação

SPI - Serviço de Proteção ao Índio

STF - Supremo Tribunal Federal

T1 a T7 - Textos da mediação epistêmica comum presente nos documentos do corpus

TEN - Teatro Experimental do Negro

TL - Teologia da Libertação

UFRJ - Universidade Federal do Rio de Janeiro

UnB - Universidade de Brasília

UNE - União Nacional dos Estudantes

UNESCO - Organização das Nações Unidas para a educação, a ciência e a cultura

UNESP - Universidade Estadual Paulista

Unicamp - Universidade Estadual de Campinas

URSS - União das Repúblicas Socialistas Soviéticas

USP - Universidade de São Paulo

VUNESP - Fundação para o Vestibular da Universidade Estadual Paulista 


\section{LISTA DE TABELAS}

Tabela 1 - População por raça ou cor, segundo o Distrito Administrativo - Município de

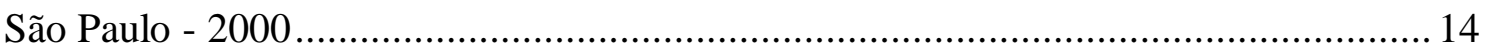

Tabela 2 - Duas definições de habitus (Latim). HANKS, 2008, p. 41 .......................... 87 Tabela 3 - Quadro de restrição semântica da competência discursiva ampliada para o espaço discursivo das relações raciais no Brasil, considerando-se aspectos sociais, culturais, econômicos e políticos (M1 = discurso do embranquecimento; M2 = discurso do mulatismo; M3 = discurso do indianismo; $\mathrm{M} 4=$ discurso da negritude; $\mathrm{M} 5=$

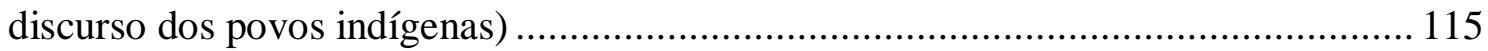

Tabela 4 - Núcleos discursivos vis-à-vis a amostra analítica eleita............................ 165 


\section{LISTA DE FIGURAS}

Figura 1 - Mapa da Vulnerabilidade Social - Município de São Paulo - 2000................. 11

Figura 2 - Esquema de ADAM (adaptado) .......................................................... 83

Figura 3 - Georreferenciamento - distribuição geográfica no município de São Paulo (SP) do local de moradia dos Sem Universidade participantes do projeto de educação popular, do cursinho popular do MSU na zona leste de São Paulo, em Guaianases, localizado na Rua Antonio Thadeo, 309 (2003)

Figura 4 - Georreferenciamento - distribuição geográfica no município de São Paulo (SP) do local de moradia dos Sem Universidade participantes do projeto de educação popular, do cursinho popular do MSU na zona sul de SÃO PAULO, no Jardim Ângela, na Rua Marcelino Coelho, 297 (2003) 137

Figura 5 - Georreferenciamento - distribuição geográfica no município de São Paulo (SP) do local de moradia dos Sem Universidade participantes do projeto de educação popular, do cursinho popular do MSU na zona leste, em Cidade AE Carvalho, na Avenida das Alamandas, 36 (2003). 138

Figura 6 - Georreferenciamento - distribuição geográfica no município de São Paulo (SP) do local de moradia dos Sem Universidade participantes do projeto de educação popular, do cursinho popular do MSU na zona leste, em Cidade Tiradentes, na Avenida dos Têxteis, 2907 (2003) 139

Figura 7 - Raça/Cor autodeclarada dos Sem Universidade participantes do projeto de educação popular, do cursinho popular do MSU em 2003. 148 Figura 8 - Raça/Cor conforme o IBGE apropriado da figura 7 da autodeclaração dos Sem Universidade participantes do projeto de educação popular, do cursinho popular do MSU em 2003 148

Figura 9 - Distribuição da chefia de família conforme autodeclaração dos Sem Universidade participantes do projeto de educação popular, do cursinho popular do MSU em 2003 149

Figura 10 - Sexo conforme autodeclaração dos Sem Universidade participantes do projeto de educação popular, do cursinho popular do MSU em 2003 149

Figura 11 - Origem escolar pessoal conforme autodeclaração dos Sem Universidade participantes do projeto de educação popular, do cursinho popular do MSU em 2003

Figura 12 - Escola em que concluiu o ensino médio conforme autodeclaração dos Sem Universidade participantes do projeto de educação popular, do cursinho popular do MSU em 2003. 150 
Figura 13 - Formação escolar da Mãe conforme autodeclaração dos Sem Universidade, participantes do projeto de educação popular, do cursinho popular do MSU em 2003

Figura 14 - Formação escolar do Pai conforme autodeclaração dos Sem Universidade, participantes do projeto de educação popular, do cursinho popular do MSU em 2003

Figura 15 - Hábito de estudo conforme autodeclaração dos Sem Universidade, participantes do projeto de educação popular, do cursinho popular do MSU em 2003

Figura 16 - DISCURSOS OUTROS (último livro lido em 2003), conforme autodeclaração dos Sem Universidade participantes do projeto de educação popular, do cursinho popular do MSU em 2003 153

FIGURA 17 - CAPA DO JORNAL FOLHA DE SÃO PAULO DÁ MANCHETE À LUTA DOS SEM UNIVERSIDADE EM PROL DA ISENÇÃO DAS TAXAS COBRADAS PELAS UNIVERSIDADES PÚBLICAS PAULISTAS NO VESTIBULAR.

Erro! Indicador não definido. FIGURA 18 - MATÉRIA DADA PELO JORNAL FOLHA DE SÃO PAULO SOBRE MANIFESTAÇÃO DO MSU NA ASSEMBLEIA LEGISLATIVA DO ESTADO DE SÃO PAULO, PELA ISENÇÃO DAS TAXAS DOS VESTIBULARES NAS UNIVERSIDADES PÚBLICAS PAULISTAS. Erro! Indicador não definido. FIGURA 19 - NOTA SOBRE REPRESENTAÇÃO DO MSU NO MINISTÉRIO PÚBLICO PAULISTA CONTRA DECISÃO DO CONSELHO ESTADUAL DE EDUCAÇÃO QUE VETOU A CRIAÇÃO DA UNIVERSIDADE MUNICIPAL DA CIDADE DE SÃO PAULO, PROPOSTA APRESENTADA PELO MSU EM 2002. Erro! Indicador não definido. FIGURA 20 - ENCONTRO DO MSU NA RUA TABATINGUERA 292, QUADRA DOS BANCÁRIOS, EM 2005. Erro! Indicador não definido. FIGURA 21 - ENCONTRO DO MSU EM 2005: OS NOVÍSSIMOS SUJEITOS SOCIAIS. ... Erro! Indicador não definido.

FIGURA 22 - ENCONTRO DO MSU EM 2005: UMA NOVA EDUCAÇÃO POPULAR NASCE NAS PERIFERIAS. Erro! Indicador não definido. FIGURA 23 - ENCONTRO DO MSU EM 2005: PROTAGONISMO POPULAR EM TODAS AS IDADES. Erro! Indicador não definido. FIGURA 24 - ENCONTRO DO MSU EM 2005: DILMA, QUE PARTICIPOU DA LUTA DOS EXCEDENTES PELO DIREITO À UNIVERSIDADE NOS ANOS 1960, ACENDE A CHAMA DA LUTA QUE PASSA DE MÃO EM MÃO NA HISTÓRIA DO MSU.Erro! Indicador não definido.

FIGURA 25 - ENCONTRO DO MSU EM 2005: A TOCHA ACESSA PASSA DE MÃO EM MÃO COMPARTILHANDO A RESPONSABILIDADE COLETIVA DOS NOVÍSSIMOS SUJEITO SOCIAIS. Erro! Indicador não definido. FIGURA 26 - ENCONTRO DO MSU EM 2005: APLAUSOS PARA A TOCHA ACESA ....... Erro! Indicador não definido. 
FIGURA 27 - ENCONTRO DO MSU EM 2005: O RECONHECIMENTO DA HERANÇA DISCURSIVA NUM BOTÃO DE FLOR ENTREGUE A DILMA... Erro! Indicador não definido. FIGURA 28 - ENCONTRO DO MSU EM 2005: A TOCHA NO MEIO DO POVO.............. Erro! Indicador não definido.

FIGURA 29 - ENCONTRO DO MSU EM 2005: FORTE PRESENÇA POPULAR DAS FAMÍLIAS.

Erro! Indicador não definido.

FIGURA 30 - ENCONTRO DO MSU EM 2005: PASSAGEM DA TOCHA E DA LUTA. ..... Erro! Indicador não definido.

FIGURA 31 - ENCONTRO DO MSU EM 2005: O MOMENTO DE PASSAGEM DA TOCHA DA LUTA DOS EXCEDENTES PARA A LUTA DO MSU. ........... Erro! Indicador não definido. FIGURA 32 - ENCONTRO DO MSU EM 2005: CARLÃO ACENDE A TOCHA NAS MÃOS DE DILMA, QUE PARTICIPOU ATIVAMENTE DA LUTA DOS EXCEDENTES NOS ANOS 1960 NO BRASIL

Erro! Indicador não definido. FIGURA 33 - ENCONTRO DO MSU EM 2005: FLORES E HOMENAGEM.Erro! Indicador não definido.

FIGURA 34 - NA CRISE POLÍTICA DE 2005 O MSU TOMA POSIÇÃO NA DEFESA DO GOVERNO DE UM SEM UNIVERSIDADE, O PRESIDENTE LULA, COMO NESTE ENCONTRO EM CIDADE TIRADENTES: COMPROMISSO DO PRESIDENTE LULA DE CRIAR A UFABC E ABRIR AS PORTAS DA UNIVERSIDADE PARA O POVO! ........ Erro! Indicador não definido. FIGURA 35 - NO SENADO FEDERAL EM DEZEMBRO DE 2004 COM O SENADOR NEGRO PAULO PAIM, NA PAUTA A LUTA PELA GARANTIA DA CRIAÇÃO DO SISTEMA NACIONAL DE BOLSAS, O PROUNI, IDEIA QUE BROTA DA LUTA DO MSU NA PERIFERIA DE SÃO PAULO EM 2002.

Erro! Indicador não definido.

FIGURA 36 - MANIFESTAÇÃO CONTRA O RACISMO NA FACULDADE DE DIREITO DA USP E ENTERRO DA INTOLERÂNCIA EM FRENTE À ESTA INSTITUIÇÃO NO ANO DE 2006. EM 2007 O MSU PARTICIPARIA DA OCUPAÇÃO DO LARGO SÃO FRANCISCO EM DEFESA DE COTAS NA USP, QUANDO TOM ZÉ VESTE A CAMISA DO MSU.Erro! Indicador não definido.

FIGURA 37 - MANIFESTAÇÃO DO MSU NACÂMARA DOS DEPUTADOS EM AUDIÊNCIA PÚBLICA EM BRASÍLIA NO PRIMEIRO SEMESTRE DE 2006: DEFESA DA APROVAÇÃO INTEGRAL DO PL 73/99, O PL DE COTAS, COMO APROVADO NA COMISSÃO DE EDUCAÇÃO E DIREITOS HUMANOS EM 2005. Erro! Indicador não definido. FIGURA 38 - SEM UNIVERSIDADE NO CURSINHO POPULAR EM GUAIANASES, PERFERIA DE SÃO PAULO, 2003. Erro! Indicador não definido. FIGURA 39 - MANIFESTAÇÃO NO PORTÃO PRINCIPAL DA USP EM 2003: BANDEIRA DE UMA REFORMA UNIVERSITÁRIA POPULAR APARECE! AS BECAS NA CENA SIMBOLIZAM O DISCURSO DA EXCLUSÃO DA UNIVERSIDADE NO BRASIL Erro! Indicador não definido. FIGURA 40 - RECONHECIMENTO PÚBLICO DA PRESIDÊNCIA DA REPÚBLICA FEDERATIVA DO BRASIL DO PAPEL DO MSU NA CONQUISTA DO PROUNI NO BRASIL: O MSU FALA NA CERIMÔNIA DE LANÇAMENTO DO PROUNI EM 13 DE JANEIRO DE 2005 NO PALÁCIO DO PLANALTO EM BRASÍLIA. Erro! Indicador não definido. 
FIGURA 41 - MARCHA DO MSU DA FAVELA AO LADO DA DASLU ATÉ A LOJA DE LUXO: CONTRA A DESIGUALDADE SOCIAL NO BRASIL, 2005. ........ Erro! Indicador não definido. FIGURA 42 - MARCHA DO MSU NA DASLU EM 2005......... Erro! Indicador não definido. FIGURA 43 - EM DUAS PLACAS DE PEDRA, COMO OS DEZ MANDAMENTOS DE MOISÉS, O MSU ENTREGA AO MINISTÉRIO DA EDUCAÇÃO 10 PROPOSTAS PARA UMA REFORMA UNIVERSITÁRIA POPULAR NO BRASIL. O ENEM COMO CRITÉRIO DE ACESSO APARECE COMO PRIMEIRA PROPOSTA INSCRITA NA PEDRA. A JORNALISTA LUCIANA CONSTANTINO, DA SUCURSAL DE BRASÍLIA DO JORNAL FOLHA DE SÃO PAULO, COBRIU REGISTROU ESTE ATO PARA A HISTÓRIA DO BRASIL EM 2005.Erro! Indicador não definido.

FIGURA 44 - NENHUM A MENOS: MANIFESTÇÃO EM FRENTE À USP: 300 KILOS DE BANANAS SÃO ENTREGUES NO PORTÃO DA USP CONTRA O ELITISMO DESSA UNIVERSIDADE E POR SUA DEMOCRATIZAÇÃO SOCIAL E RACIAL.Erro! Indicador não definido.

Agradecimento

Aos Sem Universidade do Brasil

Pará minha avó negra Maria Isaura de Jesus

Pará minha bisavó indígena Francisca Maria de Jesus 


\section{SUMÁRIO}

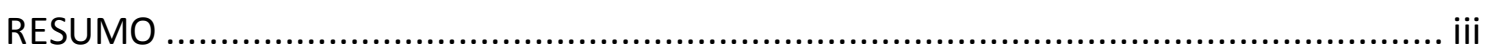

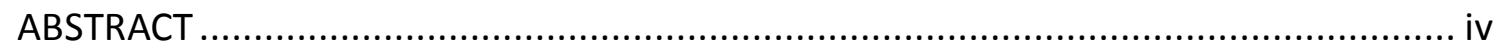

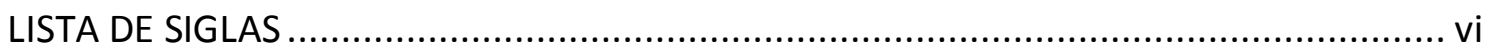

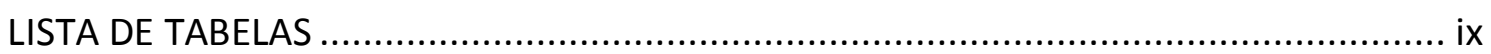

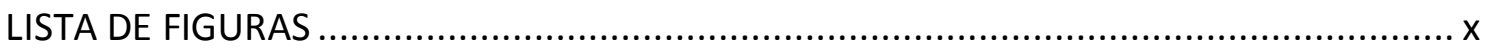

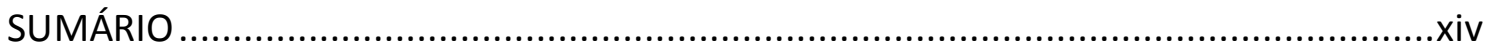

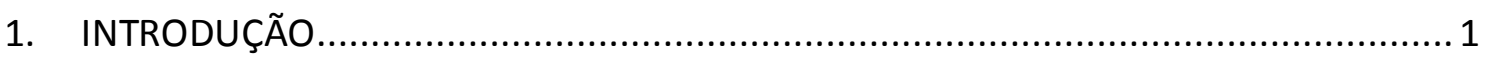

1.1. Chão da memória................................................................................ 1

1.2. Pés na estrada da educação popular ........................................................ 4

1.3. No meio do caminho a linguagem nas relações raciais no Brasil.................... 17

1.4. No ar do Brasil uma artimanha discursiva dominante ................................. 23

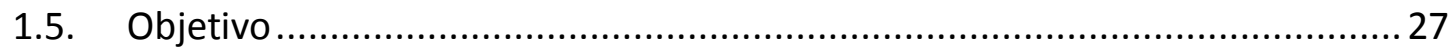

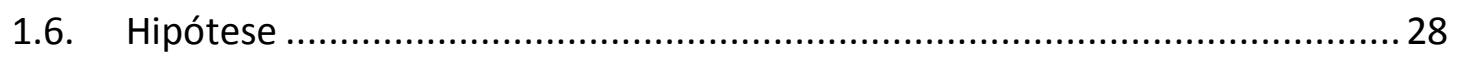

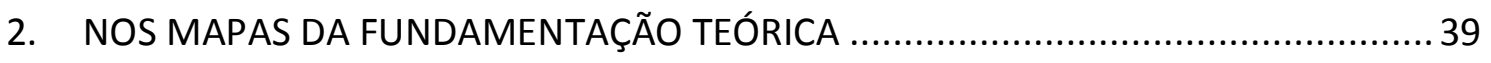

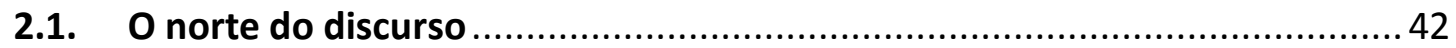

2.2. Heterogeneidades no fio do discurso.................................................. 47

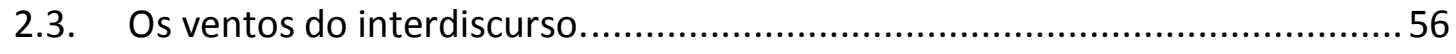

2.4. O constructo do quadro de restrição semântica da competência discursiva

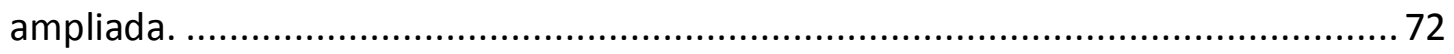

2.5. Discurso, incorporação, habitus e prática discursiva .................................... 84

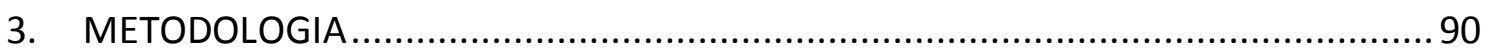

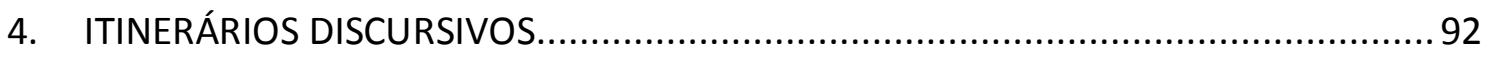

4.1. O espaço discursivo e os discursos constituintes ....................................... 92

4.2. O discurso do embranquecimento ou branqueamento .............................. 93 


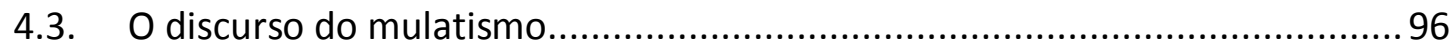

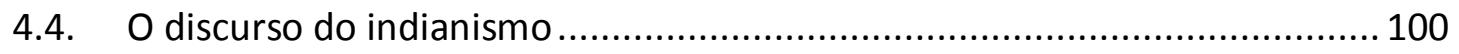

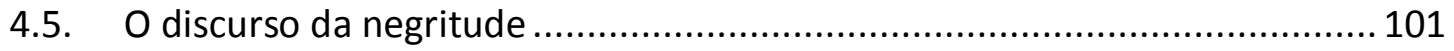

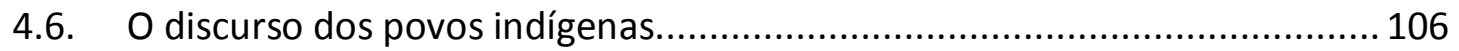

4.7. Exercício de construção de um quadro de restrição semântica .................... 110

4.8. O discurso de Uns versus o discurso dos Outros....................................... 117

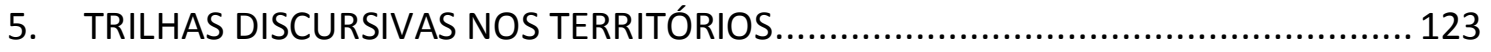

5.1. Novíssimos sujeitos sociais fragmentados em territórios da periferia?........ 123

5.1.1. Pelos caminhos dos discursos dos novíssimos sujeitos sociais .................... 133

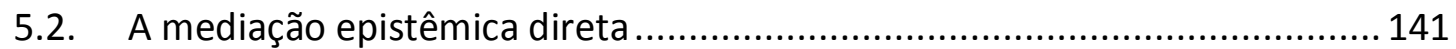

5.2.1. Análise dos discursos presentes na mediação epistêmica direta ................. 144

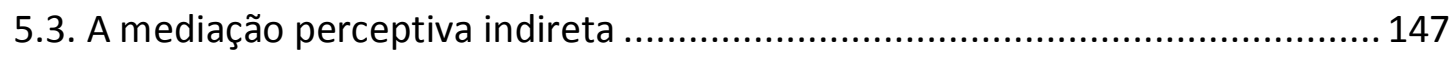

5.3.1. Análise dos discursos presentes na mediação perceptiva indireta................ 153

5.4. A mediação epistêmica complementar ...................................................... 162

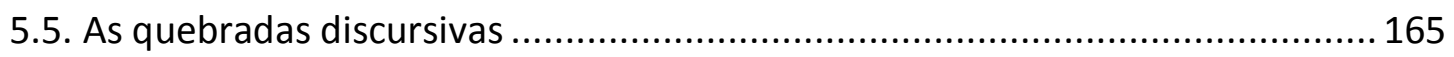

5.5.1 A presença discursiva do discurso do embranquecimento (ND1) .................. 166

5.5.1.1. O caso nodal D119 e outros exemplos: fortes indícios da presença viva do discurso do embranquecimento na amostra.................................................. 172

5.6.1.2. Análise sintética geral e comum dos discursos do Núcleo Discursivo 1 em relação ao quadro de restrição semântica da competência discursiva ampliada.... 175 5.6.2. A presença discursiva do discurso do mulatismo (ND2), o caso nodal D37 e outros exemplos: fortes indícios do discurso do mulatismo na amostra. ............... 176

5.6.2.1. Análise sintética geral e comum dos discursos do Núcleo Discursivo 2 em relação ao quadro de restrição semântica da competência discursiva ampliada.... 181

5.6.3. A presença discursiva do discurso do indianismo e o caso nodal D212 (ND3).

5.6.3.1 Análise sintética geral e comum dos discursos do Núcleo Discursivo 3 em relação ao quadro de restrição semântica da competência discursiva ampliada.... 184

5.6.4. A presença discursiva do discurso da negritude (ND4). 185

5.6.4.1 Análise sintética geral e comum dos discursos do Núcleo Discursivo 4 em relação ao quadro de restrição semântica da competência discursiva ampliada.... 191

5.6.5. A presença do discurso dos povos indígenas (ND5).

5.6.5.1. Análise sintética geral e comum dos discursos do Núcleo Discursivo 5 em relação ao quadro de restrição semântica da competência discursiva ampliada.... 193 
6. Fragmentos discursivos coletivos presentes no corpus

6.1. A imbricação entre os discursos fragmentados dos novíssimos sujeitos sociais e uma instituição de direito coletivo difuso no Brasil: o MSU, Movimento dos Sem Universidade, constituindo-se assim um novíssimo movimento social. .................. 204

6.2. O discurso do MSU ganha a rua, o parlamento, o espaço público .................... 206

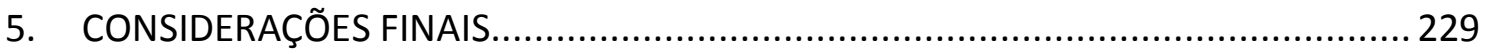

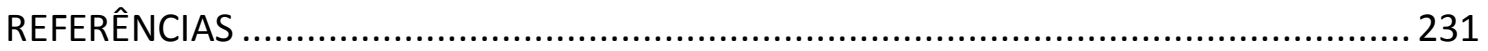

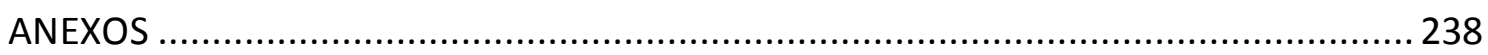




\section{INTRODUÇÃ̃o}

\subsection{Chão da memória}

Entrei no programa de pós-graduação em linguagem e educação na Universidade de São Paulo com um projeto de pesquisa intitulado "junto dos bão a gente fica mió", uma leitura livre e caipira da fala de Riobaldo em Grande Sertão Veredas, de Guimarães Rosa, momento em que ele decide enveredar-se pelo caminho de pedras das letras, sem deixar de ser jagunço.

Minha trajetória de caipira da roça para a cidade grande, para a universidade, foi escrita num livro chamado "Um caipira na Unicamp", que se esconde nas estantes da biblioteca de educação da Universidade de São Paulo e entre dedos calejados do povo da roça de onde vim ${ }^{1}$.

Sou neto de avó negra por parte de pai e de bisavó índia por parte de mãe. Estudei em escola rural pública no meio do mato, depois no grupo escolar rural de Barão de Antonina, depois na Escola Estadual de Primeiro e Segundo Graus Epitácio Pessoa em Itaporanga e fui da primeira turma de concluintes do segundo grau da Escola Estadual de Primeiro e Segundo Graus 31 de Março, na periferia de São José dos

\footnotetext{
${ }^{1}$ Não é raro na lida acadêmica a inscrição de aspectos da trajetória individual, como se vê: "Talvez nesse caso o fato de sair das "classes" que alguns gostam de chamar "modestas" proporcione virtudes não ensinadas pelos manuais de metodologia: a ausência de qualquer desprezo pelas minúcias da empiria, a atenção aos objetos humildes, a recusa das rupturas tonitruantes e dos rompantes espetaculares, o aristocracismo da discrição conducente ao desprezo do brio e do brilho recompensados pela instituição escolar e hoje pelos meios de comunicação". (BOURDIEU, p. 126, 2005). Esses esboços de memória talvez ajudem a reforçar a noção de autoria: “... no meu trabalho, logrei "assumir o ponto de vista do autor", como dizia Flaubert, ou seja, colocar-me em pensamento no lugar que, escritor, pintor, operário ou empregado de escritório, cada um deles ocupava no mundo social: o sentimento de apreender uma obra e uma vida no movimento necessário de sua realização e de estar, portanto, apto a conferir-me uma apropriação ativa de ambas, simpraxia em lugar de simpatia, voltada ela mesma para a criação e ação..." (IDEM, p. 134).
} 
Campos, onde fiz morada no Jardim Petrópolis, rua três, número 101, onde duas famílias de parentes dividiam um meio lote.

Sempre estudei em escola pública, sempre estudei e trabalhei, desde a infância aos seis anos de idade na roça até o colegial noturno na cidade grande. Cedo virei arrimo de família, ao perder meu pai para uma doença de chagas que o vitimou aos quarenta e dois anos de idade.

Sou filho de lavrador e costureira, sou de uma região que ficou conhecida como ramal da fome no Estado de São Paulo, o bairro rural Serra dos Paes, em Barão de Antonina.

Sai do chão da fábrica na Kodak, em São José dos Campos e fui para a universidade estadual de Campinas. Fui um estudante pobre, não matei ninguém, apenas furei a estatística em que tombaram muitos da minha laia.

$\mathrm{Na}$ escola de primeiro grau sempre fui considerado um bom estudante, com boas notas. No colegial, assim como a vida, as notas bagunçaram um pouco. Não me dei por vencido. Na universidade sem eira nem beira, compunha a valiosa liga dos setenta mais pobres que receberam, depois de muita luta, o direito a morar em casas alugadas pela universidade.

Minhas curiosidades intelectuais sempre me fizeram correr atrás do prejuízo. Migrei das exatas por falta de aptidão para trocar lâmpada para as humanidades, na área de economia, curso da escola da Universidade Estadual de Campinas, referenciada em Celso Furtado, Conceição Tavares e cepalinos, diferente das correntes liberais maiorais na área.

Atuei fortemente no movimento estudantil, na lida política geral dos destinos do país com minhas pernas de pau. Numa universidade de elite, nossa laia, em sua maioria oriunda do meio popular, vinculadas já a moradia estudantil da Universidade Estadual de Campinas, decidiu virar o olhar e a ação política para a exclusão da universidade e depois de muitas brigas nasceram os cursinhos populares e as rádios comunitárias. Não tinha celular, nem e-mail, nem o glamour de 1968. Era um movimento estudantil que permanece ainda invisível na história do Brasil.

Naquele microcosmo, estava lá o negro Fran que estudava tecnologia de edifícios, o negro hondurenho Mário, da engenharia elétrica, sua namorada negra Maria, da enfermagem, a negra Adriana, da enfermagem da Unicamp, o negro alto Vagner, da computação, o negro Eduardo, da computação, os negros na Unicamp contavam-se nos dedos das mãos. Os mais pobres da Unicamp e os negros estudavam em sua maioria em 
Limeira, como dizia o Síber, onde se formavam tecnólogos. Essa gente pouca, pobre, negra, junta, varou madrugadas à fio na luta para parir o Cursinho Popular do DCE Unicamp e levariam essas vitórias para o resto de suas vidas. Aquilo foi semeadura nas terras inóspitas da história onde o neoliberalismo no Brasil seviciava e ceifava corações e mentes nas universidades de elite com uma festa atrás da outra.

Quanto à semeadura, foi das boas, entretanto, o que marcaria a história do Brasil, cujos frutos seriam colhidos por outras gerações. Como dizia a camiseta do DCE Unicamp: "Respeite as gerações futuras, defenda a universidade pública."

Nessas ações educativas e políticas, conheci João Vanderlei Geraldi, o gaúcho do IEL (Instituto de Estudos da Linguagem), depois diretor do IEL, homem de fala sagaz e ação política contundente. Acorreu-me em momento de crise política, quando nos fez ver que muitos caras da universidade não queriam ação educativa via cursinho popular coisíssima nenhuma, mas sim, ganhar um dinheirinho nas costas dos pobres e só. Amigo de Paulo Freire, junto a outro amigo comum, o negro Genésio, funcionário da Unicamp que atendia Paulo Freire no balcão da biblioteca da Faculdade de Educação, quando ali Paulo Freire dava aulas, fomos de mala e cuia para a periferia de Campinas, no Jardim Santa Rosa. Ali com ritual de mesa acadêmica, participei com Vanderlei da inauguração do Cursinho Popular Paulo Freire e de uma rádio comunitária. Seguia adiante o itinerário da nova educação popular, os cães que ladrassem.

$\mathrm{Na}$ União Nacional dos Estudantes fui primeiro diretor de universidades públicas e atuei fortemente nos encontros dos Congressos Nacionais de Educação, os CONED's.

Ajudei a espalhar e organizar Brasil afora os cursinhos populares.

Passei a morar em São Paulo, passei em concurso público e comecei a trabalhar como escriturário no Banco do Brasil da Rua Clélia, na Lapa. Graças a isso me graduei em economia, com uma monografia sobre os cursinhos populares. Passei a dar aulas aos finais de semana, de redação, cidadania, história, geografia, matemática nos cursinhos populares nas grandes periferias de São Paulo, como a de Osasco, Guarulhos. Cidade Tiradentes, Cidade Dutra, Campo Limpo, Jandira, Jardim Ângela, Cidade AE Carvalho, Guaianases, Santo Amaro. Essas experiências fragmentárias se uniram num nome dado por Dom Pedro Casaldáliga, o bispo indígena, negro, popular, culto, poliglota do Araguaia: o Movimento dos Sem Universidade, MSU.

O MSU tirou da dor privada e levou para a cena pública a luta pelo direito à universidade no Brasil, com as articulações ensejadas por várias redes sociais e influenciou fortemente no nascimento de políticas de educação, como a criação de um 
Sistema Público de Bolsas de Estudos em Instituições Privadas - o Prouni, e a Lei de Cotas, que contribuíram para a democratização da universidade no Brasil.

As cenas onde se acham as pegadas do MSU estão inscritas na história do Brasil: a luta por isenções das taxas dos vestibulares, a luta pela transformação do presídio do Carandiru em Universidade Pública e Popular, a luta por criação de novas universidades públicas Brasil afora, como a UFABC, a participação nas várias edições do Fórum Social Mundial, a conquista da Universidade da Cidade e da Cidadania de São Paulo na Câmara Municipal de São Paulo em 2001, a ação do Grupo de Trabalho Sobre a Questão Universitária no Município de São Paulo em $2002^{2}$, a luta pela criação de um Sistema Nacional Público de Bolsas de Estudos nas Instituições Privadas e pela regulamentação da Lei Nacional da Filantropia, a conquista do PROUNI, a defesa da criação do Conselho Nacional de Acompanhamento e Controle Social do PROUNI, o apelo pela instalação da Conferência Nacional de Educação, o ENEM como critério de acesso à universidade no Brasil, a conquista, comissão por comissão, da Câmara ao Senado Federal, da Lei de Cotas, em mais de dez anos de lutas no território do Congresso Nacional. Nesses sertões todos, estive presente de corpo e alma. Na maioria das vezes, trajava uma calça jeans azul, uma botina daquelas da roça, uma camiseta amarela escrita MSU em verde como se fosse uma pichação e quase sempre nenhum dinheiro no bolso.

\subsection{Pés na estrada da educação popular}

O escrito, as tintas sobre o papel, em variados casos, despertam a sã curiosidade humana. Torna-se, às vezes, objeto de pesquisas científicas. Foi assim o caso dos registros escritos do interrogatório de um simples moleiro, na inquisição europeia, arquivo interpretado no clássico de Ginzburg (1976).

Pode até ocorrer, mas no geral, não se tropeça em escritos.

Há uma lógica, um relativo ordenamento, algumas questões que orientam as razões, antes de se chegar até os escritos, mesmo que seja um mapa indiciário. Por

\footnotetext{
${ }^{2}$ Conforme descrito na Portaria $135 / 2002$ da Prefeita Municipal, publicada no Diário Oficial do Município de São Paulo.
} 
exemplo, uma ânsia de interpretar o Brasil contemporâneo, sua dinâmica social, as mudanças sociais vistas por intermédio da educação e da linguagem, pode servir de mote de largada para uma busca de arquivos, de documentos, de sentidos em movimento, de discursos escondidos no tempo e suas reverberações, de particularidades relevantes.

Nesses casos, as perguntas mais do que as respostas são bons guias.

Qual dos Brasis? Que mudanças sociais? Que aspecto da educação? Onde se encaixa a linguagem? Discursos de quem, de onde, quando, por que, como? Quais os portos de saída?

Busca-se o Brasil que passou a frequentar as universidades, quando os dados de concluintes do ensino médio indicaram o salto da casa dos milhares para a dos milhões na entrada do novo milênio, os anos 2000. Trata-se de uma considerável massa humana que chega até as universidades, onde muitos homens e mulheres, em suas respectivas famílias, são os primeiros, as primeiras, a fazê-lo. No geral, é de um Brasil urbano que se fala. Territorialmente, são grandes periferias urbanas. É uma economia que extrai sua principal força do setor de serviços, passa por transformações, sob um domínio graúdo de um capitalismo financeirizado onipresente. Trata-se de uma sociedade que convive com desigualdades sociais históricas gritantes e não resolvidas inteiramente, no tocante à distribuição de renda, à posse do dinheiro e da cultura, em termos de gênero e raça, entre as regiões geográficas do país, entre diversos lugares numa mesma cidade grande, ao longo das variadas faixas etárias.

É esse lugar social, historicamente referido, que interessa enquanto "mina de produção verbal". É o processo histórico e os homens e mulheres protagonistas nele envolvidos que interessam. É nos interstícios desse passo longo, da escola até a universidade, que um recorte analítico pode ser vislumbrado.

Portanto, não se trata de um olhar nos marcos da educação formal, para dentro da escola e sua nomenclatura carregada: professores(as), alunos(as), diretores(as), supervisores(as), profissionais da educação, essa cenografia, esse ethos institucional. Ou mesmo para dentro da universidade, com outra carga cenográfica assemelhada e outra institucionalidade própria. Tampouco para a chamada indústria do vestibular e seus rituais monológicos, behavioristas e reprodutores do status quo para o acesso à universidade no Brasil, sejam em grandes cursinhos comerciais, grandes negócios ou via pequenos cursinhos comerciais, igualmente encarados como grandes negócios, empreendimentos educacionais alternativos e que tais, universo coberto por ladainhas 
discursivas assemelhadas: "a aula show", "as turmas imensas", o "professor catedrático", "a cota de aprovação nas melhores carreiras e cursos", "o aluninho, a aluninha", os rituais cenográficos em torno do "bixo" campeão, espécie de orgia pública das heranças, imagem do gozo individual presente no discurso da propaganda desses negócios da educação na grande mídia, hodiernamente financeirizados, em sua maior parte. O centro analítico não está também nas relações no interior destes universos discursivos.

Trata-se de algum lugar entre dois lugares, uma trilha dinâmica no mato alto da exclusão social entre a escola pública e a universidade pública, sem apagar variadas relações e tensões sociais entre estes universos. Logo, se é fora da educação formal, é dentro da educação informal, mais especificamente no campo da educação popular.

Esse campo, na história da educação e da cultura brasileira no século XX, tem grande referência na ação educativa do professor de português Paulo Freire e as experiências dos círculos de cultura que emergiram no nordeste do Brasil, em Pernambuco e no Rio Grande do Norte, nos anos 1940/1950, experiências que abrigavam no microcosmo da ação local a miragem na alteração do macrocosmo educacional, social, onde por meio de objetos do cotidiano de trabalhadores e trabalhadores nordestinos, como "tijolo", a leitura da palavra é a leitura do mundo. Outra referência central é a ação educativa do Teatro Experimental do Negro (TEN), liderado por Abdias do Nascimento, nos anos de 1940/1950 no Rio de Janeiro: até o começo dos anos 1940 quase não havia atores/atrizes negras nos palcos brasileiros. Para realizar seu sonho de ser atriz, Ruth de Souza, uma das fundadoras do TEN, filha de empregada doméstica e de pedreiro, primeiro teve que ler os textos que levaria aos palcos, às telas, como no filme Sinhá Moça, em que brilharia para o mundo em 1953.

No geral, historicamente este campo se concentrou no combate ao analfabetismo, para trazer a cidadania plena, política, para os pobres, negros e negras, os indígenas, milhões de brasileiros excluídos da leitura, da escrita, um longo embate contra o racismo, a desigualdade social, o preconceito social e racial, a humilhação pela origem, cor e riqueza tocada a ferro e fogo por uns das elites, contra outros, do povo, no século XX, onde palavras como "diploma”, “doutor”, "fala difícil”, "branco”, eram senhas para o exercício do mando, do poder e para a garantia da reprodução do status quo. 
No fim do século XX e início do XXI, o direito à universidade ganha assento na ação educativa do campo da educação popular, particularmente nas grandes periferias urbanas.

Essa investigação debruça-se sobre esse episódio - a assunção do direito à universidade na educação popular brasileira, assunto muito pouco pesquisado da educação brasileira.

A educação popular que tem como carro-chefe a luta pelo direito à universidade tem lugar novo na cena nacional. É a emergência na cena pública dos Sem Universidade, dos cursinhos populares ${ }^{3}$, desse clamor popular pelo direito à universidade para os(as) negros(as), os pobres, os(as) indígenas, é a disputa acirrada por novas políticas de educação, cujos passos históricos deixam pegadas e registros na linguagem, no discurso, registros muitas vezes não trazidos à tona, encobertos ainda pela poeira da história, sem arqueologia.

$\mathrm{Na}$ outra ponta, no interdiscurso, se divisa diferentes contra faces da reprodução de uns das elites nas universidades, da reprodução do status quo, portanto.

É preciso reconhecer a radical "diversidade das produções verbais" que emergem nesse campo da educação popular nas periferias brasileiras, escolher uma amostra capaz de abrigar espécimes de matérias-primas com brutal força semiótica, intersemiótica e tenaz representatividade sócio-histórica, como aquela do Hip-Hop e outras musicalidades, das variadas formas de fé religiosa, da mídia massificadora, da propaganda, da polícia, do crime organizado, da política profissional, da dependência química, dos rearranjos familiares, das transformações drásticas no mundo do trabalho, dos novos papéis da mulher, da escola, da vida comunitária, da alegria, da solidariedade, do consumo, muitas vezes de trágicas crônicas.

Contudo, por conveniência de pesquisa, é preciso fazer escolhas simples na direção dos "ritos genéticos" textuais, escolher uma amostra direto das brenhas do real, carregada de sentido do cotidiano oriundo do universo de estudo.

Assim, a alternativa selecionada para essa investigação em linguagem e educação recai sobre um corpus produzido por sujeitos históricos na periferia da cidade de São Paulo. Mais detidamente no Jardim Ângela, em Cidade Tiradentes, em Cidade

\footnotetext{
${ }^{3}$ Cf. "Cursinhos Populares: Democratização do acesso à universidade e inclusão social", de Sérgio José Custódio, Instituto de Economia da Unicamp, Centro de Documentação, 1999.
} 
AE Carvalho (Itaquera) e em Guaianases, lócus de experiências de cursinhos populares, de educação popular do MSU, o Movimento dos Sem Universidade ${ }^{4}$.

Nessas experiências ${ }^{5}$, realizadas no ano de 2003, há o apoio da UNESCO, órgão da ONU para a Educação, que nos anos 1950 patrocinara na Universidade de São Paulo, as pesquisas pioneiras conduzidas por Florestan Fernandes e Roger Bastide, dentre outros, que derrubariam o "mito da democracia racial no Brasil", discurso já sacralizado à época, dentre as elites intelectuais de então, do pernambucano Gilberto Freyre, como se vê no seu livro Casa Grande \& Senzala (FREYRE, 1933).

As experiências de ação educativa popular, aqui selecionadas, do ano de 2003, base documental desse estudo, servem também como uma espécie de potencial grupo de controle, uma amostra da reprodução no tempo dos discursos sobre as relações raciais presentes na sociedade brasileira no geral e, na escola pública e na periferia, em particular, no momento limite das alterações na legislação sobre a educação nacional no tocante às relações raciais, feitas pelo Estado brasileiro.

Ocorre que, antes de 2003, os estudos transversais sobre a história da África na educação básica não eram obrigatórios, o que só passaria a ocorrer com o advento da Lei 10.639, de 9 de janeiro de 2003, tornando obrigatória a temática história e cultura afro-brasileira nas escolas nacionais e acrescentando à Lei de Diretrizes e Bases da Educação Nacional (LDB), Lei 9394/96 os artigos 26-A e seus parágrafos primeiro, segundo, terceiro e os artigos 79-A e 79-B, o que chegaria até o chão das salas de aula apenas nos anos seguintes a 2003.

A Lei de 20/12/1996, "estabelece que compete aos Estados oferecer aos índios uma educação escolar bilíngue, ou seja, simultaneamente em português e línguas indígenas" (ARAUJO: 2006, p. 67). O objetivo da legislação é evidente: " $a$ recuperação de suas memórias históricas, a reafirmação de suas identidades étnicas $e$ a valorização de suas línguas e ciências". (ARAUJO: 2006, p. 67). Mas, seria a Lei 11.645/08, que se ocupa dos estudos dos diferentes povos indígenas brasileiros e suas respectivas culturas que, assim como a Lei 10.639, também fora incorporada à LDB, que de fato, traria obrigatoriamente para as escolas públicas e privadas o estudo dos povos indígenas, para além do fantasioso "19 de abril, dia do índio", rito ainda tragicamente presente hoje em muitas escolas Brasil afora. Assim também, o dia "13 de

\footnotetext{
${ }^{4}$ Em MOEHLECKE (2000), CASTRO (2005), FACEIRA (2009), dentre outros estudos acadêmicos, aparece o termo MSU.

${ }^{5}$ Paulo Freire, em educação popular, considera a ideia de experiência com centralidade, em função da peculiaridade presente em cada ação educativa.
} 
maio" não mais seria uma "dádiva" a ser ensinada nas escolas. Diz o ditado popular: "a cabeça pensa onde os pés pisam”. Às vezes. Pisemos o chão, então. Ora a lei?!

A que remete a palavra "Guaianases"? Aos indígenas, que eram os habitantes do lugar. Quem tem forte presença entre os moradores de Cidade Tiradentes em 2003? Os negros, as negras. Jardim Ângela está mais perto da paz ou da guerra em 2003 ? O que é a paz, o que é a violência? Cidade AE Carvalho quer ir para a universidade em 2003 ou não? Tem muita gente desses lugares nas universidades públicas ou não? Nas universidades privadas? Nesses lugares, em 2003, não há universidade pública por perto. Por que será? Em comparação com outros lugares da cidade, como Moema, no que difere essa presença na universidade pública?

É possível falar num indígena abstrato na cidade grande, se ele está "escondido" lá para as bandas de Grajaú, de Parada de Taipas? É possível esconder o indígena na cidade grande mais do que ele está escondido atrás da estatística da minoria, de nomes como Guaianases, Itaquera, datas como o dezenove de abril, máquinas de costura no bairro que foi berço da produção dos bens de consumos não duráveis no começo dos 1900, o Brás, lugar onde se escondem os rostos indígenas de bolivianos e bolivianas trancafiados em oficinas de costura, muitas vezes oficinas do inferno moderno na Terra nos anos 2000 para imigrantes latino americanos moradores dos fundões da zona leste de São Paulo?

Dá para falar do discurso dos excluídos no Brasil sem falar em algum tom dos povos indígenas, do povo negro, objetiva ou subjetivamente? Em que medida o popular de uma nota só periga camuflar a diferença, engolir e desaparecer com ela do mapa? Haja ouvidos de ouvir e olhos de ver. Por outro lado, não se pode olvidar da miscigenação brasileira, isso seria filosofia vã.

Para melhor compreensão sobre o que significam estas quatro experiências de educação popular do MSU em análise, é preciso voltar um pouco no tempo, olhar para as fotografias daquele tempo.

Os microdados do censo demográfico de 2000 do IBGE permitiram a construção de uma visão mais aprofundada sobre as desigualdades territoriais no município de São Paulo, com a identificação de zonas consideradas nobres, como o bairro de Moema, e outras desprovidas de serviços públicos básicos e com alta concentração de pobres, como o Jardim Ângela.

No geral, o surto populacional que trouxe vastas massas humanas de zonas rurais interioranas, de vários cantos do país, como do nordeste brasileiro, para a conformação 
do espaço geográfico da periferia paulistana está associado diretamente ao processo de industrialização tardia do Brasil, vergonhosa concentração fundiária, desnível gritante do desenvolvimento regional brasileiro, conformação do mercado interno e dependência econômica externa. As grandes migrações percorrem os anos de 1950/1960/1970 e apesar de manterem-se, diminuíram seu peso como tendência populacional a partir dos anos 1980. A industrialização do Brasil de 1930 a 1980 deixou como herança a reprodução da desigualdade social e racial, com abismais diferenças de renda, como revelam o índice de Gini ${ }^{6}$. As massas humanas que construíram a riqueza de São Paulo, não tiveram acolhimento VIP nas periferias, mas vivenciaram uma epopeia humana por sobrevivência de famílias inteiras e sonhos inteiros de fazer corar um solitário Ulisses a procura de sua Penélope.

Foi em 2002, que o Centro de Estudos da Metrópole (CEM), situado no Centro Brasileiro de Análise e Planejamento (CEBRAP), lançou o estudo denominado "Mapa da Vulnerabilidade Social e do déficit de Atenção às Crianças e Adolescentes no Município de São Paulo" (MVS), que foi encomendado pela então Secretaria de Assistência Social (SAS) do município. Considerando que a sobreposição da falta de oferta de serviços públicos básicos, como segurança pública, saúde, educação, saneamento etc. associada a determinadas características demográficas e econômicas dos domicílios pode elevar ou diminuir o nível de vulnerabilidade social das pessoas isto é, a propensão a cair e/ou permanecer na pobreza, ser acometido por doenças, enfrentar situações de desemprego, de insegurança alimentar ou outros fatores que diminuem o bem estar - o estudo mapeou o município de São Paulo considerando como unidade de análise o setor censitário ${ }^{7}$ (unidade que agrega em torno de 250 a 300 domicílios e que são visitados por um recenseador) e, em segundo estágio, os distritos ${ }^{8}$, que são divisões administrativas municipais.

O MVS considerou que um distrito que concentrasse maior número de setores censitários em piores condições (com maiores carências de serviços públicos e com maior presença de famílias prevalentemente jovens, com baixa renda, crianças pequenas e baixa escolaridade do responsável) era um distrito mais vulnerável (atribuindo ao pior deles o valor negativo de -1 para o Índice de Vulnerabilidade Social, IVS), enquanto que um distrito com maior proporção de setores censitários em melhores condições

\footnotetext{
${ }^{6}$ Varia de 0 a 1 e mede a desigualdade de renda numa sociedade, mais próximo de zero, mais desigual.

7 À época do censo demográfico de 2000, o município de São Paulo contabilizou 13.193 setores censitários.

${ }^{8}$ Quando da elaboração do MVS, São Paulo tinha 96 distritos.
} 
(com a oferta de serviços públicos e maior presença de famílias com maiores rendimentos, alta escolaridade e poucas crianças) seria considerado sem privação, e, portanto teria baixíssima vulnerabilidade social, e ao melhor deles foi dado o valor positivo de +1 para o IVS.

Deste modo, percebe-se que o IVS possui uma escala de -1 a +1 , variando, portanto duas unidades de medida, e que quanto mais positivo, melhor é a situação geral daquele distrito, e quanto mais negativo, piores são as condições de vida naquela região.

O MVS pintou com tonalidades diferentes cada setor censitário do município de São Paulo, em função do seu valor de IVS, de modo que ele destaca a distribuição geográfica da desigualdade social no município de São Paulo, conforme pode ser observado na ilustração a seguir:

Figura 1 - Mapa da Vulnerabilidade Social - Município de São Paulo - 2000

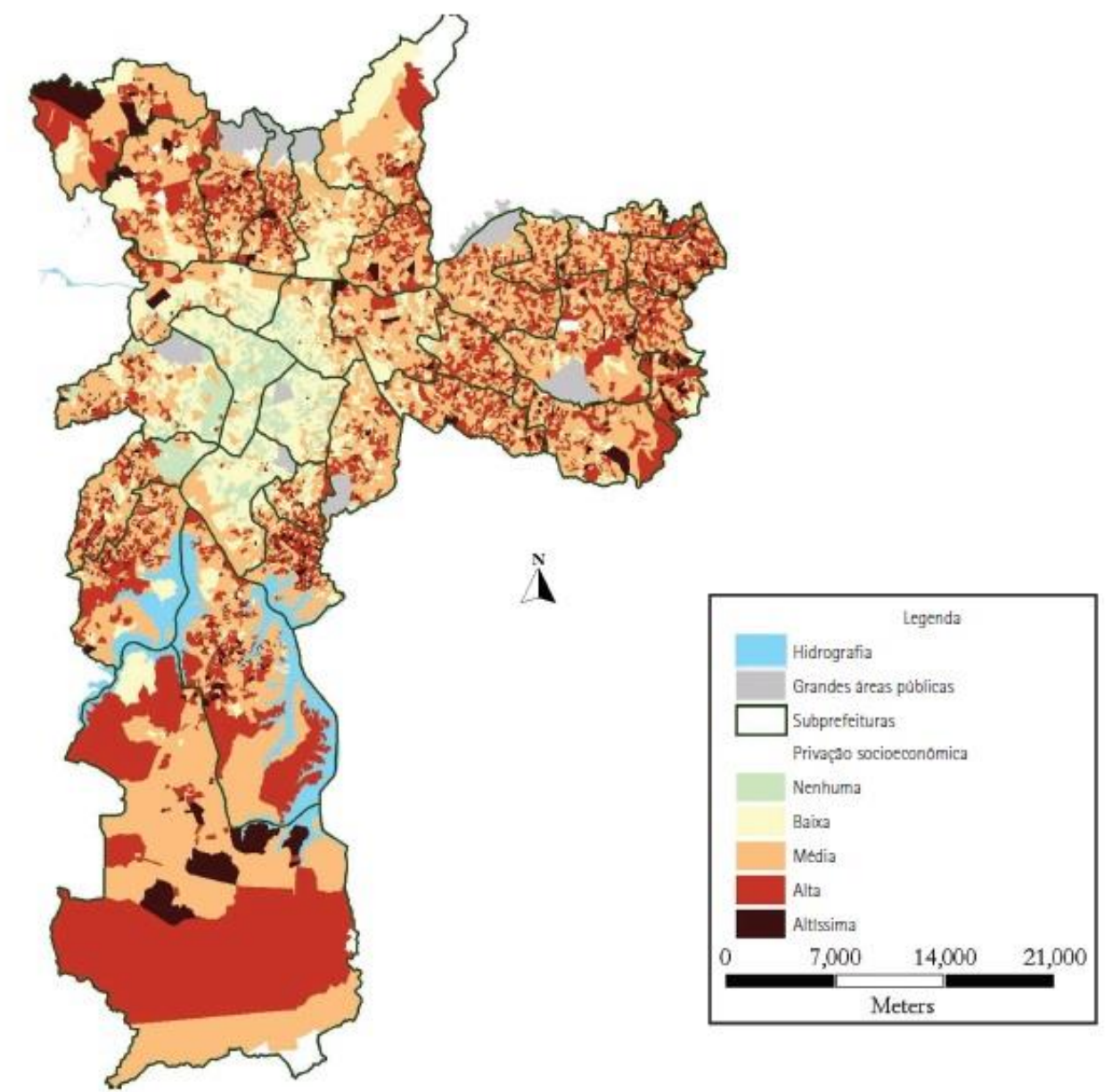

Fonte: Censo Demográfico, IBGE, 2000 e Centro de Estudos da Metrópole, 2002.

Tendo em vista a temporalidade do MVS, construído a partir dos dados do censo de 2000, e que o corpus analisado nesta dissertação foi produzido em 2003 por integrantes dos projetos de educação popular desenvolvidos pelo MSU em quatro 
regiões da periferia do município de São Paulo, torna-se relevante situar tais regiões no contexto municipal daquela época.

Segundo o MVS, o Jardim Ângela, localizado na zona sudoeste de São Paulo, era o pior distrito do município, com um IVS igual a menos um (-1). Este distrito contava em 2000 com 243.845 habitantes distribuídos em 275 setores censitários, dos quais 195 eram considerados em situação de alta vulnerabilidade social (23 dos quais, em altíssima vulnerabilidade social) e nenhum deles era considerado sem privação alguma.

A segunda localidade onde se encontravam ações de educação popular do MSU era o distrito de Cidade Tiradentes, na zona leste do município. Com 190.555 habitantes e 243 setores censitários, dos quais 119 encontravam-se em situação de alta vulnerabilidade social, seu IVS foi calculado em -0,90.

Já o distrito de Guaianases tinha seu IVS igual a -0,76, contava com 98.137 habitantes, em 122 setores censitários, dos quais 63 estavam em alta vulnerabilidade social.

Por fim, o MSU tinha projeto de educação popular no distrito de Itaquera, considerado o menos pior dos quatro, seu IVS era igual a -0,55. Itaquera contabilizava 201.178 habitantes, que ocupavam 260 setores censitários e, destes, 89 foram tidos como em condições de alta vulnerabilidade social.

Deste modo, fica evidente que as quatro experiências de educação popular do MSU que produziram os documentos, o corpus de análise localizavam-se em áreas cujas condições de vida eram bastante precárias, senão as piores do município, o que instiga ainda mais a realização deste trabalho dissertativo.

Ademais, reforçam essa convicção os dados do Censo Demográfico de 2000, que revelam outra dimensão marcante da sociedade brasileira, e também de São Paulo: a desigualdade social tem cor. Ser negro (preto ou pardo, segundo a classificação do IBGE) no país é condição suficiente para que a probabilidade de se ter uma qualidade de vida inferior à da média da população branca seja maior.

A tabela ${ }^{9}$ a seguir mostra os dados da população por raça/cor nos cinco distritos mencionados nesta seção, ou seja, além dos locais dos projetos de educação popular, incluiu-se o distrito de Moema, para melhor contextualização do locus de análise, haja

\footnotetext{
9 Dados disponíveis em: <http://www.prefeitura.sp.gov.br/cidade/secretarias/saude/epidemiologia_e_informacao/informacoes_soci oambientais/index.php?p=8452\#02>. Acesso em: 01 de agosto de 2014.
} 
vista que a comparação com outros distritos permite uma compreensão maior do próprio corpus estudado.

Destaca-se na tabela a concentração de brancos (superior a 90\%) na região de Moema que foi considerado o distrito melhor classificado segundo o IVS e a de negros (considerando-se pretos mais pardos), em torno de 50\% no Jardim Ângela, em Cidade Tiradentes e em Guaianases. O Jardim Ângela detinha então o pior indicador de vulnerabilidade social. Enquanto o Jardim Ângela, Itaquera e Guaianases concentram praticamente a mesma quantidade de pretos, Cidade Tiradentes, por seu turno, concentra o maior número de pretos, quase o dobro em relação a esses outros lugares. Cidade Tiradentes também é o lugar geográfico mais distante em relação ao centro. 
Tabela 1 - População por raça ou cor, segundo o Distrito Administrativo - Município de São Paulo - 2000

\begin{tabular}{l|ccccccc|c}
\hline \multirow{2}{*}{ Distrito Administrativo } & \multicolumn{7}{c|}{ População } & \multirow{2}{*}{ IVS } \\
\cline { 2 - 7 } & Branca & Amarela & Parda & Preta & Indígena & Ignorado & \\
\hline Jardim Ângela & $47,2 \%$ & $0,3 \%$ & $45,1 \%$ & $6,3 \%$ & $0,2 \%$ & $0,9 \%$ & $-1,00$ \\
Cidade Tiradentes & $49,4 \%$ & $0,1 \%$ & $38,4 \%$ & $11,4 \%$ & $0,2 \%$ & $0,4 \%$ & $-0,90$ \\
Guaianases & $51,8 \%$ & $0,3 \%$ & $40,3 \%$ & $7,0 \%$ & $0,1 \%$ & $0,5 \%$ & $-0,76$ \\
Itaquera & $60,2 \%$ & $1,2 \%$ & $30,5 \%$ & $7,3 \%$ & $0,2 \%$ & $0,6 \%$ & $-0,55$ \\
Moema & $91,9 \%$ & $2,8 \%$ & $3,8 \%$ & $0,9 \%$ & $0,1 \%$ & $0,5 \%$ & $+1,00$ \\
\hline São Paulo & $67,0 \%$ & $2,0 \%$ & $25,0 \%$ & $5,1 \%$ & $0,2 \%$ & $0,8 \%$ & ---- \\
\hline
\end{tabular}

Fonte: Amostra do Censo Demográfico do IBGE, 2000.

Por isso, é preciso divisar no cenário brasileiro o campo educacional (BOURDIEU, 1983) e ir além.

Muito além dos muros das escolas e universidades, seus cadeados e senhas, grades e chaves. É preciso pisar o chão, sentir o cheiro, ver os rostos, “prosear”, ouvir as vozes que brotam em terras férteis nos limites do campo: suas beiradas, suas bordas, fronteiras, suas pluralidades. Habitar suas contradições, maiores ou menores. Chorar e rir com e "ir entre os que vivem".

É nessas margens que se aninha a educação popular, numa concepção plural e com múltiplas dimensões: multicultural, territorial, racial, de gênero, por exemplo, numa leitura que abriga divergências, fazeres discursivos distintos, tensões discursivas óbvias. Será possível existir espaço para negociações discursivas, convergências nesse horizonte?

Não como enfeite retórico, mas como necessidade de juntar, articular, unir para fortalecer a posição no campo educacional brasileiro, sair do "mezzo" marginal, ou para ser mesmo considerado no campo e disputar políticas de educação com isso, com outros discursos que povoam também o campo, muitos deles dominantes, de perfil hegemônico, neutralizadores das vozes dos outros sociais no largo passo da história. Será possível?

Essa tarefa não é trivial, mas indica desafios colocados para esse estudo.

Logo, tratam-se de muitos passos, um deles busca identificar e caracterizar essa semeadura discursiva no chão brasileiro feita por muitas mãos calejadas, as muitas sementes preservadas de geração para geração, de há muito tempo, pois não são apenas os discursos advindos do "berço esplêndido", nem dos que "dormem eternamente" e acordam de repente. 
Outrora, como hoje, esses discursos sobrevivem como bambus que "vergam, mas não quebram" pelo efeito dos ventos fortes dos discursos dominantes, que sustentam a reprodução da desigualdade na sociedade brasileira.

Cada discurso, caso muitos haja, tem sua razão. "Não é couve, que a enxurrada discursiva mais forte já leva embora, mas madeira que cupim não rói”, mesmo que perdidos na floresta dos discursos ditos invisíveis.

Seus voos, se baixos ou altos, podem chamar a atenção dos mores do campo educacional, das principais forças sociais, instituições. Seus cantos isolados podem virar cantoria. Suas falas, discursos de tons elevados por direitos historicamente negados. As dores privadas desses sujeitos históricos, desses agentes, transmutarem-se em clamores populares, públicos. O combate é duro, à luz do dia, à luz de vela, até na lua minguante: contra a exclusão da educação no Brasil.

Nessas margens, antes das leis de 2003 e de 2008 "pegarem”, é que caminha esta dissertação. Busca-se enxergar e captar os discursos por direito à educação no Brasil, em particular, pelo direito à universidade.

Onde estão esses discursos? Em qual baú? É só tinta sobre papel branco ou tem mais tesouros? Com que caixa de ferramentas teóricas se abre o baú? Da caixa de ferramentas teóricas o que dá pra usar de pronto? Algum serrote, martelo, pá de pedreiro? Algum prumo?

O prumo aqui é a análise do discurso. O objeto são os textos específicos do corpus e não só. As ferramentas também advêm da análise do discurso, e elas irão, paripassu, surgindo, no caminho dessa dissertação, não isoladamente, mas como opções teóricas consistentes, encadeadas.

Feito imã, quem as convoca é o que está dentro do baú, são os textos, moradas ou não dos sujeitos. Para Geraldi ([1991] 2013, p. 137 - grifo nosso),

$$
\begin{aligned}
& \text { por mais ingênuo que possa parecer, para produzir um texto (em qualquer } \\
& \text { modalidade) é preciso que: a) se tenha o que dizer; b) se tenha uma razão } \\
& \text { para dizer o que se tem a dizer; c) se tenha para quem dizer o que se tem a } \\
& \text { dizer; d) o locutor se constitua como tal, enquanto sujeito que diz o que } \\
& \text { diz para quem diz (ou, na imagem wittegensteiniana, seja um jogador no } \\
& \text { jogo); e) se escolham as estratégias para realizar (a), (b), (c) e (d). }
\end{aligned}
$$

Assim, por intermédio da análise do discurso, dado que há um jogo pela direito à universidade no Brasil (de há muito) pretende-se perscrutar o surgimento de sujeitos do discurso. 
O baú ou o corpus, base dos textos, dos documentos, é composto por um conjunto de textos argumentativos que discutem, se posicionam ou não, frente a diferentes opções de políticas de acesso à universidade no Brasil.

Esse posicionamento é intermediado diretamente por uma coletânea de textos de referência, que são excertos de diferentes discursos presentes no debate público brasileiro em 2003, conforme registros escritos retirados dos meios de comunicação de massa no Brasil.

Como uma espécie de pano de fundo desse cenário discursivo ou mesmo como cenas paralelas, o baú também guarda um questionário sociocultural com perguntas e respostas individuais que, no geral, abordam aspectos relevantes que informam mais sobre os agentes, principalmente no quesito disposições e capital cultural, importantes para a apreensão e entendimento da cena de enunciação.

Muitas perguntas pertinentes poderiam desafiar esse corpus. Nessa investigação, entretanto, opta-se por perscrutar indícios (à moda do paradigma indiciário), rumores, os fragmentos da emergência do discurso dos Sem Universidade na educação brasileira.

De volta à caixa de ferramentas teóricas necessárias para a empreitada investigativa, importa fazer diferenciações presentes na abordagem científica da Análise do Discurso (AD):

a $\mathrm{AD}$ não funciona como (supomos que funciona) a física ou mesmo a gramática gerativa, ou seja, a partir da última versão da teoria, porque ela teria superado as anteriores. Isso significa que não há propriamente, no campo da AD questões vencidas. (POSSENTI, 2011, p. 153-154),

Ou seja, não se trata de ferramentas ideais, absolutas ou advindas do forno da última tecnologia inventada. A noção de caixa de ferramentas teóricas é uma metáfora onde as próprias ferramentas precisam ser relativizadas em sua serventia e nos sentidos de seu uso.

A história conta na AD. O que significa isso? Que o baú tem uma história, ele guarda relação com a história e suas tensões. O corpus selecionado não existe ex nihil nem os discursos porventura nele presentes.

São duas as ferramentas teóricas que se apresentam de imediato como "batedoras" na abertura dessa investigação: sujeito do discurso e a noção de que " $a A D$ pretende dar conta do fato de que algo sempre fala antes e alhures" (POSSENTI, 2011, p. 155), o que deságua na categoria interdiscurso. 
O estatuto dessas ferramentas teóricas será aprofundado adiante. Outras mais, mesmo de outros campos de saberes, por importância e pertinência, poderão ser mobilizadas no correr da dissertação, caso estritamente necessárias.

1.3.

No meio do caminho a linguagem nas relações raciais no

\section{Brasil}

Os sons produzem ruídos, ecos. Isso se percebe de palavras, de falas, de mímicas, também o tato e o cheiro tem lá seus ecos próprios. Até o silêncio - "o mais intenso dos acordes musicais"10 - produz eco. Na periferia, ensina a sabedoria que, "quem falar morre", em dadas circunstâncias. Assim o silêncio anda de boca em boca, ecoa a violência.

Há que se notar que essa noção tem relação direta com a educação popular, isso se dá muito em função dos saberes populares, da cultura oral, da memória coletiva, algo arraigado nos costumes. Por exemplo, eco pode dizer respeito a ditados populares, que perpassam o tempo, diferentes lugares. Nesse sentido,

para A. Berrendonner $(1982,199)$, o provérbio deve ser classificado entre os fenômenos de "menção", de enunciações ditas sobre outra enunciação. Ele se caracteriza pelo fato de que "a enunciação relatada E0 é aí apresentada como um acontecimento da enunciação meta (=mencionante), E1". Pode-se aqui falar de enunciação-eco, na medida em que o enunciador do provérbio dá sua asserção como uma imitação, o eco, a retomada de um número ilimitado de enunciações anteriores desse mesmo provérbio. Em um quadro polifônico, observar-se-á que o locutor do provérbio é também seu enunciador, isto é, assume-o pessoalmente, mas o faz apagando-se atrás de outro enunciador "on", que é o verdadeiro fiador da verdade do provérbio (1982, p. 207).

Esse on que representa a opinião comum, a "sabedoria popular", é, no caso presente, um "agente verificador", uma instância suscetível de validar uma proposição; ele constitui o suporte da "on-verdade" do provérbio (BERRENDONNER, 1982, p. 40). Em uma ótica polifônica, esse on é uma personagem que participa da comunicação, validando uma primeira asserção E0, cuja verdade é pressuposta por uma segunda, E1. (MAINGUENEAU, 2010, p.p. 172-173 - grifos do autor).

Fica patente a importância da noção de eco, que poderá ou não aparecer no corpus. Ou seja, o silêncio que ecoa na periferia em certos casos extremos, pode valer

10 "Visão de Graciliano Ramos”, Otto Maria-Carpeaux, 1942. 
ou não. Na dúvida, quem se arrisca entre a vida e a morte? Há muitos ecos no tempo histórico brasileiro, em variadas dimensões.

O burburinho das vozes atravessa o ar, os corpos, paredes, textos, romances e o discurso, que permanece nos dias. Une a subjetividade do sujeito ao olhar que enxerga ao redor de si, "deixa as orelhas em pé”, enfim, envolve todos os sentidos.

Ecoa também nos tempos, por uma plurissemioticidade (sons, textos, falas, cinema, literatura, quadros, esculturas, fotografia, gravura, caricatura, internet, documentos oficiais, livros, teatro etc.) a dor, o barulho do chicote nas costas do africano sob o domínio da escravização ${ }^{11}$ que apanha no pelourinho, na praça pública, mesmo depois da lei de 7 de novembro de 1831, que proibiu a importação de escravizados da África para o Brasil. Fato não esgotado da história brasileira, pois a despeito do ato legal proibitivo, vieram escravizados para o Brasil mais cerca de 750 mil africanos e africanas, apesar da lei, repita-se, donde o reforço do mote "para inglês ver”. Como mostra Chalhoub (2012, p. 84), a língua distinguia os escravizados que já estavam no Brasil dos que vieram depois da lei que proibiu o tráfico em 1831:

o artigo nono do decreto de 12 de abril de 1832, que regulamentou a lei de 1831, mandava que a autoridade, ao investigar se um determinado africano era ou não "boçal", examinasse logo "se entende a língua brasileira". Além disso, devia-se saber havia quanto tempo estava no país, em que barco chegara, onde desembarcar, por quais lugares passara.

No meio do caminho do Brasil, no meio do caminho do escravizado, da escravizada africana, mesmo indígena, estava a língua. A língua contava, como conta até os dias de hoje, por exemplo, para o acesso às universidades no Brasil.

O domínio ou não da língua portuguesa falada no Brasil perante o interrogatório policial feito pelo Estado, exclusivamente para corpos negros, indígenas também, podia levar à escravização ou à 'liberdade' do negro, da negra, dos africanos no geral, mesmo que crianças, ainda que estivessem na condição de forro, pois a cor da pele já o punha sob a imediata suspeita policial. O negro no Brasil pisava no fio desta navalha ao pisar em terra brasileira, com a polícia do Império no seu encalço:

por ora, o que interessa no laudo do "Doutor curador dos africanos livres" é o modo como gira quase inteiramente em torno das aquisições linguísticas do congo Luiz. Há uma espécie de índice de evolução no domínio do idioma,

\footnotetext{
${ }^{11}$ A palavra escravização, ao invés de escravidão, indica uma ação, o que pressupõe um agente. Isso serve para deslocar qualquer naturalização dessa condição: ninguém nasce "escravo" como se fosse predestinado para, mas é escravizado, em função de condições históricas e sociais. Vários autores utilizam "escravização", opção dessa escrita, como aparece em trecho de Euclides da Cunha: "Enquanto este, de traçado incomparavelmente mais próprio à penetração colonizadora, se tornou o caminho predileto dos sertanistas visando sobretudo a escravização...”(CUNHA, E., [1902] 2002, p. 184).
} 
para a superação do estado de "boçalidade", como pressuposto do documento. Assim, ao chegar, o preto era mesmo "boçal", pois "nada falava do idioma português". O interrogatório mais recente fora realizado parte em português, parte em língua africana, "para ser entendido em alguns pontos de suas respostas". No entanto, Luiz já conhecia "algumas palavras de nossa língua", conseguia pronunciá-las de maneira a se fazer entender. Havia adquirido essas habilidades entre 4 de novembro de 1837, quando aparecera na chácara de dona Thereza, e 23 de abril de 1839, data do interrogatório; se o africano tivesse ingressado no país legalmente, ou seja, antes de 7 de novembro de 1831, supõe-se que "devia necessariamente conhecer hoje a maior parte das palavras portuguesas". Em suma, as informações sobre o processo de domínio do idioma pelo congo Luiz constituem a prova principal de que ingressara no país após a proibição do tráfico. De modo acessório, importou saber que Luiz desembarcara num lugar "todo em mato" e que caminhara noite adentro "sempre acompanhado com homens armados", circunstâncias que confirmavam o caráter clandestino de sua chegada. (CHALHOUB, 2012, p. 90).

O chão pisado por pés descalços, dos escravizados africanos e das escravizadas africanas - que eram proibidos de usar sapatos na década de 1830 e nos anos seguintes, guardou essas pegadas na história do Brasil.

A linguagem aparece como instrumento decisivo do poder de polícia, ela serve ao poder e o poder dela se serve. Se boçal ou ladino ${ }^{12}$, se escravizado ou liberto sob uma dura vigia e suspeita infinita, é com este veredicto linguístico, feito somente sobre os corpos negros, que o Estado os prendia para uma posterior deportação à África ou os entregava nas mãos do senhor-de-escravo ou os mantinha livres, se forros confirmados, sem, contudo, nunca exaurir a suspeita em função das circunstâncias, pois a cor da pele era a senha da suspeição, dela não se livrava o negro, mesmo que liberto. Ou seja, todo negro, toda negra, ainda que forros, são primeiro suspeitos ${ }^{13}$ de fuga da condição de escravizados, depois de comprovados por um texto, um papel escrito, além dos pés calçados, é que poderiam ser considerados livres de fato. É essa semeadura da dor que levará, longe nos tempos, seus ruídos. Mesmo o silêncio far-se-á eco, discurso.

Sim, pois a produção de silêncio sobre 1831 continuou após a lei de 1850 , num labor constante, vigilante, que faz parte talvez da seiva que alimenta até hoje, no "caráter nacional", a mania de tergiversar sobre o problema racial no país. (CHALHOUB, 2012, p. 140).

Desde este ponto de partida, qual seja, os discursos que brotaram no quadro social da escravização ilegal de cerca de 750 mil africanos após a proibição do tráfico em 1831 pela ordem jurídica da nação que se formava, inicia-se longa jornada até o

\footnotetext{
${ }^{12} \mathrm{O}$ adjetivo "ladino" se aplicava ao africano que já falava português e era afeito aos costumes do Brasil, por oposição ao africano recém-chegado, dito "boçal". (CUNHA, C., 2012, p. 98).

${ }_{13}$ Isso provavelmente resolvia para a polícia o embaraço de ter de averiguar a condição de livre ou escravo, e certamente reforçava no liberto a consciência da precariedade de sua condição. Consciência que ele claramente tinha: um preto, até prova em contrário, era um escravo. Talvez por isso muitos forros tivessem ido se estabelecer em quilombos. (CUNHA, C., 2012, p. 95).
} 
Brasil do começo do século XXI, onde os discursos raciais continuam servindo para negar direitos aos pretos, pardos e indígenas, como o direito à universidade pública paulista.

Situação antiga e atual, paradoxalmente, quando se problematiza a questão da homogeneidade da sociedade brasileira. Nesse sentido, é pertinente a contribuição de Manuela Carneiro da Cunha (2012, p. 108),

\begin{abstract}
mas que homogeneidade era essa? José Bonifácio a pensa sob duas espécies concomitantes: uma homogeneidade "physica e civil". O que entendia por homogeneidade civil é explícito: um país dividido em senhores e escravos era um país instável, desprovido de pacto social. Somente um país de livres poderia constituir uma nação homogênea, "fundada na Moral e na Razão". Essa homogeneidade de condição era a garantia da viabilidade do Estado: "como poderá haver uma Constituição liberal e duradoura em um paiz continuamente habitado por uma multidão immensa de escravos brutaes e inimigos?"
\end{abstract}

Paradoxalmente, a homogeneidade social era perigosa demais para o jogo de poder das elites no século XIX. A minoria branca da elite que punha seus pupilos nas universidades daqui feito faculdades ou em Coimbra, temia a unidade da maioria diversa, escravizada. Um medo animador de gigantesca violência.

As premissas inspiradoras da lei do novo país no continente americano, o Brasil, são tomadas de empréstimo da revolução burguesa americana e sua constituição de 1776, da revolução francesa de 1789, do Congresso de Viena da restauração monárquica de 1815, e, do medo dos acontecimentos provocados pelos pretos de São Domingos na América Central em 1798 (onde os franceses recuaram de seus pendores de igualdade, fraternidade e liberdade a troco de uma boa colônia provedora). ${ }^{14}$ De forma que, o Brasil nasce, em síntese, sob um liberalismo de fachada, com escravização negra e mesmo indígena, submissão da Igreja ao Estado e concentração do poder nas mãos de um imperador, como ensinou a professora Emília Viotti da Costa (2010, p. 134; 144),

atribuindo a instabilidade dos demais países latino-americanos à forma republicana de governo, as classes dominantes brasileiras adotaram, em 1822, uma monarquia constitucional com a qual esperavam conseguir unidade e estabilidade política. Atemorizados pelos espectros da Revolução Francesa e da revolta dos escravos no Haiti, desconfiavam tanto do absolutismo monárquico quanto dos levantes populares revolucionários e estavam decididos a restringir o poder do imperador e a manter o povo sob controle. Para levar a cabo seu projeto encontraram sua principal fonte de inspiração no liberalismo europeu.

O liberalismo brasileiro, no entanto, só pode ser entendido com referência à realidade brasileira. Os liberais brasileiros importaram princípios e fórmulas políticas, mas as ajustaram às suas próprias necessidades. Considerando que as mesmas palavras podem ter significados diferentes em contextos distintos,

14 “Onda Negra, Medo Branco”, (Azevedo, Célia Maria Marinho, 2008, ANNABLUME). 
devemos ir além de uma análise formal do discurso liberal e relacionar a retórica com a prática liberal, de modo que possamos definir a especificidade do brasileiro. Em outras palavras, é preciso desconstruir o discurso liberal. [...]

Ficavam excluídos do conceito de cidadão escravos, índios e mulheres. Adotou-se a eleição indireta.

As elites políticas dão o tom do que cabe e do descabido na nova nação sob os auspícios da violência extremada, do comando de vida e morte de uns sobre os corpos de Outros, com distorções outras e variadas, que o tempo futuro se encarregará ou não de também ecoar, reproduzir-se,

seja como for, o que José Bonifácio silencia será, no entanto dito em alto e bom som pelos antiescravistas das décadas de 1830 e 1840: a homogeneidade necessária à existência da nação passava pela exclusão dos negros. Uma nação de livres sim, mas de livres brancos (CUNHA, C., 2012, p. 109).

A linguagem das teorizações verticais, fabulações, reflexões, interpretações ou anseios sobre as realidades sociais, à moto de dogmas, pode bem valer-se da ocasião, da tradição, do conveniente, enxergar ou cegar sobre o outro, a outra, as heterogeneidades do real específico, do social,

de modo significativo, a questão continua a ser tratada em duas linguagens que se querem paralelas, mas que costumam se fundir: uma "política", a outra "natural", em parte talvez porque o político se pensava fundado na natureza. A nação fisicamente homogênea era o sustentáculo e a precondição da nação civilmente homogênea. Ora, essa nação almejada, necessariamente homogênea, poderia ser formada a partir de grupos sociais historicamente antagônicos e naturalmente heterogêneos? "Convirá", escreve Burlamaqui, "que fique no paiz huma tão grande população de libertos, de raça absolutamente diversa da que a dominou? Poderá prosperar e mesmo existir huma Nação, composta de raças estranhas e que de nenhuma sorte podem ter ligação? (CUNHA, C., 2012, p. 109).

Essa percepção da autora alumia sombras discursivas presentes na educação nacional, como é o caso do discurso sobre o "indianismo" na literatura pátria, visto, por exemplo, na obra do autor escravocrata José de Alencar, muitas vezes incensado acriticamente nos meios escolares, cuja senha para uma leitura e interpretação crítica é justamente seu elo com um projeto nacional de homogeneização:

é de amplo conhecimento que a pretensão a uma continuidade genealógica com os indígenas foi o mecanismo simbólico de maior força nos anos que se seguiram à independência. $\mathrm{O}$ índio passou a representar o Brasil como um todo e a população brasileira passou a enfatizar raízes - sobretudo imaginárias - indígenas. Nas caricaturas da primeira metade do século XIX, nos monumentos públicos celebrando a Independência, era o índio que simbolizava a nova nação (CUNHA, C., 2012, p. 107).

O negro, a negra, o indígena, a indígena, a mulher, como se vê, inscrevem-se na história brasileira como o outro, a outra, social, real, ocupando espaço na língua e ecoando nos textos, no tempo. Suas presenças nos discursos problematizam a 
homogeneização e abrem alas para a heterogeneidade presente nas matrizes discursivas sobre as relações raciais no Brasil, relações de gênero, relações sociais, desde seu nascimento enquanto nação. Esse "fato linguístico" visto logo acima, esse "equívoco" desnudado por Manuela Carneiro da Cunha, mostra-se como "fato estrutural implicado pela ordem do simbólico", onde o discurso "envolvente" sobre os índios fincava-se na necessidade da posse de todo o território brasileiro após a Independência, daí ser útil uma "genealogia" direta com os primeiros donos das terras brasileiras, ainda que como "caricatura", para a legitimidade do poder em curso sobre um vastíssimo território, do Oiapoque ao Chuí.

Em Memórias Póstumas de Bras Cubas, por exemplo, ocorre um "jogo com o outro" no discurso, que opera no espaço do social, do "semidesvelado", do "sugerido".

A publicação é feita num jornal carioca nos anos 1860, que era o suporte do folhetim, do romance que toma corpo aos pedaços como instituição discursiva no Brasil.

Se tomado como registro de uma crônica de costumes, serve para revelar os discursos e as práticas sociais que dominam o cotidiano e marcam os corpos, impregnando-os. Ainda, é carregado adiante pelas memórias coletivas de leitores.

No capítulo curto "O menino é o pai do homem” esse jogo aparece,

Prudêncio, um moleque de casa, era o meu cavalo de todos os dias; punha as mãos no chão, recebia um cordel nos queixos, a guisa de freio, eu trepava-lhe ao dorso, com uma varinha na mão, fustigava-o, dava mil voltas a um e outro lado, e ele obedecia, - algumas vezes gemendo, - mas obedecia sem dizer palavra, ou, quando muito, um - "ai, nhonhô!" - ao que eu retorquia: - "Cala a boca, besta!” (ASSIS, [1881] 1997, p. 21).

Prudêncio, o moleque, era o escravizado negro, criança ainda já era o Outro, talhado para obedecer. O protagonista, o branco, o sinhozinho em formação, o menino, já era o Um, o escolhido para mandar. Prudêncio não vai para a universidade, ao passo que "Nhonhô", vira doutor em Coimbra, moda da elite brasileira então: Uns nascem para mandar, Outros para obedecer.

Mergulho mais profundo, de curto fôlego, talvez não seja demais. Por exemplo, o discurso dos jesuítas de outrora, antes da independência do Brasil, aparenta-se como uma terrível metáfora discursiva alimentada pela Bíblia e dirigida aos africanos escravizados no Brasil. Há vários tons. 
Pregações como a do Padre Vieira ${ }^{15}$ nos seiscentos justificam o status quo daquele tempo, comparando o sofrimento dos escravizados nas terras da cana-de-açúcar ao calvário de Jesus Cristo nas mãos dos romanos. A expectativa de vida no trabalho escravizado do engenho, "o inferno na terra", em média, era de oito anos de vida. Depois da morte, o paraíso!

Outro tom mais alto do discurso dos jesuítas, também bebeu da Bíblia, desta feita do Antigo Testamento, como resgata o professor Andreas Hofbauer,

\begin{abstract}
o jesuíta Jorge Benci (1650-1708), nascido em Rimini, dedicou um livro Economia cristã dos senhores no governo dos escravos - à reflexão teológica sobre os fundamentos e a moralidade da sociedade escravista. Fiel à Bíblia, Benci atribui o surgimento da escravidão ao pecado de HAM: [...] visto que a servidão e cativeiro teve sua primeira origem do ludíbrio, que fez Cam, da desnudez de Noé seu pai. Sabido é que dormindo este Patriarca com menos decência descoberto, vendo Cam, e escarnecendo desta desnudez, a foi publicar logo a seus irmãos; e em castigo deste abominável atrevimento foi amaldiçoado do Pai toda a sua descendência, que no sentir de muitos é a mesma geração de pretos que nos servem; e aprovando Deus esta maldição, foi condenada à escravidão e cativeiro (HOFBAUER, 2006, p. 169).
\end{abstract}

Assim, são evidentes os alicerces históricos fincados no chão brasileiro dos discursos das relações raciais.

\title{
1.4. $\quad$ No ar do Brasil uma artimanha discursiva dominante
}

Gilberto Freyre buscou a fórceps cultural o amálgama na sociedade brasileira, o unionismo entre as raças, lapidação discursiva ímpar, bebida, dentre outros, nos estudos pioneiros de Rudiger Bilden, da Universidade de Columbia, nos anos 1920/1930 e cravados em corpos, almas e papel no já citado Casa Grande \& Senzala, lançado em 1933, dentre uma miríade de textos herdeiros deste, que dá o tom.

Uma construção discursiva estrondosa sobre o real nacional, de avassalador efeito, feito oxigênio discursivo quase invisível solto no ar do caminho da história do Brasil, para trás e para frente, inebriante para as elites intelectuais e políticas, grande parte delas, ao menos.

\footnotetext{
${ }^{15}$ Para Fernando Pessoa, o Padre Antônio Vieira (1608-1697) é um dos "inventores" do português, para quem o poeta cunharia o epíteto de "O imperador da Língua Portuguesa". Cf. Prefácio de ALFREDO BOSI (2011).
} 
A centralidade única que ganhou esse discurso na cena brasileira do século XX e XXI, espécie de discurso campeão sobre o social nacional, implicaria em um quase afogamento dos direitos pelo peso da herança discursiva das elites geração após geração, com seu tom homogeneizador que pintava, discursivamente, um Brasil ideal, apimentado com muita violência, mas que servia como luva para escamotear tenebrosos privilégios sobre terras, educação, dinheiro e poder, onde a "vergonha" que aparece empiricamente no discurso do Outro, apontada, por exemplo, na obra seminal "Brancos e negros em São Paulo", que expõe a ferida social e racial brasileira (FERNANDES; BASTIDE, 1959).

Essa intimidação, o preconceito e a inferiorização racial, operam contra o surgimento do discurso dos outros, dos direitos desses outros sociais presentes na história do Brasil, como os africanos e africanas escravizados, seus descendentes, os povos indígenas, também escravizados, seus descendentes, além de outros pobres seus descendentes.

As marcas de exclusão de herança dos Outros não passavam de pecados de nascença, para o discurso de Uns. Essas marcas, no entanto, eram inequívocas, pois,

a condição econômica, social e cultural dos negros é o aspecto mais terrível
de todo o quadro fornecido pelos dados do recenseamento. No censo de 1950 ,
os negros compreendiam quase 14 milhões (11\% da população total), mas
participavam de menos de 20 mil oportunidades como empregadores $(0,9 \%)$,
predominantemente em níveis modestos, e apenas $6.794(0,6 \%)$ e $448(0,2 \%)$
tinham completado, respectivamente, cursos em escolas secundárias e
universidades. Uma situação como esta envolve mais do que desigualdade
social e pobreza insidiosa. Pressupõe que os indivíduos afetados não estão
incluídos, como grupo racial, na ordem social existente, como se não fossem
seres humanos nem cidadãos normais (FERNANDES, 2007, 94).

"Contra dados e fatos" há argumentos, insurgem-se discursos acabados, consumidos, agradáveis, lapidadores da ordem social, sacralizados em rituais de poder: acadêmico, político, nacional, internacional, não importam se ficam fora do contexto quando a realidade teima em destroná-los.

Eles são como armas letais, espécie de "pau para toda obra discursiva" na defesa do status quo.

É o caso crasso do discurso do unionismo freyreano, adotado por Uns, majoritário dentre os donos do poder no Brasil, semeado à mão grande no meio do povo, ontem nos anos 1930 e não raro hoje.

É o chamado discurso da democracia racial (COSTA, 1998). Discurso feito mito no Brasil: "o mito da democracia racial". 
Ele é suficiente enquanto referência discursiva, pois indica um vetor para a análise fornecido pela história do Brasil, como expõe a autora:

em esboço, os fatos são suficientemente claros: um poderoso mito, a ideia da democracia racial - que regulou as percepções e até certo ponto as próprias vidas dos brasileiros da geração de Freyre - tornou-se para a nova geração de cientistas sociais um arruinado e desacreditado mito. Várias questões óbvias são sugeridas por esses fatos. Como puderam os brasileiros da geração de Freyre desconhecer seus próprios preconceitos? Como puderam os negros brasileiros daquele período permanecer cegos à discriminação que era uma experiência comum no seu cotidiano? Como puderam os brasileiros cultos, fossem eles brancos ou negros, ignorar a discriminação racial quando esta estava claramente demonstrada pelas estatísticas oficiais amplamente divulgadas? Qualquer um que soubesse ler e realizar simples operações aritméticas poderia ter observado os dados do censo oficial de 1950, que revelavam de maneira irretorquível a precária situação dos negros no Brasil. Estas estatísticas, por exemplo, classificavam cerca de $60 \%$ da população total como tecnicamente branca, cerca de $25 \%$ como mulata e $11 \%$ como negra. Mas as estatísticas referentes ao atendimento escolar de nível primário revelavam uma distribuição dramaticamente diversa. Apenas 10\% dos alunos eram mulatos e somente $4 \%$ negros. E nos estabelecimentos de nível secundário e superior o número de mulatos e negros era ainda menor. Somente $4 \%$ dos estudantes das escolas secundárias eram mulatos e menos de $1 \%$ eram negros. Nas universidades, apenas $2 \%$ eram mulatos, e somente um quarto de $1 \%$ era negro. (COSTA, 1998, p. 370/371).

Dois fatos históricos retumbantes na cena brasileira reforçaram o mito da democracia racial e escantearam a resistência a esse discurso. Em particular, aquela resistência feita pela educação popular, como a ação educativa de Paulo Freire no Nordeste nos anos 1940/50/60 e de Abdias do Nascimento, por meio do Teatro Experimental do Negro, no Sudeste, com destaque ao Rio de Janeiro, também nos anos 1940/50/60. A luta dos excedentes nos primórdios dos anos 1960 também acabaria nos camburões da história.

Os fatos são: o Golpe Militar de 1964 no Brasil que exilou Freire, Abdias do Nascimento, dentre outros - que sumiu com o quesito cor/raça do censo de 1970 - e o vendaval neoliberal de fora para dentro do país nos anos 1990 e seguintes, que colocou uma camisa de força nas políticas sociais aprovadas na Constituição de 1988, a pretexto do rigor fiscal do Estado Mínimo.

A precariedade relativa das estatísticas educacionais de negros e negras no Brasil não eram suficientes para sensibilizar os poderes de plantão no Brasil, tampouco a letra das leis inscritas na Constituição de 1988. O discurso da democracia racial que emergira quando o liberalismo era enterrado nos anos 1930 no mundo capitalista com as políticas keynesianas, parecia ressuscitar mais forte ainda com a ressureição do liberalismo nos anos 1990 como neoliberalismo triunfante, no curso da débâcle da URSS. 
A resistência discursiva, muito na invisibilidade, se fazia nos porões da sociedade brasileira. Mas, em 2001, na África do Sul, na Conferência de Durban contra o racismo, a xenofobia e as intolerâncias correlatas, as estatísticas da pretensa democracia racial brasileira, deram no inverso: denunciaram para o mundo todo a reprodução relativa da precariedade da condição social e educacional do negro, da negra no Brasil.

Os estudos de Hasenbalg (1997), Henriques (2001), Theodoro (2008) e Paixão et al (2010), repisaram as teses dos estudiosos dos anos 1950/1960, com refinamento estatístico, onde o discurso da situação social real de negros, negras, indígenas em variados quesitos, como o direito à educação em todos os níveis, descolava o discurso ideal da democracia racial do Brasil real.

Ao pôr os pés na periferia brasileira no século XXI caminha-se na direção dos outros sociais, seus discursos. Ao fazer isso, olha-se para trás simultaneamente, porque os discursos não brotam do nada.

Ao comparar a evolução da conquista da cidadania no Brasil, do ponto de vista do direito do negro, vis-à-vis a leitura clássica de Marshall ${ }^{16}$ sobre a conquista dos direitos civis, políticos e sociais na Inglaterra, emerge um artigo ímpar de Guimarães (2012), que aborda os discursos sobre as relações raciais na história do Brasil e é tomado como referência nessa dissertação, sobre o que se alongará oportunamente.

Do corpus tomado como presente emerge - feito fonte documental relevante um fragmento de realidade da educação brasileira.

Nele como brenha, quebrada, favela, viela, baixio, morro, mangue, palafitas, sertão, roça, mato, baixas periferias, estão os discursos dos outros sociais, homens e mulheres que sonham em ir para a universidade no Brasil, os Sem Universidade.

\footnotetext{
${ }^{16}$ Cf. MARSHALL (1977).
} 
Ao falar em sujeito do discurso e em interdiscurso abre-se um caminho analítico. Se o corpus revela elementos discursivos suficientes para a percepção de que há novíssimos "jogadores no jogo" no campo educacional brasileiro, isso encoraja a meta analítica, dá-lhe razão objetiva.

Para tanto, a dissertação precisa demonstrar habilidade em relacionar discursos convocados a partir do corpus, que indicam referenciais discursivos anteriores aos discursos presentes no corpus, mas que dialoguem com eles. Tais referenciais discursivos devem remeter à constituição do Brasil enquanto nação independente. Nesse ínterim, o esforço da dissertação requer a seleção de discursos sobre a temática surgida do corpus e que estão presentes na história da realidade discursiva brasileira e inscritos institucionalmente.

Os discursos produzidos na história brasileira sobre as relações raciais e sociais, na perspectiva da presença ou não da democracia na sociedade brasileira desde que ela se fez nação, da presença ou não dos direitos civis, políticos e sociais para os que habitam o Brasil, da extensão ou não da cidadania plena para todos e todas no Brasil interessam como objetivo da dissertação, na esteira do interdiscurso. Logo, são alguns os discursos que interessam. Não a totalidade dos discursos que brotaram neste terreno.

Pois, desde este ponto se pode falar da exclusão da universidade no Brasil ou não, da cor/raça dessa exclusão, da renda, da origem em escola pública ou privada, dos territórios da exclusão.

Igualmente, esse esforço requer um recorte analítico e uma arbitragem à priori dos principais discursos, com base em balizada argumentação. São os discursos constituintes. Essa escolha, feita com base em Guimarães (2012), Carneiro da Cunha (2012), Hofbauer (2006), dentre outros autores, indicam cinco discursos que ora já são tomados como os discursos constituintes nessa investigação (serão detalhados oportunamente).

São eles: E1, o discurso do embranquecimento; ML2, o discurso do mulatismo; I3, o discurso do indianismo; N4, o discurso da negritude e PI5, o discurso dos povos indígenas.

Isso posto avança-se para um afunilamento, um objetivo central da dissertação.

O corpus como ele é pode ser dividido em três partes: 
1) Os textos produzidos, que estão inscritos no gênero do discurso chamado argumentação, que são os registros documentais do fazer discursivo;

2) As mediações ou referências diretas, que são uma coletânea de excertos de textos, com distintas visões sobre alternativas de políticas para o acesso à universidade no Brasil, base direta para a produção textual;

3) Indicativos qualitativos e quantitativos, diretos e indiretos, de disposições culturais e do capital cultural dos agentes.

Com base na análise dos discursos presentes no corpus, o objetivo é a percepção da emergência do discurso de "novíssimos" sujeitos sociais no cenário da educação popular brasileira, da emergência do discurso dos Sem Universidade.

\title{
1.6. Hipótese
}

Importa expor, desde logo, a pergunta da investigação de modo simples. Em que medida, o corpus, considerado como documento nessa investigação, oferece indícios da presença do discurso dos Sem Universidade no processo de luta pelo direito à universidade no Brasil no começo dos anos 2000?

Essa pergunta, presente na $\mathrm{AD}$, implica numa reflexão, o que emite sinais do rumo teórico dessa investigação, lastreada na categoria de interdiscurso.

Maingueneau (2008, p. 39) afirma que,

\begin{abstract}
por enquanto, admitimos como uma evidência que existia uma dissimetria radical entre os protagonistas do espaço discursivo. Na medida em que, cronologicamente, é o discurso precisamente chamado "segundo" que se constitui através do discurso "primeiro", parece lógico pensar que esse discurso primeiro é o Outro do discurso segundo, mas que o inverso não é possível. Na realidade, as coisas são bem menos simples.

A partir do momento em que essa transformação é um processo que diz respeito ao conjunto de condições de possibilidade semânticas do discurso primeiro e cujo produto é um discurso concorrente, concebe-se facilmente que o discurso segundo seja imediatamente apreendido pelo discurso primeiro como uma figura privilegiada de seu Outro. Como ele jamais é constituído ex nihilo, mas no interior de um espaço discursivo anterior, é compreensível que o discurso segundo remeta no todo ou em parte ao Outro através do qual ele mesmo se constituiu.
\end{abstract}

É preciso de pronto sair à caça dos discursos constituintes. Mas, o que são eles? Como defini-los, que ingredientes mínimos são suficientes para a garantia de uma dimensão de discurso constituinte para um dado discurso? 
Maingueneau (2006, p. 37-38) sustenta que os discursos constituintes "operam uma função que poderíamos chamar de archeion";

esse termo grego, étimo do latino archivum, apresenta uma polissemia interessante para nossa perspectiva: ligado a arché, "fonte", "princípio", e a partir daí "comando", "poder", o archeion é a sede da autoridade, um palácio, por exemplo, um corpo de magistrados, mas também os arquivos públicos. O archeion associa assim intimamente o trabalho de fundação no e pelo discurso, a determinação de um lugar associado a um corpo de enunciadores consagrados e uma gestão da memória.

Um discurso constituinte extrairia autoridade de si mesmo e de mais ninguém, o que varia em função do discurso considerado, pois,

na verdade, a enunciação se manifesta como dispositivo de legitimação do espaço de sua própria enunciação, a articulação de um texto e uma maneira de se inscrever no universo social. Recusamo-nos, assim, a dissociar, na constituição discursiva, as operações enunciativas pelas quais se institui o discurso, que constrói, assim, a legitimidade de seu posicionamento, e o modo de organização institucional que o discurso ao mesmo tempo pressupõe e estrutura (MAINGUENEAU, 2006, p. 41).

Essa "noção de discurso constituinte (uma categoria insólita) se assenta sobre propriedades ao mesmo tempo enunciativas, funcionais e situacionais" (MAINGUENEAU, 2006, p. 43).

Os discursos constituintes implicam "um sistema de referencias aos outros discursos através do qual ele se constitui e se mantém" (MAINGUENEAU, 2006, p. 43). Eles são geridos por comunidades específicas e "falar de 'comunidade discursiva' é afirmar que, por um movimento de envolvimento recíproco, a comunidade é cimentada por discursos que são produtos dessa mesma comunidade" (MAINGUENEAU, 2006, 46).

Nas malhas do "insólito" está a "difícil negociação entre o lugar e o não lugar", marca registrada do discurso constituinte, a paratopia,

sem "localização", não há instituições que permitam legitimar e gerir a produção e o consumo das obras; mas sem "des-localização" não há verdadeira obra, porque é uma força que excede toda a sociedade que confere sua legitimidade aos que falam desde os discursos constituintes (MAINGUENEAU, 2006, p. 46).

Não nos alongaremos neste ponto. Importa deter que,

o caráter constituinte de um discurso confere uma autoridade particular a seus enunciados, que são investidos de toda a autoridade conferida por seu estatuto enunciativo. Mais do que de "enunciado", de texto, ou de "obra", a questão aqui é de inscrições. O conceito de inscrição contraria qualquer distinção empírica entre o oral e o gráfico: inscrever não é necessariamente escreve. (MAINGUENEAU, 2006, p. 47). 
Essa noção confere mais uma dimensão aos discursos constituintes, pois seus enunciados caracterizam-se por "estarem mais ou menos fechados em sua organização interna e serem reinscritíveis em outros discursos" (MAINGUENEAU, 2006, p. 47), além de articular "uma maneira de dizer e um modo de veiculação dos enunciados que implica um modo de relação entre os homens" (MAINGUENEAU, 2006, p. 48). Outra dimensão central é que,

o discurso constituinte implica assim um tipo de ligação específica entre operações linguageiras e espaço institucional. As formas enunciativas não são aí um simples vetor de ideias, elas representam a instituição no discurso, ao mesmo tempo em que moldam, legitimando-o (ou deslegitimando-o) esse universo social no qual elas vêm se inscrever (MAINGUENEAU, 2006, p. 54).

A busca pelos discursos constituintes nessa dissertação não desconsidera suas dimensões "insólitas". A grande fundação, a grande arqueologia tem um referencial: o Brasil. Pois é no passo de virar nação independente que comunidades discursivas fechadas, como aquela da elite de mando, vale-se do discurso constituinte da nova nação na sua "relação com os homens e mulheres".

Assim um grande dispositivo se apresenta de saída, no contrato de nascimento do Brasil: a Constituição outorgada de 1824 por D. Pedro I, que irá valer até 1891. Esse dispositivo inscreve um discurso constituinte, é o lugar institucional desse discurso. Seu correspondente não-lugar ou archeion remete a uma Europa comandada por homens brancos, a uma Portugal de reis, rainhas, princesas e príncipes brancos com casamentos inter-raciais arrumados, ao Congresso de Viena de 1815, que intenta restaurar as monarquias hereditárias na Europa. O Absoluto desse discurso constituinte, no limite, é o próprio absolutismo, pode ser ainda um grandioso império português ideal imemorial, o que remeteria a Dom Sebastião, o rei jovem do Portugal Grande que morreria nos idos de 1580 na batalha de Alcácer-Quibir na África. Por intermédio do exercício constitucional do poder do Padroado (comando sobre a Igreja) e do poder Moderador (exclusivo do Imperador), do falado e do calado que também fala, como o liberalismo de fachada com escravização e logo, inferiorização de africanos escravizado e indígenas também passíveis de escravização, institucionaliza-se uma hierarquia social e racial extremamente verticalizada, untada por asseclas e uma comunidade discursiva particular, que conforma uma elite branca de mando sobre os outros sociais.

Assim, a fundação do Brasil, vista pelo seu contrato de nascimento, também é a fundação do divórcio entre a Nação que a Constituição prescreve e o povo real, que o lugar abriga, as gentes que o território brasileiro tem. 
O que está em jogo? Que discursos entram no jogo?

Está em jogo o parto do Estado Brasileiro, sua gênese. Nesse processo histórico inscrevem-se os discursos constituintes desse estudo, alguns dos possíveis, não todos. É a cena histórica que leva da "Casa do Rei” (o Paço Real, na Praça XV, no Rio de Janeiro) para a "Razão de Estado", do mundo doméstico para o mundo público, depois o Catete, depois a Praça dos Três Poderes, em Brasília. É a forja que lavra o que é "universal" no Brasil depois da Independência de 1822 e a perenidade da disputa das forças sociais sobre o seu sentido ao longo do tempo.

O escravizado indígena, depois só indígena, está contemplado no universal nacional do Estado Brasileiro ou não? O escravizado africano, depois o negro, está contemplado no universal nacional no correr dos dias do novo Estado Nacional? Qual a posição dos brancos de herança europeia no universal do novo Estado-Nação? Estão dentro ou fora, são dominantes ou dominados?

O Estado Nacional novo nas Américas, em sua gênese, concentrou o monopólio da violência física? O monopólio da arrecadação dos impostos? Instituiu o campo burocrático do poder de Estado como monopólio legítimo, legal, racional nas margens dos tipos weberianos? O que era traço marcante do doméstico, da casa do rei, como a herança de sangue para o pleno exercício do domínio do poder de Estado cedeu espaço para uma nova burocracia de Estado calçada no capital cultural advindo dos títulos acadêmicos - os bacharéis que durarão ao menos até 1930 - e não mais dos títulos de nobreza, como duques, condes, viscondes e que tais? Houve na gestação do Estado Brasileiro a permuta das nobrezas de Estado: daquela da dinastia de sangue por outra de ilustração acadêmica, de capital cultural via diplomas?

Talvez em nenhum outro lugar do mundo o conceito teórico de Estado como o monopólio violento - frise-se, sem peias - do poder simbólico ${ }^{17}$ legítimo por parte dos dominantes sobre os dominados, ganhou guarida mais cruel como na gênese do Estado Brasileiro, e de igual modo, em suas estratégias de reprodução, que souberam perpetuar

\footnotetext{
17 “O poder simbólico como poder de constituir o dado pela enunciação, de fazer ver e fazer crer, de confirmar ou transformar a visão do mundo e, deste modo, a acção sobre o mundo, portanto o mundo; poder quase mágico que permite obter o equivalente daquilo que é obtido pela força (física ou econômica), graças ao efeito específico de mobilização, só se exerce se for reconhecido, quer dizer, ignorado como arbitrário. Isto significa que o poder simbólico não reside nos "sistemas simbólicos" em forma de uma "illocutionary force" mas que se define numa relação determinada - e por meio desta entre os que exercem o poder e os que lhe estão sujeitos, quer dizer, isto é, na própria estrutura do campo em que se produz e se reproduz a crença. O que faz o poder das palavras e as palavras de ordem, poder de manter a ordem ou de a subverter, é a crença na legitimidade das palavras e daquele que as pronuncia, crença cuja produção não é da competência das palavras.” (BOURDIEU, 1998, p. 14-15).
} 
no tempo, um assaz controle do universal, do público, sem ser demasiado dizer, por muito tempo, em mãos de pequenas minorias sociais sobre vastos contingentes humanos em condição de "desapossamento" econômico, político, cultural, mas sobremaneira, da posse da concentração extremada do poder simbólico pelos dominantes.

Se "Max Weber diz que o Estado é o monopólio da violência legítima. E eu o corrijo dizendo: é o monopólio da violência física e simbólica” (BOURDIEU, 2012, p. 450), com o Estado aparece também a noção de "cidadão" em oposição a "súdito". Aprofundemos um pouco:

\begin{abstract}
o modelo francês é o modelo das Luzes: cosmopolitismo, racionalismo, universalismo, universalismo abstrato, formal. Aí, Marx tem razão, é a filosofia da assimilação, concebida como universalização, como identificação de todo homem - identificação a priori e, se possível, a posteriori - com esse cidadão universal que é o cidadão francês. A via alemã é, de seu lado, ligada ao século XIX, ao romantismo; seria preciso evocar tudo, o tema da nação, do obscuro, do profundo, da Kultur contra a Zivilisation etc. A nação, nessa perspectiva, é uma individualidade enraizada historicamente, organicamente desenvolvida e unida por um volkgeist, por um espírito do povo comum que o distingue das outras nações e que se exprime numa linguagem, num costume, numa cultura e no Estado (BOURDIEU, 2012, p. 457).
\end{abstract}

Para gerir o estatuto do que é universal ou não, de quem é cidadão ou não dentro do território, do passo nada óbvio do Estado para o Estado-Nação, ainda que o Brasil tivesse no começo do caminho a pedra fundamental de uma dinastia, o parlamento, em tese, definiria as regras desse jogo entre os agentes sociais em disputa pelos sentidos do poder simbólico no âmbito do território brasileiro e o instrumento para tanto é a Constituição, base em que se assenta o consenso nacional em torno do poder simbólico que dá os contornos do Estado e o dissenso discursivo regulado que lhe é complementar, seja no mundo do papel ou como a encarnação viva da violência simbólica legítima de Estado presente no mundo real.

No processo de formação do Estado brasileiro, a disputa pelo "monopólio da violência simbólica legítima" (Bourdieu, 2012), pela concentração da arrecadação dos impostos, do poder político e da violência física, a demarcação dos limites do território, a língua, os símbolos pátrios, pelo que cabe e pelo que fica de fora do universal instituído pelo novo Estado-Nacional, muitas palavras, ainda que algumas delas na letra da lei, ganharam morada em terreno abstrato.

O universal abstrato mais abrangente é "povo", verticalizado. Palavra que ecoará nos tempos e estampará manuais didáticos. 
Esse "povo" uno e indiviso é o universal cozido pelos discursos oficiais e que geralmente não anda só na história do Brasil, lhe dando guarida outros tipos abstratos, feito um séquito, como o "índio", “o sertanejo”, o "gaúcho", "o escravizado negro".

Os indivíduos abstratizados ensejam um jogo abstrato, imaginário, que juntados inauguram uma imagem discursiva da unidade, condição sine-qua-non do parto do Estado brasileiro: nesse imaginário que empolga o discurso oficial estão lá o povo abstrato ( o popular e o não-popular), a nação abstrata, a pátria abstrata e o próprio Estado como uma nuvem abstrata, que desde a capital, o Rio de Janeiro, paira muitas vezes sobre um nacional abstrato.

Entrementes, não há espaço para a ilusão: o monopólio da violência simbólica legítima é real e o novo Estado é um fato histórico.

No parto do Estado brasileiro, visto por meio das constituições, cabem perguntas simples: onde ficam os registros das contradições possíveis entre o real e esse abstrato discursivo, por exemplo, entre a diversidade real do povo e o povo abstrato dos discursos do parlamento?

Não há escapatória: no nascimento do Brasil como Estado-Nação, "povo, nação, cidadão e Estado são, simultaneamente, reais e imaginários".

A harmonização é violenta, a unidade nacional acontece pari-passu sob "o regulamento das leis", o exercício extremado do monopólio da violência simbólica legítima pelo Estado, como está em sua escrita e como transborda na prática social com o passar dos tempos. A violência que ladrilha a nação meio que se perpetuará nos tempos, no geral, muito além da "letra da lei" ou mesmo "do espírito da lei", mas como uma espécie de estrutura estruturante da realidade nacional que mata muito ou manda matar muito para a garantia da perpetuação do padrão de desigualdades. Violência direcionada muito mais a uns corpos que outros.

Os discursos constituintes sobre o Brasil ocupam assim a cena histórica e, dos muitos possíveis nos ocuparemos apenas de alguns para quem sabe aprender como ensina Valter Benjamin, "a escovar a história a contrapelo".

O Estado-Nacional brasileiro, em seu curso, instalará, definirá o universal: a nação, o povo, quem é cidadão, quem não é.

Lá estarão os "calçados" e os "descalços", os “doutores" e os "analfabetizados”, os pretos, as pretas, os brancos, as brancas, os indígenas, as indígenas e as estigmatizações como auras a definir o racismo, o preconceito sobre os comuns dos mortais que habitam o território, a estigmatização do dominado pelo dominante: "o 
preto de alma branca", "a ralé", a "gentalha ignorante" e como parte do mesmo povo brasileiro, "a elite branca escravizadora de negros e indígenas", " a gente graúda das grandes quantidades de terras e dinheiro", os "letrados". O jogo discursivo é vivo.

É evidente o tensionamento, a disputa pelo monopólio do poder simbólico legítimo por muitas luas na história do Brasil. Se na origem e por muito tempo, nação e povo serão apenas símbolos eleitos como "arquétipos gerais" pelos discursos oficiais, numa espécie de fantasmagoria de tipos gerais independente da realidade social, o que tem muita serventia para apagar as diferenças, essas diversas diferenças regionais, raciais, presentes no real nacional, resistem e armam discursos de resistências, de baixo para cima, nos veios e interstícios do real no cotidiano nacional.

E é de pasmar: o bastão desse divórcio entre povo e nação abstratos e o povo real e a nação real passa de Constituição para Constituição, de 1891 para 1934, de 1934 para 1937, de 1937 para 1946, de 1946 para 1967/1969. O bastão discursivo dominante passa de fiador a fiador, ainda que haja as diferenças entre esses fiadores, os outros sociais no território sempre viram "subentendidos" sob um "manto geral" conveniente para as elites de mando, no geral, brancas. O que estava na gênese, reproduz-se em algum tom na herança.

Não só Coimbra, mas Montpellier, onde elites nacionais aprenderam o discurso do positivismo de Auguste Comte - um monarquista - contribuiria também para manter ou aumentar o peso discursivo do abstrato na construção do universal do Estado brasileiro no século XIX e depois.

Assim, a presença humana na bandeira nacional, um dos maiores referenciais simbólicos da República e da nação brasileira, se acha no meio da natureza dominante na bandeira, invisível atrás do dístico discursivo positivista "ordem e progresso" ao centro da bandeira, onde o discurso da ordem serve para "prever e prover" e o "progresso humano" é o rumo natural da cultura nacional em sua caça pela civilização, cujo ápice é a sociedade branca cristã europeia da segunda metade do século XIX.

Por seu turno, de per si, isso gestaria, em tese, a domesticação do povo perante os mores nacionais que comandariam o poder simbólico do Estado brasileiro com "uma imagem mítica de uma nação não violenta e de um povo ordeiro e pacífico", como ensina Marilena Chauí (CHAUÍ, 2000). E assim, o golpe militar que pariu a República, foi feito sem povo, apesar dele lá estar, muito bem invisível na bandeira do Brasil.

A afirmação de que até a Constituição do período militar (1964-1985), a gestão do universal no Brasil reproduziu o poder simbólico de 1824, depois o de 1891, é 
sustentada por Florestan Fernandes em reflexão aguda, que amarra a argumentação não idílica dos despossuídos do capital simbólico no Brasil na reprodução do Estado brasileiro:

\begin{abstract}
Esse pano de fundo pode passar por um "fenômeno natural". Ocorre, porém, que ele favorece a perpetuação e sob certos aspectos, a revitalização do padrão tradicionalista e assimétrico de relações raciais. Êsse padrão manteve-se por assim dizer intacto até , 1930, aproximadamente, ou seja, após a Abolição! E, ainda hoje, não se poderia dizer que tenha entrado em crise irreversível ou que esteja em vias de superação. Ele se preserva parcialmente, mas encontra reforços contínuos na extrema desigualdade da situação econômica e do destino social dos dois estoques "raciais" em presença. A alternativa do desaparecimento final desse padrão de relação racial só se concretizará historicamente a partir do momento em que a população negra e mestiça da cidade consiga, em bloco, situações de classe equivalente às que são desfrutadas pela população branca. $\mathrm{O}$ que significa $\mathrm{o}$ mesmo que admitir que isso sucederá quando a ordem social competitiva estiver despojada das inconsciências econômicas, sociais e culturais que se objetivam em torno das tendências de concentração racial da renda, do prestígio social e do poder. (FERNANDES, 1968, p. 124).
\end{abstract}

Diz o escravizado negro perante a Lei do fim do Tráfico de Escravos de 1831: "É para inglês ver". A tensão entre as comunidades fechadas em seus enunciados fundadores da nação arrastar-se-á nos tempos.

O lugar do outro social, étnico dentro do universal do Estado-Nação, ganhará a letra da lei maior apenas na Constituição de 1988, no seu preâmbulo, em particular, em itens específicos e nas suas margens, naquilo que ficaria para ser regulamentado depois, como a demarcação das terras indígenas e de quilombos. As constituições estaduais da Bahia e do Pará, no ciclo histórico da Constituição de 1988, escreveram em tintas o direito dos afrodescendentes de modo mais incisivo que a lei geral.

O artigo em uma revista científica, uma instituição, o IHGB, interpretará pioneiramente as relações raciais no Brasil nos anos 1840, pelas mãos do alemão Von Martius, numa espécie de lustro discursivo para a miragem constitucional de 1824 que pariu o Brasil. Esse artigo tem dimensão de "archeion", no sentido de inscrever e escrever em tintas, carregadas de mansidão, o sistema de relações raciais no Brasil.

À margem, atravessado pelo oral, uma África imemorial inscreve sua dor, sua cor, sua memória, pelo bastão discursivo passado pelos escravizados negros em mais de trezentos e cinquenta anos, onde um quilombo é uma instituição, como Palmares o foi nas terras brasileiras. A história mundial inscreve discursivamente a dispersão ${ }^{18}$

\footnotetext{
${ }^{18} \mathrm{Na}$ tradição do Antigo Testamento, parte primeira da bíblia cristã, aparece a diáspora longa, comum, de um só destino, dos judeus fugindo do Egito para a Terra Prometida. Esse registro também ocorre na Torá, livro sagrado dos hebreus. Comparado a essa narrativa, o que ocorreu num tempo muito mais longo, em cerca de quatrocentos anos, com crianças, mulheres e homens escravizados no continente africano, donde
} 
africana, a segregação dos homens, mulheres e crianças forçadamente e fragmentariamente retirados escravizados de variados lugares no continente para os tumbeiros que cruzavam o Atlântico para diferentes rumos. Os jogos linguageiros entre os homens do poder e os escravizados negros, africanos instauram um conflito discursivo. O Brasil também é lugar do negro e uma África imemorial é seu não-lugar, muito densa, humanamente densa, não cabe na moda.

"No tempo do Rei" e até os 1850, na capital do Brasil não era difícil de encontrar o Povo da Costa, do Congo, de Benguela, Moçambique, Loanda e Guiné, dentre outros, como os calejes. Pois,

um dos motivos para que tanta informação sobre as origens africanas tenha sobrevivido nos arquivos cariocas deve-se aos métodos de identificação utilizados pelos senhores. Em vez de anexar seu sobrenome de família ao prenome cristão do escravo, eles preferiam a fórmula de um nome cristão mais a "nação" africana (KARASCH, 2000, p. 42).

Assim apareciam no mercado de escravizados negros do Valongo, em casas de vendas de seres humanos "de primeira" ou de "segunda", "novos" ou "usados", nos nomes dos meninos e meninas nas listas dos cemitérios, nos jornais. Mas,

\begin{abstract}
as origens dos escravos do Rio eram tremendamente diversificadas. Da África, viajaram de pontos tão distantes quanto Cabo Verde e Quênia, incluindo as vastas regiões da África Ocidental, Centro-Oeste Africano e África Oriental. Das Américas, vieram de lugares tão distantes quanto os Estados Unidos e a Argentina. Do Brasil, suas terras natais iam das florestas tropicais do Amazonas e dos campos desertos do árido Nordeste ao interior do Mato Grosso e as vastas fazendas do Sul. Exceto por uma pequenina minoria nascida na corte, eles eram estrangeiros sem parentes numa terra alheia na qual teriam de lutar para sobreviver contra a probabilidade de uma morte precoce, adaptar-se a senhores estrangeiros e costumes estranhos, e tentar fugir de seu infortúnio. Porém não fazia tudo isso sozinho, pois construiriam novas lealdades a novas nações e formariam novas famílias e comunidades para ajudá-los a sobreviver, lidar com a situação e resistir; mas as memórias de suas terras natais e de suas famílias permaneceriam com eles nos anos difíceis que teriam pela frente, enquanto relembravam "minha terra e minha nação" (KARASCH, 2000, p. 66).
\end{abstract}

Com a vinda do Rei, a independência do Brasil, de 1808 a 1850, o Rio de Janeiro teve a maior população escravizada das Américas, contabilizando cerca de 80 mil em 1849, pelo censo feito.

saíram violentamente via Atlântico Sul, por exemplo, foi diferente. É o que argumentam criticamente autores estudiosos do pan-africanismo, como sustenta Éle Semog, biógrafo de Abdias Nascimento, visão que converge neste estudo. (SEMOG, 2006). A noção de "Êxodo", também da tradição judaico-cristã, apropriada para os estudos da revolução industrial e industrialização tardia, como na expressão "êxodo rural", também não nos parece apropriada aqui. 
A história dos povos africanas seria escrita em variados volumes pela Unesco na segunda metade do século XX. No século VIII, o Egito já tinha uma universidade de ponta, prova de que a história dos povos originários da África tem longa memória:

A memória dos afro-brasileiros, muito ao contrário do que afirmam aqueles historiadores convencionais de visão curta e superficial entendimento, não se inicia como o tráfico escravo e nem nos primórdios da escravidão dos africanos, no século XV. Em nosso país, a elite dominante sempre desenvolveu esforços para evitar ou impedir que o negro brasileiro, após a chamada abolição, pudesse assumir suas raízes étnicas, históricas e culturais, desta forma seccionando-o do seu tronco familiar africano. (Nascimento, 1980, p. 247).

Os povos originários, os povos indígenas, miram num lugar antes da presença do branco europeu invasor, e tem uma inscrição discursiva longa no tempo histórico, igualmente carregada de dor, eminentemente oral.

A resistência indígena contra a dominação branca é longa no tempo. A história registra essa tradição:

foi sem dúvida na Amazônia - entre todas as regiões brasileiras coloniais que as populações indígenas, de forma mais intensa e original, gestaram uma rica tradição de resistência a partir da formação de grupos de fugitivos. Mesmo considerando a imensidão dessa área, o pouco povoamento e a dispersão de vilas e povoados, os índios em tais mocambos não ficaram totalmente isolados. $\mathrm{O}$ incremento das fugas e de mocambos indígenas no Grão-Pará acontecia quando também ali desembarcavam africanos em maior quantidade. Seria possível sugerir que a tradição indígena de fugas logo se inspiraria naquela iniciada pelos africanos em algumas áreas. Os africanos e seus descendentes, com apoio e juntamente com os índios, criaram suas rotas de fuga, mocambos e buscavam a autonomia no meio da floresta (GOMES, 2005, p. 67).

Essas comunidades discursivas diversas (a elite branca dominante das constituições, os escravizados negros, os povos indígenas), ao menos três, indicam discursos fechados e "reinscritíveis" em outros discursos, com suas respectivas dinâmicas temporais. Se não conformam discursos constituintes ideais nos píncaros de uma modelização teórica ideal, perfeita, contudo, tem enorme robustez e aderência à teoria escolhida e, para o fito dessa dissertação, serão considerados como discursos constituintes, pois guardam dimensões relevantes de.

Assim, os discursos constituintes nessa dissertação tem um recorte na aparição do Brasil no concerto mundial das nações em 1822 e na longa história que segue de consolidação da cidadania na nação. Os discursos constituintes indicados, por seu turno, conformam o "espaço discursivo" dessa investigação, cujo detalhamento virá mais adiante.

Maingueneau (2010) enfatiza o "primado do interdiscurso" para o desenho do espaço discursivo, o que foi considerado. Isso organiza a construção da hipótese de 
pesquisa, pois os discursos E1, ML2, I3, N4 e PI5 - que serão desenvolvidos de modo mais detido adiante - remetem ao ponto de largada em que os discursos dos outros sociais, raciais, no Brasil, são inscritos interdiscursivamente na história.

A relação interdiscursiva, por seu turno, será perscrutada no começo do século XXI no Brasil, consoante o corpus particular, que é elevado à categoria de documento, registro histórico de dimensão intersemiótica, cujos textos argumentativos que o compõe, são tomados como discursos no fito de apreensão da presença de duas categorias analíticas: a mediação epistêmica e a responsabilidade argumentativa (ADAM, 2011, p. 113; 115).

Em termos da responsabilidade argumentativa, "o locutor é convidado a realizar por si mesmo o trabalho interpretativo" (ADAM, 2011, p. 113) no texto por ele produzido autonomamente, trata-se da responsabilidade pelo que diz, por seu ponto de vista, que estão escritos no documento, no corpus.

Onde, em quais endereços exatamente residem essas tintas da lavra do locutor no corpus, alçado à condição de documento, por sua dimensão histórica? No gênero do discurso avaliação de conhecimento que ele(a) escreve e em duas das questões selecionadas que ele(a) responde, pois o corpus (documento) é composto de três partes: um questionário socioeconômico, uma proposta de avaliação de conhecimento e um conjunto de doze questões também dissertativas.

Qual é o objetivo desse suporte? Trata-se de uma avaliação diagnóstica de conhecimentos para efeitos pedagógicos, de orientação do trabalho educativo, aplicada no momento inicial do processo de educação popular nas quatro experiências de cursinho popular do MSU destacadas. Essa avaliação de conhecimentos aconteceu no mesmo momento, realizadas num único lugar, não possuindo caráter eliminatório.

Complementarmente, cumpre dizer que nesse fazer discursivo do locutor, a mediação epistêmica indica qual a relação do locutor, na superfície textual, com os pontos de vista que lhe são apresentados como referência para sua escrita. No caso da avaliação de conhecimento, o locutor escreve em função de discursos materializados em uma coletânea de textos que obrigatoriamente devem ser considerados nas produções textuais. No caso das duas questões, cada uma delas, em si, materializa discursos particulares para a reflexão e o fazer discursivo do locutor. Esses atos de produção discursiva podem revelar ou não os discursos dos sujeitos.

Deriva desse conjunto de prerrogativas orientadoras da investigação a hipótese, formulada de modo conciso, em três passos: 
1) Dada a existência de discursos sobre as relações raciais e sociais no Brasil, que serão considerados discursos "constituintes";

2) Supõe-se a aparição de traços destes discursos "constituintes" no corpus da investigação;

3) Esses indícios, rumores, indicariam a presença de elementos discursivos que se reordenariam, feito discurso de um sujeito coletivo de direito, de modo a constituir um novo discurso, o que seria suficiente para se falar na emergência do discurso dos Sem Universidade no Brasil.

\section{NOS MAPAS DA FUNDAMENTAÇÃO TEÓRICA}

Para fins de garantir substancial aderência teórica ao objeto de pesquisa, há que se adentrar nos mapas da análise do discurso, suas fronteiras e tensões.

Há uma situação delicada, mas que precisa de um passo crítico. Maingueneau (2012) indica reflexões peculiares e preliminares para um enfeixamento teórico bem embasado desta investigação. Num mergulho na Antiguidade grega percebe que

[...] a reflexão sobre o gênero tem tido caráter heterogêneo, alimentando-se de duas tradições que, além disso, reivindicam a mesma filiação aristotélica: a da poética e a da retórica, tendo esta última proposto a célebre tripartição entre os gêneros "judiciário", "deliberativo" e "epidítico". Com o declínio da retórica, são sobretudo, os gêneros e subgêneros da literatura que passam ao primeiro plano. A extensão recente da noção de gênero ao conjunto das atividades verbais não é sem consequências; com efeito, de um lado, a análise do discurso usa uma categoria que, no decorrer de uma história bastante longa, foi ficando saturada de sentidos; do outro, a literatura vê-se hoje analisada através de uma categoria elaborada pela análise do discurso, categoria cujo nome lhe é familiar, mas que não é verdadeiramente a sua (MAINGUENEAU, 2012, p. 238).

Isso expõe parte das complexas relações entre a literatura e a análise do discurso. Não custa atentar-se para o fato de que a elaboração teórica de Bakhtin corrobora a visão acima, na medida em que, é ao menos de duas de suas obras capitais, como aquela em que ele debruça-se sobre a poética de Dostoievski e a outra em que elege a literatura de Rabelais, que emergem com força máxima algumas categorias centrais para a análise do discurso, quais sejam o dialogismo, a polifonia, o plurilinguismo, para ficarmos em três registros teóricos elementares da fornalha bakhtiniana. 
Logo, uma construção teórica interdisciplinar, que daria espaço para a literatura e para a análise do discurso, em tese, poderia ampliar a qualidade da abordagem, mesmo sendo muito delicado esse movimento, bem como os requisitos e os filtros necessários para a tessitura de uma sinergia teórica positiva entre as disciplinas.

Contudo, reconhecer limitações de uma intransigência puramente disciplinar, parece também útil para revelar radicalismos nem sempre perceptíveis quando se estica a corda entre análise do discurso e literatura, o que pode se revelar infrutífero teoricamente, pois,

\begin{abstract}
os analistas do discurso interessam-se mais pelos gêneros que designamos acima como "rotineiros", deixando os gêneros "autorais" aos especialistas em literatura, filosofia, religião etc. Assim agindo, retornam à divisão imposta pela estética romântica entre textos "intransitivos" - expressão da "visão de mundo" de uma individualidade criadora, e textos "transitivos", de prestígio bem menor, que estaria a serviço das necessidades da vida social. Não há, contudo, nenhuma razão teórica de peso para que a análise do discurso não aprenda uma parcela da produção verbal e para que os especialistas em literatura não remetam a generacidade dos textos que estudam à generacidade do conjunto das produções verbais (MAINGUENEAU, 2012, p. 239-240).
\end{abstract}

Outros três argumentos atinentes ao caso brasileiro nos parecem necessários e fundamentais para assentar uma confluência teórica entre essas disciplinas para os propósitos desta investigação. O primeiro diz respeito ao fato de que os dados que envolvem literatura emergem do corpus, portanto não se pode calar sobre isso na investigação; segundo, há a presença teórica na análise do discurso da noção de discurso literário como discurso constituinte ${ }^{19}$, o que é importante para a investigação e sua temática e; terceiro, o estudo de 2012 "Os modos de didatização em manuais de língua portuguesa para o ensino fundamental no período de 1976 a 1996”, de Santana (2012), aponta que a literatura é a referência central, tomada como espelho para a produção textual nas escolas brasileiras, pois tem presença visceral naqueles manuais. O período estudado por ela é coetâneo da assunção do MSU, cujos sujeitos são egressos da escola pública, como no caso da amostra documental dessa investigação.

Então, o percurso teórico que se avizinha tem característica interdisciplinar, com algum grau de amarração com o chamado paradigma indiciário ${ }^{20}$. Buscam-se bases teóricas sólidas para a melhor compreensão da ideia da emergência do discurso dos Sem Universidade presentes no corpus dessa pesquisa.

\footnotetext{
${ }^{19}$ Maingueneau (2012, p. 59; 71) faz essa sustentação, o que será oportunamente mobilizada no curso da dissertação.

${ }^{20}$ Cf. Ginzburg (1986). Mitos, emblemas e sinais.
} 
A amarração teórica em curso tem por base a linguagem e a educação, a análise do discurso e um pequeniníssimo diálogo com a literatura, enquanto discurso constituinte para a questão das relações raciais no Brasil, como vistas em dois autores nacionais de literatura brasileira: Machado de Assis e José de Alencar - pois, o Brasil por ser um país de universidades tardias, só terá produções acadêmicas de relevo sobre o assunto também tardiamente. Cruz e Souza, Lima Barreto, Aluísio Azevedo, dentre outros, repertoriam o cotidiano brasileiro ainda na virada do século XIX para o século $\mathrm{XX}$, onde os discursos constituintes sobre as relações raciais circulam no dia-a-dia.

Além disso, percebe-se que a literatura em parte abastece a investigação de profundidade analítica, pois alguns dos próprios constructos teóricos utilizados reflexivamente, como aqueles de Bakhtin, bebem nas fontes literárias de Rabelais e de Dostoievski.

Para uma fundamentação teórica pertinente ao objeto de pesquisa foram selecionados os seguintes autores, de moto complementar: Pêcheux (1982), AuthierRevuz (1982), Maingueneau (2006; 2008; 2010; 2012), Bourdieu (1983; 2001; 2005), Adam (2008), Ginzburg (1976) e Geraldi (1991).

Esta pesquisa tem ênfase em linguagem e educação, com centralidade para a análise de discurso, onde tem lugar analítico de relevo a categoria de interdiscurso, bebida do ensaio de Dominique Maingueneau, "Gênese dos discursos", a produção intelectual de Maingueneau, seu surgimento histórico na França e suas bases gerais analíticas.

\begin{abstract}
O recurso a uma semântica global da prática discursiva parece permitir-nos escapar a essa distribuição prejudicial de papéis. Comparada aos comentários tradicionais fundados sobre a "filtragem" dos elementos pertinentes, ou mesmo à explicitação de "semelhanças" formais, não há dúvidas que essa passagem por um sistema de restrições, por uma formação discursiva, parecerá um desvio custoso. Mas é o preço a pagar para poder pensar de maneira menos trivial a relação dos discursos abstratos com suas condições de produção. Com efeito, já que o que resulta do sistema de restrições é o conjunto do discurso considerado na irredutível diversidade de seus planos, basta que seja possível definir uma relação interessante entre este último e sua conjuntura histórica para que o conjunto da superfície discursiva correspondente seja parte relevante dessa relação. Evita-se assim distinguir dois tipos de constituintes nos textos: os que seriam ligados a um contexto sócio-histórico definido e os que, de certa forma, o transcenderiam. Em lugar de refletir sobre as unidades superficiais de interpretação evidente ou obscura, opera-se diretamente no nível das articulações fundamentais que as tornam possíveis. (MAINGUENEAU, 1995, p. 162-163).
\end{abstract}

A investigação avança, por partes:

1) A descrição do corpus documental intersemiótico; 
2) A caracterização dos discursos constituintes sobre relações raciais e sociais no Brasil;

3) A análise do corpus, considerando-se seus elementos inscritos relevantes: cerca de 350 redações-enunciados e 350 questionários descritivos;

4) Desenvolvimento de uma discussão e conclusão, confirmação ou informação das hipóteses de trabalho.

\subsection{O norte do discurso}

Ao entendimento teórico do que é discurso, pois. Começa-se por um texto clássico de Pêcheux, para que essa investigação avance nesse rumo.

“Ora, entre esses gritos de vitória, há um que vai 'pegar' com uma intensidade particular: é o enunciado 'On a gagné' ['Ganhamos'] repetido sem fim como um eco inesgotável, apegado ao acontecimento." (PÊCHEUX, 1997, p. 21). Mitterrand, no começo dos anos 1980, finalmente é eleito o Presidente da França.

$\mathrm{Na}$ cidade grande no Brasil, outra cena, anos mais tarde, nos mesmos 1980 . Na fábrica, pra espantar o sono, quatro da manhã de domingo, hora extra, sem chefe graúdo por perto, vez em quando também principiava uma gritaria de trabalhadores, de peões, sufoco tirado da garganta, aquilo batia nas máquinas e zunia, corria o imenso galpão. Seria o discurso do inconformismo dos peões de macacão azul e sapato preto pesado na grande multinacional da fotografia?

Tanto na França da vitória de Mitterrand, como no Brasil da ditadura militar onde os gritos de tortura não tinham muito tempo de idade - discursos repercutem, produzem ecos, por mais que particularidades históricas delimitem esses discursos: sejam eleitores comemorando vitória, crianças descalças na roça querendo ouvir o eco de suas vozes do outro lado do rio, trabalhadores espantando aos berros os demônios da madrugada de domingo no batente alucinante da linha de produção de uma fábrica fordista, gritos de tortura e gritos presos na garganta na luta contra a ditadura no Brasil,

mas, simultaneamente, o enunciado "On a gagné" ["Ganhamos"] é profundamente opaco: sua materialidade léxico-sintática (um pronome "indefinido" em posição de sujeito, a marca temporal-aspectual de realizado, o lexema verbal "gagner" ["ganhar"], à ausência de complementos) imerge esse enunciado em uma rede de relações associativas implícitas -paráfrases, 
implicações, comentários, alusões, etc - isto é, em uma série heterogênea de enunciados, funcionando sob diferentes registros discursivos, e com uma estabilidade lógica variável (PÊCHEUX, 1997, p. 23).

Como desbancar o acontecimento? O autor indica o caminha do implícito versus o explícito, nas pegadas da heterogeneidade presente de algum modo nos enunciados.

“On a gagnè!” [“Ganhamos!”]... nós nos havíamos regozijado do mesmo modo em cada vitória da esquerda, em maio de 36, na Liberação. Outros, antes de nós, tinham feito os mesmos discursos. "On a gagné!" ["Ganhamos"]. E a cada vez era uma "experiência" que não tinha durado muito, no atoleiro das abnegações, dos entusiasmos, brilho súbito e fogo de palha, antes da recaída, do desmoronamento e da derrota consentida. "On a gagné!" [“Ganhamos!']. Ganhamos o quê, como e por quê? (PÊCHEUX, 1997, p. 24).

Entra na conversa a memória e sai o inédito, o nunca visto. Uma memória reivindicada desde um ponto de vista, desde uma sequência histórica do já acontecido, espécie de retrovisor passeando no tempo histórico em direção aos urros mais primitivos de vitórias equivalentes ou carregadas de verossimilhanças.

Paira no ar a questão do sujeito do discurso.

O apagamento do agente induz um complexo efeito de retorno, misturando diversas posições militantes com a posição de participação passiva do espectador eleitoral, torcedor hesitante e cético até o último minuto... em que o inimaginável acontece: o gol decisivo é marcado e o torcedor voa em apoio à vitória. O enunciado 'On a gagné' [Ganhamos] funde "aqueles que ainda acreditavam nisso" com "aqueles que já não acreditavam” (PÊCHEUX, 1997, p. 24-25).

O grito, por estar quase solto no ar, remete a muitas vozes, menos a um coro ordenado e mais a balburdia da festa. A polifonia tomada em uníssono é um movimento no tempo e no espaço, um movimento de vozes que retumbam, assemelha-se ao efeito de massa descrito por Elias Canetti, em Massa e Poder,

o mais importante acontecimento a desenrolar-se no interior da massa é a descarga. Anteriormente a ele, a massa ainda não existe de fato. É somente a descarga que efetivamente a constitui. Trata-se do momento em que todos os que a compõem desvencilham-se de suas diferenças e passam a sentirem-se iguais. (CANETTI, 1995 [1960], p. 16).

Assim, no momento da comemoração da vitória eleitoral de Mitterrand - outra Bastilha? - espalha-se uma espécie de efeito massa, cujo eco decorrente disto, às vezes em graus variados de tempos e tons, é mobilizado pelo momento e depois mente, em retumbantes plurilinguismos nos variados lugares sociais e culturais.

Passado o acontecimento, meio que reconfiguram-se os sujeitos coletivos, cada um volta para seu "mundinho", seu lugar social diferente, com os seus próprios passos e as pedras do caminho, com seu ouvido e sua fala particular. 
As vozes, por suposto, são carregadas pelos ouvidos dos sujeitos, adiante, hora mais calados, hora mais palradores. O sujeito da história que construiu com seu voto a vitória de Mitterrand, doravante irá calar-se, irá falar? Qual fala? De que lugar, de que posição social?

Uma idealização por demais da situação leva a uma idealização dos agentes, numa corrida pelo homogêneo e gesta um retumbante "apagamento do agente" na estrada da miragem dos tipos-ideais. Para tanto, bastaria imaginar que os sujeitos da vitória eleitoral são uniformes, identicamente militantes, identicamente envolvidos com a política, idealmente mobilizados por um mesmo projeto de poder, uma só teleologia, uma transcendentalidade uníssona. Não seria o caso na vitória de Mitterrand, nem o fora na afamada Revolução Francesa.

De algum modo, o debate também não é novo. Remete ao longo curso dos embates entre as chamadas ciências da natureza e as chamadas ciências humanas, particularmente quando esta última se envereda pelos caminhos daquela quase que desembestadamente.

Em busca, à moda de Galileu Galilei para o Universo, de traduzir as sociedades, numa linguagem matemática pura, repleta de regularidades e leis gerais férreas. Não que a matemática não seja interessante, desperte curiosidade boa e conte muito nos passos da humanidade.

\footnotetext{
Nesses espaços discursivos (que mais acima designamos como "logicamente estabilizados") supõe-se que todo sujeito falante sabe do que se fala, porque todo enunciado produzido nesses espaços reflete propriedades estruturais independentes de sua enunciação: essas propriedades se inscrevem, transparentemente, em uma descrição adequada do universo (tal que este universo e tomado discursivamente nesses espaços) (PÊCHEUX, 1997, p. $31)$.
}

$\mathrm{O}$ autor nega assim, a viabilidade teórica de abordagens que pleiteiam um espaço social homogêneo, com indivíduos categorizados coercitivamente em leis de aço do tipo universais e meio que fatais. Tal lógica, não se sustentaria perante o "sujeito pragmático" ou os "simples particulares". Não dá conta da heterogeneidade do real e da necessária interpretação crítica da história.

O jeito de formular de Pêcheux (1997), em sua reflexão critica sobre a homogeneização discursiva ensimesmada em leis pétreas pretensamente infalíveis sobre o social, coloca em causa a questão das opções de linguagens e seus abusos, mesmo que uma delas não tenha na matemática sua fonte explanatória sobre o mundo como é ou como deveria sê-lo. 
Pêcheux (1997) também toma por fio analítico a fusão de duas linguagens para explanar sobre a realidade social e aborda o chamado estruturalismo político francês sem peias,

é antes de tudo esta posição de desvio teórico, seus ares de discurso sem sujeito, simulando os processos matemáticos, que conferiu às abordagens estruturais esta aparência de nova 'ciência régia', negando como de hábito sua própria posição de interpretação (PÊCHEUX, 1997, p. 47).

O horizonte dos sentidos e uma escuta das "circulações do cotidiano" indicariam, para Pêcheux (1997), um itinerário de trabalho intelectual fértil em análise do discurso. Nessa perspectiva, seriam requisitos: "dar o primado aos gestos da descrição da materialidade discursiva", baseado no "real da língua"; "todo enunciado" oferece "lugar à interpretação": "é nesse espaço que pretende trabalhar a análise do discurso".

O autor supracitado, numa ânsia de superação de limites desgastados para a análise do discurso, destaca também a "existência do simbólico", como percebidos nos estudos de Roman Jakobson e de Lacan. Este último sustenta que o entrelaçamento entre o real, o imaginário e o simbólico descortinam "transformações do sentido" e podem revelar, inclusive, uma dimensão "oscilante e paradoxal" como base interpretativa de um corpus particular, de um real singular, por exemplo.

Desce ao chão as perguntas básicas a que o "ganhar", senha analítica do autor, remete em potência quando guiado por um "sujeito animado", um sujeito que conta na história, não passivo em algum grau, na chave passivo/ativo donde se constitui o sujeito histórico coletivo. Por exemplo, os trabalhadores, os burgueses, os socialistas, os comunistas, os liberais. A disjuntiva "apagamento do agente" versus "sujeito animado", o que quer dizer? No plural, sujeitos animados ou agentes apagados?

Ora, as crenças na esquerda e na direita, metáforas visuais e discursivas que ecoam nos tempos, oriundas dos posicionamentos políticos dos grupos nas assembleias francesas do tempo da revolução de 1789, resistirão ao acontecimento de 10 de maio de 1981 na França? Ou negarão o acontecimento? Pêcheux põe em debate o "estatuto das discursividades", a estabilidade das "proposições", dos "objetos discursivos", os “enunciados reais". Isso interessa sobremaneira para esta investigação.

Pois são antigas as proposições discursivas ou a genética dos discursos sobre o social, o racial no Brasil. É o que informa essa amostra da lavra de Antonio Candido:

"No Brasil, costumam dizer que para o escravo são necessários três P.P.P., a saber, Pau, Pão e Pano" - dizia Antonil no começo do século XVIII, retomando o que está no Eclesiastes, 33:25, como assinala André Mansuy na 
sua edição erudita ("Para o asno forragem, chicote e carga; para o servo pão, correção e trabalho"). No fim do século XIX era corrente no Rio de Janeiro, como dito humorístico, uma variante mais brutal ainda: "Para português, negro e burro, três pés: pão para comer, pano para vestir, pau para trabalhar" (CANDIDO, 1993, p. p. 127-128).

Do cotidiano emergia uma língua ideológica dos três pês, untada da violência do real, que "visa ocultamente a definir uma relação de trabalho na qual o homem pode ser confundido com o bicho e tratado de acordo com esta confusão" (CANDIDO, 1993, p. 129). Não se iluda ninguém: ao passo que o português parecia que "trabalhava como um burro", ele podia subir e galgar o comando da sociedade de resquícios coloniais evidentes; já o negro (escravizado e depois liberto) ficava confinado nas camadas inferiores. As exceções endeusavam a regra e embaralhavam ou marcavam as cartas discursivas presentes na sociedade. A mulher negra escravizada ou alforriada de mentirinha era também uma máquina de ganhar dinheiro para seu explorador.

Esse discurso "dos três pês", de cartas marcadas, o norte discursivo que ele indica e que fará seguidores por gerações no Brasil, precisa ser desmascarado. Nisso a realidade faz chover sobre a tinta, desmanchando-a. Os interesses de classe e outros sujeitos discursivos desmascaram-se, deslocando a pretensão homogênea e universal do discurso dos pês sobre o Brasil ${ }^{21}$ :

daí a grosseria agressiva da formulação, feita para não deixar dúvidas: eu,
brasileiro nato, livre, branco, não posso me confundir com o homem de
trabalho bruto, que é escravo e de outra cor; e odeio o português, que trabalha
como ele e acaba mais rico e mais importante do que eu, sendo além do mais
branco. Quanto mais ruidosamente eu proclamar os meus débeis privilégios,
mais possibilidades terei de ser considerado branco, gente bem, candidato
viável aos benefícios que a Sociedade e o Estado devem reservar aos seus
prediletos (CANDIDO, 1993, p. 133).

A heterogeneidade está no ar e no chão do Brasil.

\footnotetext{
${ }^{21}$ Cf. CANDIDO (1993, p. p. 137-138): “Talvez a força do livro venha em parte desta contaminação do plano real e do plano alegórico, fazendo pensar imediatamente numa relação causal de sabor naturalista, que na cabeça dos teóricos e publicistas era: Meio - Raça - Brasil; e que no projeto do ficcionista foi: Natureza tropical do Rio - Raças e tipos humanos misturados - Cortiço. Isto é: no intuito de Aluísio a natureza que cerca o cortiço de todos os lados, com o sol queimando no alto, condiciona um modo de relacionamento entre os diversos grupos raciais, que por sua vez fazem do cortiço o tipo de aglomerado humano que é. E esta série causal encarnaria o que se passava na escala nacional, segundo as concepções do tempo. Esboçando já aqui uma visão involuntariamente pejorativa do país, o romancista traduz a mistura de raças e a sua convivência como promiscuidade da habitação coletiva, que deste modo se torna mesmo um Brasil em miniatura, onde brancos, negros e mulatos eram igualmente dominados e explorados por esse bicho-papão, o português ganhador de dinheiro, que manobrava tanto os cordéis de ascensão social e econômica nas cidades”.
} 
A ideia de fio do discurso é presente e representada em muitos discursos acadêmicos. Possivelmente trata-se de uma metáfora: um fio. Porém, seu sentido não é simples assim como aparenta. O fio tecido pela aranha é frágil, ainda que vital, frente ao fio de seda tecido pelo bicho-da-seda. O fio da rede nordestina é tecido a muitas mãos e sua força está no entrelaçamento e não no fio isolado per si. Esse talvez seja o princípio da corda feita de fibra vegetal. Gandhi para demonstrar legitimidade e força cultural passou a tecer suas roupas nas rocas de fiar comuns na cultura da Índia como forma de enfrentar o poderio inglês. $\mathrm{O}$ fio das rocas populares indianas demonstrou ser de grande força discursiva.

O outro na história, no texto, nos discursos, dá a dimensão das heterogeneidades. Isso é uma indagação forte no corpus, porque estabelece as relações entre o explícito e o implícito presente ali. Esse tipo de questionamento afasta também a armadilha de uma restrição argumentativa teórica que toma os discursos presentes na materialidade do corpus como meras homogeneidades de um tipo-ideal, como o "vestibulando", por exemplo, comum no discurso da indústria do vestibular, o que sequestra o estatuto do sujeito de direito à universidade, bloqueando a história e escanteando as heterogeneidades.

Por isso as pesquisas fundantes de Authier-Revuz (1978) são um passo teórico fundamental, à medida que auxilia na compreensão daquilo que constitui os discursos.

Pêcheux (1997, p. 51) aponta a importância da "heterogeneidade constitutiva" para a boa pesquisa linguística. Do que se trata?

Para a autora,

no fio do discurso que, real e materialmente, um locutor único produz, certo número de formas, linguisticamente detectáveis no nível da frase ou do discurso, inscrevem, em sua linearidade, o outro. Sob duas diferentes modalidades (tradutor ou porta-voz), o locutor dá lugar explicitamente ao discurso de um outro em seu próprio discurso (AUTHIER-REVUZ, 1978, p. 12).

"A autonímia e o jogo das formas da conotação autonímica permanece no campo do marcado e do explícito", onde se divisa o "um" e o "outro" no discurso (AUTHIER-REVUZ, 1978, p. 12). 
Surge de modo lúcido, a ativação de um movimento interdisciplinar para a interpretação dos sentidos do discurso, que vai da linguística para "abordagens nãolinguísticas",

para a descrição linguística das formas de heterogeneidade mostrada, a consideração da heterogeneidade constitutiva é, a meu ver, uma ancoragem, necessária, no exterior do linguístico; e isso, não somente para as formas que parecem oscilar facilmente devido às modalidades incertas de seu resgate, mas, fundamentalmente, para as formas mais explícitas, mais intencionais, mais delimitadas da presença do outro no discurso (AUTHIER-REVUZ, 1978, p. 22).

O dialogismo do círculo de Bakhtin, 'inscritos no campo semiótico e literário’ e a psicanálise lacaniana, que "tem por objeto o inconsciente", são as duas ancoragens de Authier-Revuz (1978) para uma apreensão, entendimento e fundamentação da heterogeneidade constitutiva da fala e do discurso. Isso é prova de que a necessidade de ultrapassagem dos limites da análise do discurso referida na linha estruturalista althusseriana, era um desafio teórico que além de Pêcheux (1997), mobilizou também a autora, dentre outros(as).

Mas, qual Bakhtin ou o quê nesse autor, no círculo, Authier-Revuz (1978) puxa, mobiliza, para dar densidade a seu constructo teórico? Ela restringe-se ao discurso, ao sentido e aos gêneros literários ou do discurso, como nos dois clássicos de Mikhail Bakhtin: "A cultura popular na idade média e no renascimento: o contexto de François Rabelais" e "A poética de Dostoievski"?

Com o auxílio da compilação das ideias de Bakhtin feita por Todorov (1981), a autora vislumbra um paradigma que perpassa os conceitos na estrada cultural de Bakhtin, gerados de 1920 a 1975 em terras da ex-URSS, em situação extrema: plurilinguismo, fronteiras, polifonia, pontos de vista, pluriacentuação, bivocalidade, interação verbal. O monólogo perde para o diálogo; o múltiplo desloca o único; o outro aparece no um ao invés do um e o outro; fica para trás o homogêneo e se vislumbra as fronteiras no heterogêneo; aquilo que se apresenta imóvel, feito peça de museu, cede lugar ao conflitual: o que tinha centralidade absoluta torna-se relativo e a ideia do acabado, do absoluto, dá vez ao inacabado ${ }^{22}$,

o que se diz de maneira insistente através desta rede de oposições é o lugar dado ao outro na perspectiva dialógica, mas um outro que não é nem o duplo de um frente a frente, nem mesmo o "diferente", mas um outro que atravessa constitutivamente o um (TODOROV, 1981, 25).

\footnotetext{
${ }^{22}$ Em Paulo Freire, a ideia do homem como ser inacabado, em constante e interminável construção, faz parte da concepção de uma educação popular humanizadora do mundo.
} 
Mesmo falando em termos de paradigma para uma leitura de Bakhtin, a autora tende a simplificar e cravar um "monológico" nas ciências exatas, o que soa generalista demais, pois não é trivial assim e, ao mesmo tempo, nomeia uma "lei do discurso", o que é arriscado, por conta da experiência das leis assemelhadas, vistas no caso do estruturalismo político francês, presente na crítica de Pêcheux (1997).

Assim, nos apartamos de uma leitura que perscruta as dimensões variadas da heterogeneidade do discurso naquilo que aparenta demasiada procura por leis transcendentais e, no limite, distanciamo-nos também duma ênfase demasiada na “ideologia”, relativizando-a ${ }^{23}$. De qualquer modo, o que a autora busca frisar é que "[...] a relação com o outro é uma fronteira interior [e esse] princípio fundamental constitui tanto o discurso, a palavra, o enunciado, o sentido quanto às formas e gêneros literários" (AUTHIER-REVUZ, 1982, p. 27).

O meio histórico, a semiótica discursiva e o discurso literário se imbricam intimamente, desde esse ponto de vista, pois o dialogismo, além de outras categorias de Bakhtin, emerge apenas a partir da existência de uma profunda reflexão do autor baseado no discurso literário de Dostoievski e de Rabelais, pois no deserto é raro o que germina.

Ao falar do plurilinguismo a autora destaca a força dialógica do riso, tomada da cultura popular, das festas populares, como espécie de mola propulsora do Bom Pantagruel, o gigante, metáfora da densidade humana na Terra, de um sujeito humano que toma o centro da história, por que não do discurso, que na ocasião, era hegemonizado pelo teocentrismo cristão na latinidade e suas ramificações, em pé de guerra, pelo brotar dos galhos do tronco histórico do cristianismo, um sujeito do discurso que emerge dos escritos do francês François Rabelais, que é no fundo, o

\footnotetext{
${ }^{23}$ A ideologia ou a arte de transformar interesses privados, particulares, em interesses pretensamente gerais da sociedade, públicos, é um ingrediente servido ainda hoje nos lares mundo afora, às vezes em doses homeopáticas, outras em doses cavalares, como um complemento cotidiano mental para as refeições que abastecem o corpo físico dos indivíduos e até a fome, como percebera já em sua época o velho Marx, ao identificar que a burguesia europeia transformava seus interesses de classe em interesses do Estado. O limite disto em 2013, em tempos globalizados, é o caso de Snowden, funcionário de empresa americana que denunciou a existência de um programa de computador chamado PRISM, capaz de vasculhar qualquer informação pessoal de qualquer mortal que faça parte da rede mundial de computadores, a famigerada internet, tudo em nome da ideologia da segurança nacional norte-americana. Bentham, Orwell ou Foucault teriam em mãos elementos ricos para análise, quem sabe vertigens. Assim, descuidar do peso da ideologia no mundo real pode ser perigoso demais. No entanto, TEZZA (2002), não chega a tais limites. Ao relativizar uma leitura eminentemente ideológica de Bakhtin, o autor busca driblar os véus soviéticos e lançar mais luz sobre a polifonia, o plurilinguismo, o dialogismo, indo além de um registro demais formalista.
} 
relativo em Bakhtin, em oposição, ou muito além do dogmatismo linguístico daquela França quinhentista das fileiras cerradas da contrarreforma, ou além dele.

Aqui o Brasil surge como um paralelo bom, em função da temática desta investigação. Afinal, os jesuítas que para cá vieram em 1554 eram os soldados do exército de Cristo, um exército montado na reação da Igreja Católica ao avanço da Reforma Protestante. Foi com esse ethos discursivo, nessa cena histórica, que os jesuítas semearam seus colégios no Brasil "descoberto". Na prática, criaram o primeiro sistema de educação do Brasil (AZEVEDO, 1976).

O discurso monológico e verticalizado dominante então, em França de Rabelais, como no Brasil de Anchieta, num certo olhar, dava-se basicamente devido ao fato das religiões monoteístas e mesmos seus cismas e heresias, caso do imenso poder da Igreja católica, tomarem por condão um único livro, como a Bíblia. Por outro lado, para o bem ou para o mal, um exclusivismo monológico sobre o livro sagrado não deixa de ser uma visão limitadora, pois se "No princípio era o Verbo" (Gênesis), a voz, as palavras, a árvore, os vários "livros", "autores", "locutores" que compõem a bíblia cristã ecoam variados discursos, de poemas eróticos a conselhos, de táticas de guerras a gestos de paz. Portanto, discursos em nada monológicos, como se percebe, paradoxalmente.

Discursos e heterogeneidades que vão adiante empurrados pelos tempos, desde a potência restante do Império Romano cristianizado, até os vários galhos dessa árvore do cristianismo ecoada pelo latim, como o discurso de Santo Agostinho, de São Tomás de Aquino (o discurso da escolástica, cuja força fora estudada por Pierre Bourdieu como referência para a ideia de habitus), de Calvino (cujo impacto foi estudado por Max Weber em "A ética protestante e o espírito do capitalismo"), de Lutero, de Ignácio de Loyola (o espanhol fundador da ordem dos jesuítas), de Erasmo de Roterdã, até aqueles franceses do jansenismo e do humanismo devoto, estudados por Maingueneau ou discursos derivados, que desta vegetação brotaram, feito armas discursivas escolhidas a dedos, como aquele de setores dos jesuítas no Brasil sobre os africanos escravizados no 
Brasil e a maldição de Noé $^{24}$, os indígenas, pegada primava do sistema de educação brasileiro $^{25}$ e nos discursos dos colonizadores do Brasil.

Os jesuítas escrevem nas areias da história do Brasil o referencial monolinguista, advindo do domínio e do poder da instituição Igreja, ainda que manejem esse poder para cooptar discursivamente a diversidade social que os rodeia no Brasil, como o faz com a catequese dos indígenas, dos curumins, mercê da experiência jesuítica na África, na China, na Índia, no contato com povos diversos culturalmente.

Logo, lançam a pedra fundamental das relações raciais no Brasil, em termos discursivos, com um método entre a incorporação e a adaptação ao diferente, desde um ponto de vista de mando inquestionável, diferenças incorporadas na escrita da Língua Geral e sua gramática.

Mas, o reino dos africanos escravizados não é deste mundo, diria Vieira. Pombal correria com o poder jesuíta do Brasil, sem deslocar a posição dos escravizados. A língua conta no discurso do poder de plantão, agora só o português, que como espectro, assombra verticalmente os ares do Brasil de meados do século XVIII em diante, numa gula linguística homogeneizadora sobre o real. Guardadas as devidas proporções, os impérios não deixaram atrás da porta essa arma de guerra de conquista de corpos e mentes: romanos, ingleses, norte-americanos, dentre outros, exemplificam isso.

Já Rabelais ao expor a relevância da cultura popular como íntima de outros horizontes culturais, desloca do palco discursivo da história da humanidade o monolinguismo institucionalizado no discurso latinizado da igreja, relativizando-o, e, na percepção analítica de Bakhtin: o plurilinguismo, que emana do social.

Aflora a dimensão do popular versus as torres de marfins intangíveis, as falas horizontais do meio popular versus os discursos verticalizados que exalam posições institucionais fortes de poder que se pretendem inatingíveis aos comuns dos mortais, mesmo que as proparoxítonas na Península Ibérica tenham pulado primeiro dos livros, das letras, para as bocas das pessoas, para a fala.

Mas, a festa comedida das elites brasileiras brancas nos oitocentos, trazidas nas tintas de Machado de Assis, também embutem o riso e o proibido, mas deixa ver um

\footnotetext{
${ }^{24}$ Andreas Hofbauer, O branqueamento ou o negro em questão. Ver também Sérgio José Custódio, O neobranqueamento no Senado Federal. Em 2013, indicado para a presidência da Comissão de Direitos Humanos da Câmara dos Deputados, o pastor neopentecostal e Deputado Federal Marco Feliciano (Partido Social Cristão - SP), foi acusado de racismo, pois outrora lançara mão de atitude de cunho racista, justamente por referir-se "a maldição de Noé sobre os negros", em seu twitter, ecoando discursos do jesuíta Jorge Benci (já referido e que remete a trechos da bíblia), que na colonização europeia das Américas, era uma das justificativas discursivas para a escravização de africanos e africanas.

${ }^{25}$ Cf. Fernando de Azevedo (1976).
} 
acento discursivo, uma polifonia muda, no silêncio da carta na algibeira, algo mudo que fala. Da glosa de um Vilaça (“um Te Deum”) ao gemido de um menino africano escravizado (“Aí, nhonhô”!).

Isso pode ser enxergado, pela lupa teórica de Authier-Revuz (1982), como uma língua diversificada num dado momento histórico, onde elementos abstratos (palavras, frases) e os "acontecimentos concretos", os enunciados feitos, ganham um sentido, um acento em função do contexto social. De tal modo que, "é em relação aos outros discursos, no "meio" que eles formam e "com" eles, que se constrói todo discurso" (AUTHIER-REVUZ, 1982, p. 36).

Assim, o discurso do silêncio na festa, que apenas aponta a carta na algibeira, e, possivelmente insinua, troca olhares, é uma inequívoca demonstração de poder numa sociedade escravizadora, isso só ocorre em função do seu "exterior constitutivo”, ou seja, o “lugar do 'outro discurso' não é ao lado, mas no discurso, como tecido constitutivo de todo discurso" (AUTHIER-REVUZ, 1982, p. 37). A dimensão dialógica do discurso é um elemento fundamental para a dissertação em curso.

À maneira socrática ${ }^{26}$ das perguntas que geram respostas e novas perguntas, sempre ativas, o ponto de vista de um interlocutor elucida o ponto de vista do outro, pois "a orientação através do meio "exterior" dos outros discursos é um processo constitutivo do discurso, a orientação para um destinatário se marca no tecido do discurso que está sendo produzido" (AUTHIER-REVUZ, 1982, p. 42).

Como isso deságua no interdiscurso, primado sob o qual Maingueneau (2008 [1995]) articula sua Gênese dos Discursos? Ora, pela via da busca de uma relação direta entre os discursos inscritos na história, suas comunidades discursivas respectivas, as instituições que os gerenciam no tempo, e o conflito discursivo instalado entre eles, a inscrição de um discurso no outro, inclusive como imagem ou memória, esse "fator constitutivo do discurso, acrescenta, assim, um parâmetro na produção do discurso no campo do interdiscurso" (AUTHIER-REVUZ, 1982, p. 43).

Depreende-se que uma vez articulada, situada, uma potência explicativa para a heterogeneidade constitutiva, como o visto nos ensaios de Bakhtin e em outros autores mobilizados com grande detalhe e refinamento pela autora, esse dialogismo vira barulho teórico, um passo teórico. Mas, e o Outro do inconsciente lacaniano, onde fica então? Haveria um choque, um estrondo à vista?

\footnotetext{
${ }^{26}$ Como em Platão, O Banquete.
} 


\begin{abstract}
Mas um empecilho radical vem se atravessar entre essas aproximações, que, no entanto, são apenas superficiais: o outro de Bakhtin, aquele dos outros discursos, o outro-interlocutor, pertence ao campo do discurso, do sentido construído, por mais contraditório que seja, em discurso, com palavras 'carregadas de historia'; o outro do inconsciente, do imprevisto do sentido, de um sentido 'desconstruído' no funcionamento autônomo do significante, o outro que abre uma outra heterogeneidade no discurso - de uma outra natureza - que não aquela que estrutura o campo do discurso para Bakhtin, está ausente no horizonte deste. (AUTHIER-REVUZ, 1982, p.p. 43-44 grifo nosso).
\end{abstract}

Como assim, superficiais? Indagaria o leigo. Isso é provável, à medida que se divisa uma intenção lógica de levar a um "fechamento", "bloqueio do dialogismo", remetendo-o exclusivamente ao diálogo externo, numa espécie de leitura tábula rasa de Bakhtin, num grau de interacionismo de tintas meramente retóricas entre o um e o outro no discurso ou vice-versa, na esteira da réplica automática, tréplica etc. Porém, isso não se verifica, pois a força da noção de dialogismo vai mais longe.

Para Authier-Revuz (1982, p. 46), não se pode isolar numa redoma o dialogismo de Bakhtin, num "fechamento" de perspectiva teórica, pois "a bivocalidade interior não pode ser 'esgotada', 'desdobrada inteiramente em um diálogo direto', que tentaria, em uma obra literária, prendê-lo na alternância de réplicas fortemente delimitadas". Por conta disso, a autora propõe mantê-lo na pauta de pesquisa como uma agenda de peso, particularmente na articulação entre "os outros discursos" e "o discurso do outrointerlocutor", mesmo para os estudos em análise de discurso que trabalham com a interlocução e a interdiscursividade. Resta a questão do Outro lacaniano como heterogeneidade.

Uma vez descartada a hipótese do fechamento, abre-se o caminho para a heterogeneidade de outra natureza, aquela "puxada" da psicanálise. Nessa empreitada, a autora atrai Freud, Saussure, Lacan, Descartes, Mallarmé, Roudinesco, Clément, Rimbaud, na intenção de uma amarração teórica em terras estrangeiras para ela, o que só faz explicitar a interdisciplinaridade mobilizada para um belo e sofisticado exercício teórico em linguagem e análise do discurso.

Leitor, leitora, nesse terreno escorregadio, onde os significantes deslizam, importa muito os mantimentos conceituais na mochila do viajante à caça de fundamentos teóricos para uma boa dissertação, para que se possa avançar no entendimento da heterogeneidade constitutiva do discurso. O fulcro é a leitura que Lacan faz da obra de Freud, é dali que a autora extrai sua mais forte sustância teórica:

o inconsciente, a partir de Freud, é uma cadeia de significantes que em algum lugar (em uma outra cena, escreve ele) se repete e insiste em interferir nos 
cortes que lhe oferece o discurso efetivo e a reflexão que ele informa (AUTHIER-REVUZ, 2004 [1982], p. 54).

Estruturando a proliferação dos harmônicos de uma palavra, Lacan dá destaque, seguindo Jakobson, a duas grandes "funções significantes" da linguagem: "a palavra por palavra" da metonímia e "uma palavra pela outra” da metáfora (AUTHIER-REVUZ, 2004 [1982], p. 57 - grifo nosso).

Fica patente que o discurso, digamos "normal", é atravessado pelo inconsciente. É nessa realidade material, nessa matéria-prima - o discurso, em suas variadas situações cotidianas - que ele ressoa. Aqui, merecem destaque duas proposições lacanianas: " $o$ inconsciente é o discurso do outro" e "o inconsciente é estruturado como linguagem" e, mais, o próprio "sujeito é colocado como um efeito de linguagem". Como assim?

Ocorre que, em que pese Freud e Lacan basearem-se, de certo modo, num ponto de vista europeu, eurocêntrico e etnocêntrico, a cadeia de sentido interpretativo para a postulação do estatuto do sujeito parte da homogeneidade de um sujeito consciente pleno, ideal, inteiro, atribuído em Authier-Revuz (2004 [1982]) a Descartes e seu “Cogito, ergo sum" (Penso, logo existo!).

Daí chegar-se-ia a uma heterogeneidade fracionária, por conta destas "feridas narcísicas" vistas, implicando num "descentramento" do sujeito, metido numa espécie de cilada do "mal estar da civilização" por Copérnico, Darwin, "a gaia ciência" ${ }^{27}$, dentre outros fatos históricos típico-ocidentais, onde o eu, perderia sua estatura, seja sua centralidade no universo (natureza), seja nas espécies, passando a conviver com seus "fantasmas" imaginários em seu interior, longe, repita-se, de um confortável ponto fixo do si ou qualquer coordenada cartesiana imóvel que, em tese, poderia ter existido outrora, o que complica, mas complementa, essa dimensão do inconsciente, que atua no corpo mesmo do sujeito, seus sonhos, chistes, atos falhos, esquecimentos.

Emerge daí o Outro também no "tecido interno do discurso", no sujeito descentrado. Importa complementar, nessa visada: sujeito descentrado mais ainda hoje, redescentrado pela própria "crise da psicanálise", da crescente medicalização do cotidiano - dos pés à cabeça - presente nas sociedades, da crise dos discursos teóricos alternativos ao capitalismo, do marxismo, da derrocada da URSS e seus satélites, da crise do capitalismo neoliberal em 2008 que reduziu ainda mais as cabeças já

\footnotetext{
${ }^{27}$ NIETZSCHE (1982): aqui, no aforismo 125, o Homem Louco procura por Deus numa praça pública europeia rodeada pelos doutores da ciência na segunda metade do século XIX. Ao passo que, coetâneo, numa praça pública brasileira, como na cidade do Rio de Janeiro, homens, mulheres, crianças negros(as) e indígenas eram escravizados(as) e vendidos(as), sob os chicotes da ordem social e os latidos de cães "bravos", por fora da lei, mas por dentro dos olhares públicos.
} 
reduzidas $^{28}$, além do raciocínio complementar: colocou mais dinheiro em menos bolsos e, por tabela, ampliou no globo as desigualdades de renda, racial, de gênero, percebidas no chamado ocidente mundial, e de moto mais cruel, em muitas partes do Sul global ou nas disparidades territoriais, como na antiga colônia francesa de São Domingos, no Haiti.

O Outro é o lugar estranho, de onde emana todo discurso: lugar da família, da lei, do pai, na teoria freudiana, elo da história e das posições sociais, lugar a que é remetida toda subjetividade; dizer que o inconsciente é o discurso do Outro é reafirmar, de maneira determinista, que um discurso livre não existe e é dar-lhe a lei (AUTHIER-REVUZ, 2004 [1982], p. 64).

Como articular a heterogeneidade constitutiva do discurso, vista em seus dois ângulos, por dentro do fio do discurso, para a análise do discurso? Num primeiro instante, por meio de um gesto, que nominamos aqui de ruptura epistemológica, qual seja: o abandono definitivo de uma "imagem de um locutor, consciente de um sentido que ele traduz nas palavras de uma língua" (AUTHIER-REVUZ, 2004 [1982], p. 68). Deriva daqui, a aposta, a opção dessa labuta investigativa em análise do discurso pela interdiscursividade $^{29}$,

nenhuma palavra vem neutra "do dicionário"; elas são todas "habitadas" pelos discursos em que viveram "sua vida de palavras", e o discurso se constitui, pois, por um encaminhamento dialógico, feito de acordos, recusas, conflitos, compromissos... pelo "meio" dos outros discursos (AUTHIERREVUZ, 2004 [1982], p. 68).

Porém, um reconhecimento pleno, "do caráter constitutivo e permanente da presença do outro no discurso" torna, com efeito, necessária na análise do discurso, a consideração, na medida do possível, em função das características dos corpora, da observância dessas presenças, o outro e o Outro, no fio do discurso. Já a heterogeneidade mostrada no discurso tem seu próprio estatuto, não sendo manifestação direta da heterogeneidade constitutiva. Há que se ter em conta esses dois planos, e, a complexa negociação entre eles,

assim, as marcas explícitas de heterogeneidade respondem à ameaça que representa, para o desejo de domínio do sujeito falante, o fato de que ele não pode escapar do domínio de uma fala que, fundamentalmente é heterogênea. Através dessas marcas, designando o outro localizadamente, o sujeito empenha-se em fortalecer o estatuto do um. É nesse sentido que a heterogeneidade mostrada pode ser considerada como um modo de negação

\footnotetext{
${ }^{28}$ DUFOUR (2003).

${ }^{29}$ No Brasil independente, no afã de produzir a nova nação, o interdiscurso toma assento na realidade institucional da nação em formação, é assim o embate entre o discurso do constituinte de 1823, José Bonifácio e o outro discurso de Frederico Burlamaqui, de 1837. "Onde José Bonifácio cala, outro antiescravista, aliás, diretor do museu nacional é explícito" (CUNHA, C.; 2012, p. 108).
} 
no discurso da heterogeneidade constitutiva que depende do outro no um (AUTHIER-REVUZ, 2004 [1982], p.p. 73-74).

Desse modo, ao optarmos nessa dissertação pela interdiscursividade como o centro nevrálgico analítico dos discursos presentes nos corpus, busca-se, sim, "acesso a um aspecto da representação que o locutor dá de sua enunciação, o que traduz o modo de negociação com a heterogeneidade constitutiva própria desse discurso" (AUTHIERREVUZ, 2004 [1982], p. 74).

2.3.

Os ventos do interdiscurso.

Daqui em diante, cabe dar passos críticos na direção do que seja interdiscurso, na toada de Maingueneau. Esse autor indica que,

numa primeira aproximação, na perspectiva da "escola francesa de análise do discurso", "discurso" é uma dispersão de textos, cujo modo de inscrição histórica permite definir como um espaço de regularidades enunciativas (MAINGUENEAU, 1995, p. 15).

Mas, isso é só uma aproximação. Um clássico das humanidades francesas, Michel Foucault, filósofo de formação, também conceitua discurso em uma obra clássica,

chamaremos discurso um conjunto de enunciados na medida em que eles decorram da mesma formação discursiva [...] ele é constituído de um número limitado de enunciados para os quais podemos definir um conjunto de condições de existência (FOUCAULT, 1996, p.135).

Maingueneau (1995) reforça as críticas a uma "vulgata estruturalista", consoante à visão de Pêcheux (1982) já expressa. Há que se articular "funcionamento discursivo e sua inscrição histórica", ligar "gênese e interdiscursividade" e "apreender o discurso através da interdiscursividade". "É preciso pensar a discursividade como dito e como dizer, enunciado e enunciação", "um sistema de regras que define a especificidade de uma enunciação". Sem uma metáfora arquitetônica ideal de suporte, um discurso se desdobra em todas as suas dimensões. Aos levantamentos topográficos, típicos de paleontólogos, opõe-se, no processo que ocorre no campo das humanidades, interdisciplinar e conflituoso, por vezes, a identificação, para a análise do discurso, "de um sistema de regras que define a especificidade de uma enunciação". Pontua o autor,

de nosso lado, usaremos o termo "discurso" para referir-nos á própria relação que une a formação discursiva (restrições de boa formação semântica) à superfície discursiva (ao conjunto de enunciados produzidos de acordo com 
esse sistema). Fazendo isso, não nos afastaremos da prática usual dos locutores: evocar "o discurso da arte", o "discurso feminista" etc.. é menos remeter a um conjunto de textos efetivos do que a um conjunto virtual, o dos enunciados que podem ser produzidos de acordo com as restrições da formação discursiva (MAINGUENEAU, 1995, p. 20).

Maingueneau (1995) indica sete hipóteses, que sustentam sua formulação, no esforço de lhe dar consistência teórica: 1) $\mathrm{O}$ interdiscurso tem precedência sobre o discurso; 2) O caráter constitutivo da relação interdiscursiva faz a interação semântica entre os discursos parecer um processo de tradução de interincompreensão regulada; 3 ) Existe um sistema de restrições semânticas globais, que restringe simultaneamente o conjunto dos "planos" discursivos: tanto o vocabulário como os temas tratados, a intertextualidade ou as instâncias de enunciação; 4) O sistema de restrições semânticas é concebido como um modelo de práticas discursivas; 5) $\mathrm{O}$ discurso não deve ser pensado somente como um conjunto de textos, mas como uma prática discursiva; 6) A prática discursiva pode ser considerada como uma prática intersemiótica que integra produções pertencentes a outros domínios semióticos; 7) O recurso a esses sistemas de restrições não implica de forma alguma uma dissociação entre a prática discursiva e outras séries de seu ambiente sócio-histórico.

Fica evidente então, ainda que por vezes sinuosas, que a concatenação perseguida ao longo dessa fundamentação teórica encontra guarida no conjunto dessas hipóteses vistas acima, pois estão presentes as relações entre "discurso e instituição" e relações "entre campos aparentemente heterogêneos", sob o arco da interdisciplinaridade, com eixo central no discurso, na análise do discurso no campo das humanidades.

É patente também a inscrição do autor na pragmática, que persegue uma "articulação entre enunciação e enunciado no ato verbal, linguagem e contexto, fala e ação, instituição linguística e instituições sociais" (MAINGUENEAU, 1995, p. 24).

Não custa frisar que a investigação em construção, apoia-se nos discursos sobre as relações raciais no Brasil, que tiveram origem no processo histórico-político de formação da nação brasileira, independente de Portugal em 1822. Isso se alcança por meio de pesquisas e publicações do campo das humanidades, nos quais se destacam cinco discursos constituintes: o indianismo, o mulatismo, o embranquecimento, a negritude e o discurso dos povos indígenas, que avançam para o século XX e XXI.

Maingueneau (1995, p. 27) dá o devido suporte teórico para esta estratégia, que se insere nos estudos interdiscursivos, 
tem-se liberdade apenas para adotar pontos de apoio heuristicamente interessantes, isto é, de refletir a partir de discursos cuja estrutura e posição na história das ideias e na tipologia dos discursos sejam suficientemente "nodais" para permitir uma difusão em direção às regiões mais diversas.

Instala-se um jogo entre o particular e o universal, pois os discursos selecionados não são todos os discursos sobre a temática, mas pretende-se "falar de alguns pensando falar de todos" e "falar de todos os discursos, falando apenas de alguns".

Ademais, o recorte analítico nessa investigação vai adiante: o que se pretende é verificar indícios da presença dos seguintes discursos: embranquecimento (E1), mulatismo (M2), indianismo (I3), da negritude (N4), dos povos indígenas (PI5), num corpus específico, um conjunto de documentos escritos, situado numa conjuntura, num lugar social e histórico delimitado. Pois, conforme Ginzburg (1976), esses indícios podem revelar preciosa chave de leitura. O corpus, seus textos, podem inclusive mostrar sinais discursivos fundamentais para um reordenamento discursivo, para a emergência de novos discursos, como na hipótese perseguida nessa investigação, a emergência do discurso dos Sem Universidade no Brasil. Adiante nos deteremos mais a fundo sobre os discursos constituintes e o corpus documental particular.

Importa perceber que Maingueneau (1995) fez uma elaboração teórica densa antes de desaguar na interdiscursividade, no interdiscurso como mapa do caminho analítico, na feição que ganharam suas hipóteses de trabalho. Isso ocorreu numa jornada pluridisciplinar, que tinha como batedor a análise do discurso. $\mathrm{O}$ autor dialogou criticamente com G. Genette, Bakhtin, Todorov, Foucault, Dostoievski, Rabelais, M. Serres, Zola, Henri Brémond, Antoine Arnaud, Gadet Conein, Pascal, Tocqueville, Darwin, Lucien Goldmann, Althusser, Michel Le Guern, Mallarmé, Derrida, Freud, Lacan, Pêcheux, Authier-Revuz, Edgar Morin, Racine, A. Schleicher, Michel Serres, R. Jakobson, T. Tynianov, Chomsky, Saussure, Marx, M. Guéroult, A. Jacob, Humboldt, Engels, Ducrot, Bourdieu, Gide, Flaubert, Regis Debray, Kiekegaard, A. Culioli e J.P. Desclés, Michel de Certeau, J.J. Courtine, Panofsky, Victor Hugo, Pierre Bourdieu, dentre outros(as). Isso deixa ver um peso relativo do etnocentrismo, medido pelas ausências: de autores brasileiros, latino-americanos, africanos, indianos, chineses, dentre outros, o que merece essa discretíssima nota crítica.

Antonio Candido (1993, p. 143) refletiu sobre esse ponto minúsculo:

bem dentro do jacobino Aluísio ${ }^{30}$, filho de português, mas antilusitano, como, aliás, dentro da maioria dos intelectuais do tempo, havia um perigoso medo

\footnotetext{
${ }^{30}$ Aluísio Azevedo, autor de O cortiço - livro inspirado em L’Assommoir, de Émile Zola, traduz o Brasil em "miniatura" à partir do Rio de Janeiro de fins do século XIX. Para tanto, vale-se, a seu modo, das
} 
de ser brasileiro, que levava a falar francês, copiar as cartolas inglesas, imitar o estilo acadêmico português, admirar a disciplina alemã e lamentar não houvesse aqui o espírito prático dos norte-americanos.

Para o autor, "quando a Europa diz 'mata', o Brasil diz 'esfola", esse rito organizaria o discurso intelectual no fim dos oitocentos. Tão automático assim, será? Isso remete a alguma espécie de assujeitamento? Surge um nó, mas que é revelador sobre os apetites dos sujeitos para com as opções discursivas que se encontram na prateleira dos discursos num dado momento da história,

\begin{abstract}
quando olhamos mais de perto o que esses intelectuais faziam com as ideias raciais europeias, torna-se claro que eles não eram passivos receptores de ideias produzidas no exterior, meras vítimas de uma mentalidade colonial que procuravam ver sua realidade através de ideias vindas do estrangeiro. Seria talvez mais correto dizer que eles viam aquelas ideias através de sua realidade. A elite branca brasileira já tinha em sua própria sociedade os elementos necessários para forjar sua ideologia racial. Tinha aprendido desde o período colonial a ver os negros como inferiores. Tinha também aprendido a abrir exceções para alguns indivíduos negros ou mulatos. Qualquer europeu ou americano que postulasse a superioridade da raça branca seria necessariamente bem recebido. Ele traria a autoridade e o prestígio de uma cultura superior para ideias já existentes no Brasil. Os brasileiros teriam apenas de fazer alguns ajustes. E os fizeram (COSTA, V., 1998, p. 375).
\end{abstract}

Ladeando o provérbio: muitas vezes a fome discursiva já é maior que a vontade despertada pelos discursos expostos à vista na prateleira dos discursos.

Por outro lado, o assujeitamento, na história dos oitocentos no Brasil, migra do escravizado negro, da escravizada negra, mesmo indígena também, para a "cidadania formal" do pós-abolição. Trata-se de um sequestro do discurso, do direito do Outro social falar: negro, indígena, nordestino refugiado da seca, branco pobre, analfabetizado, como se nota.

Mas a liberdade assim conquistada não se traduziu como vimos, em cidadania política ativa; apenas deslanchou o processo de construção nacional, em que tais indivíduos eram mais assujeitados (GARCIA, 1986) que sujeitos (GUIMARÃES, 2012, p. 36).

Guimarães (2012) contextualiza a questão da evolução da cidadania no Brasil desde um ponto de vista sociológico e troca em miúdos a necessidade de relativização e de esconjurar alguns espantalhos presentes em análises automáticas da realidade brasileira que trocam o cá pelo mundo de lá, como se depreende,

na verdade, se, na Europa, o nascimento num dado território e o compartilhamento de certos traços culturais, como uma língua, comum,

ideias sobre o racismo presentes no quadro do neocolonialismo europeu sobre a África e a Ásia, na segunda metade do século XIX (por exemplo, uma referência nesse sentido é o Congresso de Berlim, de 1885), como informam os escritos, aclamados como científicos à época, de Lapouge e Gobineau, dentre outros. As relações raciais no Brasil aparecem de modo explícito nessa obra ficcional que persegue as bases desses escritos. 
forma condições de primeira hora para a generalização da cidadania no interior dos Estados-Nação; nas Américas, as etnias e posteriormente, a racionalização e percepção das mesmas como raças, passaram a ser justificativas para garantir esses direitos de cidadania e permitir a continuação da escravidão ou do servilismo como modo de produção e como relação de trabalho (GUIMARÃES, 2012, p. 14).

De volta ao mapa teórico de Maingueneau (1995), percebe-se que a abordagem estruturalista e o assujeitamento ficam para trás.

Contudo, nem tanto ao céu, nem tanto ao mar. Foi feito suficiente relativização da questão do assujeitamento vis-à-vis o tema do presente estudo.

Importa também, não achatar qualquer dimensão estrutural presente nas sociedades no geral e na sociedade brasileira em particular, a troco do estruturalismo francês referido na chamada análise de discurso francesa, em grande parte situada na obra de Althusser.

É o caso da noção de classe social, fustigada em muitos setores do mainstream acadêmico ocidental, particularmente no quadro da Guerra Fria (1950-1991), demonizada nos marcos do neoliberalismo dos anos 1990, 2000 e não raro hoje.

Não custa enxergar a importância da classe social para um variado time de autores, de variados continentes, que criaram estudos fundamentais valendo-se desse conceito, muitas vezes alargando-o.

Por exemplo, Thompson estudou a formação da classe operária inglesa; David Ricardo indicou a distribuição de renda entre as classes na economia; Karl Marx alargou a noção até as profundezas da chamada história antiga e indicou o caráter revolucionário da classe trabalhadora frente à burguesia no capitalismo industrial desde meados dos oitocentos na Europa desenvolvida; Max Weber reconheceu a importância deste constructo desde as sociedades modernas; Gramsci agregou uma dimensão cultural ao estudo do fracionamento econômico das sociedades em classes sociais; Pierre Bourdieu complexificou e valorizou o constructo, indicando outras dimensões a ele relacionadas, como o capital cultural, o capital de relações sociais etc.; Milton Santos fez extensa análise conceitual em torno da dimensão territorial e da construção dos espaços geográficos hierarquizados, dentre outros estudiosos, estudiosas, como o indiano Amartya Sen, que explorou a partição assimétrica da justiça e da riqueza nas sociedades em alguns de seus escritos.

Desse modo, classe social é noção relevante neste modesto estudo, e isso carrega uma carga estrutural, como sustenta Guimarães (2012, p. 15-16), 
as classes, enquanto coletivos, formam-se e desfazem-se a depender de conjunturas políticas, mas enquanto estruturas, são permanentes, pois a organização de coletivos sociais é dada pela estrutura socioeconômica e pelo funcionamento do mercado. Vistas como possibilidade de acesso ao mercado de bens e serviços, as classes atuam permanentemente, ao definir as chances individuais através da posse de seus capitais e de seus marcadores (BOURDIEU, 1979). A propriedade de ativos financeiros e de imóveis, o domínio da norma culta da língua materna, de línguas universais, de códigos da cultura erudita, a posse de conhecimento científico e de credenciais escolares etc. constituem, pois, elementos permanentes de classificação social e de distinção a relativizar a equalização dos indivíduos em cidadãos. Nas Américas, as classes sociais seguem historicamente um recorte muito próximo aos dos povos que aqui se encontram (e se mesclam) e que são referidos como raças. A mestiçagem pode confundir essas fronteiras ou acentuá-las. O decisivo para esse jogo classificatório é o modo como se constitui a cidadania, ou seja, a igualdade de direitos entre os indivíduos que compõem a nação. Como as hierarquias sociais se mantêm e se reproduzem no contexto ideológico republicano?

Responde o próprio autor "a subcidadania da maioria dos negros e mestiços evitou por muito tempo que as raízes raciais da hierarquia social fossem visíveis" (GUIMARÃES, 2012, p.16).

Importa incluir aqui: subcidadania também de indígenas, mesmo de brancos pobres, de massas humanas analfabetizadas no geral e das massas excluídas da educação pública formal de qualidade em todos os níveis, da creche à pós-graduação, pela ausência de um sistema nacional público de educação, ao contrário do visto no chamado Estado de Bem-Estar Social europeu na idade de ouro do capitalismo na segunda metade dos novecentos.

Desponta aqui com agudeza a exclusão da universidade no Brasil, o caso histórico dos Sem Universidade, $99 \%$ da população em 1962, como indicou a peça "O auto dos 99\%". Só 9\% estavam nas universidades em 2003, depois 18\% em 2014.

Mas, as pistas da busca por cidadania negada no Brasil, depois da abolição, onde "todos são cidadãos formais", ao menos precisa ser ouvida como uma grita discursiva por direitos que varre o tempo, para espantar noção espetacularizada "do sono do povo em berços esplêndidos" e dos "gigantes que são acordados conforme a música doce aos ouvidos", que assim esconde no além, muito sangue derramado por direitos no Brasil.

Cabe destacar, sem excluir outros episódios e movimentos, menores ou maiores, locais, regionais, nacionais ou não, mas igualmente relevantes: a Guarda Negra e o Isabelismo; a reforma agrária para os libertos - projeto do abolicionista monarquista negro André Rebouças; a entusiasta ação contra a escravidão do rábula negro Luiz 
Gama, ele próprio um ex-escravizado nos oitocentos, a Guerra de Canudos, entre 1896 e 1897; a revolta popular da vacina, de 1904; a revolta contra a Chibata, de 1910; a Guerra do Contestado, nos anos 1910; a campanha pela posse do negro Monteiro Lopes como Deputado pelo Rio de Janeiro em 1909; a criação da imprensa alternativa negra em São Paulo e Campinas, nos anos 1910; o surgimento do Serviço de Proteção ao Índio (SPI), comandado pelo indígena Rondon, nos anos 1910; a luta dos quilombolas, população remanescente de quilombos; o desenvolvimento da Frente Negra Brasileira, de 1931 a 1937; o movimento nacional dos entusiastas pela educação pública nos anos 1920; o manifesto dos pioneiros da educação em 1932; a criação do Teatro Experimental do Negro (TEN), com forte ação educativa nos anos 1940/1950, sob a liderança de Abdias do Nascimento e a ação política de intelectuais negros como Solano Trindade e Guerreiro Ramos; a luta da educação popular contra a analfabetização no Nordeste com os centros de cultura, sob a liderança de Paulo Freire, nos anos 1940/1950; o Manifesto em Defesa da Escola Pública e a luta pela criação da Lei de Diretrizes da Educação Brasileira nos anos 1950/1960; a luta por Reforma Universitária Popular no período Goulart; a luta dos excedentes por vagas em universidades públicas - pessoas que eram aprovadas, mas ficavam em listas de espera por vagas nos anos 1960; o surgimento do Movimento Negro Unificado Contra a Discriminação Racial (MNU) nos anos 1970; a organização difusa do movimento negro no processo constituinte de 1988; a articulação dos povos indígenas brasileiros no processo constituinte de 1988 (Há que se pontuar a presença de outros movimentos sociais nos anos 1980, tais como: o novo sindicalismo, o Movimento dos Trabalhadores Rurais Sem Terra - MST, o movimento ambientalista, o movimento feminista, a Central de Movimentos Populares- CMP, a Comissão Pastoral da Terra - CPT, o Movimento Nacional de Meninos e Meninas de Rua, o movimento pelos direitos da diversidade sexual, dentre outros de enorme importância para a história do Brasil); o Fórum Nacional em Defesa da Escola Pública, no processo constituinte de 1988; os Congressos Nacionais de Educação (CONEDs) nos anos 1990/2000, bem como o surgimento de miríades de organizações da sociedade civil em amplíssimos setores sociais, o que se verificou empiricamente no começo dos anos 2000 nas edições do Fórum Social Mundial em Porto Alegre.

É pertinente sobremaneira, para o escopo dessa investigação, o caso de organizações de combate ao racismo e da defesa da igualdade racial, como a CONEN (Coordenação Nacional das Entidades Negras), de defesa dos povos indígenas, da 
escola pública; a centralidade da luta pelo direito à universidade no Brasil, com o aparecimento do MSU, Movimento dos Sem Universidade, por exemplo.

Nesse mundo nada plano que corre no tempo desde a abolição inconclusa, um mundo que passou por três perfis de repúblicas (1989-1930; 1945-1964; 1985-2014), duas ditaduras (1937-1945; 1964-1985), a ascensão da luta de massas por cidadania e direitos sociais negados - nos anos 1980, a resistência ao tsunami neoliberal nos anos 1990 e os ensaios pós-neoliberalismo dos anos 2000 com avanços sociais relativos, mas inéditos na história do Brasil, neste quadro histórico dinâmico, instala-se uma complexa trama discursiva, no geral, favorecendo a reprodução de uma das sociedades mais desiguais do planeta Terra.

Em que medida o interdiscurso dá conta disso? Em que medida serve para identificar a repetição ou recalibragem dos discursos dominantes, encarregados da manutenção do status quo e por tabela, dos discursos que buscam a negação dessa ordem? Como o interdiscurso se sustenta numa sociedade que deixa tardiamente de ser rural (anos 1950), torna-se de industrialização tardia (anos 1930-1980) e por fim, organiza a produção da riqueza material concentrando o grosso de sua população na atividade de serviços (cerca de $70 \%$ das ocupações em 2013)? Onde se situa o interdiscurso frente uma ordem global fortemente dominada estruturalmente por um capitalismo financeirizado como nunca se viu?

Se não tem cunho determinista nos discursos, as estruturas históricas e suas heranças, econômicas e suas heranças, sociais e suas heranças, contam de algum modo nos discursos.

Além disso, o debate caro à Authier-Revuz (1982), como o Outro da psicanálise, é deixado num palco ${ }^{31}$ particular. Anuncia-se, em parte, uma ultrapassagem ${ }^{32}$, "o primado do interdiscurso inscreve-se nessa perspectiva de uma heterogeneidade constitutiva, que amarra, em uma relação inextricável, o Mesmo do discurso e seu Outro" (MAINGUENEAU, 1995, p. 31).

\footnotetext{
${ }^{31}$ Um provável indicativo aqui, talvez seja que o Outro da psicanálise ocupe um palco particular, no sentido de ser o lugar onde esteja todos os significantes, um lugar mítico, porto do grande Outro, como fala Lacan no Seminário XI. Contudo, sobre esse palco Maingueneau é econômico e essa dissertação não avançará, infelizmente, na direção dessas paragens.

32 Dessa maneira podemos esperar ir além da distinção entre heterogeneidade "mostrada" e heterogeneidade "constitutiva", revelar a relação com o Outro independentemente de qualquer forma de alteridade marcada (MAINGUENEAU, 1995, p. 37).
} 
É numa espécie de discurso primeiro que se encontra o constitutivo do discurso segundo $^{33}$. Contudo, o autor, assim como Authier-Revuz (1982), valoriza e reconhece a heterogeneidade constitutiva nos "precursores", no dialogismo de Bakhtin, porém enxerga limites e peças teóricas soltas nestes ensaios linguajeiros e busca dar um passo adiante, na busca teórica por refinamento, um sistema analítico inovador e mais delimitado,

Se, em algum sentido, nosso percurso se inscreve na mesma perspectiva que a de Bakhtin, a de uma "heterogeneidade constitutiva", operaremos, no entanto, em um quadro restrito, atribuindo a essa orientação geral um quadro metodológico e um domínio de validade muito mais preciso (MAINGUENEAU, 1995, p. 33).

Avança o autor (MAINGUENEAU, 1995, p.33), "interdiscurso é uma tríade: universo discursivo, campo discursivo e espaço discursivo". O universo é "o conjunto das formações discursivas ${ }^{34}$ que interagem numa conjuntura dada". O campo perfaz "um conjunto de formações discursivas que se encontram em concorrência, delimitamse reciprocamente em uma região determinada do universo discursivo", ou seja, podese pensar em campo político, científico, religioso, gramatical etc. Assim como, em conflito, aliança ou neutralidade entre os campos. Não sendo insulares, entretanto, são as fontes dos discursos:

é no interior do campo discursivo que se constitui um discurso, e levantamos a hipótese de que essa constituição pode deixar-se descrever em termos de operações regulares sobre formações discursivas já existentes. O que não significa, entretanto, que um discurso se constitua da mesma forma com todos os discursos desse campo; e isso em razão de sua evidente heterogeneidade: uma hierarquia instável opõe discursos dominantes e dominados e todos eles não se situam necessariamente no mesmo plano. Não é possível, pois, determinar a priori as modalidades das relações entre as formações discursivas de um campo (MAINGUENEAU, 1995, p. p. 34-35).

No estudo de Maingueneau sobre correntes do catolicismo francês no século XVII, ao invés de optar pela escolha de um campo religioso ou de reduzir sua análise do discurso a um monológico-absoluto bíblico, ele divisou, arbitrou um discurso "humanista devoto" e outro "jansenista" para sua empreitada.

Para os desafios dessa investigação em curso, arbitra-se que os discursos constituintes conformam o campo das "relações raciais" (desde o Brasil independente),

\footnotetext{
${ }^{33}$ Todo campo discursivo define certa maneira de citar os discursos anteriores do mesmo campo. A maneira segundo a qual um físico moderno se refere a Galilei ou a Newton não é comparável à maneira pela qual um discurso católico se reporta à produção de São Paulo. Mas, ao lado dessas restrições compartilhadas pelos diversos membros de um campo, há também o passado específico que cada discurso particular constrói para si, atribuindo-se certas filiações e recusando outras (MAINGUENEAU, 1995, p. 77-78).

${ }^{34}$ Conforme Michel Foucault, em Arqueologia do saber.
} 
aí se inserem, não de modo exclusivo, mas sim, relativizando-se com outros campos discursivos, como o campo político.

Desse modo, pretende-se sustentar uma forte argumentação que possibilite a identificação no corpus particular, um conjunto de documentos do ano de 2003, da presença dos discursos do embranquecimento (E1), do mulatismo (ML2), do indianismo (I3), da negritude (N4) e dos povos indígenas (PI5), como referências para a assunção de novos sujeitos sociais no Brasil: os Sem Universidade.

São variadas as razões para justificar esta escolha teórica, onde desponta a hipótese da hierarquização e privilégio racial e social no Brasil para o acesso à universidade, outrora nos oitocentos, como em 2003 e hoje em dia no Brasil em escala considerável.

Decorre por fim a noção de espaço discursivo. O que é conceitualmente? Tratase de categoria teórica que pode ser compatível com a ideia de campo de Bourdieu (1983). Por exemplo, num dado campo discursivo, como o campo educacional, instalam-se disputas de poder entre os agentes conforme sua posição e força. Se a posição do agente é periférica no campo, isso significa que sua posição não é dominante.

Assim, pode-se falar em campo discursivo para uma dada configuração dinâmica do jogo discursivo. Não é impossível, mas é difícil o desenvolvimento de estudos com abrangência suficiente para envolver todos os discursos de um dado campo, e muito improvável, estudos que juntem campos completos em relação com outros campos ou mesmo o conjunto todo de campos, o universo discursivo.

Por isso, ganha importância o conceito de espaço discursivo, como lócus por excelência da materialidade discursiva, trata-se de um subconjunto do espaço discursivo. Caracteriza-se como um recorte do campo discursivo.

Neste estudo, pode-se falar em campo discursivo das relações raciais no Brasil, por exemplo. Mas, isso seria gigante.

Em função disso buscou-se desenhar um espaço discursivo das relações raciais no Brasil, partindo-se de pelo menos dois discursos, pois se havia o "senhor de escravos" e a lei a seu favor, havia também o escravizado negro, indígena, então havia o discurso dos que mandavam e o discurso dos que eram forçados a obedecer, ambos inscritos na história do Brasil no processo de sua construção autônoma como nação.

Mas, esse quadro implica em maiores empenhos analíticos, o que não é simples, requer opções e investidas investigativas. E também não se trata da procura por uma 
ilha discursiva artificial isolada do continente discursivo e das disputas na atmosfera discursiva e suas dinâmicas no tempo.

Por exemplo, a Revolução Malês, na Bahia, em 1835, foi organizada por negros escravizados africanos muçulmanos e revela um discurso negro contra o status quo da época. A definição da manutenção da escravização de africanos e de africanas na carta constitucional originária do Brasil, outorgada por Dom Pedro I em 1824, revela outro discurso.

A opção feita neste estudo em curso, entretanto, elegeu como base para a construção de um espaço discursivo das relações raciais no Brasil - não é o único possível - o estudo seminal de Von Martius publicado pelo IHGB em 1845, seus desdobramentos e suas lacunas. Desse estudo derivam, na leitura indicada por Guimarães (2012) dois discursos: o embranquecimento e o mulatismo.

Mas, como o ocorrido com a Revolução Malês na Bahia, silenciada com mortes e perseguições, o quadro da escravização negra, do ponto de vista de uma identidade negra e da luta negra, é marginalizado em Von Martius. Essa espécie de lacuna é “coberta" pela aparição em Guimarães (2012) do discurso da negritude, que ganha outra dimensão nessa dissertação, ao ter seu horizonte ampliado, não ficando restrito ao episódio dos anos 1940/1950 que o autor aponta no artigo supracitado, nem nos limites conceituais ali expostos, o que se verá mais a frente. Assim, conformam-se três discursos e de saída duas lacunas seriíssimas: o discurso do status quo sobre os indígenas e o discurso dos próprios indígenas. O que fazer?

Em socorro aparecem os estudos de Carneiro da Cunha (2012), que abordam a mesma época de Von Martius, indagando especificamente sobre a questão indígena.

De tal forma que, complementarmente, fecha-se um espaço discursivo sobre as relações raciais no Brasil com cinco discursos: o discurso do embranquecimento, o discurso do mulatismo, o discurso da negritude, o discurso do indianismo e o discurso dos povos indígenas. Esses discursos serão especificamente desenvolvidos oportunamente.

No espaço discursivo, instala-se um jogo, uma disputa discursiva. Isso está presente na sociedade dinamicamente e envolve discursos de antes e depois, atualizações discursivas.

No Brasil, já nos primeiros anos dos novecentos, o jogo das heranças raciais e sociais informa registros autênticos do interdiscurso, 
a preta Quitéria engendrou vários filhos. Os machos fugiram, foram presos, tornaram a fugir - e antes da abolição já estavam meio livres. Sumiram-se. As fêmeas, Luísa e Maria, agregavam-se à gente de meu avô. Maria, a mais nova, nascida forra, nunca deixou de ser escrava. E Joaquina, produto dela, substituiu-a na cozinha até que, mortos os velhos, a família não teve recurso para sustentá-la. Aí Joaquina se libertou. E casou, diferençando-se das ascendentes. Luísa era intratável e vagabunda. Em tempo de seca e fome chegava-se aos antigos senhores, instalava-se na fazenda, resmungona, malcriada, a discutir alto, a fomentar a desordem. Ao cabo de semanas arrumava os picuás e entrava na pândega, ia gerar negrinhos, que desapareciam comidos pela verminose ou oferecidos, como crias de gato. Parece que só escaparam os dois recolhidos por meu pai. A moleca Maria... O moleque José... (RAMOS, 1995 (1945), p. 75).

Nesse jogo geracional, passado o tempo, as violências das relações raciais no Brasil desfilam nas vozes e nos corpos. Para Maingueneau (1995), o interdiscurso não é o que fora definido na abordagem do discurso estruturalista francês, na qual os intradiscursos eram pretensamente compactos, fechados e se relacionavam entre si nessa métrica. Para o autor, faz-se necessário "subverter essa equivalência entre exterior do discurso e interdiscurso, para pensar a presença do interdiscurso no próprio coração do intradiscurso".

E, esmiuçar as distinções entre o outro (da interlocução dialógica); o Outro (da psicanálise lacaniana), que operaria em outro "palco", o que dá toda a carga semântica presente no constructo do autor e o Outro (homônimo) do interdiscurso,

no espaço discursivo, o Outro não é nem um fragmento localizável, uma citação, nem uma entidade externa; não é necessário que ele seja localizável por alguma ruptura visível da compacidade (qualidade daquilo que é compacto) do discurso. Ele se encontra na raiz de um Mesmo sempre já descentrado em relação a si próprio, que não é em momento algum passível de ser considerado sob a figura de uma plenitude autônoma. Ele é aquele que faz sistematicamente falta a um discurso e lhe permite encerrar-se em um todo. É aquela parte de sentido que foi necessário o discurso sacrificar para constituir a própria identidade (MAINGUENEAU, 1995, p. 37).

O autor (MAINGUENEAU, 1995, p. 37) sustenta que "a relação constitutiva é marcada por poucos índices na superfície discursiva".

Desta perspectiva, num cordel, típico discurso da cultura popular brasileira, nordestina, um gênero do discurso, se assim se deseja, ou, um documento histórico ${ }^{35}$, a presença de Virgulino Lampião, ou não, da figura do Coronel, ou não, informa índices do discurso do poder estabelecido (da ordem) ou índices do discurso à margem da ordem social nordestina, num dado contexto, como os anos 1930 no Brasil.

\footnotetext{
${ }^{35}$ Os primeiros folhetos de cordel surgiram após a invenção da prensa móvel no século XVI. A tradição de contar histórias com versos rimados veio para o Brasil graças aos portugueses. Apesar de ter sido inventada há alguns séculos o Cordel como história do Brasil é parte da historiografia brasileira.
} 
Maingueneau vai adiante. Ao utilizar a metáfora do palco, o que remete ao teatro, ao mundo cênico, está tecendo sua fiada teórica com maestria. Assim, avolumam-se as fichas nas mãos do construtor de uma teoria para a gênese dos discursos. Mas, pé no freio. Não são todos os palcos finitos ou infinitos.

De fato há um intento liminar e subliminar aqui, na continuação desta fundamentação teórica. O Brasil não é a França. Isso importa para a temática investigada, daí essas aparentes encruzilhadas, o labirinto ${ }^{36}$ teórico em movimento.

Se a República francesa entoou o canto dos direitos do homem, um discurso universal, ao nascer, mas não tolerou a revolta dos escravizados africanos do Haiti, a República brasileira, também entoou discursos universais, como o positivismo de Comte ao nascer, mas não tolerou a organização popular e multicultural do Arraial de Canudos, de Antonio Conselheiro, pois temia o povo e buscou dizimá-lo, como descreveu Euclides da Cunha, no clássico da cultura brasileira "Os Sertões".

Nesse caso, também a noção de hierarquia racial criada por autores europeus de então é apropriada pelo autor, e, perplexo, ao mesmo tempo em que viu no "sertanejo, antes de tudo, um forte", curvou-se àqueles discursos raciais ao apontar o dedo e nomear a "sub-raça", a "raça inferior" que abundava sob seus olhos em Canudos: pobres, negros, indígenas. Em 1994, o grupo de rap de Brasília Câmbio Negro, entoaria o rap "Sub-raça", numa batida forte contra esse discurso que aparece em "Os Sertões" e não apenas ali.

Se o discurso da República, um discurso constituinte universal, tem funcionalidade para ser apropriado em textos, como a Constituição da França da Revolução Francesa ou a Constituição do Brasil República de 1891, a relação entre os discursos inscritos na história é perturbada por "práticas discursivas", que emergem em situações históricas específicas, mas tem o condão de tensionar os discursivos constituintes, em particular os universais, pela evidente contradição entre discurso e prática. No Haiti ou em Canudos “os homens são todos iguais"? ${ }^{37}$

\footnotetext{
36 "Isso quer dizer que a ordem de sucessão dos "planos" que seguimos em nossa apresentação é completamente arbitrária no que diz respeito ao "esquema construtor" global representado pela competência discursiva que os investe. Não constitui de forma alguma um modelo genético em virtude do qual o enunciador escolheria previamente um tema, depois um gênero literário, depois um vocabulário etc...A própria lista desses planos considerados não é objeto de uma elaboração teórica suficiente para pretender definir um modelo de textualidade. Sua única fidelidade é ilustrar a variedade das dimensões abarcadas pela perspectiva de uma semântica global, e nada impede de isolar outras ou de repartir diferentemente as divisões propostas" (MAINGUENEAU, 1995, p. 77).

${ }^{37} \mathrm{O}$ discurso dos dominados de Canudos, por meio de uma planta do lugar, dos sertões baianos, a favela, levada por soldados do Rio de Janeiro que participaram da Guerra (A) Canudos, e, que, depois, seria plantada nos morros do Rio de Janeiro, encontraria uma espécie de herança histórica no próprio nome
} 
O discurso dos dominados de Canudos, por meio de uma planta do lugar, dos sertões baianos, a favela, levada por soldados do Rio de Janeiro que participaram da Guerra (A) Canudos, e, que, depois, seria plantada nos morros do Rio de Janeiro, encontraria uma espécie de herança histórica, no sentido de discursos que emergem do que é chamado de margem da sociedade brasileira, um caso estranho e talvez raro.

Nessa cena, muitas vezes se esquece do quanto não é também margem, do quanto há de inserção subordinada da favela no social, seja nas cozinhas ou nas portarias dos prédios de classe média ou alta, seja como as empregadas domésticas negras, os porteiros negros. Como diz muitas letras de rap sobre a "alegria na favela" ou o cancioneiro popular brasileiro desde a canção "Barracão de zinco" até Chico Buarque de Hollanda, em Brejo da Cruz, "eram crianças e comiam luz", num apelo poético pela igualdade social no Brasil.

De volta nas pegadas do espaço discursivo.

Nesses espaços discursivos as cenas se aparentam a "conflitos regulados" pelos discursos e não só. Pontua Maingueneau (1995, p. 35),

reconhecer esse tipo de primado do interdiscurso é incitar a construir um sistema no qual a definição da rede semântica que circunscreve a especificidade de um discurso coincide com a definição das relações desse discurso com seu Outro.

Ao campearmos um espaço discursivo particular no campo discursivo das relações raciais no Brasil e o acharmos (como o visto), ato contínuo é enveredarmos pela rede de sentidos, sua legitimidade, sua duração e conservação, como estrada mesmo para a vida ou morte dos discursos constituintes.

O sociólogo Florestan Fernandes em "A Integração do Negro na Sociedade de Classes" percebeu o longo movimento da sociedade nomeada de castas da casa-grande e senzala para a sociedade de classes do século XX, Octávio Ianni estudou "as metamorfoses do escravo", para captar as mudanças da condição social dos negros da escravidão brasileira para a República brasileira. Assim, cabe a pergunta: pode-se falar também em metamorfoses dos discursos constituintes sobre as relações raciais no correr da história do Brasil do século XIX para o século XXI?

Contudo, se a cena social histórica perpetua no tempo as desigualdades raciais, sociais, logo o chão para o teste de força dos discursos constituintes e seus derivados continua fértil. No caso brasileiro, a abolição da escravidão de 1888 tinha duas notas

favela, que passaria a nomear os morros do Rio de Janeiro, de onde lutas incríveis emergiram. Caso raro, onde a planta carrega a história. 
só: 1) declara-se extinta a escravidão no Brasil; 2) Revogam-se todas as disposições em contrário. Nada se disse sobre o direito ao voto e a ser votado, à educação, a universidade, a terra, a casa, ao trabalho. Um silêncio ensurdecedor, pois. Em 1988, cem anos depois, o direito ao voto chegará aos analfabetizados. É nessa Constituição de 1988 que o negro e o indígena, enquanto sujeitos de direito, aparecem na letra da lei e problematizam o discurso da igualdade universal, reivindicando-o, inclusive.

Ou seja, o Outro insiste em sua sobrevida, num estado de latência, mas quando a ocasião tensiona por direitos historicamente negados, o interdiscurso desperta, ordenando o espaço discursivo, como o é o caso das cotas nas universidades públicas paulistas.

Pois se há uma lei nacional aprovada pelo Congresso Nacional, em função da luta do movimento negro, do movimento indígena, do movimento em defesa da educação pública (Lei 12.711/12), do MSU, por que o caso nacional não pode valer para as universidades estaduais paulistas?

Sem pés descalços, sem correntes nas mãos nem ferros no pescoço, no entanto, essa carga semântica do genocídio negro do Brasil aparece, de repente, numa manifestação pró-cotas (de negros, indígenas e brancos) em universidades públicas no Congresso Nacional, na encenação de uma batida policial na parede em frente à sala de reuniões ordinárias da poderosíssima Comissão de Constituição e Justiça do Senado Federal, feita pelo MSU em 2009, ou na estatística fria do número de jovens negros assassinados nas periferias por cem mil habitantes, dois de cada três, conforme o mapa da violência no Brasil em 2011.

Instala-se em plenitude o conflito entre os discursos constituintes. "Raça não existe", diria em 2009 o então presidente da Comissão de Constituição e Justiça do Senado Federal, o Senador Demóstenes Torres, líder político então da coalizão social brasileira contra a aprovação da Lei de Cotas para o acesso à universidade pública federal no Brasil, que se considerava branco, mas descendente de mulatos e admirador de Gilberto Freyre. Na prática, buscava branquear o PLC 180/08, para não aprová-lo.

Eis traços do discurso do afamado Senador no STF:

Confesso a Vossa Excelência que fui eu mesmo que incitei o meu partido a vir aqui buscar uma definição do Supremo Tribunal Federal, porque é uma responsabilidade extraordinária; é uma responsabilidade do Congresso (TORRES, 2010, p. 119).

As negras foram estupradas no Brasil. A miscigenação se deu pelo estupro. Foi algo absolutamente forçado. Gilberto Freire, que hoje é completamente renegado, mostra que isso se deu de uma forma muito mais consensual e que, 
felizmente, isso levou o Brasil a ter hoje essa magnífica configuração racial (TORRES, 2010, p. 129).

Maingueneau (1995, p.p. 40-41) subscreve,

o espaço discursivo tem então um duplo estatuto: pode-se apreendê-lo como um modelo dissimétrico que permite descrever a constituição de um discurso, mas também como um modelo simétrico de interação conflituosa entre dois discursos para os quais o Outro representa totalmente ou em parte seu Outro. É esse último aspecto, o de um processo de dupla tradução, que vai nos interessar essencialmente. Na realidade, as coisas são mais complexas e devese distinguir para o discurso segundo uma fase de constituição e uma fase de conservação. Nesta última fase, mesmo que a presença do Outro constitutivo tenha desaparecido, a maneira pela qual o discurso segundo vai gerir suas novas relações interdiscursivas continua determinada pela rede semântica através da qual ele se constitui: situações e protagonistas podem variar, mas eles serão analisados pela grade original, a mesma que assegura a identidade da formação discursiva. Tal permanência se explica melhor se distinguirmos o desaparecimento de um discurso de sua marginalização e da redistribuição de sua área semântica. De fato, na maioria das vezes, o discurso não desaparece, seus suportes não se dissipam brutalmente, mas ele recua para a periferia, ou, situação na qual pouco se pensa, a área semântica que ele recobria é total ou parcialmente retomada por outra, ou redistribuída entre várias. Em outras palavras, se o discurso segundo não tem mais nada a ver com o discurso primeiro, nem por isso ele necessariamente deixa de ter relação com as estruturas semânticas correspondentes, nas quais continuará a ler a figura de seu Outro.

Caso o andar da investigação faça emergir transformações do sistema semântico para o caso em estudo, mesmo assim, impõem-se restrições semânticas, sob o risco do deslocamento do interdiscurso no seio do campo discursivo, uma espécie de desordenamento do espaço discursivo enquanto rede semântica.

Fica evidente nesta fundamentação teórica que tais restrições semânticas, verdadeiros parâmetros analíticos dos interdiscursos, distanciam-se de uma noção de aplicação de uma lei universal dura, como se fosse uma espécie de física a operar uma lei teórica da mecânica newtoniana nos estudos do discurso. Assim, o autor reforça essa percepção já destacada em Pêcheux (1982) e Authier-Revuz (1982).

Acrescenta-se a isso, novas demarcações de cunho metodológico e epistemológico, trazidas também pelo autor. Ao passo que Authier-Revuz (1982), instala um jogo teórico para além das fronteiras da linguagem, ao decidir "puxar" a psicanálise e o dialogismo bakhtiniano, para melhor robustecer seus constructos teóricos, quais sejam: a heterogeneidade mostrada e as heterogeneidades constituintes (o outro, do dialogismo e o Outro da psicanálise lacaniana), Maingueneau (1995) vai além.

Ele deixa claro uma valoração intersemiótica, necessária para que fique em pé sua base teórica, o que pode nomear-se de jogo intersemiótico, para que a percepção dos sentidos do discurso se mostre em sua potência maior. 
Por isso, a presença das artes plásticas em sua análise dos interdiscursos do jansenismo versus o humanismo devoto, como os quadros "Os peregrinos de Emaús, de Ticiano e "Ceia de Emaus", atribuído a J.". B. Champagne, desanuvia o conflito aparente interdisciplinar, na direção da ampliação da cena discursiva, enredada pela análise do discurso pela via do interdiscurso, no campo das humanidades, além dos textos.

A semiótica do corpo e a prática social são outras dimensões muito relevantes na perspectiva do autor. Os quadros, o corpo e a prática social podem ser indicativos objetivos de materialização de um jogo semiótico interdiscursivo particular instalado num dado espaço discursivo peculiar, numa certa conjuntura histórica.

\section{4. $O$ constructo do quadro de restrição semântica da competência discursiva ampliada.}

Ao postular uma relação entre discurso e história, seja um "isomorfismo" ou "esquemas de correspondência", Maingueneau (1995) decide enfrentar uma verdadeira pedreira teórica. Ocorre que, era a ideia de "ideologia", quase que um lugar- comum, que fizera essa solda, usada até não mais poder, nos primórdios da análise do discurso de linha francesa, de modo marcante nos estudos dos discursos políticos conduzidos por Althusser, como parte da leitura estruturalista em análise do discurso, visão que o autor decide não entoar, apesar de reconhecer sua centralidade para discursos específicos.

Por outro lado, Foucault também fizera esse exercício solo, ao desviar de termos como "ciência" e "ideologia" na costura de seu clássico "Arqueologia do Saber", onde sai à procura das formações discursivas. Filósofo e em algum grau excêntrico, mesmo de posse tácita de elementos da história da medicina, da gramática e da economia política, Foucault faz do "anônimo" sua âncora mais profunda para tecer a assunção ao mundo ocidental destes campos do saber.

Maingueneau (1995) entende como salutar e bastante desafiadora essa via, porém compreende a necessidade de perscrutar mais, quem sabe, no intento de encontrar um conjunto de regras para um caso geral, hipotético, uma teoria para os discursos de uma maneira geral, um sistema. 
Em Noam Chomsky e sua formulação linguística da existência de uma "gramática gerativa", de cunho universal, comum aos falantes, aos usuários da língua, qualquer que seja ela, Maingueneau (1995) divisa a possibilidade de algum paralelismo para uma empreitada teórica no campo discursivo, articulando talvez, aquilo que nominara de peças soltas do dialogismo, do chamado círculo de Bakhtin (1920-1975).

Para o autor, não se trata de concordar com a teoria de Chomsky, que no limite, remeteria ao mistério, a algo inscrito no DNA das pessoas, na língua. Contudo, a dimensão "genética", de "origem", esse leitmotiv, poderia ser um bom fermento para fazer crescer uma urdidura teórica para a gênese dos discursos.

Dito e feito. Maingueneau (1995) vira as costas para o empírico e move suas alavancas no campo abstrato, sem maniqueísmos simplistas, diga-se, para superar seu desafio: fazer brotar uma teoria do interdiscurso, da origem dos discursos, com base em semas abstratos, advindos da língua, "um código à priori", sob o domínio da cultura, carregados de sentido, de potência ordenadora, quando submetidos a uma função de tradução desta bateria semântica inicial, dessa biblioteca semântica básica abstrata, para os campos discursivos arbitrados pelo analista do discurso, para os espaços discursivos empíricos: "seria mais verossímil postular que existe uma relação entre a simplicidade do sistema de restrições do discurso e a possibilidade de dominá-lo”.

Pois, pela óptica do interdiscurso, os discursos estão necessariamente polarizados, onde os semas ganham denotação positiva ou negativa, conforme o quadro discursivo de interincompreensão em análise, em jogo, no confronto dos discursos, que perpassa os tempos, variada gama de suportes, e tem também um registro multidimensional, como plurissemioticidade, através dos "múltiplos dispositivos acessíveis à enunciação".

O autor chama esse constructo teórico de competência discursiva ${ }^{38}$, necessariamente inscrita na história, não etérea, mas de caráter sistêmico. Atento ao movimento de mundialização, globalização, suas contradições e possibilidades discursivas, as situações novas de comunicação de massa, como a potência intersemiótica da internet, ao mesmo tempo texto, imagem, som etc., Maingueneau (1995, p.p. 50-51) afirma,

\footnotetext{
${ }^{38}$ Para o autor, "O princípio de uma competência discursiva permite esclarecer um pouco a articulação do discurso e a capacidade dos Sujeitos de interpretar e de produzir enunciados que dele decorram", (MAINGUENEAU, 1995, p. 52).
} 
o tipo de discurso que visamos de maneira privilegiada produz enunciados que influenciam de maneira mais imediata a experiência de vida de grandes camadas de população. Mesmo sendo numerosos, seus autores não vão além de um subconjunto restrito de inúmeros outros enunciadores, dos quais, através de seus escritos, são ao mesmo tempo o eco e o suporte.

No geral, essa "competência discursiva" é que faz a governança dos discursos num dado campo discursivo, num dado espaço discursivo e seus enunciadores, trata-se de um "sistema de restrições semânticas único", o que não deve ser tomado como uma espécie de função linear, um fechamento discursivo puro e simples.

É possível, inclusive, baseado nessa restrição semântica, a emergência de enunciados inovadores, inéditos e, mesmo de enunciadores que estabeleçam relações com outros campos discursivos. Para o caso particular do campo discursivo do catolicismo francês do século XVII, por exemplo, os semas /DEUS/ e /MUNDO/ são utilizados de modo diferente, conforme seja o discurso do jansenismo ou do humanismo devoto. Ao passo que uma relação com o mundo é compatível no discurso do humanismo devoto, isso é incompatível para o jansenismo, fixado na bíblia e não em autores laicos, como os humanistas. Se Deus é a centralidade do discurso jansenista em oposição às demandas seculares, incompatíveis; já, para os humanistas, é plenamente possível a convivência de DEUS com as andanças mundanas dos humanos, como muitas vezes expõe Maingueneau (1995).

Vem a pergunta inevitável: do modo como exposto, isso não significaria uma lei do discurso, uma camisa-de-força, sua mimetização aparente? E como ficaria a questão da transmissão do discurso ao longo do tempo, seus picos e vales, sumiços e ressureições, sua condição de dominância ou não em diferentes conjunturas sóciopolítico-econômicas?

Citando o episódio histórico do Concílio Vaticano II, quando a Igreja Católica muda, de certa forma, seu discurso no mundo, na segunda metade do século XX, o autor diz que para muitos enunciadores, leigos ou pregadores, o "paradigma" anterior foi trocado pelo novo "paradigma", com uma adesão da maioria, o que não significou um enterro de outros discursos presentes no interior dessa instituição, em seus variados grupos, mas um deslocamento relativo de posições enunciativas. Aqui, a própria existência de uma "competência discursiva" serve como um auxiliar de proa para a percepção desses fenômenos mudancistas. O que se pede é que o enunciador discursivo considere seus enunciados como próprios para uma dada formação discursiva, tenham esse discernimento e a habilidade de produzir inúmeros enunciados desde esta matriz. 
No começo do século XXI, 2013, frente às condições de crise econômica mundial do capitalismo, que se arrasta após ser deflagrada em 2008 com a queda do Banco Lehman Brothers nos EUA, o que gerou um contágio forte na Europa e nos principais mercados globalizados e financeirizados, com consequente crise social e desemprego em massa, como na Espanha, a Igreja passa a ter um novo papa, argentino e jesuíta, num quadro de acirramento mundial da disputa por fiéis, cujo nome "Francisco", os gestos "beijar os pés de presidiários" anunciam, em tese, um novo discurso da Igreja Católica, menos voltada para os paços, mais para os passos, como pregava Vieira, o jesuíta brasileiro dos seiscentos, (o imperador da língua portuguesa, para Fernando Pessoa) que pregando aos negros de África, escravizados no Brasil dos canaviais, lhes dizia que seus sofrimentos terrenos eram apenas no corpo, como aqueles de Jesus e seu calvário até a crucificação pelos romanos, mas que suas almas viveriam felizes no céu.

Assim, o discurso da Igreja Católica no Brasil justificaria a escravização dos negros e das negras, naquela conjuntura particular. Os protestantes e católicos foram na mesma direção discursiva no sul dos EUA, que também escravizava homens e mulheres africanos, obviamente com outros ingredientes dessa formação discursiva, ao passo que mercadores do norte dos EUA punham seus navios ao serviço do tráfico internacional de africanos escravizados mundo afora, sem pudores discursivos humanistas algum, mas ávidos pelo vil metal.

Entretanto, isso não esgota a questão da imitação. Ora, o palco é o do interdiscurso, é ele quem dita a dinâmica da cena da enunciação, quem sabe então, por meio do interdiscurso consiga-se andar um pouquinho mais no entendimento dessa relação entre o sistema semântico restritivo da competência discursiva e os enunciados no espaço discursivo? Lógico, o olhar do analista do discurso há que debruçar-se sobre a competência interdiscursiva, entender a "Palavra do Outro" no discurso como um "Simulacro". Ou seja, quando um discurso, no espaço discursivo, se confronta com seu outro, é descabida a imitação, como se fosse falsário de quadros, mas a confrontação, tomando o discurso do outro como simulacros, "que são seu avesso". Não se deve confundir os discursos com as biografias de seus enunciadores, mas perceber nos enunciados a aderência ou não àquela formação discursiva particular.

Outra coisa no palco do interdiscurso: a competência discursiva, essa restrição semântica, esse sistema, passa a ser fundamental para dar pistas sobre a heterogeneidade, 
porque em um sentido, a competência discursiva, longe de excluir o heterogêneo, confere-lhe um lugar privilegiado. Em primeiro lugar, porque ela constitui um sistema interdiscursivo que supõe a presença constante do Outro no centro de cada discurso. Mas também porque, como acabamos de ver, ela nos dá meios de atribuir um estatuto de pleno direito à heterogeneidade: entre os enunciadores que pertencem à mesma formação discursiva, entre os textos de um mesmo enunciador, e mesmo entre diversas partes de um mesmo texto. O fato de dispor desses sistemas de restrições permite justamente ler heterogeneidade lá onde só se percebia um imenso campo em que se embaralhavam em todos os sentidos o mesmo e o outro (MAINGUENEAU, 1995, p. 58).

Se, no espaço discursivo, fica nítida a expressão de discursos polêmicos, extremados, uns versus outros, a competência discursiva, esse sistema de restrições semânticas, pensada como competência interdiscursiva, pode ser lido como um sistema que necessita complementarmente, enquanto modelo teórico, de considerações atenuantes dessas razões. É o caso de perceber "variações coerentes que não se limitam a uma justaposição de diversas competências ou a compromissos que se definem entre elas" em algum grau.

Isso é de extrema relevância para o campo discursivo das relações raciais no Brasil, à medida que, os discursos do mulatismo, do embranquecimento, da negritude, do indianismo e dos povos indígenas, inseridos num mesmo espaço discursivo, carregam uma evidente nota polêmica, como sói a raiz histórica discursiva das relações entre senhores brancos e africanos escravizados no Brasil.

A interdisciplinaridade abre janelas com a literatura e outras semióticas, para a apreensão complexa da semântica do cotidiano, do global dos sentidos. Assevera MAINGUENEAU (1995, p. 63) que “as formações discursivas são acessíveis por outros critérios além dos textuais, em particular por sua incidência histórica".

Ela precisa ser levada em conta na construção do modelo teórico de restrições semânticas para o campo das relações raciais no Brasil, que surge discursivamente no começo do Brasil formalmente como nação independente, segue os oitocentos - seja como realidade ou mito ${ }^{39}$-, avança nos novecentos até o XXI, recorte histórico desta dissertação.

Quanto ao caminhar dos discursos nos tempos sob as alterações climáticas, de temperatura e pressão da história, "estabilidades e instabilidades", pode-se raciocinar

\footnotetext{
${ }^{39}$ É sabido que durante o período colonial e, em grande medida, também ao longo do século XIX, a prostituição era exercida majoritariamente por mulheres escravizadas, africanas ou brasileiras, exploradas por senhores inescrupulosos e confiantes na impunidade. São conhecidas histórias como a de Rosa Maria Egipcíaca, prostituída na região das minas até ser resgatada por um sacerdote. A forçada disponibilidade sexual de negras e mulatas acabou por alicerçar o mito em torno de seu exacerbado erotismo (DUARTE, 2007, p. 30).
} 
em termos de variações nas variações, num fluxo contínuo de novidades discursivas ou, noutra perspectiva, de permanências discursivas, em função de uma formação discursiva originária. Faz-se opção teórica nessa investigação por uma concepção heurística nos quadros de uma permanência discursiva. Longe, no entanto, de uma dogmática discursiva, inamovível pelos tempos afora, importa considerar que fatores como a natureza dos discursos, as instituições e seus perfis, os tipos de discursos, as especificidades conjunturais, compõem um feixe de influências passíveis de serem consideradas nas situações discursivas destacadas. Uma escolha epistemológica impõese nessa investigação: considera-se que,

uma formação discursiva não é um espaço estrutural fechado, já que ela é constitutivamente "invadida" por elementos por elementos provenientes de outros lugares (i.e., de outras formações discursivas) que nela se repetem, fornecendo-lhe suas evidências discursivas fundamentais (por exemplo sob forma de "pré-construídos" e de "discursos transversos)" (PÊCHEUX, 1993, p. 313)

Se a decisão é pelo esforço teórico de construção do núcleo semântico abstrato, do sistema de restrições semânticas, do modelo de competência discursiva ampliada (essa dimensão será explorada mais à frente na investigação) para o campo discursivo das relações raciais no Brasil, de saída, requer apartar-se de certa perspectiva, que chamaremos de microscópica, onde mapeia-se um corpus, seleciona-se os detalhes, acende-se uma vela e usa-se uma lupa para ir retalhando e peneirando lexemas, vocabulários etc., material recolhido e depois levado ao laboratório para análises. Hoje, até aplicativos interpretam textos. Essas análises "metódicas", de recorte micro, tem sua relevância. Porém,

uma coisa é proceder a análises metódicas que desestruturam a complexidade discursiva para isolar esse ou aquele de seus componentes (léxico, argumentação...), outra coisa é pensar globalmente essa complexidade por meio de um sistema simples (MAINGUENEAU, 1995, p. 62).

Ganha corpo a noção de que a formação discursiva "assemelha-se a uma exploração sistemática das possibilidades de um núcleo semântico". Essa tarefa é um desafio nesse capítulo de fundamentação teórica, tendo em vistas o campo discursivo das relações raciais no Brasil e o espaço discursivo derivado, seus discursos: o embranquecimento, o mulatismo, a negritude, o indianismo e os povos indígenas. Partese do pressuposto que esses enunciados são dados por outras disciplinas, o que será visto detidamente adiante.

Pisando nos rastros deixados por Maingueneau (1995), anda-se na direção da construção de um quadro semântico simples para o campo discursivo das relações 
raciais no Brasil, serão cinco polos, que servirão para orientar as trocas discursivas entre eles, o jogo dos enunciados e a ação dos enunciadores. A confrontação discursiva orienta o exercício de montagem do quadro de competência discursiva ampliada, pois a hipótese do primado do interdiscurso requer essa guarida, essa vigília teórica permanente, para que o modelo fique em pé. Percebe-se aqui, não é mister que isso seja comentado, que ao optar por "articulações simples" e por "modelos de sentido", o autor, de certo modo, diminui suas pretensões com vistas a grandes voos teóricos, em troca de pequenos esquemas, mas sólidos o suficiente para dar conta da dimensão do todo, quase que ao modo pascalino,

como já sugerimos, é conveniente ver nesses sistemas não arquiteturas estáticas, mas esquemas de processamento de sentido. Sem cessar, o enunciador se encontra diante de materiais semânticos inéditos; para produzir enunciados conformes à formação discursiva, ele não dispõe de sequências realizadas que deveria imitar, mas de regras que lhe permite filtrar as categorias pertinentes e fazer com que estruturem o conjunto dos planos do discurso. Longe de serem índices de seu "irrealismo", a simplicidade dos modelos de competência seria a condição de sua capacidade de ter imediatamente resposta para tudo no interior de um universo de sentido consistente (MAINGUENEAU, 1995, p. 69).

Esta restrição semântica que se tece ocorre em uma arena cultural bem definida. Não se trata de uma "essência discursiva", uma "profundidade" donde emergirão "superfícies", mas de ordenadores semânticos inscritos na história que tem um papel relevante no espaço discursivo, no melhor entendimento do funcionamento discursivo, dos discursos "individuados" e das pelejas entre eles.

Em função de sua coesão semântica, os mais variados planos discursivos estão submetidos ao sistema, ao modelo, ao quadro da competência discursiva, pois é almejada a apreensão da complexidade de uma semântica global, por isso "não apreende o discurso privilegiando esse ou aquele dentre seus planos, mas integrandoos todos ao mesmo tempo, tanto na ordem do enunciado quanto na enunciação"

Isso gesta um complicador na questão da heterogeneidade constitutiva via interdiscurso, o que requer um pequenino desassossego teórico, a isso MAINGUENEAU (1995, p. 107) se mostrou atento:

de fato, se é uma conquista importante poder pensar o caráter interdiscursivo de enunciados que não apresentam nenhuma marca visível de relação com outro enunciado, não se pode negar que a interpelação do adversário em uma troca regrada, a polêmica, representa um gesto capital, que cria situações irreversíveis, provoca múltiplos encadeamentos de enunciações novas. Para evitar reduzir a especificidade desse nível propriamente polêmico, distinguiremos um nível dialógico, o da interação constitutiva, e um nível polêmico, que como se esclareceu no parágrafo anterior, se responsabiliza pela heterogeneidade "mostrada", a citação, no sentido mais amplo. 
Por outra banda, assim como mostrou Isabela Lustosa, no seu clássico "Insultos Impressos" 40 , onde a autora faz uma leitura de escritos dos primeiros jornais que circularam no Rio de Janeiro entre 1821 e 1823, que aparentam ser uma polêmica por cada um deles ter posição política em contencioso entre si e até abrigam aspectos de, mas que indicam um outro tom: o duelo de capa e espada ou do velho oeste americano, pois via escrita, muitas vezes escondidos em textos assinados com chinfrins pseudônimos, advinha uma epifania de ataques e contra-ataques meramente pessoais ainda que disfarçados, nos pequenos jornais de nomes pomposos e em retórica de palavras difíceis - entre chefes de grupos e facções das elites brancas brasileiras no Rio de Janeiro, em sua azáfama pelo poder no país independente que se instala.

Não obstante, nesse exemplo onde a pretensa polêmica descamba para o achincalhe entre gente graúda de times diferentes munidos de tintas rebuscadas, não deixa de aparecer o debate do liberalismo com escravização de africanos como opção de política de Estado no Brasil.

Nesse livro, em muitas situações ditas polêmicas, não o são, mas sim querelas, que terminam quando morre o impresso ou o apetite do editor que controla o suporte, a citação do oponente é descaracterizada, porque as folhas impressas, o suporte gera um hábito,

nesse caso cria-se uma memória polêmica interna e um público mais ou menos fiel, que assiste a uma espécie de "folhetim" polêmico. As modalidades dessa "folhetinização" estão, é claro, estreitamente ligadas às condições em que os textos são publicados e circulam (MAINGUENEAU, 2010, p. 195).

Seria o popular "disse-que-disse" do mundo oral a imperar no impresso organizado com esse fito. Tempos depois no Brasil, mesmo no rádio, na televisão, na internet, a depender dos editores do suporte, o ritual das querelas se reatualiza.

Isso está presente de forma contundente no caso dos discursos sobre as relações raciais no Brasil, em particular quando é latente a ênfase na querela como dimensão editorial de proa.

No caso da cobertura sobre "as cotas" para o acesso às universidades públicas no Brasil, muitas vezes, a querela apresentada como "polêmica" tinha nítido ar artificioso o pomo da discórdia escolhido a dedo eram duas palavras: "cota racial" - uma armação

\footnotetext{
${ }^{40}$ Proibida no Brasil colonial, a imprensa surge em 1808, assim como a universidade, feito escolas superiores isoladas, praga brasileira. Entre 1821 e 1823, os folhetos impressos, a imprensa nascente é a arena por excelência das disputas de poder, envolvendo, dentre outros, os Andradas e D. Pedro I. (LUSTOSA: 2000).
} 
percebida numa mínima leitura crítica de setores da grande mídia brasileira, nos anos 1990, anos 2000 e nessa década. É o caso da cobertura de setores da grande mídia impressa e televisiva depois da aprovação do PL 73/99 na Comissão de Constituição, Justiça e Cidadania da Câmara dos Deputados, em fevereiro de 2006, onde se quebrou nessa votação um tabu histórico, pois a chamada "igualdade formal", meramente, foi ultrapassada no Brasil em prol de uma igualdade real, um grande salto da democracia brasileira e da cidadania no Brasil.

Ao invés de informar a população brasileira sobre a integridade do PL 73/99 "que trata da reserva de 50\% das vagas nas universidades federais e ensino tecnológico, por turno e por curso, para oriundos da escola pública respeitando-se a proporção de negros e indígenas por região do Brasil, conforme os dados do IBGE", muitos veículos, no geral, setores da grande mídia brasileira, seu editores, elevavam o tom na cobertura jornalística da tramitação do PL 73/99 nas Comissões e no Plenário da Câmara dos Deputados tentando ao mesmo tempo riscar o fósforo e jogar a gasolina na chamada opinião pública nacional por meio da querela: “COTAS RACIAIS!!!”. E dálhe "especialistas" de ocasião para sustentar, como cereja no bolo, com argumentos de autoridade, essa arapuca discursiva. Essa ênfase calava-se sobre o direito, sobre a situação objetiva de exclusão e sobre a cota do privilégio real que vigorava ha muito tempo para o acesso à universidade no Brasil, além de jogar com a estigmatização dos negros, dos indígenas, da escola pública, e ao optar por uma linha de querela com edição vertical, destruir e tornar pretensamente a-histórica a exclusão racial e social no Brasil, portanto, em debate "descabido" automaticamente, ainda que rendesse polpuda audiência. Obviamente, prestava-se a camuflar interesses econômicos e sociais graúdos.

Contudo, na maioria das vezes, diga-se que, há polêmicas sadias, que compartilham "as leis do campo discursivo" e atravessam os tempos históricos. É essa a dimensão que interessa a este estudo, não aquela outra, de caráter folhetinesco que a querela de ocasião abriga.

Justamente a dimensão do inacabado, no quadro da competência discursiva se faz presente, aqui pela via virtuosa que a boa polêmica sadia traz, uma via de cunho complementar ao modelo. Eis a reflexão,

o que se constitui no início da existência de um discurso é uma competência que se encontra investida em um conjunto muito limitado de textos, eventualmente em um só, isto é, em uma cobertura temática muito reduzida. É através do tecido imprevisível que as controvérsias, diretas ou indiretas, vão suscitar progressivamente que essa cobertura vai se tornar uma superfície importante. Certamente, no nível do sistema de restrições, a área de 
incompatibilidade entre os discursos é instituída em seus grandes traços desde o início, mas apenas as interações efetivas atribuirão aos acontecimentos enunciativos seu traçado temático. Os enunciados assim produzidos são, assim, menos a expressão da vontade de desenvolver uma doutrina "completa" e mais um conjunto aparentemente descosido de respostas a falhas cuja emergência é imprevisível e que tecem pouco a pouco uma memória própria do discurso.

Não chegaremos, pois, ao extremo de dizer que a polêmica, longe de somente manifestar a estrutura do espaço discursivo, "contribui para criá-lo", isto é, que o "dialógico", resulta em parte do polêmico. De fato, esses dois níveis só podem emergir juntos. Da mesma maneira que não se pode realmente sair da polêmica sem a intervenção de um terceiro, não se pode propriamente entrar nela: o discurso foi desde sempre tomado por ela, desde que definiu seu espaço de enunciação. $\mathrm{O}$ discurso se encontra assim entre duas memórias convergentes $^{41}$ : uma memória "interna", que vai se enriquecendo e aumentando sua autoridade à medida que o tempo passa, que os textos se acumulam, que os homens desaparecem, tornam-se heróis, ou eventualmente mártires da causa e uma memória de filiação "externa" que o legitima, inscrevendo-o na linhagem dos ancestrais, e dispondo uma linhagem correspondente de adversários (aquela com a qual são chamados a identificarse as figuras do Outro) (MAINGUENEAU, 1995, p. 116).

Já a metáfora tirada da biologia, de uma guerra evolutiva não entre indivíduos, mas entre espécies, que segundo Maingueneau (1995, p. 122), valeria em termos discursivos e levaria a uma substituição discursiva global, a nosso ver, ainda que alimente a interdisciplinaridade, repõe problemas mal digeridos do discurso do "darwinismo social". Entende-se que aqui, o autor desloca a cultura e posiciona mal a biologia, numa espécie de sanha evolutiva.

Para o escopo dessa dissertação, centrada na busca da presença dos discursivos advindos do campo discursivo das relações raciais no Brasil, desde esse espaço discursivo e os respectivos discursos elencados, interessa muito, a imbricação destes discursos com uma instituição ("que não é mero suporte") em particular: o saber, o mundo do ensino, a escola pública, a universidade pública, enfim, o sistema nacional de educação do Brasil. Mais detidamente, as margens dessa institucionalidade.

Nisso avançaremos mais adiante.

Impõe-se agora a questão do que procurar no texto, no corpus, para a efetivação da análise dos discursos em consonância com a fiada teórica em curso. O que é um texto? No que se ater no texto? "A proposição-enunciado é o produto de um ato de enunciação: ela é enunciada por um enunciador inseparável de um coenunciador" Adam (2011, p. 108). No mínimo, no texto, se procura por essa unidade de base, a proposição-enunciado. Avante, pois,

${ }^{41} \mathrm{O}$ duplo trabalho da memória discursiva interior ao campo discursivo é chamado de intertextualidade interna. Um discurso define certa relação com outros campos, segundo sejam citáveis ou não; chamaremos a isto de intertextualidade externa (MAINGUENEAU, 1995, p. 78). 
toda proposição-enunciado compreende três dimensões complementares às quais se acrescenta o fato de que não existe enunciado isolado: mesmo aparecendo isolado, um enunciado elementar liga-se a um ou a vários outros e/ou convoca um ou vários outros em resposta ou como simples continuação. Essa condição de ligação é, em grande parte, determinada pelo que chamaremos orientação argumentativa do enunciado. As três dimensões complementares de toda proposição enunciada são: uma dimensão enunciativa que se encarrega da representação construída verbalmente de um conteúdo referencial e dá-lhe certa potencialidade argumentativa, que lhe confere uma força ou valor ilocucionário mais ou menos identificável. (ADAM, 2011, p. 109).

Essas relações "dentro do texto" são relevantes aqui e se traduzem no esquema construído por Adam (2011, p. 111), como se vê na página seguinte.

Se o objetivo da dissertação é a busca pelo discurso de novos sujeitos sociais, situados à margem no campo educacional brasileiro, por meio das produções textuais, do corpus selecionado, então as reflexões de Adam (2011) indicam categorias analíticas bem precisas para tanto, dado a riqueza do corpus. A escolha recai sobre apenas duas: $a$ responsabilidade argumentativa e a mediação epistêmica ou de percepção.

A responsabilidade argumentativa é o próprio ponto de vista do sujeito, como ele é construído, se se sustenta ou não, se fica em pé ou não, é o polo B da triangulação acima, é quando o sujeito diz o que diz com responsabilidade. Isso está ou não está no texto dos sujeitos, ele se coloca no mundo ou não, se posiciona ou não, em uma dada situação discursiva, pois "o locutor é convidado a realizar por si mesmo o trabalho interpretativo" (ADAM, 2011, p. 113) e "põe-se a questão da validade, mais que da verdade, dos enunciados" (ADAM, 2011, p. 111). Essa responsabilidade argumentativa está no texto ou não está, pois,

no nível enunciativo $\mathrm{B}$, a combinação de uma representação discursiva e de um ponto de vista superpõe-se à alternativa de condição de verdade/ficcionalidade. No nível B põe-se, com efeito, a questão da validade, mais que da verdade dos enunciados: um enunciado é posto como válido conforme o locutor (EU-válido), conforme seu ou seus interlocutores, conforme os outros, para todos ou conforme a opinião comum, a doxa das máximas, provérbios e ditados. $\mathrm{O}$ peso de validade de um enunciado, que liga, portanto A e um ponto de vista $\mathrm{B}$, é um aspecto essencial de seu valor argumentativo e de seu valor ilocucionário C. (ADAM, p. 111). 


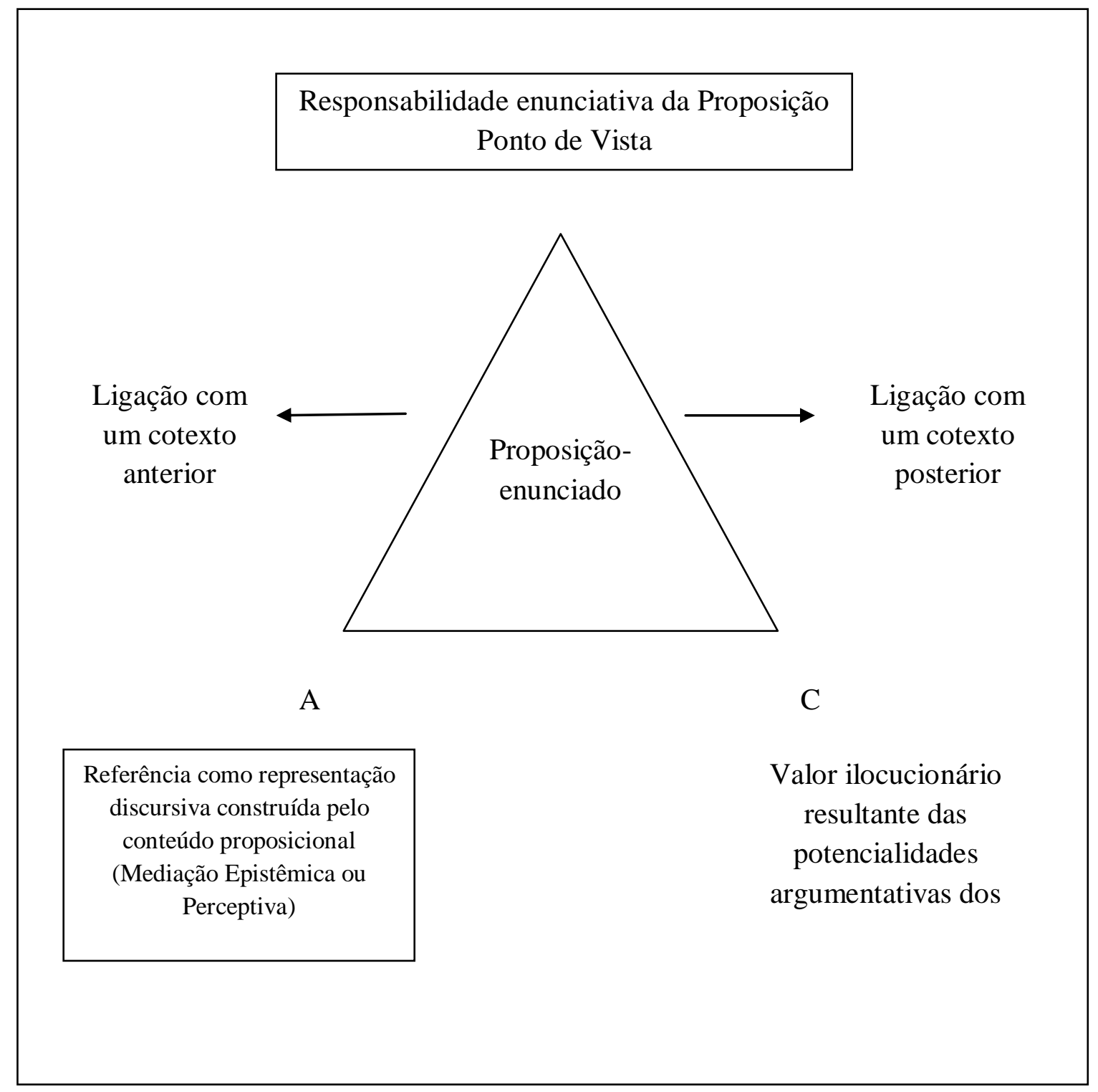

Já a mediação epistêmica ou de percepção é uma forma do que se chama o mediativo, e no corpus, o mediativo, não exclusivamente, mas para a análise aqui adotada, está na sua forma direta na coletânea de textos arbitrados e que são colocados à disposição dos locutores como base comum para a produção textual e na maneira como ela é percebida pelo locutor particular no seu fazer textual, em seu produto, o texto feito.

Assim, os textos tem uma dependência desta "fonte de saber (mediação epistêmica) ou de percepção (mediação perceptiva)" (ADAM, 2011, p. 115) da coletânea, o que pode ir além dela. No esquema de ADAM diz respeito ao polo A.

O mediativo, a mediação epistêmica ou de percepção escolhida e que está na coletânea, estabelece uma conexão direta com os discursos constituintes. Sua extensão é assumida como direta (mais diretamente relacionada com a coletânea fornecida) ou 
indireta (guarda relação com outras mediações). A forma indireta é assumida como relacionada com as disposições culturais e o capital cultural dos sujeitos.

Por fim, fecha-se esta exposição com uma conceituação que tem centralidade para a fundamentação teórica e muita força argumentativa para a investigação em curso: trata-se da noção de competência discursiva ampliada para o sistema de restrição semântica, para o funcionamento discursivo em sua plenitude. Uma vez munidos dessa competência discursiva ampliada, é só ir em frente,

a orientação que damos aqui a nossa reflexão supõe um enriquecimento correlativo da noção de "competência discursiva". Integrando nela inicialmente o estatuto dos enunciadores e seu modo de enunciação, e depois esses fenômenos de vocação enunciativa, definiu-se uma competência que possui uma vertente pragmática, que define também as condições de legitimação do dizer. É um pouco equivalente, no nível do discurso, da "competência ampliada" que Pierre Bourdieu postula, além da estrita gramaticalidade, e que inclui a "capacidade de falar e de agir legitimamente (isto é, de maneira autorizada e com autoridade)... que é socialmente reconhecida a um agente determinado". Cada discurso só existe produzindo sua própria definição das características que devem ser preenchidas "pelo discurso legítimo, os pressupostos tácitos de sua eficácia" (MAINGUENEAU, 1995, p. 131).

O autor argumenta que o discurso não se basta só com o texto escrito no papel. Surge, então, uma noção "remodelada" de discurso, crucial, que não mais se basta em um "domínio exclusivamente textual”, pois carece da apreensão do ambiente discursivo, para que se considere com rigor a "imbricação irredutível entre aspectos textuais e não textuais".

2.5.

Discurso, incorporação, habitus e prática discursiva

É preciso ampliar o mapa conceitual da investigação, tornando-a muito mais robusta para os propósitos que persegue. O corpo, a incorporação de um discurso por um enunciador numa prática discursiva ampliada, a dêixis enunciativa, o lugar social relativo da enunciação, sua legitimidade, donde advém sua força ou fraqueza discursiva, são essenciais para encontrar ou não a emergência do discurso dos Sem Universidade no Brasil, a partir de um corpus estudado à luz dos discursos constituintes das relações raciais no Brasil. Aonde se quer chegar com isso? Além, muito além da tinta sobre o papel em branco, por ora. 
Pontua Maingueneau (1995, p. 93),

trata-se, então, de algo completamente diferente de um dispositivo retórico pelo qual o autor "escolheria" o procedimento mais de acordo como o que ele "quer dizer". Introduziremos a noção de INCORPORAÇÃO para evocar essa imbricação radical do discurso e de seu modo de enunciação.

O sujeito do discurso não é o sujeito do cogito cartesiano, nem um clone de laboratório. Ele fala de onde fala com o corpo que tem. Pode ser negro ou não? Perceber, enxergar o negro ou não, falar sobre isso ou calar. Se a cultura dominante na periferia brasileira informa a força da oralidade e expõe a exclusão social e racial da universidade brasileira em 2003, então a prática da produção de textos precisa de algum modo passar por um confronto aberto com esse domínio, dentre outros confrontos, ser incorporada como prática pelos sujeitos, dentre outras práticas. Há mesmo a decisão de ir para a universidade? Qual o preço a se pagar? Qual é o caminho a seguir? Em que medida isso é meramente abstrato e não está presente nos poros dos sujeitos? Foi incorporado?

Percebe-se aqui a centralidade do corpo para o discurso. O corpo conta. Nele avivam-se as práticas discursivas. Para tanto, um mergulho na história, no pensamento e no discurso da escolástica e na prática da arquitetura gótica na França contribui para o entendimento perseguido nesta investigação, visto que oferece situações que evidenciam a transmutação do discurso escolástico em regulador de um saber prático presente nas construções das catedrais da arquitetura gótica.

Maingueneau (1995) percebe de modo simples e direto a força do operador que surge de Panofsky e é destacado por Bourdieu. O autor de Gênese dos Discursos enxerga convergência entre as abordagens, de modo a sustentar uma competência discursiva ampliada, incorporada nos sujeitos, feito habitus, feito prática social,

o autor de Architeture gothique et pensée scolastique é um especialista em história da arte que, para explicar a estrutura dos edifícios góticos, foi levado a levantar a hipótese de um isomorfismo exato entre ela e o modo de organização da filosofia escolástica, o desenvolvimento das duas séries sendo, aliás, rigorosamente concomitante. A contribuição de Panofsky não foi provavelmente tanto ter descoberto tais afinidades estruturais, o que muitos adeptos do "Zeitgeist" ou da "Weltanschauung" haviam feito antes dele, mas especialmente ter tentado definir o operador que permite estabelecer tal isomorfismo. Para fazer isso, ele escolheu "pôr entre parênteses o conteúdo nocional da doutrina e concentrar a atenção em seu modus operandi", isto é, isolar os esquemas abstratos inconscientes que atuam tanto em um domínio quanto em outro e fundam sua comparabilidade. Ele chama esse "modus operandi" indiferentemente de "hábito mental", de "força formadora de hábitos" ou de "habitus", e lhe atribui um lugar, a escola, pela qual passam os arquitetos, e através de cujo funcionamento se edificou esse modo de pensar escolástico que encontra sua realização suprema nas grandes "sumas" teológicas (MAINGUENEAU, 1995, p.142). 
Sem pôr os pés na contenda entre estruturalistas e pós-estruturalistas ou pósmodernos, o que foge ao escopo dessa investigação, importa destacar três pontos da leitura de Maingueneau: 1) o habitus, como modus operandi, o que tem equivalência com a formulação da competência discursiva ampliada; 2) a "imbricação institucional", a presença da escola; 3) uma relação intersemiótica. Converge o autor,

\begin{abstract}
introduziremos a noção de incorporação (habitus) para evocar essa imbricação radical do discurso e de seu modo de enunciação. Jogando um pouco com a etimologia, faremos aparecer três dimensões essenciais: A) o discurso, através do corpo textual, faz o enunciador encarnar-se, dá-lhe corpo; B) esse fenômeno funda a "incorporação" (habitus) pelo sujeitos de esquemas que definem uma forma concreta, socialmente caracterizável, de habitar o mundo, de entrar em relação com os outros; C) essa dupla "incorporação" assegura, ela própria, a "incorporação imaginária" dos destinatários no corpo dos adeptos do discurso (MAINGUENEAU, 1995, p. 93)
\end{abstract}

Hanks (2008) assinala o equívoco de Bourdieu ao comparar o "habitus a uma gramática gerativa", porém, reconhece a relevância disto para Bourdieu em 1967 (HANKS, 2008, p. 40). Prova de que a empiria, o exercício paciencioso da prática social faz avançar a conceituação em Bourdieu pela estrada da compreensão, como situa a tabela sintética construída por Hanks (abaixo), que, de maneira generosa, explicita novas referências teóricas, novos suportes para o fortalecimento da categoria habitus em Bourdieu. Mauss, Foucault, Aristóteles e Merleau-Ponty entram na conversa do habitus, se assim se pode dizer. "Usos, disposições para agir" regulam as perspectivas individuais. Os agentes se incorporam ao mundo social via "formas de movimento, gesticulação, olhar, orientação no espaço da vida”. Para Hanks,

em termos linguísticos, o habitus está relacionado à definição social do falante, mental e fisicamente, a seus modos rotineiros de falar, à sua gestualidade e ações comunicativas corporificadas, e às perspectivas inculcadas pelas práticas referenciais cotidianas de uma língua (HANKS, 2008, p. 36).

De Aristóteles, Bourdieu conjuga no habitus, a noção de hexis, “disposição individual que combina desejo (intenção) com julgamento (avaliação) presente na compreensão dos outros, do mundo social e no discurso. Vem de MerleauPonty, da conceituação fenomenológica de habitualidade e esquema corporal, " $o$ deslocamento decisivo da noção de disposição para a noção de corporificação" Para Hanks (2008, p. 37),

o esquema corporal de Merleau-Ponty não é nem uma representação do corpo, nem uma mera avaliação de sua dimensão física. Ao contrário, é a prise de consciense (tomada de consciência), o entendimento momentâneo que o sujeito tem de ser um corpo. 
A mobilização, teórica e prática, de que Bourdieu se vale no caso da categoria habitus, encanta pelo caráter interdisciplinar, pela plasticidade da conceituação, o que auxilia a distinguir o habitus como aparece em Panofsky e sua percepção por Bourdieu,

Tabela 2 - Duas definições de habitus (Latim). HANKS, 2008, p. 41

\begin{tabular}{|l|l|}
\hline \multicolumn{1}{|c|}{ Segundo PANOFSKY } & Segundo BORDIEU \\
\hline Hábitos mentais & Habitualidade corporificada \\
\hline Perspectiva avaliativa & Olhar, fitar \\
\hline Desejo/intenção & Inclinação, postura \\
\hline Produção cultural & Trabalho do corpo \\
\hline Esquema mental & Esquema incorporado \\
\hline Execução & Mobilidade \\
\hline Conquistado via treinamento & Conquistado via reprodução \\
\hline Executado em uma prática especializada & Executado na prática ordinária \\
\hline Relativa sincronia (espírito da época) & Diacronia, emergência \\
\hline Desenho de espaço ritualístico & Ocupação do espaço doméstico \\
\hline Relaciona a filosofia à arquitetura & Relaciona o ator social aos campos sociais \\
\hline Crença, ideologia & Apagamento, doxa \\
\hline Regula a ação & Regula a prática \\
\hline
\end{tabular}

Sem mais delongas, essa síntese, além de alimentar a reflexividade na construção da investigação, reforça um indício de convergência conceitual robusta para a categoria habitus em Bordieu, ainda que a questão da reprodução e da sincronia, como abordada por Hanks, dê portas para um espinhoso e necessário debate, no qual infelizmente, não avançaremos aqui.

Importa destacar a "não finitude temporal do habitus", os "espaços cotidianos, como o doméstico", a "disciplina do corpo (mente, incluída)", que emergem como elementos de "uma sociologia prática como apagamento e doxa, isto é como a falsa crença de que a sociedade opera pela razão e pelo mérito (apagamento), e como uma adesão acrítica à sua ordem (doxa)" (HANKS, 2008, p. 43).

Contudo, o habitus só emerge na interação entre os indivíduos e o campo, não tem uma existência isolada, mas relacional, como afirma Bourdieu em seus ensaios 
sobre arte e literatura. E ele serve, como também sintetiza Patrick Champagne, como um "conceito que visa a tirar todas as consequências do fato que o social está inscrito no corpo biológico dos indivíduos" (CHAMPAGNE, 2008, p. 56). O mesmo corpo que é a morada dos discursos.

Isto posto, e, na trilha interdisciplinar, a visada acima anima a investigação a ir de encontro ao real no corpus em seu cotidiano social, pois uma convergência virtuosa de formulações teóricas foi revelada, quebrando amarras disciplinares. O habitus incorporado, esse modus operandi, poderá ajudar muito na compreensão das cenas intersemióticas de enunciação presente no corpus.

Essa jornada por mapas selecionados de fundamentação teórica trilhou árduo caminho e em cada passo acumulou ensinamentos teóricos: de Pêcheux (1982) a necessária valorização do cotidiano; de Authier-Revuz (1982), a importância do sentido em um dialogismo revisitado; de Maingueneau (1995), o interdiscurso inscrito numa competência discursiva ampliada, que dialoga com Bourdieu (1967) e a ideia de habitus, fundamental para o passo analítico perseguido nessa investigação, pois no Brasil, país de universidades tardias e de acesso tardio das massas populares ao direito à educação, peremptoriamente negado pelas elites locais, o problema da escrita sobre as relações raciais é o problema da afirmação e integração de toda a sociedade na nação, atravessada, no horizonte dessa investigação por divórcios clássicos e aparentemente non-senses (que não são), como aquele que distancia práticas de vida e sobrevivência no mundo dos estudos.

Ora, na sociedade brasileira dos oitocentos, o trabalho manual escravizado ficava para o negro, mesmo para os indígenas, ao passo que os estudos, a universidade, aos brancos, onde as exceções confirmavam a regra, caso do negro Rebouças. Essa noção bipartite ganhou o imaginário popular ao longo dos novecentos e adiante: estudar é uma coisa e trabalhar é outra. Por quê? Como? Por uma pressão violenta da reprodução da sociedade brasileira como uma das mais desiguais do planeta. Pelo medo gerado pela necessidade básica de comer, morar, vestir e garantir a reprodução da vida, o sustento da família. Assim, o trabalho coloca-se em oposição aos estudos porque "não dá dinheiro" imediatamente, condição da sobrevivência objetiva nas horas do dia. Com isso, ocorre uma espécie de sequestro do direito de planejar a vida futura a troco de uma brutal pressão curto-prazista para manter-se vivo agora. Não é necessário descartar o quanto interesse as elites brasileiras colocaram na organização da analfabetização das massas no Brasil. 
Fazer convergir abordagens teóricas variadas não é obra de ilusionistas. Se, estabelecer pontes entre autores é um requisito da interdisciplinaridade e, no limite, isso poderia até ferir susceptibilidades acadêmicas mui particularistas, disso não se fez a força motriz da busca teórica aqui enfrentada. Porém, o que reclama por algum grau de interdisciplinaridade é mesmo o desafio real de busca de entendimento dos dilemas da educação nacional para superá-los, um drama social emergencial, particularmente nas camadas populares das grandes periferias urbanas brasileiras.

É desse cotidiano brasileiro da periferia, denso, teórico e real ${ }^{42}$, que pode emergir o discurso dos Sem Universidade, mediado pelos discursos constituintes das relações raciais no Brasil, tomando-se como referência a obra de Maingueneau, mas não só.

\footnotetext{
${ }^{42}$ Michel de Certeau (2011), com bastante autoridade, vislumbrou isso de maneira serena em texto clássico, indicando a convergência entre análises de Maingueneau e de Bourdieu, o que reforça a vitalidade de sentidos nos discursos presentes no cotidiano.
} 


\section{METODOLOGIA}

"As ciências ou disciplinas do texto se cruzam" ou "o texto aparece, assim, como uma unidade construída pela análise" (ADAM, 2011, p.p. 72; 75). Isso traz implicações: "o que faz com que o discurso, ao contrário da frase, seja uma entidade estruturalmente aberta".

Nos textos podem estar os discursos, em particular o discurso dos Sem Universidade. Esse é o centro da metodologia desta investigação, pois nos textos estão as duas categorias analíticas selecionadas como meta da investigação: a mediação epistêmica ou perceptiva (direta e indireta) e a responsabilidade argumentativa dos sujeitos dos discursos.

Para tanto, o estudo identificará uma situação discursiva inicial chamada de discursos constituintes, como o são: 1) o embranquecimento; 2) o mulatismo; 3) a negritude; 4) o indianismo; e, 5) o discurso dos povos indígenas.

A mediação epistêmica e perceptiva ficará a cargo de textos intermediários, inscritos historicamente e tomados como os textos-base para a produção textual dos sujeitos, mas que repercutem o conflito interdiscursivo presente nos discursos constituintes.

A análise ocupa-se dos textos materializados pelos locutores/enunciadores no gênero de discurso chamado avaliação de conhecimento, composto por uma redação e duas questões dissertativas, que consideraremos como documentos históricos, e, complementarmente, por outros registros semiótico-discursivos históricos. Assim, "a enunciação é fundamentalmente tomada no interdiscurso", pois,

a enunciação equivale a colocar fronteiras entre o que é "selecionado" e, pouco a pouco, tornado preciso (através do que se constitui o "universo do discurso") e o que é rejeitado. Desse modo se acha, pois, desenhado num espaço vazio o campo de "tudo a que se opõe o que o sujeito disse" (PÊCHEUX; FUCHS, 1993, p. 193).

Desde essa perspectiva, o objetivo desta dissertação é identificar no corpus a presença do discurso dos Sem Universidade. 
Para tanto, adotar-se-á os seguintes procedimentos de investigação:

1) Identificação e descrição, por intermédio de pesquisa bibliografia, dos discursos chamados constituintes sobre as relações raciais no Brasil, o que informa o espaço discursivo e a efetivação de um exercício de construção de um quadro de restrição semântica global;

2) Descrição do corpus;

3) Desenvolvimento de uma análise das mediações epistêmicas ou perceptivas presentes no corpus à luz dos discursos constituintes e do referido quadro;

4) Análise dos textos selecionados buscando identificar os posicionamentos assumidos pelos sujeitos frente às situações discursivas problematizadas;

5) Verificação da procedência ou não, da hipótese de pesquisa;

6) Desenvolvimento das considerações finais. 


\section{ITINERÁRIOS DISCURSIVOS}

4.1.

O espaço discursivo e os discursos constituintes

Os discursos constituintes, conforme visto na opção teórica central desta investigação, ou seja, em MAINGUENEAU (1995), no geral, conformam um núcleo, um time seleto de autores, uma bibliografia particular, ensejada pela temática da produção textual que é objeto da análise.

São considerados para essa missão, como já sinalizado anteriormente, os seguintes autores: Von Martius (1845), Nabuco (1882), Bilden (1931), Freyre (1933), Junior (1936), Hasenbalg (1997), Henriques (2001), Hofbauer (2006), Carneiro Da Cunha (2012), Nascimento (1968, 1980), Fanon (1960), Fernandes E Bastide (1959), Fernandes (1989, 2007), Celso Furtado (1959), Ramos (1960), Freire (1959), Viotti Da Costa (1998), Dávila (2005), Guimarães (2012), Theodoro (2008). Outros autores podem aparecer incidentalmente.

De modo direto, importa apartar-se no começo de uma viciada polissemia. Para tanto, identifica-se, resumidamente, três sistemas de classificação racial vigentes em parte do mundo hoje: o europeu ocidental, o norte-americano e o brasileiro.

O sistema norte-americano utiliza a regra de hipodescendência, ou seja, descendência traçada a partir do cônjuge inferiorizado socialmente, para traçar os limites dos grupos raciais, que são referidos abertamente como raças. O sistema europeu contemporâneo, desde o fim da Segunda Guerra, rechaça o termo raça e classifica os indivíduos, seja em termos culturais, etnias propriamente ditas, ou a partir da cor da pele, sem referência a descendência biológica. $\mathrm{O}$ sistema brasileiro também recusava o termo raça até recentemente, preferindo o de cor, e também não tem uma regra clara de classificação por descendência, mas utiliza outras marcas corporais, tais como cabelo, formato do nariz e dos lábios para classificar os indivíduos em grupos. Se o termo raça era tabu até a pouco, hoje em dia usa-se correntemente o par "raça/cor" em recenseamentos e pesquisas de opinião (GUIMARÃES, 2012, p. 24). 
Assim, no sistema brasileiro, a "mistura racial é vista como processo histórico". Logo, interessa enxergar o espaço discursivo das relações raciais no Brasil e sua sustentação de modo direto. Através da bibliografia, percebe-se que,

Essa matriz é enunciada pela primeira vez, de modo erudito, no Segundo Império, por Karl Frederick Von Martius, em ensaio de 1845 para o Instituto Histórico e Geográfico Brasileiro. Von Martius chama a atenção para o fato de que a história do Brasil deveria ser escrita levando em consideração que seu povo seria formado pela mistura de três raças - "a cor de cobre ou americana, a branca ou caucasiana, a preta ou etiópica" (Von Martius, [1845] 1956, p.42). Três variantes dessa matriz conheceram desdobramentos para a formação racial negra no Brasil: o embranquecimento, o mulatismo e a negritude (GUIMARÃES, 2012, p. 25).

Se "São essas três vertentes - o embranquecimento, o mulatismo e a negritude que delimitam o espaço ideológico em que vicejam algumas estratégias discursivas negras para a ampliação da cidadania" (GUIMARÃES, 2012, p. 27), quando, a essas vertentes juntam-se o discurso do indianismo e o discurso dos povos indígena, define-se a um só tempo uma referência de espaço discursivo historicamente construído e dos discursos constituintes suficientes para o estudo proposto. Sem exclusividade.

Uma vez convocados a se posicionarem através de texto escrito (fonte dos discursos) frente a uma mediação epistêmica - com lastros nesse espaço discursivo apontado, e, em função da necessidade histórica objetiva da luta pelo direito à universidade no Brasil, ganhará a cena pública brasileira ou não, o discurso dos Sem Universidade, objetivo deste estudo.

\section{2. $\quad O$ discurso do embranquecimento ou branqueamento}

O centro desse discurso era tornar o Brasil um país equivalente a um país europeu, formado por esmagadora maioria branca. A principal ação política nessa direção foi a orientação dada pelo Estado brasileiro para a imigração de brancos europeus para o processo de "substituição" do trabalho escravizado negro e indígena pelo trabalho assalariado no último quartel do século XIX.

Essa receita, contudo, não tocou muitos corações europeus, que preferiram outros destinos para viverem, como os Estados Unidos. As experiências pioneiras, mas nefastas, de imigrantes alemães nas fazendas do Senador Vergueiro em Limeira em 
meados dos oitocentos, viraram denúncia de trabalho escravo na imprensa europeia de então e afastaram muitos alemães do Brasil na época.

No entanto, o embranquecimento como política de Estado foi uma opção do Brasil republicano, uma vez que distintas alternativas estavam disponíveis no xadrez político para a substituição do trabalhador escravizado pelo trabalhador assalariado: milhares de nordestinos que fugiam da seca, os próprios ex-escravizados negros e indígenas.

Para Guimarães (2012, p.p. 25-26),

o embranquecimento da população brasileira surge como um corolário da superioridade da raça branca e da civilização europeia, mas como negação das teorias racistas que teorizavam a mestiçagem como degenerescência. Constitui-se, portanto, no primeiro vértice da matriz enunciado por Von Martius, ao pregar que não apenas o povo conquistador imporia a sua língua e a sua civilização, mas também os seus atributos e qualidades raciais sobres os povos civilizados. Talvez a versão mais bem-acabada dessa versão otimista do embranquecimento esteja na tese apresentada por João Baptista Lacerda (1911) ao Congresso Universal das Raças, em Londres, em 1911. Segundo essa formulação, a raça negra seria absorvida paulatinamente através da miscigenação, gerando um estoque de mulatos eugênicos, assim como, por fim, através de sucessivos intercruzamentos, esses últimos também acabariam por ser incorporados ao grupo branco. É importante notar, entretanto, algumas outras versões da mesma tese: uma mais pessimista - que entendia ser necessária à substituição da raça negra, via intensificação da imigração europeia, expulsão dos africanos libertos e maior mortalidade natural da raça negra - e outra mais otimista - que encarava o embranquecimento como um processo mais geral, que compreendia não apenas miscigenação, mas também a aculturação e assimilação social de negros e indígenas à cultura luso-brasileira. Em suas três variantes, o embranquecimento é uma ideologia de longa duração, e que limita os avanços da cidadania no Brasil.

Uma fatia da ação política no Brasil do discurso do embranquecimento se traduziu efetivamente no embarque de africanos de volta para a África. Tal esforço não teria sido levado até as últimas consequências por conta da falta de fundos públicos para custear a empreitada. Mas ela foi um fato. Manuela Carneiro da Cunha (2012) estudou esse caso por meio das comunidades de descendentes de africanos brasileiros mandados embora do Brasil para a Nigéria. Chico Buarque de Holanda, no livro "Leite Derramado" retrata, na ficção, propositura nesse sentido feita por um Senador do Império: "acabemos com a escravidão, mandemos os africanos todos de volta para a África".

Para Hofbauer (2006), a ideologia do branqueamento vai além de um episódio da mestiçagem em debate na elite brasileira na segunda metade dos oitocentos, pois perpassa toda a história do Brasil e é mobilizada oportunamente e com diferentes estratégias pelas elites políticas, desde os discursos religiosos bíblicos aos discursos 
pseudocientíficos do racismo, às interpretações e assanhamentos sobre os discursos científicos da biologia, seja da seleção natural, seja da genética, conforme a circunstância histórica:

...o ideário de transformar "negro" em "branco" perpassou longos períodos históricos, em que o ideal do branco tem sido (re)semantizado constantemente. Nunca se resumiu à ideia de "transformar uma cor/raça em outra". Na cor branca seriam projetados, ao longo do tempo, além de valores religiosos-morais, outros ideais, tais como liberdade e progresso civilizatório. Esse ideário tem refletido não apenas os anseios e os interesses das elites, mas também tem sido respaldado no imaginário popular. $\mathrm{O}$ ideário do branqueamento postula a supremacia do branco e, ao mesmo tempo, induz os indivíduos a se aproximarem desse ideal. (HOFBAUER, 2006, p. 27).

A birra de setores das elites políticas, de setores majoritários da imprensa nacional, de setores majoritários da academia brasileira, birra transmutada em ferrenha luta política que duraria mais de dez anos no Congresso Nacional do Brasil, tinha como fulcro a propalada cota racial para o acesso à universidade no brasil. Em outros termos, se "branqueasse" a lei, ela seria aprovada. O Comitê Brasileiro pela Aprovação do PLC 180/08, o PL de Cotas, fez essa denúncia, do "neobranqueamento", em manifesto de 2009, quando próceres da coalizão social brasileira contra a aprovação da Lei de Cotas, como o Senador Demóstenes Torres e o publicista da grande mídia brasileira Demétrio Magnoli, dentre outros, apontavam seus dedos irados contra a "racialização" do Brasil, que adviria da "aprovação da Lei de Cotas".

O branqueamento também foi estudado como política educacional presente no sistema de educação da capital federal, o Rio de Janeiro (e não só), nos anos 1917 a 1945, por Jerry Dávila, em "Diploma de Brancura: política social e racial no Brasil 1917-1945", onde se lê,

o que aconteceu com os professores de cor? Eles perderam terreno na maré crescente das ciências sociais, modernização, tecnicização e profissionalização. É interessante constatar que a experiência dos professores de cor sugere que as hierarquias sociais brasileiras se tornaram menos flexíveis à medida que as instituições públicas se tornaram mais racionais e sistemáticas. As instituições públicas e as políticas sociais erigidas nas ondas da construção da nação da Republica e dos anos Vargas normalizaram as hierarquias sociais. As complexas redes de políticas tecnocráticas fixaram lugares e papéis sociais em termos de raça, classe e gênero. Escrevendo códigos sociais em linguagem técnica e científica, educadores e administradores evitaram falar em raça. Sua linguagem psicológica, sociológica e médica forneceu o tom claro da modernidade e da objetividade. O resultado pernicioso dessa fé acrítica na ciência foi o desenvolvimento de um sistema escolar cada vez mais excludente em suas práticas de treinamento e contratação, e cada vez mais discriminatório em seu modo de tratar os alunos. Digna de nota nessas práticas era a ausência de linguagem explicitamente racial contra a qual pudesse se formar uma oposição: a marginalização era encoberta sob um verniz de profissionalismo e tecnicismo (DÁVILA, 2005, p.p. 192-193). 
A presença do branqueamento no "imaginário popular", destacada por Hofbauer (2006) é índice objetivo da relevância desse discurso para os objetivos da investigação.

\section{3.}

\section{O discurso do mulatismo}

O discurso do mulatismo no Brasil transmuta-se em variados nomes, como "mistura", "mesticismo", dentre outros. É nítida uma aposta "metarracial”. O romance "O mulato", de Aluísio de Azevedo, é episódio de inscrição e força deste discurso, dentre variados registros.

O mulatismo guarda relação direta com uma expressão estonteante: "camadas dos livres de cor" (CUNHA, C., 2012), ou seja, alforriados no geral, por "graça" ou dinheiro. Necessariamente a alforria era uma relação privada, de propriedade, uma mostra objetiva do funcionamento do Estado liberal escravizador de africanos e de africanas nos oitocentos no Brasil.

A existência dos alforriados, das alforriadas, que talvez tivessem dinheiro para usarem sapatos, distinção para com a condição descalça dos escravizados no geral e o olhar externo das elites de mando sobre essa massa humana, fornecem a base social para a emergência do mulato, paradoxalmente indicando assimilação e distância ${ }^{43}$ dos brancos no poder na sociedade dos oitocentos, novecentos e alhures hoje ainda.

Ou, numa hipótese nada desprezível, isso acudiria a uma fragmentação de cunho artificioso do tecido social bastante interessante para a manutenção da ordem, à medida que gesta artificialmente diferenciações entre os dominados, facilitando a vida dos dominadores.

Um episódio de relevo desse discurso no Brasil é assim visto,

\footnotetext{
${ }^{43}$ Quando Machado de Assis morreu, um de seus amigos, José Veríssimo, escreveu um artigo em sua homenagem. Numa explosão de admiração pelo homem de origens modestas e ancestrais negros que se tornara um dos maiores romancistas do século, Veríssimo violou uma convenção social e referiu-se a Machado como o mulato Machado de Assis. Joaquim Nabuco, que leu o artigo, rapidamente percebeu o faux-pas e recomendou a supressão da palavra, insistindo que Machado não teria gostado dela. 'Seu artigo no jornal está belíssimo -escreveu a Veríssimo - 'mas esta frase causou-me arrepio: 'Mulato, foi de fato grego da melhor época'. Eu não teria chamado o Machado de mulato e penso que nada the teria doido mais que essa síntese. Rogo-lhe que tire isso quando reduzir o artigo a páginas permanentes. A palavra não é literária e é pejorativa, basta ver-lhe a etimologia. O Machado para mim era um branco e creio que por tal se tomava...' (COSTA, 1998, p. 378).
} 
A manumissão de escravos podia ser feita na época do nascimento da criança, especificamente na pia batismal, por um pagamento nominal, e nesse caso estaria consignado nos registros paroquiais. A pessoa assim liberta era dita "forra a pia", termo que Aluísio de Azevedo ainda usa em O mulato para descrever o status de Raimundo, o herói do romance. Podia ser uma disposição testamentária do senhor, registrada nas provedorias, podia enfim ser conseguida a qualquer momento através de uma carta de alforria, registradas nas notas de um tabelião, carta de alforria esta que podia ser gratuita ou onerosa (P. Malheiro, 1976 [1867], vol. 1: 411-3). (CUNHA, C., 2012, p. 52).

Sem os sujeitos sociais reais, o estrato social real de referência, onde seria a morada do discurso do mulatismo? Numa zona meramente abstrata?

Num país sem universidades nos anos oitocentos, dada a restrição de cursos universitários locais, que eram faculdades isoladas para as elites - e bem poucas (direito, medicina, artes e engenharia), a dimensão interpretativa sobre o social avança em variados registros: jornais, cartas, documentos eclesiais, romances, peças de teatro, escrivães de polícia, na oralidade, via relatos de viajem de cronistas estrangeiros, dentre outros meios.

Para uma fé cega de ocasião sobre o discurso do mulatismo, sem faca amolada crítica alguma, uma alegoria do discurso do mulatismo no social real nacional pode ser encontrada na palavra-chave: "PAPAI LELE SECULORUM", que aparece em Memórias de um Sargento de Milícias, uma crônica de costumes da sociedade brasileira dos oitocentos.

Contudo, foi a organização pelo Estado do Instituto Histórico e Geográfico Brasileiro que indicou um lugar histórico real para reflexões de caráter interpretativo ou teórico sobre a sociedade brasileira, feitas no geral, por intermédio de certames abertos a partir de perguntas formuladas para que a pessoa interessada desenvolvesse por escrito uma tese. As teses selecionadas eram publicadas numa espécie de revista científica do IHGB, com relativa periodicidade. Essa instituição se faz hoje presente no centro do Rio de Janeiro, onde está seu acervo histórico integral.

É dessa instituição (IHGB), espécie de embrião da pesquisa científica na história do Brasil em certas áreas, que aparece a matriz dos discursos sobre as relações raciais no Brasil, numa dimensão de publicação científica, da lavra do famoso e respeitado naturalista alemão nos anos 1840 .

Para Guimarães (2012),

A construção do imaginário de uma nação mestiça, que incluiria a totalidade dos indivíduos livres, foi intensificada pelo movimento abolicionista, e se aprofundou durante o período republicano. Essa formulação talvez se constitua no veio mais refinado do pensamento social brasileiro, que encontra 
seus expoentes, em termos de enunciação, em Joaquim Nabuco e Gilberto Freyre. Segundo esse pensamento, a liberdade conquistada pela abolição da escravidão, transmuta-se imediatamente em cidadania, na ausência de preconceitos de raça. As desigualdades sociais remanescentes passam a se ancorar na ordem econômica e cultural das classes sociais. Cabe ao Estado incorporar e regular através de políticas sociais o acesso dos cidadãos ao pleno gozo de seus direitos, e promover desse modo a justiça, a educação, a saúde e a seguridade de todos. O Estado é o único ente civilizador e promotor da harmonia social. Não há lugar, nesse pensamento, para a teoria de Marshall do desenvolvimento da cidadania pela conquista de direitos. Essa variante da matriz vonmartiana seria chamada por alguns intelectuais de mulatismo, ou seja, de uma forma de conceber a nação brasileira segundo a qual o mulato seria o brasileiro típico, mais que o branco oriundo da emigração europeia ou de sua mistura com os descendentes de portugueses. (GUIMARÃES, 2012, p.p. 26-27).

Desse modo, o mulatismo deslocaria a visão estrita da hierarquia racial e da superioridade racial branca sobre as demais raças, bem como a hostilização da mistura racial como "degenerescência", o que aparece em Euclides da Cunha e na Escola de Antropologia de Nina Rodrigues.

A maior potência discursiva do mulatismo é associada ao livro Casa-Grande \& Senzala, de 1933. A pretensa porosidade cultural brasileira entre as raças dignificaria a própria mistura racial brasileira. Essa noção seria traduzida como "democracia racial" e sobre essa corda bamba discursiva desfilariam, com variadas crenças e interesses, conforme a conjuntura: o Estado-Novo (1937-1945), o Partido Comunista Brasileiro (PCB), o Movimento Negro (anos 1940/1950, atrás de uma “democracia realmente racial”), a Ditadura Militar (1964-1985), dentre outros avisados ou desavisados. Essa corda bamba discursiva, repita-se, vivíssima no real nacional, ora pode travestir-se de utopia a ser perseguida, ora de pacto político sobre o silêncio da condição racial no Brasil ou mesmo reivindicar-se como um mito, à medida que, muitos mitos, tem enraizamento no mundo social e ganham asas e narrativas próprias e para alguns, vida autônoma.

Por outro lado, o mulatismo, quando alçado a uma espécie de alcunha para um tipo-ideal brasileiro, foi realçado, mas como mira incômoda a ser debelada, por parte de parcela de intelectuais paulistas nos anos 1930/1940, pois o quadro geral da política brasileira e da disputa de poder instalado no Brasil nos anos 1930, quando o Estado de São Paulo desafia o poder federal da Revolução de 1930 instalado no Rio de Janeiro, vai indicar várias colisões.

Por exemplo, São Paulo é berço do movimento dos camisas verdes de Plínio Salgado, os integralistas fascistas do sigma grego, de São Paulo; outra vertente são 
intelectuais paulistas do porte de um Monteiro Lobato, mas que somavam forças com os integralista no combate contra uma assombração terrível: a visão do brasileiro como mulato e não como branco europeu, como nortista e não sulista, como relata Guimarães (2012).

Contraditoriamente, porém, no seu "Interpretação do Brasil" 44 , o próprio Freyre sustentará que ao final das contas, o Brasil "será branco". Seria, na época, uma questão de dias contados.

Nessa linha, o discurso do mulatismo, apesar de destacar um tipo-ideal, em tese diferente do branco, não toleraria qualquer outra liderança, a não ser a da cultura europeia cristã branca, sobre o Brasil. Daí que a mescla discursiva pretendida ganhar ares meramente alegóricos e folclóricos - em sua conotação negativa -, algo entre a fantasia presente e futura que nada incomoda o poder de plantão e um passado fantasioso que não indica mexida nenhuma na ordem social vigente, pois mortos não ameaçam vivos assim facilmente.

Esse discurso mereceu crítica de uma leitura da história do Brasil que problematizou a opção pela imigração branca europeia no processo de transição do trabalho escravizado para o trabalho assalariado no Brasil no último quartel do século XIX, feita pela elite política que comandou o implante da República no Brasil, fortemente sob os auspícios do poder dos barões brancos do café paulistas.

Naquela opção de política imigratória houvera o escanteamento dos outros nacionais, dentre eles os do então chamado Norte do Brasil, como indica, por exemplo, Celso Furtado, em Formação Econômica do Brasil.

O que era preconceito, na gênese, de paulista contra nortista no século XIX, transmuta-se em preconceito contra nordestino, no século XX e XXI, no mesmo chão paulista, latência que emerge de setores sociais em variados momentos históricos, como quando uma mulher paraibana foi eleita prefeita de São Paulo, em 1988.

\footnotetext{
${ }^{44}$ FREYRE, Gilberto. Brazil: an Interpretation. New York, 1945. Trad. Bras.: Interpretação do Brasil. Rio de Janeiro, 1947.
} 
De chofre, esse discurso remete a Gonçalves Dias e seus poemas idílicos sobre os índios no Brasil, ao romance Iracema, de José de Alencar e ao dia 19 de abril, cujas memórias discursivas, ornamentais apenas, ainda pipocam em comemorações escolares Brasil afora, de nítida concepção reprodutivista da educação.

O discurso do indianismo, desde meados dos novecentos, opera numa chave de busca de uma origem mítica de conveniência para o Brasil, o que por tabela, garantiria, pelo princípio da hereditariedade, o direito das elites latifundiárias sobre vastíssimos quinhões das terras brasileiras como uma espécie de direito natural a essa propriedade.

Nessa perspectiva, assim como Hobbes no seu Leviatã lança mão do "estado da natureza", do "direito natural", para justificar o poder absoluto dos reis na Europa, mutatis mutandis, no estado da natureza no Brasil existiriam os indígenas, nesse marco se erige uma construção discursiva, um artefato como o discurso do indianismo, que se presta a justificar o poder do latifúndio no Brasil como direito natural, pois, os latifundiários são descendentes de indígenas, pela ótica desse discurso.

Muitos latifundiários incluíram algum cacoete indígena em seus respectivos sobrenomes nos oitocentos, indicando na arqueologia documental brasileira, o sentido desse discurso. Desse jeito, os cartórios Brasil afora não abrigaram apenas a grilagem, mas também um pater familis fictício, como certos ubirajaras. Mito, logro e farsa, simultaneamente?

Nessa leitura, a gênese do discurso do indianismo traz embutida uma métrica do interesse das elites que comandam o território brasileiro: o indígena é o outro útil para alguma coisa do ponto de vista das elites brancas (de fato ou adesão).

Desde este ponto de vista, o indígena é peça, coisa e seu lugar social é dentro do interesse variável externo que comandaria seu corpo, lugar, destino. Nessa lógica, esse discurso se abre às conveniências temporais do poder de plantão. É esse o ensinamento que brota dos estudos seminais de Manuela Carneiro da Cunha.

Assim, nesse discurso, o indígena ora é o trabalho, ora é o insolente, ora é o soldado para a guerra, ora o fujão, ora é o ocupante indesejado de imensas quantidades de terras, ora é o garantidor da vastíssima fronteira externa e da ocupação do interior do Brasil, ora é o que merece ficar, ora é o que precisa ser expulso, ora é o dono da terra, 
ora é o que precisa ser morto para o sequestro efetivo da terra cobiçada, ora é o protetor das riquezas naturais e minerais, ora é o entrave para o progresso e a posse dos milhões de dólares minerais que o subsolo indígena abriga.

Ora é o elemento orgânico de sustentabilidade ambiental permanente, de defesa da natureza, ora é o empecilho para o agronegócio e a expansão da fronteira agrícola.

Ora é o guardião da água de beber, de viver, ora o sabotador do conforto que a energia elétrica possibilita. Aquele que coloca em risco o dinamismo e o crescimento da economia.

O discurso do indianismo aqui não se restringe a uma referência da literatura brasileira, uma dada escola. Mas, o discurso do indianismo, nesse estudo, apresenta-se como o discurso sobre o Outro indígena, homem, mulher, inferiorizado em múltiplas dimensões. Esse discurso é organizado e atualizado por uns, na maioria das vezes, não indígenas, membros das elites, não raro brancos, de fato ou de ficção.

Para o discurso do indianismo o indígena é o assimilável para depois ser o descartável. Ele deve comungar o mundo dos brancos, para depois ser excomungado da sua existência e identidade étnica plural. $\mathrm{O}$ assimilacionismo é uma tradução possível do discurso do indianismo no Brasil.

\title{
4.5. $\quad O$ discurso da negritude
}

Informa Guimarães (2012, p. 27),

\begin{abstract}
Apesar de muito influente no meio negro, e talvez por causa, tal variante não encontrou grande apelo nos meios intelectuais, ficando quase que restrita ao enunciado de Guerreiro Ramos, feito em 1957. A negritude, como bem caracterizou Roger Bastide, consiste numa radicalização do mulatismo, ao enxergar como negros todos os afrodescendentes e propor que, no Brasil, o povo é negro; ou seja, segundo tal enunciado, não faz sentido pensar o negro enquanto etnia separada, posto que ele seja o esteio demográfico da nacionalidade. Por seu turno, a designação do povo como negro, e não mulato ou mestiço, consiste propositadamente na busca de valorizar o elemento mais estigmatizado da formação nacional, revertendo a visão colonialista europeia, introjetada pelas elites nacionais, do Brasil enquanto país branco e de sua cultura como prolongamento da portuguesa.
\end{abstract}

O primeiro africano, a primeira africana, escravizados, já ao pisarem no Brasil, ou, mesmo antes, trouxe consigo a gênese do discurso da negritude. Isso é de grande 
valia, para espantar qualquer assujeitamento perpétuo, para trás ou para a frente, desmemorializador, necessariamente.

Os quilombos revelaram a luta dos africanos escravizados contra a escravização, que pode também ser tomados como referência histórica desse discurso, como é o caso de Palmares, da liderança de Zumbi dos Palmares, onde o protagonismo negro é inquestionável.

A noção de negritude remete diretamente ao posicionamento político de intelectuais da dispersão africana que ganhou grande dimensão mundial no quadro da luta pela descolonização da África e de ex-colônias europeias depois da Segunda Guerra Mundial, donde ressoa o pan-africanismo.

Em si, o pan-africanismo é o interdiscurso de um Outro: aquele dos brancos europeus do Congresso de Berlim, onde a gula da "civilização" quis engolir a África, a Ásia e parte da América Latina. A Conferência de Berlim, a instituição imbricada no discurso da superioridade da civilização branca europeia e o seu pretenso "livre-direito" sobre fatias do mundo, foi proposta por Portugal e teve a participação de Alemanha, Inglaterra, França, Suécia, Espanha, Itália, Bélgica, Holanda, Dinamarca, Estados Unidos, Áustria e Império Otomano, ela foi realizada em novembro de 1884 e fevereiro de 1885: a África seria "dividida" entre os participantes, conforme seus apetites imperialistas em acordo.

O pan-africanismo avança em fins do século XIX como enfrentamento aos desígnios do neocolonialismo da Conferência de Berlim. Intelectuais negros se destacaram nessa luta: William Edward Burghardt Du Bois, historiador e sociólogo estadunidense; Silvester Willians, advogado de Trinidad; Marcus Mosiah Garvey, jamaicano. Em Londres, em 1920 foi realizada a Primeira Conferência Pan-Africana e diversas organizações negras surgiram no mundo da dispersão negra. Éle Semog $(2014)^{45}$, indicia registros do pan-africanismo no Brasil:

Em 1938, o pan-africanismo tem expressão pública no Brasil por meio da realização do Congresso Afro-Campineiro, organizado por Abdias do Nascimento, Aguinaldo Camargo, Geraldo Campos, Agur Sampaio, José Alberto Ferreira e um tipógrafo de nome Jerônimo.

O termo ganha asas no imaginário da luta dos negros, das negras por direitos no Brasil e repercute em produções intelectuais aqui desenvolvidas sobre as relações

\footnotetext{
45 Trecho presente no texto "A antiutopia da república do quilombismo", texto lido pelo autor nas comemorações do centenário de Abdias do Nascimento, em 2014.
} 
raciais: caso de Guerreiro Ramos e Roger Bastide, nos anos 1950/1960, dentre outros.

Teve fortíssima influência no movimento negro brasileiro.

Frantz Fanon, Aimé Cesaire, Senghor Léopold Sendar, Patrice Lumumba,

Toussaint Louverture, dentre muitos outros, são a referência mundial do discurso da negritude, um pan-africanismo pela voz de africanos, da África, de sua dispersão longa, estraçalhada e dolorida mundo afora. Ainda que um tanto longo, cabe o registro sobre um dos principais protagonistas desse discurso:

l'autre grand Antillais de la revolte noire est Frantz Fanon (1925-1961). Il fut l'éleve de Césaire au lycée Schoelcher en Martinique. Il a à peine dix-huit ans quand, abandonnant la classe de philosophie, il quite clandestinement la Martinique, sous gouvernement Du regime de Pétain, pour s'engager dans les Forces françaises libres. Il y découvre son statut non de combatant de la liberté, comme il le croyait naïvement, mais de noir utilisé comme chair à Canon par une puissance coloniale. Cela le déterminera pour le reste de sa vie. Le 12 avril 1945, après le terrible hiver des Ardennes, il écrit à ses parents: "Si jê NE retournais pás, si vous apprenie un jour ma mort face à l'ennemi, consolez-vous mais ne dites jamais: il est mort pour la belle cause. Dites: Dieu l'a rappele à lui: car cette fausse idéologie des instituteurs laïque et des politiciens imbeciles ne doit plus nous illuminer. Je me suis trompé."

Devenu médecin, spécialisé en psychiatrie, alor qu'on lui refuse ses observations cliniques sur "L'image du Noir dans le psychisme européen" comme thèse de doctorat, Il in fait "Peau noire et masques blancs" (1952) où Il psychanalyse l'âme malade des blancs. Ce brillant essai marquait, pouvaiton penser à l'époque, l'enterrement d'um certain discours: aucune personne sensée n'oserait plus parler ouvertement d'âme noire et de race inférieure. Le discours de domination devra user désornmais de camouflages et de détours. Nommé médicin à Blida em 1953, Il recontre sur sa route la lutte des Algériens, aux cotes desquels Il s'engage. Dans Le derniers móis de sa courte vie, il écrit un dernier et brûlant essai politique: Les Dannés de la terre, oraison funèbre d'une certaine "civilisation".

"Quitton cette Europe qui n'en finit pas de parler de l'homme, tout en le massacrant partout où elle le rencontre. [...] L'Europe a pris la direction du monde avec ardeur, cynisme et violence. Et voyez combien l'ombre de ses monuments s'étend et se multiplie. Chaque mouvement de l'Europe a fait craquer les limites de l'espace et celles de la pensée [...]. Elle ne s'est montrée parcimonieuse qu'avec l'homme, mesquine, carnassière qu'avec l'homme." (TOBNER, 2007, p.p. 201-202). ${ }^{4}$

46 Outro grande antilhano da revolta negra é Frantz Fanon (1925-1961). Ele foi aluno de Césaire no Liceu Schoelcher na Martinica. Ele tinha apenas dezoito anos quando, abandonando as aulas de filosofia, deixou clandestinamente a Martinica, sob o governo do regime de Pétain, para se engajar nas Foças Francesas Livres. Ele descobriu não seu status de combatente da liberdade, como ele acreditava ingenuamente, mas de negro usado como escudo humano por uma potência colonial. Isto o marca para o resto de sua vida. Em 12 de abril de 1945, depois do terrível inverno das Ardenas, ele escreveu a seus pais: "Se eu não voltar mais, se um dia vocês souberem de minha morte diante do inimigo, consolem-se mas não digam jamais: ele morreu por uma bela causa. Digam: Deus o chamou para Ele, pois esta falsa ideologia dos instrutores laicos e dos políticos imbecis não deve mais nos iluminar. Eu me enganei."

Tornou-se médico, especializado em psiquiatria, quando recusavam suas observações clínicas sobre " $A$ imagem do negro no psiquismo europeu" como tese de doutorado, ele fez "Pele negra e máscaras brancas" (1952) onde ele analisa psicanaliticamente a alma doentia dos brancos. Este brilhante ensaio marcou, poderíamos pensar à época, o enterro de um certo discurso: nenhuma pessoa sensata ousaria mais falar abertamente da alma negra e de raça inferior. O discurso de dominação deveria usar doravante 
Os deserdados da Terra levantam a cabeça, como sempre o fizeram. "Négritud ou Servitude" escreveriam Towa Marcien e Léopold Sédar Sénghor ${ }^{47}$.

Por excelência, o discurso da negritude nomeia uma tomada de posição objetiva pelo direito do negro, sem peias, sem meias palavras, doa a quem doer. E remete a luta histórica contra a escravização negra, que "destruiu o escravismo por uma luta entre sujeitos historicamente constituídos" (SLENES, 2005, p. 18). Ainda que lhe cortem as cabeças, as hidras reaparecem para lutar por direitos.

A luta pela libertação, independência e autonomia dos povos colonizados de África depois da segunda guerra deu dimensão histórica maior ao pan-africanismo, igualmente a luta contra o apartheid na África do Sul. Kawmw Nkumah, de Gana, Julius Neyrere, da Tanzânia, George Padmore, Patrício Lumumba, Amilcar Cabral, Samora Machel e Agostinho Neto indicam referências da luta pan-africana. A Unidade Africana, foi fundada em 1963 na Etiópia, depois em 2000 foi transformada em União Africana, formada por cerca de 50 países, como ensina o professor Éle Semog em seus variados escritos.

O discurso da negritude aqui adotado, reflete assim, o enraizamento histórico da luta pan-africana negra no mundo, dentre outros possíveis discursos desta enorme luta contra o racismo e a dominação, presentes alhures e mesmo de diversos modos no Brasil..

Nos limites deste estudo, na realidade brasileira, o discurso da negritude é aqui tomado como o discurso que não transige nem tergiversa sobre a condição do negro na sociedade de classes e clama em alto e bom tom pelos devidos direitos de negros, das negras, dos afrodescendentes. O que, comparadas às tintas de Marshall, que descreve a história da cidadania na Inglaterra, equivaleria aos tais direitos civis, políticos e sociais universais, negados e renegados no Brasil aos negros, no rito de reprodução e atualização histórica do racismo brasileiro, que tem cor.

camuflagens e desvios. Nomeado médico em Blida em 1953, ele encontra novamente em seu caminho a luta dos Argelinos, a qual ele se junta. Nos últimos meses de sua curta vida, ele escreveu um último e incendiário ensaio político: "Os condenados da terra", oração fúnebre de uma certa "civilização".

"Deixemos esta Europa que não para de falar do homem, ao mesmo tempo em que o massacra onde quer que ela o encontre [...] a Europa tomou a direção do mundo com ardor, cinismo e violência. E vejam o quanto a sombra de seus movimentos se estende e se multiplica. Cada movimento da Europa rompeu os limites do espaço e aqueles do pensamento [...]. Ela não se mostrou parcimoniosa com o homem, mesquinha, carniceira com o homem.” (TOBNER, 2007, p.p. 201-202) - Tradução livre.

${ }^{47}$ Cf. Yaoundé, CLÉ, 1971. 
A estampa da camiseta "100\% negro", o samba "um abraço negro, um sorriso negro, traz felicidade, negro é a razão da liberdade" ou o escrito de boné "orgulho negro", indicam marcas desse discurso no Brasil.

Por exemplo, o grupo paulistano de Rap "Racionais MC's” reinventam a crônica urbana, onde o direito do negro está no vinil, no $\mathrm{CD}$, na voz. A negritude se encontra no cumprimento, o axé de todo dia. Também no candomblé, na baiana, no jongo, em muito terreiro Brasil afora. Em Carolina de Jesus, Gilberto Gil, Malcon X, Bob Marley, Spike Lee, Mandela. Muitas são outras referências dignas.

Contudo, nesse estudo, o discurso da negritude indica o discurso do próprio movimento negro, da causa negra, em que pese às estratégias discursivas peculiares vistas na longa caminhada da luta por cidadania negra no Brasil, como as estratégias conjunturais do discurso do puritanismo, do modernismo, da democracia autenticamente racial, da igualdade racial.

Isso é uma questão não de achatamento discursivo, da troca de vários discursos por um só, mas de busca de um discurso de referência para a contenda interdiscursiva que se instala nos limites deste estudo, como é latente no caso da luta pelo direito à universidade no Brasil.

A negritude assim, neste estudo, é tomada como o discurso do próprio movimento negro, com a abrangência, atualidade e pluralidade que abriga, como a centralidade dada a questão da igualdade racial, como se viu no processo constituinte dos anos 1980 no Brasil,

na promulgação da Constituição de 1988, disse o Deputado Ulysses Guimarães que o processo que a engendrou teve foro de multidões. No interior dessas multidões, o movimento negro brasileiro foi um dos sujeitos mais ativos. O inciso XLII do art. 5 da Constituição, que tornou o racismo crime inafiançável e imprescritível, foi uma das vitórias alcançadas pelo movimento negro no texto constitucional, e parecia indicar que estávamos no limiar de um novo tempo, de reconciliação da Nação brasileira consigo mesma e com sua história, e a superação efetiva das fábulas de cordialidade racial que mascararam, por tempo demais, as sequelas de um passado escravista e de um presente de exclusão de base racial, em todas as dimensões da vida, que os números das desigualdades raciais sistematicamente veiculadas pelos institutos de pesquisa teimam em demonstrar. A criminalização ao racismo na Constituição mudava radicalmente a visão jurídica sobre esse tema, considerado até aquele momento mera contravenção penal, que o equivalente a cinquenta centavos de multa podia resolver. $\quad \mathrm{O}$ inciso constitucional que tornou $\mathrm{O}$ racismo crime teve sua tipificação complementar na Lei n. 7.716, de 1989, de autoria do ex-Deputado Federal Carlos Alberto Caó, lei que define e pune os crimes resultantes da prática do racismo, indução e incitamento à discriminação racial. Esses dois dispositivos - o dispositivo constitucional e o infraconstitucional - alavancaram as primeiras iniciativas de tratamento da questão racial do ponto de vista jurídico, como o SOS Racismo, assessoria 
jurídica para vítimas de discriminação racial que a minha organização, o GELEDÉS, lançou pioneiramente com o objetivo de, através do caso concreto, sensibilizar o Poder Judiciário para os casos e para a magnitude das práticas de discriminação com vistas à sua punição. No ano passado, a Comissão Interamericana de Direitos Humanos da Organização dos Estados Americanos (OEA), em decisão inédita, condenou o Brasil em um caso de discriminação racial. Então, o que temos? Lutamos pela criminalização do racismo, conquistamos isso na Constituição de 1988, e, na prática social, a impunidade de que se reveste este crime no Brasil permanece cúmplice da violência e dos danos que a discriminação racial provoca. Outra vitória celebrada pelo movimento negro brasileiro, pelo que sinalizava de reconhecimento e de reparação da perversa herança colonial,, foi a que consta nas Disposições Transitórias, art. 68, segundo o qual "aos remanescentes das comunidades de quilombos que estejam ocupando suas terras é reconhecida a propriedade definitiva, devendo o Estado emitir-lhes os títulos respectivos. "No entanto, tal disposição constitucional esbarra na conflituosa situação em que estão imersas as comunidades remanescentes de quilombos, em que as disputas de suas terras ancestrais com empreendimentos agropecuários, madeireiros e grilagem para fins de especulação imobiliária operam para postergar ou negar a titulação de suas terras, direito arduamente conquistado pelos quilombolas. Nos artigos relativos ao tema da cultura, o art. 215 assegura que "o Estado garantirá a todos o pleno exercício dos direitos culturais e acesso às fontes da cultura nacional, e apoiará e incentivará a valorização e a difusão das manifestações culturais." Pode-se considerar que entre os desdobramentos ou regulamentações desse dispositivo constitucional está a Lei n. 10.639, sancionada em 2003, que introduziu o ensino da História da África e da cultura afro-brasileira nos currículos escolares, antiga reivindicação dos movimentos negros brasileiros, e considerado, novamente, um novo marco para o reconhecimento e valorização da participação dos afro-brasileiros na história do País. (CARNEIRO apud CÂMARA, 2009, p. $139 ; 142)$.

E, como convergência discursiva fundamental, pois faz a ponte entre um discurso e uma instituição, como aquelas vistas no breve histórico da luta pan-africana, além da própria Conferência Internacional Contra o Racismo, a Xenofobia e Intolerâncias Correlatas, ocorrida em Durban, África do Sul, em 2001, que indica a força discursiva do discurso da negritude, na acepção tomada nesse estudo, onde a delegação brasileira denunciou a condição do negro, da negra, do afrodescendente no Brasil de modo contundente, o que está em tintas tanto no relatório apresentado pela delegação brasileira, como nos anais daquele importante fórum internacional realizado em terras africanas.

\section{6. $\quad O$ discurso dos povos indígenas}

Não é a fala de um sobre o outro indígena. Nem o discurso feito em nome de. 
Importa aqui deslocar da leitura qualquer iberismo idealizado e enxergar sem rodeios a exploração estrutural do indígena no Brasil desde a instalação do capitalismo e da invasão europeia nos quinhentos.

É dessa condição de povos originários, os "donos" da terra, mas paradoxalmente escravizados - explorados estruturalmente, que faz raízes profundas, é dessa raiz longínqua, de dor, tom forte e acento plural, que brota o discurso dos povos indígenas.

Não é moda de astro de rock mundial, não é a imagem exótica, nem a fala do bom selvagem, nem motivação intelectual interesseira por fáceis laboratórios vivos de humanos para estudos pretensamente isentos e neutros, feito coisas ou objetos para tanto.

É o discurso da causa dos povos indígenas, mais de 180 povos diferentes, cerca de duzentas línguas, culturas, saberes, biodiversidade, espalhados no território brasileiro. Seus direitos têm os próprios índios como seus legítimos porta-vozes.

Assim falou o velho índio tupinambá do Maranhão:

\begin{abstract}
vi a chegada dos peró [portugueses] em Pernambuco e Potiú; e começaram eles como vós, franceses, fazeis agora. De início, os peró não faziam senão traficar sem pretenderem fixar residência [...] Mais tarde, disseram que nos devíamos acostumar a eles e que precisavam construir fortalezas, para se defenderem, e cidades, para morarem conosco [...] Mais tarde afirmaram que nem eles nem os paí [padres] podiam viver sem escravos para os servirem e por eles trabalharem. Mas não satisfeitos com os escravos capturados na guerra, quiseram também os filhos dos nossos e acabaram escravizando toda a nação [...] Assim aconteceu com os franceses. Da primeira vez que viestes aqui, vós o fizeste somente para traficar [...] Nessa época não faláveis em aqui vos fixar; apenas vos contentáveis com visitar-nos uma vez por ano [...] Regressáveis então a vosso país, levando nossos gêneros para trocá-los com aquilo de que carecíamos. Agora já nos falais de vos estabelecerdes aqui, de construirdes fortalezas para defender-nos contra os nossos inimigos. Para isso, trouxestes um Morubixaba e vários Paí. Em verdade, estamos satisfeitos, mas os peró fizeram o mesmo [...] Como estes, vós não queríeis escravos, a princípio; agora os pedis e os quereis como eles no fim [...] (d'Abbeville, trad. Sérgio Milliet, [1614] 1975: 115-6) (CUNHA, C., 2012, p. 19).
\end{abstract}

Até 1848, a França manteria a escravização em suas colônias mundo afora, apesar do discurso da igualdade, da fraternidade e da liberdade, da Revolução Francesa e das cores da bandeira francesa.

Índio fala muito, conversa demais, diria um neófito, de olho no relógio ou no número de linhas. $\mathrm{O}$ visto acima, na verdade, trata-se da simples pulsão viva da cultura oral indígena. Darcy Ribeiro, em suas vivências no meio dos indígenas do centro-oeste brasileiro nos anos 1950 chegava a conversar dias a fio, quase que sem parar. Mais: as conversas avançavam, às vezes, por mais de trezentos anos de história, na ponta da 
língua e da memória dos mais velhos indígenas cheios de sabedoria, que Darcy valorizava e tinha ouvidos de ouvir.

Elisa Frühauf Garcia sustenta que a escravização indígena "começou logo no início da colonização e manteve-se até meados do século XVIII" (GARCIA, 2013, p.p. 27-29). Para Manuela Carneiro da Cunha (2012), mesmo ilegal, isso se arrastou nos oitocentos afora. Nos novecentos também há ocorrências e mesmo nos anos 2000, em muito menor escala, do mesmo trabalho escravizado.

Contra a exploração histórica afirma-se o discurso dos povos indígenas. Um marco desta longa jornada de lutas por direitos foi o processo político da Constituição de 1988 no Brasil, o tom aqui é francamente o da oralidade, onde não vale o susto com o tamanho da citação, aqui quase um breve repertório de importantes conquistas ora em xeque:

[...]Aí fizemos uma articulação, porque todo o nosso povo estava fora e distante. Em 19 de abril de 1982, voltamos para nossa terra de origem. Vivemos dezessete anos nessa fazenda que ocupamos sem ter o direito de aumentar esse espaço. Toda vez que a gente fazia uma ocupação, a gente era expulso dessas áreas pelos pistoleiros dos fazendeiros. A Polícia Militar na época era quem expulsava os índios, ganhando dinheiro dos fazendeiros. Até que surgiu a ideia de criar a comissão de articulação, a nível de sudeste e nordeste, que pegava do Espírito Santo, Minas Gerais até o Ceará. Essa comissão de articulação foi se mobilizando, realizando seus encontros regionais de microrregião, de macrorregião, até a assembleia-geral. E a gente conseguiu ir se organizando e fazendo outras ocupações, não só na área dos pataxós, mas em todo o Nordeste. Em 1988, houve essa mudança no Governo, na Constituição. Viemos para Brasília, trabalhamos a articulação. Foi criada uma comissão organizadora para trabalhar toda essa movimentação, para que o direito do índio fosse assegurado na Constituição. Criamos a CAPOIAB - Conselho de Articulação dos Povos e Organizações Indígenas do Brasil para nos representar em âmbito nacional. Em Brasília, ficamos noventa dias, andando e nos mobilizando. Realizamos uma grande assembleia, fizemos a nossa proposta, colocamos no papel como a gente queria o nosso direito na Constituição. Com o documento final dessa assembleia, andamos de gabinete em gabinete, no Congresso Nacional, nos Anexos I e II, entregando aos Deputados nossa proposta, como queríamos, exigindo deles a assinatura - e a recebemos - e contando com o voto a favor desse direito na Constituição que hoje está aí. Fizemos um trabalho muito pesado. Passamos muitos dias fora de casa, tínhamos de nos acostumar com a cidade, mas a gente sabia que era por um objetivo muito importante para os povos indígenas.

A marcha indígena do ano 2000 veio, a gente articulou na região, fizemos várias ocupações, para, no momento, termos a chance de nos aproximar da imprensa, para divulgar a marcha indígena. E quando a gente consegue realizar a marcha indígena, vem a polícia e dá tiros nos índios, espanca os índios, chuta os índios. E aí a gente fica muito preocupado com essa situação.

A Constituição de 88 deu o prazo de cinco anos para se demarcar e legalizar todas as áreas indígenas. Está com vinte anos e nenhuma foi legalizada. A Raposa Serra do Sol, que foi homologada pelo Presidente da República, está com problema. Foi liberado recurso para o exército desintrusar a área. Aí vem o Judiciário contra o Presidente da República, contra a Constituição e contra o direito constitucional das comunidades 
indígenas e faz um jeito de rever este caso. E até hoje nesta polêmica para se resolver este problema. Quero dizer aos outros companheiros de luta presentes que nós só vamos resolver os nossos problemas na porrada. Vai ser na porrada! Ninguém vai dar nada de mão beijada. Hoje, nós temos 18 mil hectares de terra que recuperamos da mão do fazendeiro, mas foi com a morte do nosso povo. As lideranças tradicionais que começaram a lutar comigo, como o Samado, o Higino, o Desidério, o Eusébio, o Ursulino, o João Cravinho, entre outras, já morreram todas. Foram mortos pelos fazendeiros. Aparece morto lá e, depois, acabou. Ninguém sabe quem foi, nem ninguém descobre quem é. Então, comigo não vai ser diferente. Qual a liderança que morre por aí a não ser assassinada. Então, a gente não tem aquele prazer de ver o fim da luta, de contar a vitória para os nossos filhos, netos e bisnetos. E ainda é preciso derramar o sangue para recuperar as terras roubadas. Nós, índios, depois de concedidos os direitos dos índios na Constituinte, nos mobilizamos novamente, escrevemos uma proposta de um novo Estatuto do Índio. Os índios fizeram a sua proposta, o Núcleo de direitos Indígenas (NDI) fez a proposta dele e o Governo fez a proposta dele. O Conselho Indigenista Missionário tinha também o direito de fazer a sua proposta, mas eles gostaram da que os índios apresentaram e resolveram assessorá-la e apoiá-la. Depois a proposta dos índios não valeu nada para o Governo e ficou sendo discutida a proposta do Governo. Ás vezes a gente discute muito dentro das áreas o seguinte: se a Constituição reconhece a nossa organização social, os nossos costumes, a nossa língua, a nossa crença, a nossa tradição, nós achávamos que eles iriam, baseados nesses direitos, ouvir a nossa voz, respeitar o nosso desejo.

Chega de ouvir os outros dizerem o que é bom para nós. O que queremos é que esse povo respeite o que nós achamos que é bom para nós. Eles não têm de decidir o que é bom para nós. Já é muito importante eles respeitarem o que achamos que é bom para nós. O novo Estatuto está há mais de vinte anos tramitando no Congresso Nacional e até hoje não foi concluído, até hoje não ficou pronto, porque há interesses quanto à revisão constitucional para botarem o que bem entendem (PATAXÓ apud CÂMARA, 2009, 91-123 excertos).

Assim, o discurso dos povos indígenas ocupa espaços e tem presença viva nas redes sociais, na internet, não vê quem não quer. E estudar, ir para a universidade é preciso, também.

\begin{abstract}
"As lideranças perceberam que precisam se capacitar, e cada vez mais elas frequentam cursos universitários", diz o historiador Monteiro. Sônia ratifica: "A gente tem necessidade de estudar para poder contribuir mais com a luta, com meu povo". [...]

Sônia Guajajara tem consciência de que muita gente olha torto quando vê um índio atrás de um computador. Mas ela parece ter ainda mais consciência de suas raízes e de seus objetivos: "Ser indígena não é simplesmente andar pintado, com pena, morando no mato. É também participar da construção das políticas e das tomadas de decisões", ela avisa aos desavisados. (CÂMARA, 2013, p. 40).
\end{abstract}

Uma das instituições de referência para o discurso dos povos indígenas no Brasil e no mundo, dentre outras relevantes, é a Coordenação das Organizações Indígenas da Amazônia (COIAB), que já tem 23 anos: “O que tentamos é ecoar a nossa voz para o mundo, dando visibilidade à nossa riqueza cultural e denunciando a violência e o desrespeito aos nossos direitos", como diz Sônia Guajajara, índia, bacharel em letras, 
pós-graduanda em educação especial e com especialização em gestão ambiental. (IDEM, p. 37).

4.7. Exercício de construção de um quadro de restrição semântica

Adentrando-se diretamente na construção do quadro de restrição semântica da competência discursiva ampliada para o espaço discursivo das relações raciais no Brasil, considerando-se também dimensões sociais, culturais, econômicas e políticas, sem nenhuma pretensão de esgotar esse assunto ou, achatar as infinitas possibilidades de construções superiores a esta, dado que aqui, a opção é por uma lógica simples e suficiente para a compreensão do funcionamento discursivo, consoante os objetivos expostos para a investigação, agora, os passos serão dados linha por linha da tabela abaixo.

Na linha 1, elenca-se onze colunas. A primeira, da esquerda para a direita, é nomeada de "eixos semânticos", cujo objetivo funcional é operar como uma bússola, dando o norte do caminho semântico, em termos de latitude e longitude, ou seja, capaz de sinalizar a semântica global. M1 é o discurso do embranquecimento; M2 é o discurso do mulatismo; M3 é o discurso do indianismo; M4 é o discurso da negritude e M5 dos povos indígenas. Os respectivos sinais nos respectivos discursos indicam as polarizações em torno dos semas arbitrados, de acordo com o primado do interdiscurso e a confrontação, onde o Outro, como simulacro, é constituinte do discurso.

Ainda na linha um, o sema /concentração/ indica a centralização do poder nas mãos da elite branca no Brasil e o sema /contrariedade/ indica a reação a isso por parte dos negros escravizados e dos indígenas. O embrenhamento dos indígenas mato adentro contra os bandeirantes, a fuga dos negros escravizados para os quilombos e a ação política das elites brancas, no sentido de "dividir para comandar" o território e sua reprodução no poder dão as dimensões históricas dessa relação. O advento da "Revolução Francesa dos Negros Escravizados na Ilha de São Domingos", em fins dos setecentos, virou simulacro no discurso das elites brancas brasileiras, na primeira metade dos oitocentos: temia-se o perigo do "haitismo". Uma série de revoltas nos 
oitocentos é reveladora dessa polarização, como as tentativas de independência, as guerras regenciais nos anos 1830. A violência demarcava os campos discursivos. Outro simulacro no discurso das elites foram as leis "feitas para inglês ver", como a de 1831, já referida. A vigência da pena de morte no Brasil, após a Revolução Malês na Bahia em 1835, foi uma reação discursiva à /contrariedade/ dos negros escravizados com sua condição. O indigenismo oficial, de igual moto, levava pânico aos povos indígenas. A lei de terras de 1850, reservou as terras às elites brancas, isolando os negros escravizados e os indígenas da posse do principal bem material num país imenso e de economia rural.

$\mathrm{Na}$ linha dois, o sema /relação/ indica uma quadro de /ordem/ versus /novos arranjos/ ou /inovação/. A ordem vale-se da violência extremada a "leis para inglês ver", para manter em condição inferiorizada, social e racialmente, negros escravizados e indígenas expulsos de terras litorâneas para o interior do país e isolados em direitos. Nos oitocentos o discurso da /ordem/ como a /relação/ fundante da nova nação, ganha a constituição de 1824 e a de 1891 e assume destaque num símbolo pátrio, a bandeira nacional.

Antonio Candido, em o Discurso e a Cidade, indicou originalmente a centralidade da "Ordem", numa lógica de apreensão do "fenômeno geral da ordem e da desordem" presente na sociedade urbana brasileira em sua leitura de Memórias de um Sargento de Milícias, como mote organizador dos discursos que circulavam no Brasil urbano da primeira metade do século XIX,

\footnotetext{
é burla e é sério, porque a sociedade que formiga nas Memórias é sugestiva, não tanto por causa das descrições de festejos ou indicações de usos e lugares; mas porque manifesta num plano mais fundo e eficiente o referido jogo dialético da ordem e da desordem, funcionando como correlativo do que se manifestava na sociedade daquele tempo. Ordem dificilmente imposta e mantida, cercada de todos os lados por uma desordem vivaz, que antepunha vinte mancebias a cada casamento e mil uniões fortuitas a cada mancebia. Sociedade na qual uns poucos livres trabalhavam e os outros flauteavam ao Deus dará, colhendo as sobras do parasitismo, dos expedientes, das munificências, da sorte ou do roubo miúdo. Suprimindo o escravo, Manuel Antônio de Almeida suprimiu quase totalmente o trabalho; suprimindo as classes dirigentes, suprimiu os controles do mando (CANDIDO, 1993, p. 44-45 - grifo nosso).
}

Fora da ordem, o negro escravizado, o indígena quase que somem daquela obra/crônica social, como se não existissem no cotidiano da sociedade dos oitocentos. É a força da ordem, do estigma, do silêncio e da marginalização que os classifica como foras da ordem social, fora do texto. Como sustentáculo estrutural bem visível, inclusive 
na referida obra (afinal trata-se de um Sargento de Milícias) e, quase que perpétuo no Brasil, lá está a violência, contra os outros sociais, sempre para manter a ordem.

Qualquer luta por direitos sociais, como a repartição de terras, o fim da escravização de africanos e indígenas, é repudiada com máxima violência. Os episódios de revoltas no Pará, em Canudos e no Contestado, dão a dimensão da /ordem/, seja no Império, seja na República Velha. Nos anos novecentos, o Brasil passará por duas ditaduras, onde o lema da /ordem/ sustenta a condição de superioridade das elites brancas: o SPI vira FUNAI, e o quesito cor/raça desaparece do censo demográfico de 1970.

$\mathrm{Na}$ linha três, relativa ao sema /número/, divisa-se o sema /homogeneidade/ versus /heterogeneidade/ e /unidade/ versus /pluralidade/, onde de modo inequívoco a homogeneidade remete à sociedade branca de perfil europeu e católica e o castigo se acentua sobre tentativas de pluralidade e heterogeneidade.

$\mathrm{Na}$ linha quatro, o sema ordenador é a /espacialidade/. Nesse caso, impõe-se a /segregação/ versus a/integração/. Negros escravizados, indígenas e pobres são isolados dos espaços das elites brancas. Isso surge artificialmente no solo brasileiro na visão da Casa-Grande e da Senzala (como a metáfora melada das relações sociais no Brasil entre classes sociais diferentes e etnias diferentes), das aldeias indígenas perdidas no mapa, dos escravizados libertos ocupando porões nas cidades, do surgimento das favelas e das grandes periferias até os condomínios fechados, eletrificados e fortemente armados das elites brancas. A educação, salvo exceções, nos oitocentos, era algo proibida aos negros e indígenas, nos novecentos, negros e indígenas quase não conseguem chegar à universidade. Os espaços de saber e cultura, segregados racialmente, são fortemente controlados por elites brancas. "Analfabetos", ou melhor, analfabetizados de caso pensado, depois "analfabetos funcionais" (conceito da UNESCO), ou melhor, funcionalmente analfabetizados, são discursos comuns das elites brancas ao referirem-se aos Outros sociais: negros, indígenas, pobres, nordestinos nos novecentos e mesmo nesses sóis. Que não se iluda, porém: visão que invade, muitas vezes, também o imaginário popular, como pontuava Paulo Freire ao discutir o lugar de luxo do pensamento do opressor na cabeça do oprimido no processo histórico de reprodução da medonha desigualdade social no Brasil.

$\mathrm{Na}$ linha cinco, para o sema /consistência relativa/, as relações raciais na sociedade brasileira mostram-se extremamente hierarquizadas, com o domínio hierárquico da raça branca e escassos espaços de mobilidade social e racial. 
A linha seis, em termos do sema /intensidade relativa/, quase que tem uma chave de leitura nos semas /visibilidade/ versus /invisibilidade/. A visibilidade é branca e a invisibilidade é negra e indígena, a não ser nas situações "exóticas", "folclóricas" ou “decorativas". Por exemplo, mesmo no futebol, foi uma longa luta nos novecentos para que o negro fosse aceito em campo como um jogador igual aos outros. A invisibilidade é cáustica, sutil, dissimulada, muitas vezes. Para um estrangeiro, que via o Brasil lá fora, ele se parecia com um país branco. Desde os relatos dos viajantes até o espanto da Secretária de Estado Condolezza Rice, no XXI, o Brasil é negro, plural e heterogêneo, com os negros em posições sociais inferiores. Quase não há embaixadores negros, professores negros nas universidades de ponta e, o primeiro negro chegou à presidência do STF só em 2012, indicado pelo primeiro Presidente da República trabalhador da história do Brasil. É menos de duas dezenas o número de deputados negros, o número de senadores conta-se nos dedos de uma mão. A representação indígena beira a total invisibilidade parlamentar legal.

$\mathrm{Na}$ linha sete, a /mobilidade relativa/, ocorre um controle vertical da sociedade pelas elites brancas, onde a mobilidade social, a ascensão social, algo que tem mudado muito na primeira década do século XXI, por muito tempo, era restrita a troca de posições dentro das elites brancas. Afora as exceções, a regra era a reprodução do status quo social e racial.

A oitava linha diz respeito ao sema /posição/, no intento de indicar adesão a um epicentro cultural, nominado centro ou sua exclusão cultural, nominada periferia. Com isso percebem-se questões relativas à posição cultural em termos relativos ou mesmo em termos de posse de capital cultural (centro) e sua não posse (periferia). Há contradições evidentes, pois um dos postulados de máximo acento seja no discurso do embranquecimento - com "raça" ou sem "raça" - ou no discurso do mulatismo - onde a "raça" de antigamente vira "cultura" - e, mesmo do mulatismo, diz respeito, na bibliografia, a diferenças “culturais" e não "raciais". É o que se lê,

\footnotetext{
se substituirmos na obra de Nina Rodrigues, os termos biológicos de raça e mestiçamento pelas noções de cultura e aculturação", explica, "as suas concepções adquirirão completa e perfeita atualidade". A concepção de aculturação defendida pelo autor procura superar "determinismos biológicos", mas continua ainda permeada e orientada pela ideia da imposição das "forças civilizatórias". Ramos (IB., P. 53) espera que numa situação de contato entre duas ou mais culturas, a "mais adiantada" tenda a "suplantar a mais atrasada". Assim, o autor acredita que "religiões inferiores" (como, por exemplo, o "fetichismo africano") "aperfeiçoam-se" quando entram em contato com uma forma religiosa mais adiantada" (RAMOS, 1988, p. 144).
} 
A possibilidade de adaptação - "aperfeiçoamento" - das religiões e culturas, descrita por ele, expressa também uma oposição a concepções essencializadas sobre as diferenças humanas. Aqui, o branqueamento já não é mais concebido em termos biológicos. O ideário evolucionista-culturalista propõe, no plano dos "valores culturais", a transformação do outro em "um de nós".

A tensão entre o centro cultural, não raro a Europa e a periferia cultural - a África, ou o que remete a ela; os povos originários - é grande e se faz presente, disfarçada ou não, nos tempos. A catequização forçada, a uniformização forçada dos trajes indígenas, a busca pela cor da alma, são exemplos da contenda entre os capitais culturais. Ou, no limite, uma vez rica, rico, a celebridade - jogador de futebol, artista pode virar "incolor", ocupar o centro cultural.

Ter universidade é ter capital cultural, ser analfabetizado, analfabetizada, não. A universidade tem cor/raça. A analfabetização também. Até na cadeia isso se reproduz no Brasil. Há o centro - para aqueles com curso superior - e a periferia, para os outros.

Já a linha dez aborda o sema /recursos/, que se relaciona basicamente com a questão das classes sociais, aqui estilizadas, grosso modo em ricos, pobres e camadas médias. Percebe-se que, dados discursos atravessam as questões de classe, como pontuou o estudo de HOFBAUER (2006), e também se percebe as alianças ocasionais entre as classes sociais. Muitas vezes na história do Brasil o discurso do mulatismo foi comungado por setores das camadas médias, camadas ricas e até populares, o que informa a potência desse discurso. No limite, uma vez rica, rico, a celebridade - jogador de futebol, artista - pode até virar "incolor".

Por último, o sema /participação/, que informa sobre o tipo de democracia e sob esse prisma, como ocorre a relação entre os discursos. Cabe notar que, mesmo no quadro de democracia ampliada no Brasil, após a Constituição de 1988, percebe-se que a negação do discurso da negritude e dos povos indígenas tem presença no Brasil, talvez porque a democracia ampliada não o seja tanto assim, uma vez que é muito baixa, relativamente, a representação paramentar negra e indígena no Brasil.

Após essa exposição preliminar, as funcionalidades discursivas e suas interincompreensões são percebidas no quadro de restrição semântica da competência discursiva que está exposto, sinteticamente, na página seguinte: 
Tabela 3 - Quadro de restrição semântica da competência discursiva ampliada para o espaço discursivo das relações raciais no Brasil, considerando-se aspectos sociais, culturais, econômicos e políticos (M1 = discurso do embranquecimento; M2 = discurso do mulatismo; M3 = discurso do indianismo; M4 = discurso da negritude; M5 = discurso dos povos indígenas)

\begin{tabular}{|c|c|c|c|c|c|c|c|c|c|c|}
\hline $\begin{array}{c}\text { Eixos } \\
\text { Semânticos }\end{array}$ & $\begin{array}{c}\text { M1+ } \\
\text { Concentração }\end{array}$ & $\begin{array}{c}\text { M1- } \\
\text { Contrariedade } \\
\end{array}$ & $\begin{array}{c}\text { M2+ } \\
\text { Concentração }\end{array}$ & $\begin{array}{c}\text { M2- } \\
\text { Contrariedade }\end{array}$ & $\begin{array}{c}\text { M3+ } \\
\text { Concentração }\end{array}$ & $\begin{array}{c}\text { M3- } \\
\text { Contrariedade }\end{array}$ & $\begin{array}{c}\text { M4+ } \\
\text { Dispersão }\end{array}$ & $\begin{array}{c}\text { M4- } \\
\text { Contrariedade }\end{array}$ & $\begin{array}{c}\text { M5+ } \\
\text { Dispersão }\end{array}$ & $\begin{array}{c}\text { M5- } \\
\text { Contrariedade } \\
\end{array}$ \\
\hline Relação & Ordem & Novos arranjos & Ordem & Novos arranjos & Ordem & Novos arranjos & Inovação & Ordem & Inovação & Ordem \\
\hline Número & Homogeneisdade & Heterogeneidade & Homogeneidade & Heterogeneidade & Homogeneidade & Heterogeneidade & Pluralidade & Unidade & Pluralidade & Unidade \\
\hline Espacialidade & Segregação & Integração & Segregação & Integração & Segregação & Integração & Integração & Segregação & Integração & Segregação \\
\hline $\begin{array}{c}\text { Consistência } \\
\text { relativa }\end{array}$ & Hierarquia racial & $\begin{array}{c}\text { Mobilidade } \\
\text { social e racial }\end{array}$ & Hierarquia racial & $\begin{array}{c}\text { Mobilidade } \\
\text { social e racial }\end{array}$ & Hierarquia racial & $\begin{array}{c}\text { Mobilidade } \\
\text { social e racial }\end{array}$ & $\begin{array}{c}\text { Igualdade } \\
\text { racial }\end{array}$ & $\begin{array}{c}\text { Indiferenciação } \\
\text { racial }\end{array}$ & $\begin{array}{c}\text { Igualdade } \\
\text { racial }\end{array}$ & $\begin{array}{c}\text { Indiferenciação } \\
\text { racial }\end{array}$ \\
\hline $\begin{array}{l}\text { Intensidade } \\
\text { relativa }\end{array}$ & $\begin{array}{l}\text { Escravização, } \\
\text { exploração e } \\
\text { invisibilidade }\end{array}$ & $\begin{array}{l}\text { Equidade, } \\
\text { liberdade e } \\
\text { visibilidade }\end{array}$ & $\begin{array}{c}\text { Escravização, } \\
\text { exploração e } \\
\text { invisibilidade }\end{array}$ & $\begin{array}{c}\text { Equidade, } \\
\text { liberdade e } \\
\text { visibilidade }\end{array}$ & $\begin{array}{c}\text { Escravização, } \\
\text { exploração e } \\
\text { invisibilidade }\end{array}$ & $\begin{array}{c}\text { Equidade, } \\
\text { liberdade e } \\
\text { visibilidade }\end{array}$ & $\begin{array}{l}\text { Equidade, } \\
\text { liberdade e } \\
\text { visibilidade }\end{array}$ & $\begin{array}{c}\text { Status quo, } \\
\text { exploração e } \\
\text { invisibilidade }\end{array}$ & $\begin{array}{l}\text { Equidade, } \\
\text { liberdade e } \\
\text { visibilidade }\end{array}$ & $\begin{array}{c}\text { Status quo, } \\
\text { exploração e } \\
\text { invisibilidade }\end{array}$ \\
\hline $\begin{array}{l}\text { Mobilidade } \\
\text { relativa }\end{array}$ & Verticalidade & Horizontalidade & Verticalidade & Horizontalidade & Verticalidade & Horizontalidade & $\begin{array}{c}\text { Horizontalida } \\
\text { de }\end{array}$ & Verticalidade & $\begin{array}{c}\text { Horizontalidad } \\
\text { e }\end{array}$ & Verticalidade \\
\hline Posição & Centro & Periferia & Centro & $\begin{array}{l}\text { Centro e } \\
\text { Periferia }\end{array}$ & Centro & Periferia & Periferia & Centro & Periferia & Centro \\
\hline Recursos & $\begin{array}{l}\text { Ricos e camadas } \\
\text { médias }\end{array}$ & Pobres & $\begin{array}{l}\text { Ricos e camadas } \\
\text { médias }\end{array}$ & $\begin{array}{c}\text { Pobres e } \\
\text { camadas médias }\end{array}$ & $\begin{array}{l}\text { Ricos, camadas } \\
\text { médias e pobres }\end{array}$ & $\begin{array}{c}\text { Camadas médias } \\
\text { e pobres }\end{array}$ & $\begin{array}{c}\text { Camadas } \\
\text { médias e } \\
\text { pobres }\end{array}$ & $\begin{array}{l}\text { Ricos, camadas } \\
\text { médias e pobres }\end{array}$ & $\begin{array}{c}\text { Camadas } \\
\text { médias e } \\
\text { pobres }\end{array}$ & $\begin{array}{l}\text { Ricos e camadas } \\
\text { médias }\end{array}$ \\
\hline Participação & $\begin{array}{l}\text { Democracia } \\
\text { restringida e } \\
\text { autoritarismo }\end{array}$ & $\begin{array}{l}\text { Democracia } \\
\text { ampliada }\end{array}$ & $\begin{array}{l}\text { Democracia } \\
\text { restringida e } \\
\text { autoritarismo }\end{array}$ & $\begin{array}{l}\text { Democracia } \\
\text { ampliada }\end{array}$ & $\begin{array}{l}\text { Democracia } \\
\text { restringida, } \\
\text { ampliada e } \\
\text { autoritarismo }\end{array}$ & $\begin{array}{c}\text { Democracia } \\
\text { ampliada }\end{array}$ & $\begin{array}{l}\text { Democracia } \\
\text { ampliada }\end{array}$ & $\begin{array}{l}\text { Democracia } \\
\text { ampliada, } \\
\text { democracia } \\
\text { restringida e } \\
\text { autoritasimo }\end{array}$ & $\begin{array}{l}\text { Democracia } \\
\text { ampliada }\end{array}$ & $\begin{array}{c}\text { Democracia } \\
\text { ampliada, } \\
\text { restringida e } \\
\text { autoritarismo }\end{array}$ \\
\hline
\end{tabular}

Elaboração nossa, com base em Mainguenau (1995). 
Como o visto, aparece o espaço discursivo das relações raciais no Brasil, "essa rede de interação semântica" e o processo de "interincomprensão generalizada". Num mesmo gesto, os discursos fundam uma "grade semântica" e o "desentendimento recíproco", o que não descarta situações possíveis de aliança, neutralidade ou outra composição entre os discursos em confronto.

Os discursos do embranquecimento, do mulatismo, do indianismo, da negritude e dos povos indígenas informam polarizações, positivas ou negativas e papéis de agente ou paciente, conforme a posição discursiva respectiva, onde o enunciado de seu Outro, para um dado discurso é traduzido negativamente nas categorias de seu próprio sistema. Assim, no quadro de restrição semântica acima, M1 interpreta como "perigo", e isso é o simulacro do discurso em M4. Ou seja, qualquer inovação institucional, como o fim da escravização dos africanos, sua abolição, seu pleno exercício da igualdade material é encarado como "perigo" em M1, na medida em que isso põe em risco seus privilégios raciais.

Interessa aqui destacar, como mote de precaução, que o espaço discursivo das relações raciais no Brasil, separa-se de uma univocidade e de um antagonismo dual monológico, mas contém variados elementos de complexidade, sem pretensões a monopólios discursivos sagrados.

Por exemplo, o sema /segregação/ que tem uma característica espacial, tem outra primordial, que é a própria cor da pele. Isso alimentou o discurso racista no Brasil, outrora e hoje ainda. No dicionário Houaiss, edição de 1944, revista por Manoel Bandeira, o vocábulo "negro" tinha como sinônimo "escravo".

Foi o fato de uma cientista negra americana, Irene Diggs, insistir em se hospedar no Hotel Serrador em São Paulo em 1947, que "não aceitava gente de cor" ${ }^{48}$, que fez o Brasil ter sua primeira lei na era republicana, que reconheceria o racismo como crime, a lei Afonso Arinos.

No caso do famigerado deputado e da corajosa negra, tanto em sua relação com o quadro de restrições semânticas da competência discursiva ampliada, quanto no confronto interdiscursivo (responsável do hotel versus negra; presidente da comissão de educação versus ativista), é a "semântica do discurso que comanda a maneira como os discursos polemizam". É ingrediente de lucidez perceber que o ensaio minúsculo acima, que indicia uma formação discursiva, dá origem a um espaço discursivo, que tem

\footnotetext{
${ }^{48}$ Abdias do Nascimento aceitou o teste, hospedou-se no H.S. e reuniu um grupo de amigos para desagravar Irene Diggs, conforme foto (ver anexo).
} 
suficiência também, para estabelecer relações e coexistências com outras formações discursivas.

Ao ser uma americana, lugar onde a segregação racial, como nos estados do sul, fazia parte da lei, ou seja, a lei proibia brancos e negros de frequentarem o mesmo espaço, a negra que questionou o hotel brasileiro que, não se ancorava em lei, mas na prática segregava os negros e as negras, possivelmente ocupasse uma posição enunciativa calcada numa outra formação discursiva, que remetesse à história americana. Contudo, se o quadro acima não comporta essa situação, a polêmica instaurada e a contenda, são bem ilustrativos de como, nesse caso, a própria cena discursiva emenda para mais e melhor o soneto das competências semânticas. Essa flexibilidade, o campo discursivo das relações raciais no Brasil enseja, ou seja, uma alimentação semântica advinda da história viva da própria polêmica, pela própria interação viva interdiscursiva.

\section{8. $\quad$ discurso de Uns versus o discurso dos Outros}

Ao destacar os discursos, corre-se o risco de se cair num cipoal discursivo, num emaranhado labiríntico sem saída. Mas, passar com o trator sobre essas realidades discursivas no Brasil é só ver um céu anil e desconsiderar a realidade racial, social, econômica, cultural e sua complexidade histórica interdiscursiva. Para ir além do Bojador discursivo, é preciso ir além da dor também.

Importa então operar clivagens em função do objetivo deste estudo, deixando livre espaço para outras investidas investigativas em aspectos com outros fôlegos.

Os discursos vistos podem ter, simultaneamente, um pé no erudito e outro no popular, isso não é de se espantar no Brasil. As estratégias discursivas acompanham o humor dos tempos, a correlação de forças real na sociedade e viram habitus na classe social, no lugar, no movimento negro, no movimento indígena, no movimento de educação, nos salões e clubes das elites, circulam na sociedade, isso numa perspectiva de luta por direitos historicamente negados.

Assim o puritanismo da Frente Negra Brasileira, o modernismo de vanguarda dos anos 1920/30 de um Mário de Andrade e a questão da alma brasileira, o discurso da democracia autenticamente racial, a negritude, o discurso do igualitarismo racial negro, 
o afro-brasileiro, são estratégias e posicionamentos políticos em diferentes momentos históricos que podem ser lidos como apropriações daqueles discursos constituintes do ponto de vista da inclusão do negro na sociedade de classes, conforme indica Guimarães (2012).

Pela via da luta dos movimentos sociais no Brasil emerge no discurso a importância da singularidade étnica, racial, no combate às desigualdades nos novecentos, no novo milênio.

Assim como ganhou espaço no processo de debate da redemocratização o direito dos povos indígenas, o movimento de redemocratização do Brasil que lutou contra ditadura militar instalada em 1964 avançou na definição da democracia, quando Abdias do Nascimento - e não só ele, como dentre outros clamores do movimento negro: o movimento gaúcho pela celebração de Zumbi dos Palmares, o dia 20 de novembro como dia da Consciência Negra, a criação do Movimento Negro Unificado (MNU) - , em fins dos anos 1970 e começo dos anos 1980, denuncia o genocídio negro. O mesmo Abdias do Nascimento que nos anos 1940/50/60 clamava por uma democracia racial real, pela negritude.

O trabalho educativo de Abdias do Nascimento com a Educação Popular no Teatro Experimental do Negro nos anos 1940/1950 no Rio de Janeiro e de Paulo Freire, na mesma época, no nordeste, ambos num combate cerrado contra a analfabetização, tem convergência como dimensão de práticas educativas reais no meio popular, ação educativa que envolve classe, raça, negros, indígenas, nordestinos, brancos pobres.

Abdias do Nascimento informa uma leitura bem distinta daquela freyreana do masoquista e do sádico (FREYRE: 1933) para explicar a história do Brasil e as relações raciais,

a muralha de preconceito e discriminação que não se vê, mas que existe, é uma criação dos "amigos" do negro. Vedam-lhe na prática, o direito teórico da igualdade. Na verdade ele - o negro - não passa de um cidadão de segunda classe. Seu padrão educacional é realmente baixo. Por isso ele não pode ocupar os postos mais elevados da hierarquia social. Culpa do negro? As crianças negras morrem em maior número: seria culpa de sua inferioridade biológica? Ou de seu baixíssimo padrão alimentar, de saúde, de higiene? O negro não possui especialização profissional para enfrentar o trabalhador de outras origens - terá ele poder de decisões privativas do poder público, para evitar, impedir sua própria degradação? Não pode estudar por falta de meios e não tendo habilitação profissional não pode trabalhar e conseguir os meios de que necessita. É um hermético círculo vicioso da civilização capitalista - e dita cristã - que precisa ser rompida de qualquer forma antes que nós os negros, pereçamos todos. (NASCIMENTO, 1966, p.31). 
Indica, ainda, a força argumentativa do autor, a educação popular presente no

TEN, desde os anos 1940, marco da luta contra a analfabetização imposta aos negros no Brasil por séculos:

A um só tempo o TEN alfabetizava seus primeiros participantes, recrutados entre operários, empregados domésticos, favelados sem profissão definida, modestos funcionários públicos - e oferecia-lhes uma nova atitude, um critério próprio que os habilita a também a ver, enxergar o espaço que ocupava o grupo afro-brasileiro no contexto nacional. Inauguramos a fase prática, oposta ao sentido acadêmico e descritivo dos referidos e equivocados estudos. Não interessava ao TEN aumentar o número de monografias e outros escritos, nem deduzir teorias, mas a transformação qualitativa da interação social entre brancos e negros. Verificamos que nenhuma outra situação jamais precisara tanto quanto a nossa do distanciamento de Bertold Brecht. Uma teia de imposturas, sedimentada pela tradição, se impunha entre o observador e a realidade, deformando-a. Urgia destruí-la. Do contrário não conseguiríamos descomprometer a abordagem da questão, livrá-la dos despistamentos, do paternalismo, dos interesses criados, do dogmatismo, da pieguice, da má-fe, da obtusidade, da boa-fé, dos estereótipos vários. Tocar tudo como se fosse pela primeira vez, eis uma imposição irredutível. Cerca de seiscentas pessoas, entre homens e mulheres, se inscreveram no curso de alfabetização do TEN, a cargo do escritor Ironides Rodrigues, estudante de direito dotado de um conhecimento cultural extraordinário. Outro curso básico, de iniciação à cultura geral, era lecionado por Aguinaldo Camargo, personalidade e intelecto ímpar no meio da comunidade negra (NASCIMENTO, 2004, p. 211).

Por seu turno, Paulo Freire inicia seus trabalhos de educação popular no nordeste, em Pernambuco, nos anos 1940, depois Angicos no Rio Grande do Norte, no Congresso Nacional de Educação de Adultos, no Movimento de Cultura Popular: no centro o combate a analfabetização imposta. Freire (2006, p.p. 133; 139) nos oferece um breve registro disso:

\footnotetext{
"se, o trânsito em que vivemos para uma sociedade "aberta", fatos novos estão dia a dia pondo o homem [e a mulher] brasileiro [/a] em atitudes mais democráticas, não nos esqueçamos que o nosso passado antidialogal, por isso antidemocrático, se afirma constantemente em nossas posições. [...] Não há, na verdade, democracia sem consciência crítica e não há criticidade nas posições massificadoras. Saí a ênfase que teremos de dar à educação para a criticidade. O Centro de Cultura é uma unidade educativa, enfeixando um conjunto de motivos que agregam grupos, que os levam a atividades de objetivos semelhantes".

Sobre os e as alfabetizandos/as (de Angicos - RN), informa-nos o mesmo monitor-educador:

Na pesquisa de Angicos 66 adultos informaram que iam aprender a ler e escrever "para melhorar de vida"; 26 "para ser motorista"; 23 para "ler jornal"; 20 "para ser professor"; outras 20 "para ser boa costureira"; 18 "para ficar sabendo"; 17 "para fazer [escrever] cartas", 15 "para ajudar os outros"; 11 "para ser comerciante", 10 "para votar"; 7 "para dirigir-se"; 4 "para ser músico" e 4 "para ler a Bíblia".
}

Essas são searas, dentro do universo dos movimentos sociais brasileiros, que informam na história do Brasil, referenciados em Abdias do Nascimento e Paulo Freire, 
mas não só eles, o discurso dos Outros sociais que lutam por direitos civis, políticos e sociais valendo-se da educação popular, que tem no microcosmo um macrocosmo. Em jogo o direito pleno à democracia, a entrar no jogo, a ter voz e vez,

onde as condições de que tivessem emergido e se nutrido disposições mentais críticas e por isso mesmo permeavelmente democráticas? Na força das cidades, fundada no poderio de uma burguesia enriquecida no comércio, que substituiu o poder do patriciado rural em decadência?

Não, estas não teriam sido condições que tivessem constituído aquele "clima cultural específico" ao surgimento dos regimes democráticos. A democracia, que antes de ser forma política é forma de vida, que se caracteriza sobretudo por forte dose de transitividade de consciência no comportamento do homem. Transitividade que não nasce nem se desenvolve a não ser dentro de certas condições em que o homem seja lançado ao debate, ao exame de seus problemas e dos problemas comuns. Em que o homem participe. (FREIRE, 1959, p. 76).

O grito sobre o cavalo de Dom Pedro I e o grito sobre o cavalo do Marechal

Deodoro da Fonseca - gestos discursivos muito assemelhados - um para anunciar um Império, outro uma República, tem muito em comum: o povo, como mero detalhe, deixado para pintores incluí-los nos quadros históricos feitos sob encomenda. Retoma Paulo Freire sua reflexão,

entre nós, tem acontecido exatamente o contrário. O alheamento do povo. $\mathrm{O}$ seu quietismo. A sua "assistencialização". De algum tempo para cá, na verdade, sendo substituído por anseios e ímpetos de participação.

O que se pode afirmar é que, de modo geral, ou o povo ficava à margem dos acontecimentos ou a eles era levado, quase sempre, mais como "algazarra" mesmo, do que porque "falasse" ou tivesse voz. O povo assistiu à proclamação da República "bestificado" - foi a afirmação de Aristides Lobo, repetida por todos. Não terá sido realmente apenas a proclamação da República a que ele terá assistido "bestificado". Fernando de Azevedo (1985:30) acrescenta mais recentemente o "golpe de Estado de 10 de novembro de 1937, sem qualquer participação das camadas populares".

Ainda hoje, apesar de todas as condições favoráveis à democratização política e cultural que estamos vivendo, sente-se claramente um gosto às vezes irreprimível pelas soluções verticais, antidemocráticas.

Algumas vezes "cordeiramente" vestido este gosto de eufemismos como "soluções de emergência" ou "esquemas" para salvar a democracia...

Outras vezes apresentado pelo próprio nome, o de formas ditatoriais. (FREIRE, 1959, p. 77)

Não há como errar: ao passo que Uns reinventam o mais do mesmo para a reprodução do status quo, na passagem do bastão de uma educação pela reprodução, de cima para baixo, nas instituições ao talhe das elites, onde as exceções reforçam as regras, Outros fazem o percurso oposto, questionador da ordem, de baixo para cima, necessariamente com os trabalhadores, os pobres, os negros, as negras, os indígenas. 
Aqui aparece um recorte não de ocasião: o discurso de Uns versus o discurso dos Outros. Ou seja, de um lado da história cerram fileira o discurso do indianismo, do mulatismo e do embranquecimento. Noutro time, jogam juntos o discurso da negritude e o discurso dos povos indígenas. Não são polaridades de ocasião. De um lado pode-se dizer que joga o chamado centro cultural, o mundo dito culto, monolinguista, no outro lado, a periferia cultural, o mundo dito não-culto, plurilinguista, morada da língua materna e suas heterogeneidades.

Mas é preciso afunilar ainda mais. Não há escapatória: o discurso dominante e que tem atualidade, do ponto de vista da reprodução do status quo no Brasil, encontra-se numa deriva do mulatismo, no discurso da democracia racial, estilizado, atualizado, ritualizado, o que seja.

Por exemplo, o então todo poderoso Senador Demóstenes Torres, Presidente da Comissão de Constituição e Justiça do Senado Federal, em 2009, jactava-se, por meio de amplos espaços na grande mídia e desde sua posição institucional de poder: "sou mulato", "querem esquecer Gilberto Freyre", "raça não existe", em seus virulentos pronunciamentos contra a aprovação da Lei de Cotas, o PLC 180/08.

Para adentrar no imaginário popular das massas no Brasil, a estratégia do programa partidário de televisão levado ao ar naqueles tempos, sob os auspícios discursivos da liderança do mesmo Senador já tinha nuances: estrelava um negro dizendo que era contra a aprovação da Lei de Cotas para o acesso ao ensino superior federal no Brasil. Confundir, uma das dimensões da arte da guerra e dos discursos.

Já os Outros falam do negro, da negra, dos povos indígenas, dentre outras causas e lutas por direitos civis, políticos e sociais negados. A desigualdade é nomeada no discurso dos Outros.

"Por que Uns e não Outros?" vão para as universidades públicas, pergunta o estudo de Jailson de Souza e Silva (2003, p. 32), sobre a caminhada de jovens pobres para a universidade, a partir do acompanhamento de trajetórias escolares de moradores da periferia do Rio de Janeiro, da Favela da Maré.

Tinha época que a gente discutia em casa, eu e a Márcia, quais foram as influências que nós tivemos nessa coisa de constituir a perspectiva de ir para a universidade, ser determinada naquilo que fazia. A gente avaliava que eram as amizades e a presença de minha mãe, desde o início. Mas o segundo grau não era exigência da minha mãe, a exigência dela era o primeiro grau e a profissão, o segundo grau foi uma determinação nossa, a gente queria continuar estudando. Não queria ser só costureira, como minha mãe pretendia que a gente fosse. Ela achava que a gente ia fazer faculdade e não ia ter emprego, e que o mais importante era ter uma profissão. 
Pela lógica vista, o discurso da democracia racial cai como doce no pote para manter o status quo nas carreiras e cursos das principais universidades brasileiras, quando ferve o debate sobre a Lei de Cotas no Congresso Nacional e na sociedade brasileira.

Por raciocínio complementar, o discurso dos Sem Universidade só pode emergir como discurso dos Outros, dentro da tensão interdiscursiva apontada na fundamentação teórica, dentro da história da educação popular no Brasil, no fio dessa meada, onde o imaginário popular é perturbado pelo discurso dominante da democracia racial e suas artimanhas. 


\section{TRILHAS DISCURSIVAS NOS TERRITÓRIOS}

5.1.

Novíssimos sujeitos sociais fragmentados em territórios da periferia?

Em "Fronteiras de Tensão - política e violência nas periferias de São Paulo", Gabriel Feltran (2011) compara os discursos de outrora, dos trabalhadores brasileiros nos anos 1970 e 1980, como visto em "Quando novos personagens entraram em cena", de Éder Sader (1988), com os novos discursos presentes nas periferias paulistanas nos anos 1990 e 2000, num estudo detalhado de imersão em realidades particulares e mudanças sociais no bairro de Sapopemba e arredores.

Se a obra Miséria do Mundo, de Bourdieu (2011), expressa as mudanças trazidas pelo neoliberalismo na França quase ao tempo das experiências em estudo de educação popular do MSU nas periferias de São Paulo e Grande São Paulo, Fronteiras de Tensão revela a periferia brasileira sem aspas sob o processo histórico da intensa fragmentação - a fragmentação da fragmentação dos discursos dos sujeitos de outrora do novo sindicalismo brasileiro; da luta na clandestinidade e da luta institucional contra a ditadura brasileira; dos Novos Movimentos Sociais (NMS); da ação social da Igreja progressista da Teologia da Libertação - dentre outros fogos cerrados despejados de cambulhada contra a classe trabalhadora, como se aquele sujeito histórico se visse em pedaços, dando adeus aos tipos ideais de trabalhadores e suas respectivas famílias do operariado integrado das grandes fábricas de automóveis dos milhares de peões do modelo fordista de produção, como a noção difusa de pai provedor.

Comecemos por Sader,

Uma comparação com os padrões existentes no período 1945-64 certamente ajudaria bastante na compreensão do problema. Também nesse período a heterogeneidade social provocava a emergência de diversas formas de manifestação social; de operários industriais, de posseiros, de assalariados 
agrícolas, de consumidores contra a carestia, de grupos mobilizados pelo tema do nacionalismo etc. No entanto, a diversidade tendia a inscrever-se em registros unificadores, que ordenavam os diferentes movimentos atribuindolhes lugares diferentes. Eles ganhavam sentido através do discurso estatal, segundo a versão dominante, getulista. Ou então, na contrapartida comunista, através da unificação operada pelo partido.

$\mathrm{Na}$ década de 70 a diversidade se reproduzia enquanto tal apesar da presença de referências comuns cruzando os vários movimentos. Quando acompanhamos a história de vários tipos de organização popular na Grande São Paulo nesse período, nos defrontamos quase sempre com a presença da Igreja Católica, sua rede de agentes pastorais e sua estrutura de funcionamento; com as matrizes discursivas da contestação, mescladas nas práticas concretas onde se encontraram; muitas vezes até com a mesma pessoa circulando de um movimento para outro. A pluralidade de movimentos não está indicando nenhuma compartimentação de supostas classes sociais ou camadas sociais diversas. Está indicando diversas formas de expressão.

Sua história nessa década transcorre fora do reconhecimento estatal. O "novo sindicalismo", do modo como se expressou em São Bernardo, constituiu uma notável exceção no sentido de ter-se desenvolvido no interior da institucionalidade dada. Ainda assim, se o seu lugar institucional era reconhecido como legítimo pelo discurso dominante, o mesmo não se dava com a manifestação autônoma de reivindicação de novos direitos, que por aí buscava se expressar. Os movimentos sociais tiveram de construir suas identidades enquanto sujeitos políticos precisamente porque elas eram ignoradas nos cenários públicos instituídos. Por isto mesmo o tema da autonomia esteve tão presente em seus discursos. E por isso também a diversidade foi afirmada como manifestação de uma identidade singular e não como sinal de uma carência. (SADER, 1988, p.p. 198-199).

Pastorais sociais da Igreja Católica - então progressistas, empurradas pelos ventos do Concílio Vaticano Segundo, de Puebla, México, na segunda metade dos anos 1960; clubes de mães da zona sul, movimento de saúde da zona leste, movimento contra a carestia e o custo de vida, o sindicalismo autêntico do $\mathrm{ABC}^{49}$, oposição metalúrgica em São Paulo, luta política de grupos políticos clandestinos, tudo isso eram córregos sociais fortes, discursos dos Novos Movimentos Sociais (NMS), em grande parte fragmentados, não institucionalizados, sob o peso da ditadura militar no Brasil nos anos 1970, mas que, em sua maioria irão se juntar no grande ascenso das lutas de massas no Brasil nos anos 1980, pela redemocratização do Brasil.

Mesmo em acelerada e multifacetada mudança social, nos anos 1980 os novos sujeitos sociais que entraram em cena em São Paulo e na grande São Paulo, em particular em suas periferias não são fragmentados assim. Por exemplo, há um peso grande para a família no cotidiano e a noção de pai-provedor prevalece numa sociedade

\footnotetext{
${ }^{49} \mathrm{ABC}$ refere-se a um conjunto de sete municípios da grande São Paulo, que por estarem próximos ao Porto de Santos tornou-se forte polo econômico no processo de industrialização do Brasil dos anos 1930 a 1980, com presença intensa das montadoras automobilísticas multinacionais. Além de Santo André, São Bernardo do Campo e São Caetano do Sul, compõem o ABC paulista os municípios de Diadema, Mauá, Ribeirão Pires e Rio Grande da Serra.
} 
de ethos industrial, onde ser peão numa boa fábrica fordista é um sonho de todo trabalhador, de toda trabalhadora,

Nessas decisões podemos observar uma "conciliação" entre os valores dominantes segundo os quais a mulher deve cuidar da casa e as necessidades de aumentar a renda familiar com o seu ingresso no mercado de trabalho. Houve aumento de emprego feminino, mas, considerado "complementar", ele não foi em geral assumido como uma "carreira" e sim como "expediente provisório", contribuindo para sua própria desvalorização.

Pesquisa do DIEESE e do CEDEC realizada a partir de levantamento de campo em 1981 nos fornece ricas informações sobre a diversidade dos "arranjos familiares" efetuados para assegurar o orçamento doméstico, defender-se do pauperismo e possibilitar projetos de melhorias. Nesse trabalho sobre o "Modo e condições de vida na Grande São Paulo", constatamos as relações entre os arranjos familiares e os momentos do ciclo de vida familiar. Aí estão identificados: o "difícil começo" dos casais jovens, em que o trabalho remunerado da mulher tende a ser abandonado com a chegada do primeiro filho, prevalecendo então o padrão de "chefe-provedor" e a mulher cuidando do lar $(25 \%$ das famílias foram consideradas como casais jovens com filhos); o esforço coletivo dos casais adultos com filhos residentes, quando principalmente os filhos começam a ser incorporados no mercado de trabalho ( $30 \%$ das famílias nesse caso); o "esforço coletivo" das famílias com chefe feminino sem cônjuge (13,6\% dos casos); situações mais favoráveis dos casais mais velhos (12\% dos casos) já sem filhos menores e beneficiando-se da combinação de vários recursos (SADER, 1988, p. 105106)

Mudanças no cotidiano perpassam a vida dessas famílias operárias. Não é raro, nas periferias de São Paulo e Grande São Paulo, as famílias bem situadas no mercado de trabalho propiciado pela industrialização, terem alterados padrões de consumo,

o padrão de consumo das famílias operárias parece indicar uma busca de acesso aos padrões de "classe média", difundidos pela publicidade. Essa tendência levou autores a falar de" manipulação das aspirações" e a se perguntarem se tais produtos não permaneciam "estranhos à cultura e padrões de vida da classe operária", "símbolos equivocados de uma ascensão social não conseguida". Penso que a ideia de ter havido manipulação de aspiração, na aquisição de bens que se fizeram símbolos de uma ascensão social frustrada, devem ser levados em conta, mas em si mesmo elas não nos dizem quase nada acerca da cultura e modo de vida dos trabalhadores. Caberia certamente aqui a questão posta por Marilena Chauí acerca da visão romântica sobre a cultura popular que se esquece de indagar "se, sob o discurso

'alienado', submisso à crença nas virtudes de um poder paternalista, não se esconderia algo que ouvidos românticos não são capazes de ouvir".

Ou seja, os "manipulados" também "manipulam". Através da absorção de padrões dominantes eles expressam algo de suas vontades e de seus sonhos e é exatamente isso que é necessário saber ouvir. Como dizer que a televisão é estranha à cultura operária sem com isso negar a realidade vivida e querida pelas famílias de carne e osso? (SADER, 1988, p. 110).

A casa própria e o conforto, como dantes, continuam sendo sonhos de consumo das camadas populares nas grandes periferias de São Paulo. Consumo ou direito? Consumidor ou cidadão? 
Contudo, para que esses movimentos surgissem, e daí emergissem publicamente, não bastavam essas condições objetivas. Muita ação política precisava ser realizada nas bases. E foi. O resultado da ação foi que as camadas trabalhadoras operárias se aliaram, de um lado, a grupos de moradores favelados e cortiços, ainda mais pauperizados, organizados pelas alas progressistas da Igreja Católica. De outro lado, às esquerdas das universidades, das associações e dos sindicatos, que renovaram de modo muito particular as matrizes discursivas da luta popular do período (o catolicismo, o sindicalismo, o marxismo). Daí surgem os novos personagens políticos, os novos movimentos sociais da literatura específica. No plano local, os indivíduos que assumem postos de direção nas associações, nos sindicatos e movimentos populares que pipocavam nas periferias de São Paulo desde o final dos anos 1970 são provenientes de famílias de arranjos semelhantes à de Dona Sílvia (ver o filme Peões, de Eduardo Coutinho). A partir de 1980, essas organizações articularam-se sob o programa do Partido dos Trabalhadores (PT) e aproveitaram da visibilidade de sua aliança com todos esses outros setores sociais para buscar, desde a transição democrática, legitimidade pública para suas demandas. [...

Foram essas dinâmicas que produziram os territórios de Sapopemba até os anos 1980 e que, sem muito alarde, se deslocaram inteiramente a partir da década de 1990. As seguidas crises no mundo do trabalho, centro dessa equação, e o desmantelamento dos aparatos públicos de regulação, que as acompanha, fazem todo esse edifício estremecer (FELTRAN, 2011, p. 100).

Com a crise do industrialismo brasileiro frente aos tsunamis neoliberais dos anos 1980 e 1990, pouco sobrou daquela estrutura nucleada em torno do emprego industrial, cujo peso relativo, em termos de ocupação da força de trabalho, foi rebaixado para a casa dos $20 \%$ na economia brasileira, cujo perfil mudou, onde cerca de $70 \%$ das vagas de trabalho estão concentradas no setor de serviços. O mundo na periferia grande da cidade grande é o mundo dos serviços. É também um mundo penetrado pela violência presente no cotidiano.

Avisa Feltran (2011, p. 97), em atilada etnografia,

Em contextos sociais de franca mudança, é ainda mais difícil: o pai provedor e protetor, a mãe que exclusivamente dirige o ambiente doméstico, os filhos que estudam e conseguem empregos bons tornam-se, com os anos, papéis de tipo ideal, relevantes como referência moral e código de hierarquização interna da família; por isso eles têm relações estreitas com os achados etnográficos, embora não se confundam com ele.

A família nucleada em torno de um chefe-operário perde dominância nas periferias de São Paulo em troco de famílias fragmentadas, com novo papel da mulher, monoparentais, às vezes, mas necessariamente perturbadas pelo ambiente das drogas e da violência desmedida, forte disputa de cabeças no mercado religioso, sem mais a fábrica dos sonhos para se trabalhar ou organizar os passos da ida da vida entre os que vivem, com diminuição dos laços de identidade inter-familiares e intra-bairro, que dirá os laços da classe trabalhadora, como aquela passagem da "classe em si para classe para si”. 
Se a pesquisa entre os ingressantes da USP, em seus oitenta anos de história, indica ano após ano, a irrisória presença relativa dentre os aprovados de códigos de endereçamentos postais das áreas populosas das periferias de São Paulo, a periferia, por outro lado, não é mais a mesma de outrora. A morada dos Sem Universidade mudou. Assinala Feltran (2011),

nenhum tem a estabilidade que os pais tiveram no trabalho e, assim, o trabalho torna-se quase um fim em si mesmo - realização profissional vincula-se à realização pessoal de modo mais direto. Na família operária, ao contrário, o trabalho era mais claramente um meio para o fim, privado, de manutenção e ascensão social da família. Agora individualiza-se mais o projeto: o trabalho se desregulariza e se precariza, mas torna-se ainda mais central para os projetos individuais. As drogas, a violência e o crime apresentam-se para a família, abordam-na, e é na rede de solidariedade familiar que se lida com eles. A família muda, mas segue no centro da representação de segurança individual.

O território dos bairros, das casas de Sapopemba, em que vivem famílias como as de Dona Sílvia, é separado do território das favelas por uma fronteira de distinções entre trabalho, modos de organização da família e expectativa de melhoria. É entretanto, e como se vê, conectado a ela pela presença do crime em ambos os lados, em geral como ameaça, e por vezes como realidade a combater pelas famílias. Das ruínas do sonho operário, regular, traduzido em tantos projetos individuais de ascensão, emerge, portanto, todo um mundo social novo a conhecer. A classe média no horizonte das novas gerações, a periferia na memória existencial.

Se na elite do distrito as histórias podem ser assim, os dois percursos familiares que seguem nos capítulos "De trabalhadores a bandidos" e "Bandidos e trabalhadores: coexistência", mergulham em arranjos entre trabalho, família, religiosidade, projeto de mobilidade e mundo do crime muito distintos. Na mirada comparativa entre eles é que se pode vislumbrar a multiplicidade das fronteiras que delineiam, contemporaneamente, tanto a heterogeneidade interna quanto as marcas da diferença que desenham socialmente aquilo que se conhece, hoje, como a periferia de São Paulo. (FELTRAN, 2011, p. 114-115).

O tratamento dado à periferia de São Paulo por Feltran (2011), suas descobertas em longo estudo etnográfico revela novos discursos nos mesmos ares. E deixa visível o contraste da realidade com aquela de "Quando novos personagens entraram em cena".

É flagrante o decentramento do sujeito, do sujeito da história, em variadas dimensões. O que se relaciona diretamente com a preocupação central dessa investigação.

Mais ainda: com subfrações territoriais dentro do mesmo território disputadíssimo, rua por rua, casa por casa, CEP por CEP - numa espécie de amostra de um novo coronelismo urbano informal de mando e obediência: ao chefe político do lugar, ao chefe do tráfico, aos chefes religiosos das variadas denominações, dentre outros; às alianças e conluios entre eles, numa distritalização sem par da política, submetida à vontade de coronéis urbanos locais superpoderosos, donos dos votos - algo 
que perturba, direta ou indiretamente a refinada etnografia do autor. E indica o perfil da democracia brasileira na base da sociedade.

Meio que sutis, um tanto expostos, esses discursos variados no lugar, que são índices do poder local, sem serem todos os discursos do lugar, estão incrustados nas estruturas sociais mais moles que duras - se é que é mole o metal da bala contra corpos de adolescentes negros, se é que é duro o sonho de um (a) adolescente da periferia em ir para a universidade quando ela (e) não consegue retê-lo dentre os dedos das mãos como um direito- numa hierarquização informal dos espaços, morada de variadas digitais do poder, coesionadas ou tensionadas por nuvens reais de violência e poder político concentrado/partilhado tacitamente ou escancaradamente: o padre, o pastor, a ONG, o político, o time, a quadra, a escola, a festa, a favela, os moradores de antigamente, os novos moradores, os novos estilos de vida sobre as heranças dos jeitos anteriores de viver a vida, o crime organizado, a polícia, o comércio, a vida certa, a vida errada, a droga, o dinheiro, o recuo histórico da grande mobilização popular meio mítica de antigamente (da causa a que todos unem, acorrem, como se a política formal num gesto só, que pactua e se beneficia do jogo das cartas marcadas no território, colando o poder disponível e a violência, engolisse duma só vez a vitalidade da política real necessária à cidadania plena), aparece os novos heróis, as novas heroínas populares sem quixotismo nem glamour - mas sem o reconhecimento generoso da história, às vezes, gente marcada para morrer. Nuvens duradouras ou passageiras sobre a periferia da cidade e seus discursos. Valdênia, a grande líder popular que emergiu em anos de luta do CEDECA Sapopemba, não foi mandada para o céu precocemente, como tantos outros jovens, mas salvou a vida graças à proteção da lei nacional de proteção dos direitos humanos, foi para a Europa. O discurso dos direitos sociais dá de cara com o duro discurso da ordem maioral no território dominado, que mata e manda matar.

O trabalho precarizado, o trabalho terceirizado, o desemprego como pimenta nos olhos (às vezes aparece mais, às vezes desaparece), a violência dentro de casa e na rua, o que faz com que muitas famílias, não raro, acomodem agentes do mundo formal do trabalho dentre os seus membros, ao mesmo tempo em que também acomodam, sob o mesmo teto, agentes do crime organizado.

Nada de comer a comida quente e queimar a língua: não se trata do "pósestruturalismo" ou da "condição pós-moderna".

O CEDECA Sapopemba, base empírica do estudo etnográfico de cerca de dez anos de Feltran (2011), é fruto objetivo do veio daqueles córregos discursivos por 
direitos sociais que brotaram das matrizes discursivas presentes nos Novos Movimentos Sociais (NMS) nos anos 1970/1980, como estudado no clássico “Quando novos personagens entraram em cena". Da luta coletiva por uma política nacional para crianças e adolescentes nos anos 1970/1980 nasceu a regulamentação do ECA, o Estatuto da Criança e do Adolescente, e da lei, o parto dos CEDECA's Brasil afora.

Se esse córrego discursivo chamado luta pelo direito da criança e do adolescente foi canalizado, espezinhado, espremido nos anos neoliberais dos 1990, não é por isso que despreza-se suas fontes históricos, como por exemplo, a matriz discursiva da Igreja em favor dos pobres, o discurso e a prática da Teologia da Libertação na América Latina, que tem intersecções e heranças históricas nessa ação social em Sapopemba, pela presença da instituição Igreja ou de agentes progressistas desta instituição.

Dessa generosa fonte discursiva no Brasil, também brota o nome MSU, cunhado por Dom Pedro Casaldáliga, símbolo da luta dos excluídos no Brasil nos anos 1970/1980.

É por isso que o interesse nesses autores que buscam entender os discursos dos sujeitos e suas mudanças nas periferias de São Paulo, em momentos históricos diferentes, tem enorme peso conceitual e interpretativo, extremamente importante para a exploração dos territórios da periferia paulista.

Feltran (2011) fala da periferia de São Paulo, lócus de onde aparecem os documentos do corpus dessa investigação. O estudo referido é da parte para o todo, do estudo detido do CEDECA Sapopemba até a luta na rua, no parlamento, no executivo, no judiciário pela garantia de direitos sociais para crianças e adolescentes, muitos deles em conflito com a lei.

Já Miséria do Mundo é uma obra densa, uma espécie de imersão no tudo ao mesmo tempo agora, um mosaico peculiar da sociedade francesa no começo dos anos 1990, um painel de vários casos isolados que informam sobre o todo social e o que se chamava antigamente de visível esgarçamento do tecido social francês.

Como aparece a noção de habitus nesses universos? No caso brasileiro, a chegada de pessoas oriundas das chamadas classes C, D, E na universidade recentemente indica mudança social pela via da educação? Como aparecem os discursos das relações raciais nesses autores?

Em Fronteiras da Tensão, de Gabriel Feltran, a periferia paulistana se apresenta como uma espécie de paralelo, mais com muito mais desigualdade social e racial do que em Miséria do Mundo? 
Por que não é o mesmo neoliberalismo na França e no Brasil? Os sujeitos históricos mudaram, em quais dimensões? Os discursos e as práticas sociais indicam novos agentes na cena social? Como aparece o direito á universidade nas periferias brasileiras? Eles são enunciados ou não por novíssimos sujeitos sociais como um direito autonomamente clamado, individual e coletivamente reclamado na arena pública, no espaço público?

A reflexão sobre o volume "A Miséria do Mundo", conjunto de entrevistas realizadas por Pierre Bourdieu e equipe, com cerca de mil páginas na edição original francesa, num projeto de pesquisa financiado por um banco francês que queria um estudo sobre a pobreza e que revela as formas brutas do sofrimento humano percebido na França, particularmente em seus arrabaldes e as tramas sociais que o perpassam, como na revolta dos jovens imigrantes dos "banlieurs", no começo dos anos 1990, anos de apogeu novo-liberal no mundo, no geral, da França em particular.

Tempo histórico em que o Estado de Bem-Estar Social, erigido a duras penas na Europa no pós Segunda Guerra Mundial, como o caso francês, é colocado em xeque pela onda de financeirização do mundo. No Brasil, ao que se sabe, nenhum rastro daquele Estado de Bem-Estar Social francês ou europeu vigorou na segunda metade do século XX e nos primórdios do XXI.

Um dos maiores méritos de BOURDIEU (2011) nessa grande azáfama urbana de muitas vozes, é identificar o embate pela vida dos seres humanos comuns e seus cotidianos. Em termos de apreensão do todo social, não custa relativizar: das periferias e suas inserções nas cidades, já alargava os horizontes do Brasil as crônicas de João do Rio e Lima Barreto, do começo do século XX no Brasil, bem como Capão do Pecado, de Ferrez e Cidade de Deus, de Paulo Lins, nos primórdios do XXI, mas esses escritos não ganharam status de ciência, em sentido estrito, por conta da dimensão ficcional. $O$ mesmo não se poderia dizer de "Desigualdades raciais e segregação urbana em antigas capitais", de Garcia (2009) e "Favela, alegria e dor na cidade", de Souza-e-Silva e Barbosa (2005).

No estudo de Bourdieu (2011) há a garantia plena da fala, dos discursos dos sujeitos fragmentados pela lida da sobrevivência, um esmerado fazer cioso de a todo tempo explicar e refletir sobre o que se faz, o que alimenta uma compreensão perspicaz. Ao fazer isto, Bourdieu (2011) se dá conta de um enorme fenômeno social: como vivem os imigrantes na França. 
No capítulo "Efeitos de lugar" (BORDIEU, 2011, p.p. 159-214), o cotidiano da periferia dos conjuntos habitacionais dos imigrantes na França, local de revolta massiva de jovens, no geral, filhos de imigrantes, é atravessado por imagens de televisão de revoltas em bairros negros e hispânicos nos Estados Unidos da América do Norte, como se Califórnia, Chicago e o arrabalde francês fossem um só nó cego.

O mosaico ímpar e mutante vivenciado pelos franceses no geral, pelas pessoas comuns do lugar dos acontecimentos, pelos interesses potencializados da cobertura midiática, da grande política e da pequena política, ganha cor singular no enredo enunciado pelos homens e mulheres comuns, que com diversos olhares, enxergam, vivem, sofrem e narram suas histórias. Nesses efeitos de lugar o habitus emerge. O problema que se destaca é como romper com as falsas evidências e com os erros inscritos no pensamento substancialista dos lugares, que lhe fixa estigmas, como no caso dos guetos americanos, marcas que ganham asas pela mídia? Assombrações.

Para Bordieu, coloca-se a discussão da necessidade de uma análise rigorosa das relações entre as estruturas do espaço social e as estruturas do espaço físico.

Para facilitar esse olhar, ele vale-se de uma figuração. Ao invés da metáfora estrutural dura - que no limite remete ao concreto armado dos prédios -, o autor ponta para uma estrutura flexível, das artes: os móbiles de Calder.

Assim, sem um determinismo duro, os lugares, como o Móbile de Calder, são carregados de relações e essas relações deixam seus sinais nos corpos dos indivíduos biológicos, nas coisas, em suas respectivas localizações precisas, no lugar em si, em sua posição relativa a outros lugares e coisas, na graduação disso, na ordem, no espaço, nos bens e serviços presentes e ausentes, na estrutura visível e invisível, num agente particular, na hierarquia entre os agentes e nas distâncias sociais, no longe e no perto.

Se, como indicou a leitura crítica de Feltran (2011) o trabalho para o indivíduo tem centralidade em sua vida, se, ademais, esse trabalho é precarizado, pois há uma dominância desse tipo de relação de trabalho dentre os indivíduos na periferia no novo milênio, isso pode levar a uma condição de alienação, à medida que o trabalho precarizado indica um horizonte grande de pressão sobre os indivíduos no cotidiano em termos de curto prazo, da impossibilidade de planejamento, pela pressão diária pela sobrevivência, dado que o que ele possui de capital, centralmente, é sua força de trabalho, no geral,

Esse é o risco central da reificação do lugar, onde qualquer processo de natureza dinâmica e criativa passa a apresentar determinadas características de um objeto 
inorgânico, petrificado, com fixidez e automatismo mecânico. O abstrato vira algo material ou concreto. A incorporação insensível das estruturas da ordem social realizase, sem dúvida, para uma parte importante das pessoas, através da experiência prolongada e indefinidamente repetida das distâncias espaciais nas quais se afirmam distâncias sociais e também, de modo concreto, através dos deslocamentos do corpo, que essas estruturas sociais, convertidas em estruturas espaciais, na relação entre o centro e a periferia da cidade grande, que assim, naturalizadas, organizam e qualificam socialmente como ascensão ou declínio, entrada ou saída, a aproximação ou o distanciamento em relação a um lugar central valorizado. É arriscado dizer, mas é como se o mundo fosse dado e pronto acabou. Ali e do jeito que é, é o mundo, e só. O mundo acaba ali, é o que se vê, é assim. Por que ir para a universidade pública? Estudar noutra cidade? Há uma descrença generalizada nas possibilidades e nas potencialidades abatidas por um peso enorme do real.

Não há panaceias na cena social. O espaço social encontra-se inscrito, impregnado, ao mesmo tempo nas estruturas sociais e nas estruturas mentais, no subjetivo e no objetivo. O espaço social é um dos lugares onde o poder se afirma e se exerce, na sua forma sutil, por meio da violência simbólica, seus discursos e os seus efeitos reais. Aí ocorrem as disputas pelo espaço, as lutas por poder. Os que não possuem capital são mantidos à distância, tanto física, como simbolicamente. À boa e relativa distância dos bens socialmente mais raros, tanto fisicamente como simbolicamente e, condenados a estar ao lado das pessoas ou dos bens mais indesejáveis e menos raros.

Para Bourdieu (2011), a falta de capital intensifica a experiência de finitude. Ela prende o indivíduo a um lugar. O desassossego pessoal e familiar gerado pela precarização do trabalho é enorme, Gabriel Feltran deixa pistas disso no seu escrito. Os autores convergem, nesse ponto, para o que um dito popular repete sem cessar no Brasil: "vender o almoço para comprar a janta", ou seja, a vida levada adiante sob a terrível perspectiva de curto prazo, uma ditadura do curto-prazismo, aprisionada mais ainda pela noção de sucesso que inunda o ambiente social, oriunda dos grandes discursos da propaganda e seus objetos eleitos para o desejo de consumo das massas.

O habitus contribui para construir o habitat através dos costumes sociais mais ou menos adequados que enseja, estimula, como o capital social de relações e ligações sociais, proporcionando algum capital social pelo efeito de clube, tão importante como os outros capitais (econômico, cultural), pois pode render, pode ser multiplicado. 
No lugar, o reconhecimento social, pode gerar também um capital simbólico, como o caso de um líder religioso. É impossível de se prever, no lugar, como se combina o capital econômico, o capital social, o capital cultural, o capital simbólico. Cada capital pode se fragmentar e se multiplicar, ou seja, uma gama variada e variados ângulos caracterizam as posições sociais. A luta pelo espaço se dá ainda de forma coletiva, nas disputas de rumos da política de habitação, fonte do poder da construção política do espaço. Acima de tudo, as imagens de televisão emergem, de forma filtrada, a violência simbólica, isso fica patente no estudo de A miséria do Mundo. Por exemplo, o relato de Rickey, no gueto negro em Chicago, revela outras dimensões do lugar. Do mesmo modo e com singularidade, emerge a narrativa de um sem-teto do Harlem hispânico.

O habitus emerge nos lugares e na relação com seus efeitos. O exposto sinaliza o habitus como elo, ligação, intersecção entre o indivíduo/agente e o social/coletivo. Entre o agente e a realidade está o habitus. Não é uma função matemática do tipo linear, do tipo causa-efeito.

Um habitus gerou a luta dos NMS na história de Sapopemba, do CEDECA Sapopemba e em tantas conquistas naqueles territórios. Pela obra de FELTRAN (2011) surge uma amostra dos territórios de periferia de São Paulo no novo milênio.

Sob estes novos sóis emergirá outro habitus, novíssimos sujeitos sociais das periferias de São Paulo, na luta pelo direito à universidade?

\subsubsection{Pelos caminhos dos discursos dos novíssimos sujeitos sociais}

"A resposta de Bourdieu ao dilema do objetivismo/subjetivismo, com suas unilateralidades complementares, é dada a partir da sugestão de uma relação articulada entre estrutura, habitus e prática." (SOUZA, 2006, p. 43). Com essa pista, pisamos o chão do Brasil em 2003, mais especificamente num lugar chamado periferia de São Paulo, de modo mais próximo na zona leste de São Paulo, em seus extremos, nos bairros de Cidade Tiradentes, Cidade Antônio Estevão de Carvalho, conhecido como Cidade AE Carvalho, em Itaquera, e Guaianases e; na zona sul de São Paulo, no Jardim 
Ângela, onde localizam-se, em cada um desses bairros, um projeto de Cursinho Popular do MSU.

Os documentos, os textos, o corpus, objeto dessa pesquisa, originam-se da produção escrita feita exclusivamente por participantes desses projetos no gênero textual chamado argumentação. Como é notório, Cidade Tiradentes, AE Carvalho, Guaianases e o Jardim Ângela estão bem longe da periferia francesa, nos extremos da periferia paulistana, mesmo em relação ao bairro de Sapopemba. Mas, tanto Feltran (2011), como Bourdieu (2001), não são imbuídos de bairrismo algum e trazem contribuições conceituais fundamentais para essa pesquisa.

Os projetos de cursinhos populares do MSU na periferia foram uma conquista da luta pela universidade pública no Município de São Paulo, lei aprovada em fins de 2001 com o nome de Universidade da Cidade e da Cidadania de São Paulo. O epicentro mobilizador da luta foi a decisão política do MSU de colocar como prioridade em sua agenda de lutas, a transformação do Carandiru em Universidade, após uma grande rebelião ocorrida naquele presídio em 18 de fevereiro de 2001, e que invadiu os lares brasileiros ao vivo, naquele domingo à tarde, transmitido pelo programa popular de televisão "Domingo Legal", comandado pelo apresentador, que então tinha grande audiência popular, Gugu Liberato, quando os presidiários expressaram sua revolta com a superlotação e as condições desumanas no presídio, deixando ver a existência de uma organização política entre os presos. A disputa entre uma cultura de vida versus a cultura de morte animou a mobilização popular do MSU que passou a defender a criação de universidades públicas em parcerias entre o Município, o Estado e a União nos territórios norte, sul, leste e oeste de São Paulo, no próprio Carandiru ${ }^{50}$ e nas periferias.

A centralidade reivindicatória na questão do direito à universidade deu dimensão pública e autônoma ao MSU, um novíssimo movimento social.

Essa luta foi vitoriosa no parlamento municipal. Mas o projeto não sairia do papel por obra e graça da intervenção do Conselho Estadual de Educação, que impôs veto no ano de 2004. O apoio do poder municipal aos projetos de cursinhos populares do MSU foi fruto das discussões públicas oriundas das audiências públicas realizadas pelo Grupo de Trabalho Sobre a Questão Universitária em São Paulo, criado pela Portaria 135/2002 da Prefeita Municipal de São Paulo, publicada no Diário Oficial do

\footnotetext{
${ }^{50}$ Ver Jornal do Campus, 2001; Jornal da Tarde, 2001; Jornal O Estado de São Paulo, 2001.
} 
Município, onde o MSU participava paritariamente com quatro Secretarias Municipais, inclusive a Secretaria Municipal de Educação.

Nessa jornada de luta do MSU está o DNA da criação de um sistema público de bolsas de estudos, o que depois se chamaria PROUNI e da Universidade da Cidade e da Cidadania de São Paulo, que, repita-se, apesar de inaugurada pelo então Ministro da Educação Tarso Genro, com placa e tudo em Cidade Tiradentes no ano de 2004, teima em não sair do papel hoje ainda, dada aquela insidiosa decisão do Conselho Estadual de Educação (CEE).

Percebe-se que algo de novo se mexe no Brasil, novo no sentido sociológico, como percebeu tempos atrás Éder Sader em "Quando novos personagens entraram em cena" (SADER, 1988).

Tendo sobre as costas o fardo do desemprego neoliberal e sofrimentos equivalentes ou mil vezes mais doloridos (como se pudéssemos medir sofrimento humano) do que o caso francês, simplesmente porque no Brasil não houve mostras de um efetivo Estado do Bem-Estar social que abarcasse o grosso de sua gente, que dirá a classe trabalhadora de fora dos macacões azuis de antigamente, os negros, as negras, os indígenas, os brancos pobres esmagados pela partição da renda nacional muito desigual, que sob o império dos juros altíssimos, metáfora a um só tempo econômica e política, pois a economia é comandada pelas finanças globalizadas, cuja senha para atrair investimentos estrangeiros altamente voláteis e para garantir, simultaneamente, altas taxas de lucro para esses investimentos e estabilidade, é a elevada taxa de juros, que chega a ultrapassar a casa dos 50\%, situação que deixa a política subsumida pela economia, deixa a política de joelhos e impõe socialmente como corolário o desemprego em massa, nos fins dos noventa e no começo dos anos 2000.

Nesse deserto dos sonhos, jovens de todas as idades, suas famílias e conhecidos iniciam uma caminhada comum rumo à universidade, pelo direito à universidade, estão dispostos a tudo. Estudar muito, arrumar emprego, passar num concurso, melhorar de vida, por comida em casa e tirar da invisibilidade social brasileira sua dor.

Eles, elas participam do projeto cursinho popular do MSU em Guaianases, Cidade AE Carvalho, Cidade Tiradentes ou no Jardim Ângela. Todos, todas, são desempregados(as), esse é um dos critérios para participar do projeto, estão na faixa etária entre 16 e 29 anos de idade, outro critério objetivo para a participação. 
Próximo ao Jardim São Paulo, um bairro dentro de Guaianases, na rua Antonio Thadeo, 309, é noite de aula, de educação popular, no projeto cursinho popular do MSU.

Mas, há toque de recolher, por que um traficante considerado foi baleado num carro às portas do metrô Guaianases naquele dia do segundo semestre de 2003.

Descendo de metrô, estudantes universitários que pisam a universidade pública, sobem a rua enquanto os Sem Universidade aguardam passar a hora do toque de recolher para a lição da noite. O tio de um jovem marceneiro, de nome Ronaldo, emprestou a televisão e o vídeo para o debate da aula de geografia do cursinho popular.

Ronaldo, participante da pastoral da juventude do meio popular (PJMP) e coordenador do MSU, junto com um amigo carregam a televisão e estão parados na porta do centro de convivência, onde duas salas de aula foram improvisadas. A própria família do Ronaldo, moradora próxima, na avenida dos nordestinos, construiu as lousas e as cadeiras vieram de doação. Seus pais não fizeram universidade.

Um habitus emerge com laço social real. Algo diferente do que os pais e os pais dos pais fizeram. Eles lutaram contra a analfabetização imposta no Brasil. Esses novíssimos personagens pisam o chão da periferia, mas a luta dos Sem Universidade, na trilha deixada por Paulo Freire e Abdias do Nascimento, agora é pelo direito à universidade.

Melhor enxergar diretamente no mapa da cidade de São Paulo esses lugares onde se acham as experiências de educação popular do MSU, os cursinhos populares do MSU, onde estão os Sem Universidade. É o que se segue: 
Figura 3 - Georreferenciamento - distribuição geográfica no município de São Paulo (SP) do local de moradia dos Sem Universidade participantes do projeto de educação popular, do cursinho popular do MSU na zona leste de São Paulo, em Guaianases, localizado na Rua Antonio Thadeo, 309 (2003)

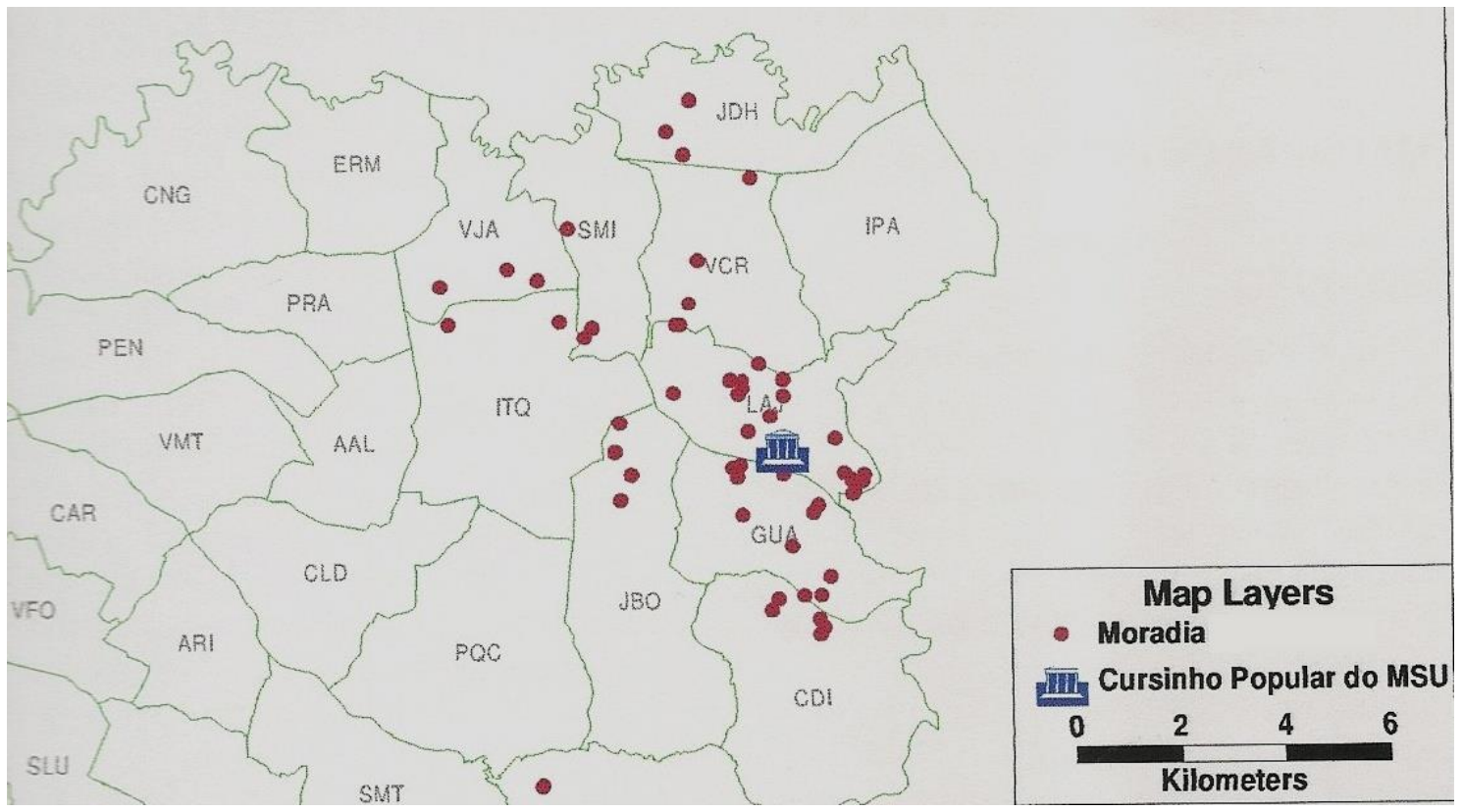

Fonte: Acervo MSU.

Figura 4 - Georreferenciamento - distribuição geográfica no município de São Paulo (SP) do local de moradia dos Sem Universidade participantes do projeto de educação popular, do cursinho popular do MSU na zona sul de SÃO PAULO, no Jardim Ângela, na Rua Marcelino Coelho, 297 (2003)
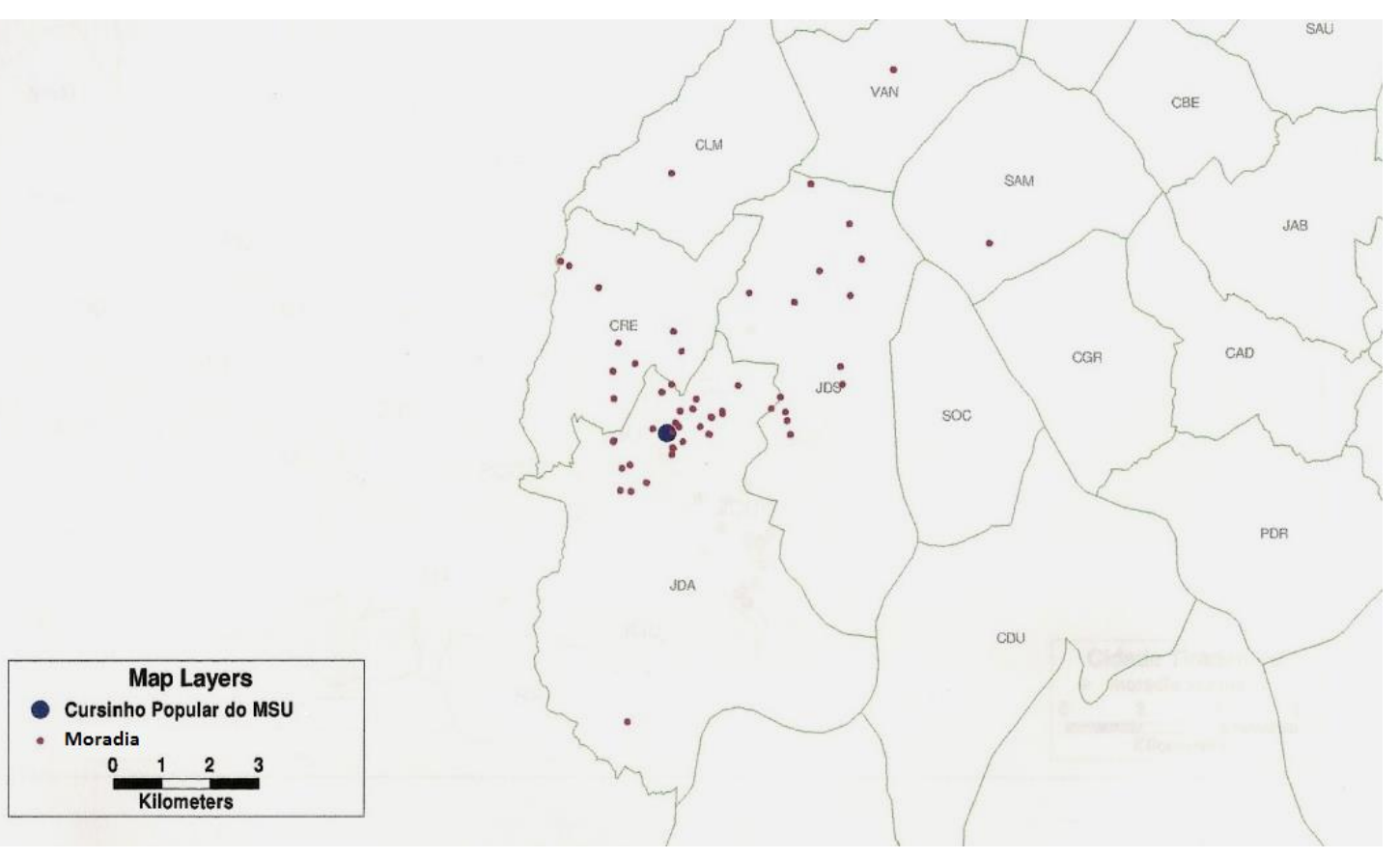

Fonte: Acervo MSU (2003). 
Figura 5 - Georreferenciamento - distribuição geográfica no município de São Paulo (SP) do local de moradia dos Sem Universidade participantes do projeto de educação popular, do cursinho popular do MSU na zona leste, em Cidade AE Carvalho, na Avenida das Alamandas, 36 (2003)

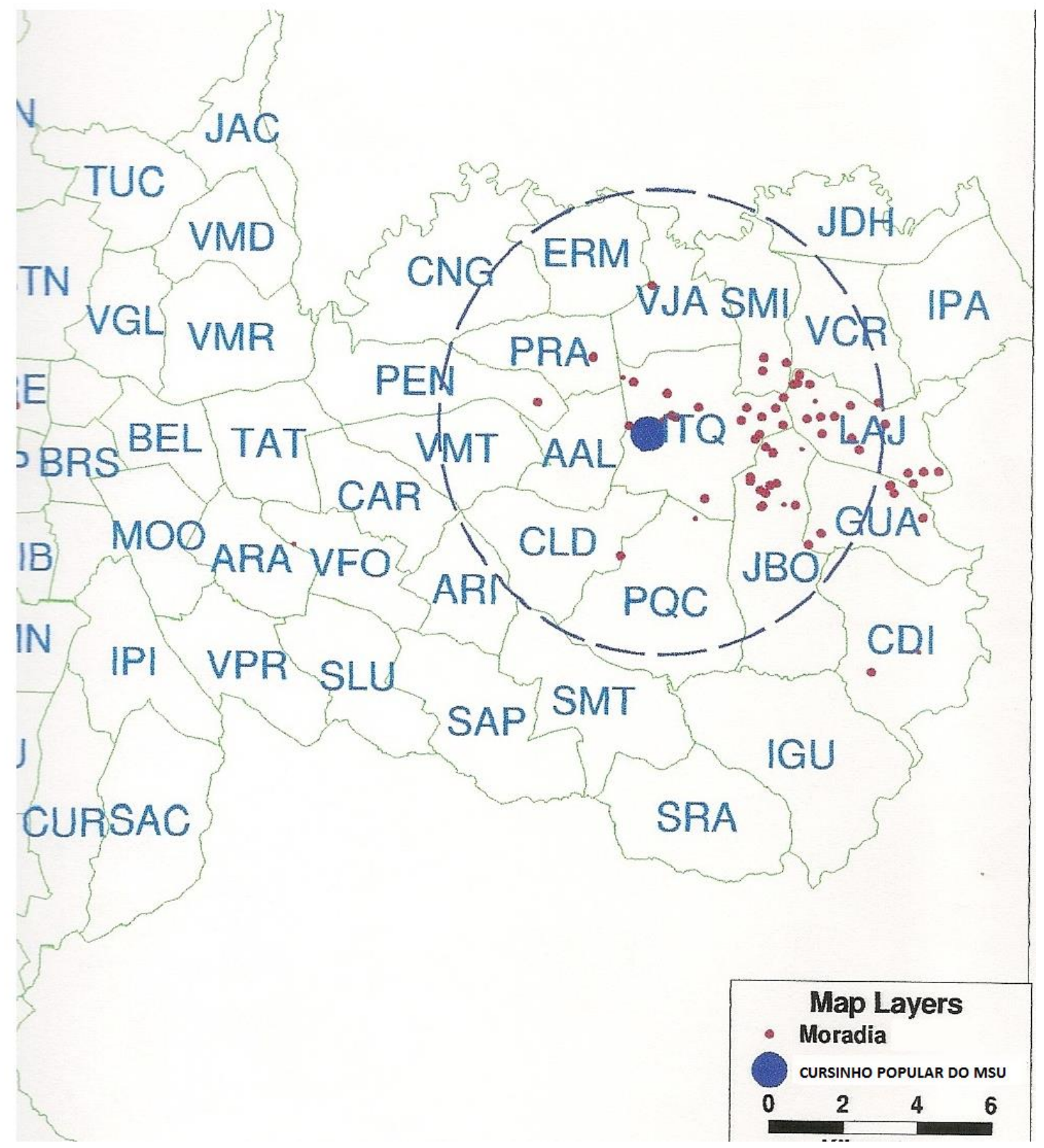

Fonte: Acervo MSU (2003). 
Figura 6 - Georreferenciamento - distribuição geográfica no município de São Paulo (SP) do local de moradia dos Sem Universidade participantes do projeto de educação popular, do cursinho popular do MSU na zona leste, em Cidade Tiradentes, na Avenida dos Têxteis, 2907 (2003)

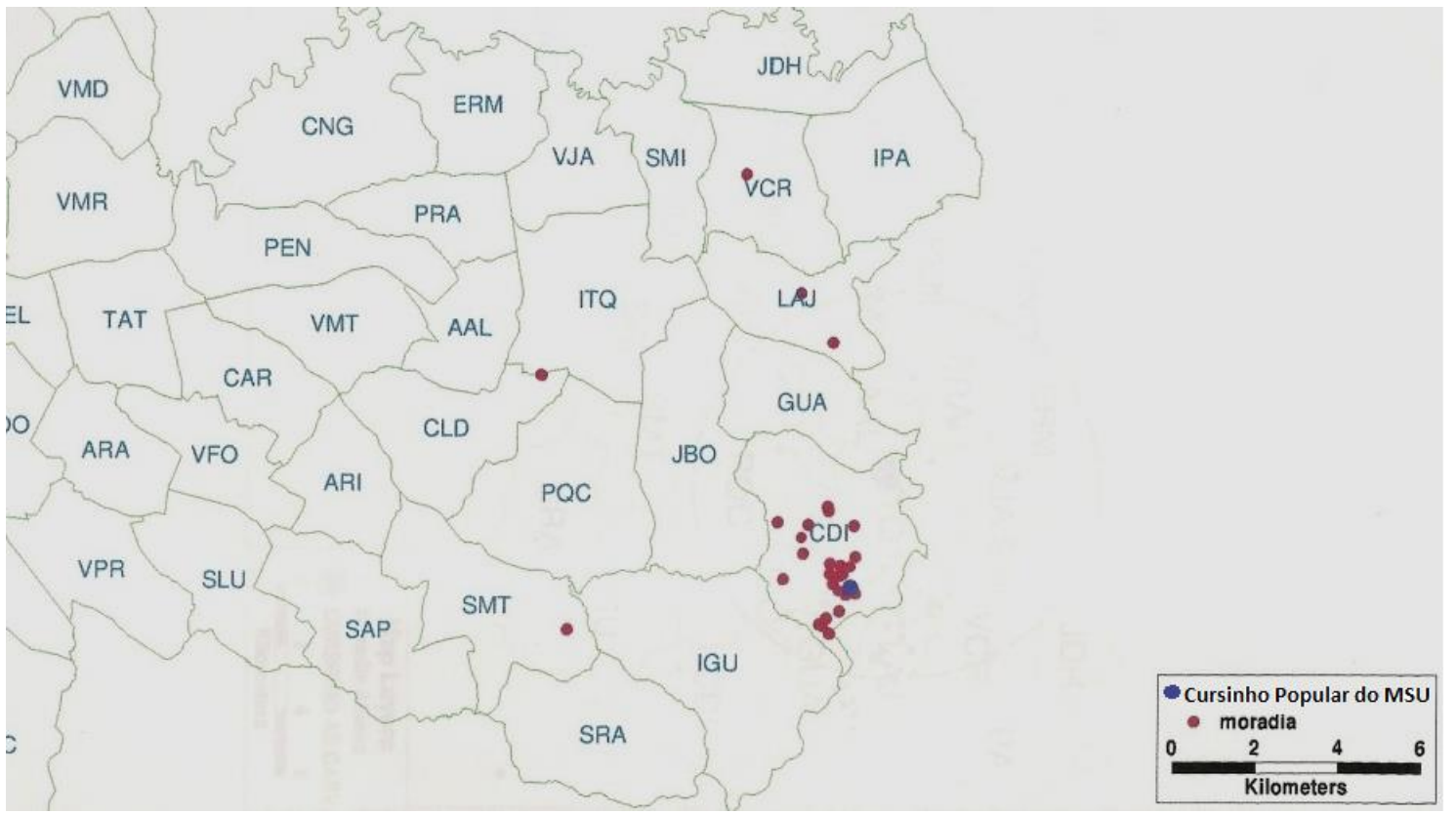

Fonte: Acervo MSU (2003).

Os locais e horários de funcionamento do Projeto de Educação Popular, do Cursinho Popular do MSU, em 2003, eram os seguintes:

Aulas de segunda à sexta feira, das $19 \mathrm{~h} 30$ às $22 \mathrm{~h} 45$ :

- Jardim Ângela: Rua Marcelino Coelho, 297.

- $\quad$ Cidade Tiradentes: Avenida dos Têxteis, 2.907.

- $\quad$ Guaianases: Rua Antonio Thadeo, 309.

Aulas aos sábados e domingos, das 08h30 às 17h15:

- $\quad$ Cidade AE Carvalho: Av. das Alamandas, 36.

Surge a pergunta da necessidade do entendimento da ação sociológica e cultural destes agentes no campo educacional brasileiro, ainda que bem à margem, quase invisíveis. Entendimento de seus discursos. Mas seus rastros, os desses novíssimos personagens da história do Brasil, advindos das classes ditas $\mathrm{C}, \mathrm{D}$ e $\mathrm{E}^{51}$ e que, muitos

\footnotetext{
${ }^{51}$ Reduzir classe social a classe de consumo é uma atitude de laivo fascista e castradora: da imaginação e da cidadania. A nota $\mathrm{C}$ nas escolas públicas brasileiras era a nota limite para "passar de ano", as notas D e $\mathrm{E}$ indicavam reprovações. Trocar o $\mathrm{C}$ de cidadania pelo $\mathrm{C}$ de consumo traz outro terrível ingrediente junto, de cambulhada: a busca de mimetização do comportamento histórico das chamadas classes médias brasileiras no seio das classes trabalhadoras, um feitiço bom para vários negócios. Isso não significa que o consumo não seja um direito da classe trabalhadora, que a elevação dos padrões de consumo não seja em si um bem. Isso é uma coisa, outra coisa distinta é a criação de mercados artificiais para todo tipo de produto, como educação, saúde etc., de olho no "brilho dos olhos", melhor, dos bolsos e orçamentos
} 
deles, pela primeira vez em suas famílias, tentam chegar até a universidade, estão na estrada da história do Brasil recente.

Um conjunto de dados objetivos dá cara a isso, documenta isso, é o corpus dessa investigação, formado por um questionário cultural com sete perguntas objetivas, uma proposta de redação para a produção de um texto argumentativo, os rascunhos da redação e os textos feitos e doze questões dissertativas do núcleo básico de conhecimento do ensino médio brasileiro. Há complementarmente outras semioses.

No documento, no corpus, como se verá adiante com maior pesar, a cena discursiva se amplia, muita coisa aparece, de variados modos:

1) Indício de mudança de postura cultural, com relação a livros e filmes;

2) Pistas de inequívoca movimentação de negros e negras em direção à universidade.

3) Forte presença feminina em busca de carreira profissional através do ensino superior;

4) Pegadas de mudança no hábito de estudo planejado;

5) Sinais da busca de superação dos anos de estudos dos pais;

6) Rastros de bandeiras coletivas, de causas coletivas;

7) Gotas de suor do enfrentamento da violência simbólica cotidiana, onde a estatística do número de pais falecidos pode indicar várias coisas;

8) A luta social que vai às ruas, ao parlamento, ao poder executivo, ao poder judiciário, para disputar políticas e garantir o direito à universidade para o povo.

Pode-se falar em novíssimos sujeitos sociais no Brasil? É o que se divisa para a investigação. É ver para crer.

dessas famílias. Como se a educação privada das elites virasse sonho, por exemplo, e, passasse como mágica a ocupar no imaginário popular o lugar do direito a uma educação pública de qualidade, reforçando preconceitos educacionais e ilusões irreais, e, por tabela, deslocando o investimento público da educação pública, gerando novas disputas pelo fundo público da educação e organizando vastos mercados para novos produtos educacionais ou velhos, se o queiram. 
A produção dos textos dos agentes no gênero do discurso avaliação de conhecimento ocorreu numa situação formal, típica de exames no geral. Todos os textos, rigorosamente foram produzidos sob as mesmas condições objetivas: local próprio comum, silêncio, tempo determinado, tema conhecido apenas no momento da produção textual.

A entrega do texto feito, do documento completo, incluindo rascunhos, somente foi autorizada ao final de um tempo mínimo de duas horas e máximo de quatro horas desde o horário de início da avaliação de conhecimento.

Essa dissertação engloba o conjunto dos documentos. São 360 ao todo. A análise do discurso recai sobre uma amostra desse universo, abarcando a redação proposta e duas questões dissertativas: a de número um e a de número cinco.

Para o desenvolvimento da redação, foi fornecida como base de apoio comum uma coletânea de textos com diferentes opiniões sobre o direito à universidade no Brasil, a partir de excertos de textos assinados ou de entrevistas concedidas por autoridades da área de educação no Brasil, extraídos de publicações reconhecidas da grande imprensa escrita brasileira no ano de 2003.

Esses textos juntos indicam a mediação epistêmica direta para a produção dos textos dos agentes, pois servem como o referencial de mediação de saber para a produção textual.

Sua temática e abrangência, extraída como rico documento, como parte do corpus, selecionou, na prática, um horizonte possível para a escolha do tipo de espaço discursivo pertinente ao corpus, o que recaiu, como visto anteriormente, sobre o espaço discursivo das relações raciais no Brasil, considerando aspectos sociais, culturais, econômicos e políticos.

Nessa parte da dissertação são arrolados a íntegra destes textos que servem como mediação epistêmica direta e depois, é desenvolvido uma análise do discurso presente nestes textos vis-à-vis os discursos constituintes do espaço discursivo das relações raciais no Brasil.

São os seguintes os textos:

Texto 1: 
Nós consideramos que o vestibular implica um processo que constitui uma barreira intransponível para estudantes de renda menor.

Por exemplo, uma pesquisa feita no último exame de seleção da UFRJ (Universidade Federal do Rio de Janeiro), mostrou que 70\% dos inscritos são oriundos de escolas públicas, mas entre os aprovados, o índice cai para cerca de $30 \%$. Então, quem tem mais mérito: um estudante da rede pública de ensino, proveniente de uma família de renda mais baixa, que estudou em condições precárias, chega no vestibular e tira nota 6 , ou um estudante que veio das melhores escolas, de uma família rica, e tirou 8? Não tem como dizer que um tem mais mérito que o outro porque as circunstâncias são inteiramente diversas.

Proponho que haja um sistema de avaliação que acompanhe o estudante ao longo de toda a sua vida escolar, levando em conta as condições da escola e do meio em que ele vive. Não é um sistema de cotas. Eu não gosto da ideia de cota porque ela mantém o vestibular, e mantendo o vestibular sempre haverá um padrão de desigualdade. Se você estabelece outro critério de acesso elimina a possibilidade de um aluno que tirou nota maior e foi ultrapassado por um de nota menor ir à justiça ${ }^{52}$.

Texto 2:

Texto 3:

O Ministro da Educação Cristovam Buarque pode estender para todo o país o chamado PAS (Programa de Avaliação Seriada), sistema que é usado na Universidade de Brasília desde 1996 em substituição ao vestibular. Ele é diferente do ENEM (Exame Nacional do Ensino Médio).

$\mathrm{Na}$ avaliação seriada, os estudantes fazem uma prova no fim de cada ano do ensino médio, somando o resultado das três quando concluem o curso.

Cristovam afirmou também que as cotas para negros nas universidades não resolvem a desigualdade social no país. Pessoalmente se diz favorável à implementação do sistema. Mas, como ministro, quer esperar os resultados das experiências atuais (Rio de Janeiro, Bahia e Brasília) e as consequências perante a opinião pública ${ }^{53}$.

Texto 4:

O processo seletivo - o vestibular - e o sistema de avaliação do ensino médio - o ENEM ou o PAS - devem ter uma clara distinção entre eles, pois os objetivos são diferentes.

Acho o sistema de avaliação continuada uma proposta mais adequada, pois oferece uma visão mais completa sobre o desenvolvimento estudantil do ensino médio. O sistema pode ser usado como parte do vestibular.

Quanto às cotas, acho que são um primeiro passo para tornar visível o tema da discriminação social. Elas criam também a possibilidade de os afrodescendentes assumirem uma representatividade maior nas camadas gestoras da sociedade. Usar o argumento de que os negros devem enfrentar o vestibular e ingressar na universidade por uma questão de mérito é desconhecer as condições anteriores a essa entrada no ensino superior ${ }^{54}$.

Acho o sistema de cotas errado. As ações devem começar antes do ingresso nas universidades, como a criação de cursos pré-vestibulares gratuitos.

\footnotetext{
${ }^{52}$ Aloísio Teixeira, reitor da UFRJ. Publicado no jornal O Estado de São Paulo, 19 de julho de 2003.

${ }^{53}$ Luis Renato Strauss, jornalista. Publicado no Jornal Folha de São Paulo, E5, 10/07/2003.

${ }^{54}$ Mário Sérgio Cortella, doutor em educação e professor em pós-graduação da PUC-SP. Publicado no Jornal Folha de São Paulo em 10/07/2003.
} 
Texto 5:

O atual sistema permite a entrada de pessoas com deficiência de formação, o que pode acarretar reprovação em massa desses estudantes, perda de qualidade dos cursos e, até mesmo, o mercado considerar o profissional menos capaz.

Caso seja ampliado para quatro anos o ensino médio, acredito que não existiria estrutura e um pessoal adequado para atender a demanda que seria criada por essa alteração ${ }^{55}$.

Em agosto, pró-reitores de graduação das universidades de São Paulo (USP), Estadual Paulista (UNESP) e de Campinas (Unicamp) apresentarão uma proposta para mudar o sistema de seleção atual. A modificação permitiria aos estudantes pagar só uma taxa de inscrição.

Segundo a pró-reitora de graduação da USP, Sonia Penin, a mudança, se aprovada, só ocorrerá no fim de 2004. "Se, por um lado, os gastos com a inscrição e desgaste físico e emocional diminuem, por outro a probabilidade de acesso também sofrerá modificações", diz o diretor acadêmico da VUNESP, Fernando Prado.

No lugar do sistema de cotas, a pró-reitora da USP defende um quarto ano opcional ao ensino médio público que preparasse o jovem para o vestibular. "Não adianta selecionar um aluno que depois não conseguirá acompanhar bem o curso",56

Texto 6:

O Ministro da Educação, Cristovam Buarque, costuma catalogar todas as visitas que recebe e descobriu o seguinte: de janeiro até agora deu audiência a 211 parlamentares, entre deputados e senadores. Dá uma média de dois a cada dia de trabalho. Segundo o ministro, $70 \%$ dos deputados o procuram para defender interesses de faculdades particulares. Como se sabe, apenas $15 \%$ dos estudantes brasileiros estão matriculados no ensino superior57.

\section{Texto 7:}

Faz pouco tempo, uma organização particular de ensino superior quis homenagear a apresentadora Hebe Camargo, concedendo-lhe o título de doutora honoris causa. O que há de estranho neste gesto não é tanto o fato de estar reverenciando uma personalidade do "show business". O aspecto inusitado dessa ação entre amigos se prende à pretensão de autoridade cultural dos dirigentes da empresa educacional, cujos anúncios de página inteira na imprensa não veiculam importantes feitos ou descobertas em matéria científica. (...) A notável expansão dos investimentos privados no ensino superior, nos últimos 15 anos, o estardalhaço com que seus acionistas promovem eventos sobre sua chancela, sem falar no fabuloso faturamento, terá decerto de suscitar reflexão a respeito de seu ínfimo apetite por pesquisa ou projetos de fôlego nas áreas pouco rentáveis do ensino superior. A prioridade quase exclusiva dos novos Midas do saber "delivery" são os cursos e carreiras que prometem perspectivas de profissionalização imediata $^{58}$.

\footnotetext{
${ }^{55}$ Eunice Ribeiro Durham, ex-secretária de educação superior do MEC e pesquisadora do NUPES (Núcleo de Estudos Sobre Ensino Superior da USP). Publicado no Jornal Folha de São Paulo em 10/07/2003.

${ }^{56}$ Daniella Tófoli, jornalista, Publicado no Jornal O Estado de São Paulo, 30/07/2003.

${ }^{57}$ Alexandre Secco, jornalista, publicado na revista Veja, página 32, edição número 1812, 23/07/2003.

${ }^{58}$ Sérgio Miceli, professor titular de sociologia da USP. Publicado no Jornal Folha de São Paulo, no artigo chamado "A universidade Pública a Perigo", na página A3, em 18/07/2003.
} 


\subsubsection{Análise dos discursos presentes na mediação epistêmica direta}

Os textos diversos presentes na mediação epistêmica direta podem ser vistos, com relação à fundamentação teórica, aos discursos constituintes, ao quadro de restrição semântica e aos discursos de Uns versus Outros, majoritariamente pendentes para o discurso de Uns, portanto mobilizadores dos semas da /ordem/, da /segregação/, da /homogeneidade/, da /concentração/, da /unidade/, não em uníssono.

Há nuances evidentes, mas a mediação epistêmica defende o status quo. A invisibilidade é patente em muitos dos discursos: do discurso dos povos indígenas, dos indígenas, que simplesmente não aparecem. É a forte lei tácita do silêncio.

A palavra cota substitui, em muitos dos discursos o negro, a negra, uma das etnias da desigualdade. O texto 4 e o texto 5 negam as cotas, ambos culpam as vítimas do sistema de educação nacional pela exclusão da universidade: em T5 apare "o aluno não conseguirá acompanhar bem o curso", aparece o discurso da democracia racial, que quando questionado por uma situação-problema objetiva, descarrega os dedos na inferioridade dos Outros sociais, implicitamente, os negros, os indígenas, os pobres, os oriundos da escola pública, os moradores de periferia. O discurso em T5 serve como escudo para manter a ordem, o status quo. Remete diretamente ao discurso de Uns sobre Outros. Não se faz a defesa da escola pública, por tabela, torna-se explícita a defesa da posição de classe, do ensino particular.

Em T4 o julgamento ganha ar de argumento puro de autoridade: "acho o sistema de cotas errado". Com isso levanta-se o bastião da defesa do status quo, do discurso de Uns frente ao "perigo" dos Outros e aperta o gatilho discursivo sobre os outros corpos, bebendo na fonte quase eternas do discurso da democracia racial no Brasil e suas (re)semantizações convenientes, o que camufla o preconceito, o racismo: fala-se em "perda da qualidade dos cursos" e "profissional menos capaz". Nada se diz sobre a escola pública, defende-se a casa-grande, a escola particular, implicitamente, coincidentemente a casa dos brancos, suas famílias e estudantes.

Mas T4 indica um sintoma do retumbante discurso da ordem no sistema de educação nacional: a terapia recomendada para os Outros sociais é a "criação de cursos pré-vestibulares gratuitos" como políticas de educação. É uma velha prática educacional 
que vem de quando era proibido o estudo aos Outros sociais, no tempo da escravização de africanos no Brasil. A Lei Geral do Ensino, de 1827, criaria os cursos jurídicos no Brasil em Olinda e São Paulo, que viraria o curso de direito do Largo São Francisco, tal lei exigia que "os estudantes que quiserem se matricular nos cursos jurídicos [...] mostrem ter a idade de 15 anos completos, e de aprovação da língua francesa, gramática latina, retórica, filosofia racional e moral e geometria”, para aferir o domínio dessas matérias foram criados os exames e os peritos, logo, está na raiz do sistema de educação no Brasil como ele nasceu a origem da perversão: os cursos de preparatórios, parte do ritual da exclusão dos Outros da educação no Brasil e afirmação do status quo de Uns. Informa Marcílio (2005, p. 75),

os exames de preparatórios para julgamento das habilitações dos candidatos passaram a ser: latim, francês, inglês, retórica, filosofia racional e moral, aritmética e geometria, história e geografia. Foram então criados os Colégios de Artes, os malfadados cursos de preparatórios aos cursos jurídicos no país e anexos às duas Faculdades de Direito: foram conhecidos também por "aulas menores". [...] a reorganização das duas escolas superiores médicocirúrgicas (do Rio e da Bahia), fundadas por d. João VI, que passaram a denominar-se Faculdades de Medicina; os cursos e exames preparatórios foram estendidos para elas também. [...] Os exames de preparatórios foram fatores negativos para o aperfeiçoamento e mesmo para o estabelecimento do ensino secundário graduado no Brasil.

Assim, a terapia do cursinho pré-vestibular, agora para os Outros, é jogo de esconde-esconde histórico da questão racial, dos Outros, indígenas, negros, brancos pobres no Brasil, jogo macabro de exclusão da universidade pública. Essa opção de política educacional sobreviveria no tempo no país sem um sistema nacional de educação pública de fato, onde ela fez famas e fortunas no Brasil no século XX, avançou sobremaneira a sua penetração com o grande empurrão histórico dado pela Ditadura Militar no período de 1964-1985 nas siglas que tocavam esse negócio do ensino privado nacional e que se esparramariam para níveis inferiores e superiores da educação privada em sua diversificação, o que se viu também nos anos de ouro do neoliberalismo dos 1990, até seus grandes capitalistas transformarem-se em rentistas "aposentados", essas siglas virarem sistemas de educação e seus capitais serem financeirizados no mercado mundial de ações na atualidade.

Em T1 há o questionamento sério da noção de mérito, presente no discurso de Uns, há uma questão de classe explícita por o locutor defende a escola pública e aponta o desnível de renda. Mas, passa ao largo da questão racial, com um argumento distinto sobre o sistema de cotas "Eu não gosto do sistema de cotas porque ele mantém o vestibular", mas não aponta outra saída, nem adentra nas dimensões históricas que o 
tema cotas engendra. Seu silêncio sobre a questão é ensurdecedor, dada sua posição de poder, trata-se de um reitor num estado com forte presença negra e presença indígena relevante ao longo de sua história.

T5 também aponta a modificação cosmética nas propostas dos reitores: "pagar uma só taxa de inscrição", ao gosto do discurso de Uns, da ordem, segregando e não integrando os Outros sociais, raciais. Lembra o "para inglês ver" ou a "abolição lenta, gradual e indenizada" ou a "saída lenta, gradual e segura da ditadura de 21 anos". Discurso cosmético porque longe dos direitos historicamente negados do acesso à universidade, ainda mais quando é patente que as universidades públicas paulistas são diretamente financiadas com impostos do ICMS, cuja base social maior de incidência é sobre a massa trabalhadora, sobre os moradores da periferia.

As mediações de T2 e T5 revelam o discurso do equilibrista no exercício do poder central no Ministério da Educação no Brasil, pressionado pela maioria parlamentar liberal da bancada graúda do ensino privado e, ao mesmo tempo, numa espécie de sítio de um novo governo federal que tem pressa para dizer a que veio, mas tem amarras contraditórias com o andar de baixo e o andar de cima da sociedade, mas acima de tudo é um discurso que não assume os riscos políticos de defender as cotas enquanto Ministro, mas apenas enquanto homem, talvez pela correlação de forças na esplanada. Ao citar um modelo ideal, a extensão do PAS, o discurso do locutor deslocase da realidade de um país que não tem um sistema nacional de educação articulado, o que inviabiliza, de saída, tal ação. Ao posicionar-se pessoalmente favorável as cotas e apontar as experiências em andamento o locutor assume o discurso dos Outros, talvez a espera da devida oportunidade política ou do lento convencimento dos interesses num país continental.

Já T3 é o único texto que assume de modo explícito o discurso dos Outros. O locutor expõe a importância da história, indica a presença da história e defende as cotas, pois "criam também a possibilidade de os afrodescendentes assumirem uma representatividade maior nas camadas gestoras da sociedade". Isso remete ao discurso histórico da negritude, da igualdade racial, onde não há a ideia presente em T4 e T5 do outro como o inferior.

Por seu turno, T7 expõe as feridas do conflito distributivo público versus privado no ensino superior brasileiro e alerta sobre o "perigo" contra as universidades públicas, valendo-se o locutor de um caso alegórico. Contudo, ele não problematiza o público como ele é e não aponta as intersecções e pontes entre o público e o privado, como se 
fossem universos paralelos. Como ele é, o público é indefensável, pois justamente não é público, pois não tem o negro, a negra, o indígena, a escola pública, em todas as carreiras e cursos. Revela um discurso de vanguarda de elites intelectuais ensimesmadas, onde o apoio popular vale como caudatário automático do poder do mérito acadêmico. O locutor não adentra nas contradições da universidade pública como ela é.

Assim, as mediações epistêmicas vistas, indicam um campo demarcado para o discurso dos agentes, que terão que falar nas riscas de cal de um conflito discursivo instalado, valendo-se de suas heranças culturais e de suas trajetórias escolares, da posse relativa de capitais culturais, de relações e do habitus de suas práticas discursivas que ora são colocadas à prova.

\subsection{A mediação perceptiva indireta}

Se a mediação epistêmica direta guarda relação com o universo do saber diretamente fornecido para a produção textual, em sua epiderme, outras mediações são possíveis e, em algum grau, elas influenciam a produção textual, o fazer discursivo, como é o caso de mediações perceptivas indiretas, que fazem parte do corpus, do acervo documental. Elas estão presentes no questionário sociocultural. Uma vez que a dissertação considera seriamente a perspectiva do paradigma indiciário (GINZBURG, 1976) não se poderia "passar batido" por cima desses sinais que estão presentes no documento, no corpus, pois eles podem auxiliar a análise dos discursos dos sujeitos, pois repertoriam indícios consideráveis para tanto.

No início da avaliação de conhecimento, base da documentação, faz-se presente um questionário socioeconômico, que foi preenchido por todos os agentes obrigatoriamente, no começo da avaliação, com verificação carteira por carteira da documentação individual respectiva de identidade.

Por conta disso, como parte do acervo documental, tem peso relativo importante para a investigação.

Perpassando a integridade dos 360 documentos que compõe a totalidade do corpus esse estudo considera, evidenciam-se alguns aspectos que remetem ao espaço 
discursivo das relações raciais no Brasil, a disposições culturais e heranças culturais dos agentes. Esses dados foram reunidos e sistematizados nas formas que aparecem a seguir e indicam pontos importantes para a reflexão sobre a responsabilidade discursiva dos agentes/sujeitos, à medida que, indiretamente, significam o pano de fundo de aspectos da realidade do conjunto dos agentes geradores da documentação, portanto um retrato desses agentes na história. É o que segue.

Figura 7 - Raça/Cor autodeclarada dos Sem Universidade participantes do projeto de educação popular, do cursinho popular do MSU em 2003.

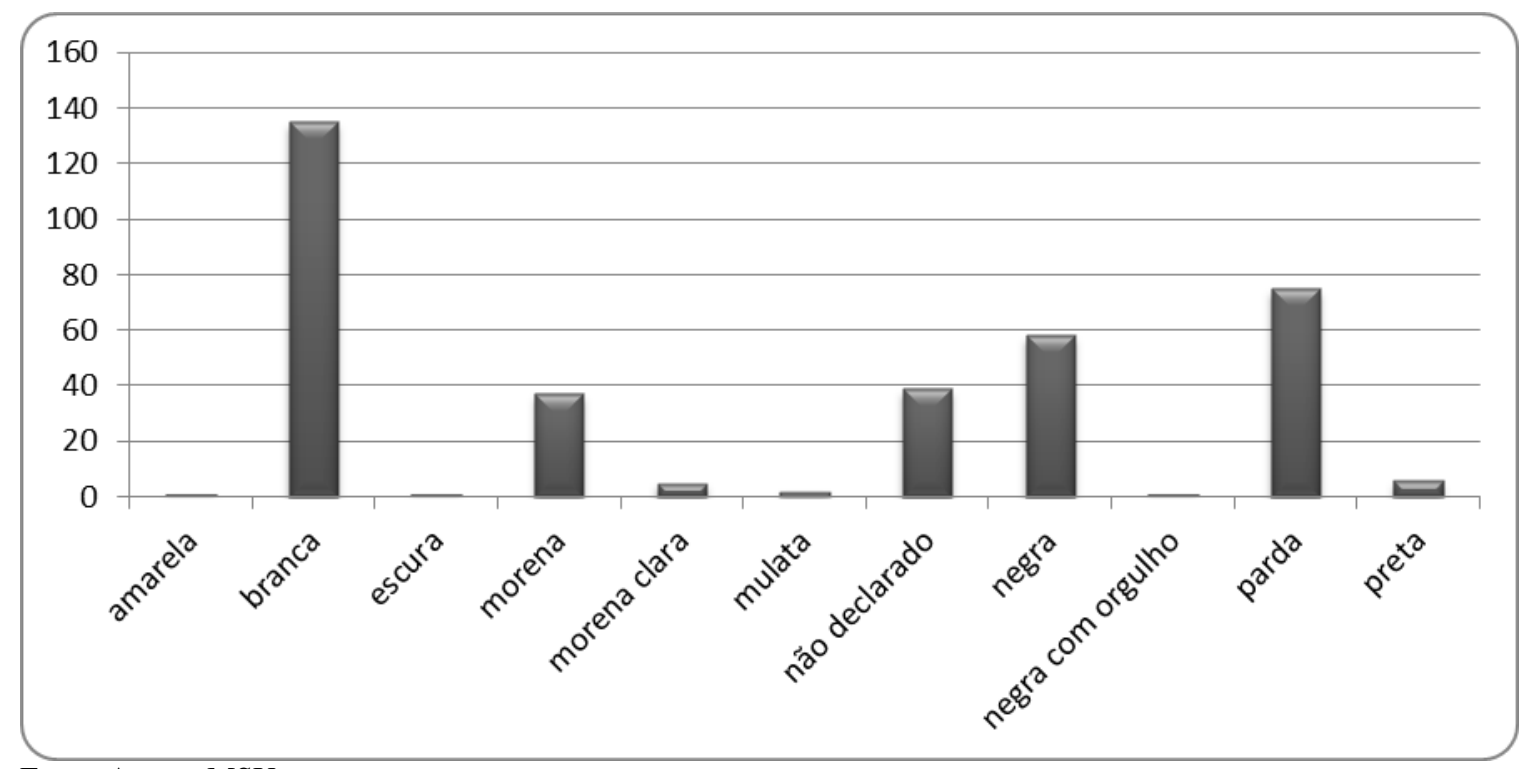

Fonte: Acervo MSU.

Figura 8 - Raça/Cor conforme o IBGE apropriado da figura 7 da autodeclaração dos Sem Universidade participantes do projeto de educação popular, do cursinho popular do MSU em 2003

\section{Cor/Raça IBGE}

घpreta amarela $\square$ branca $\square$ parda não declarado

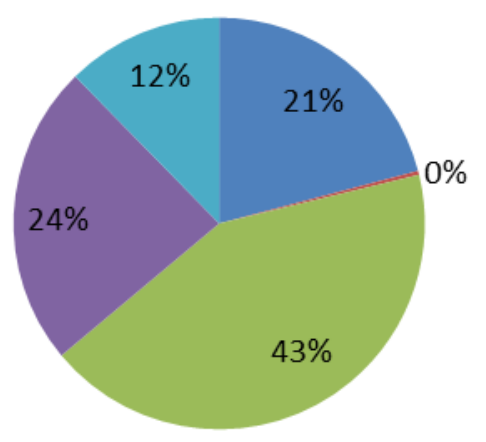

Fonte: Acervo MSU. 
Figura 9 - Distribuição da chefia de família conforme autodeclaração dos Sem Universidade participantes do projeto de educação popular, do cursinho popular do MSU em 2003

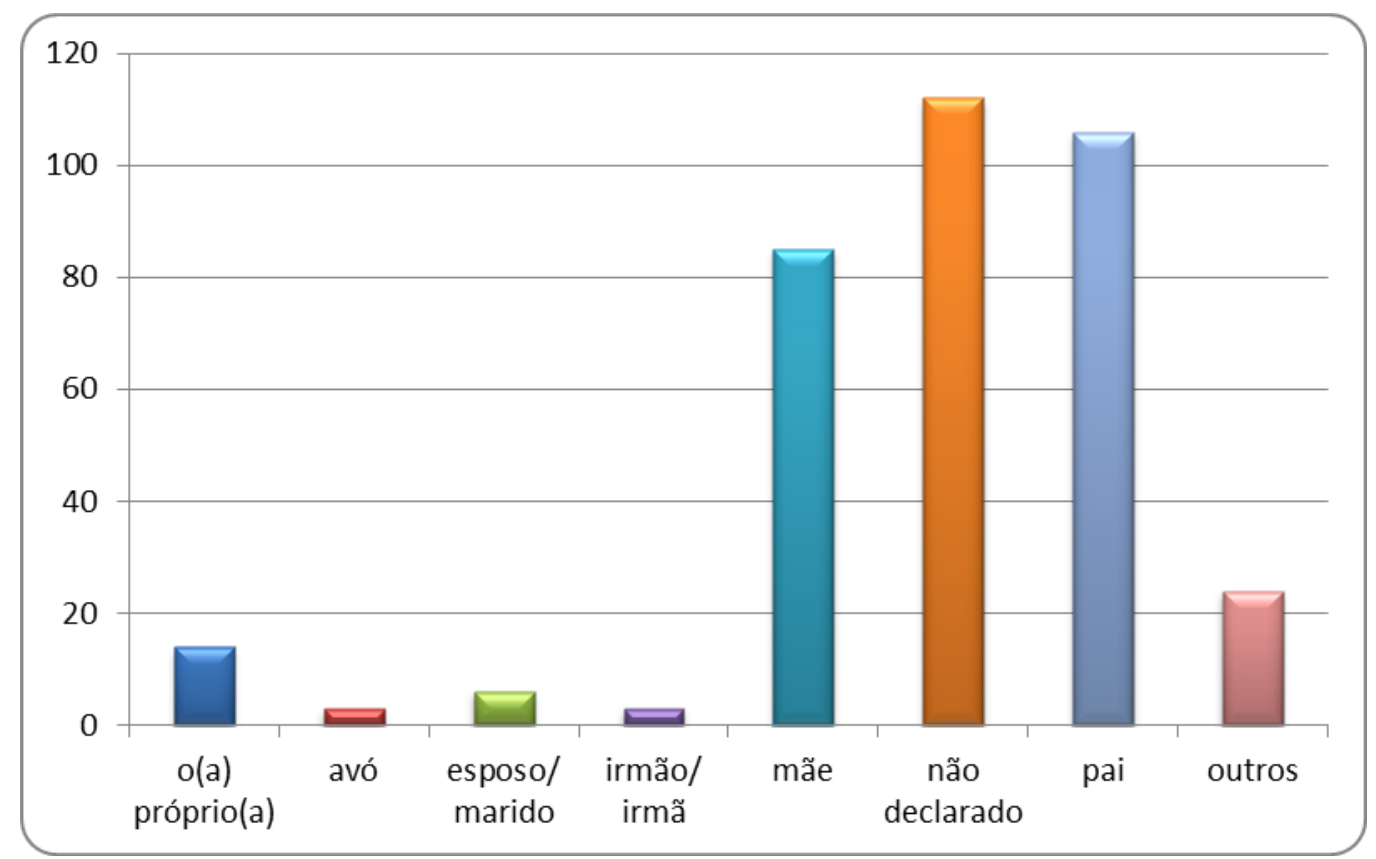

Fonte: Acervo MSU

Figura 10 - Sexo conforme autodeclaração dos Sem Universidade participantes do projeto de educação popular, do cursinho popular do MSU em 2003

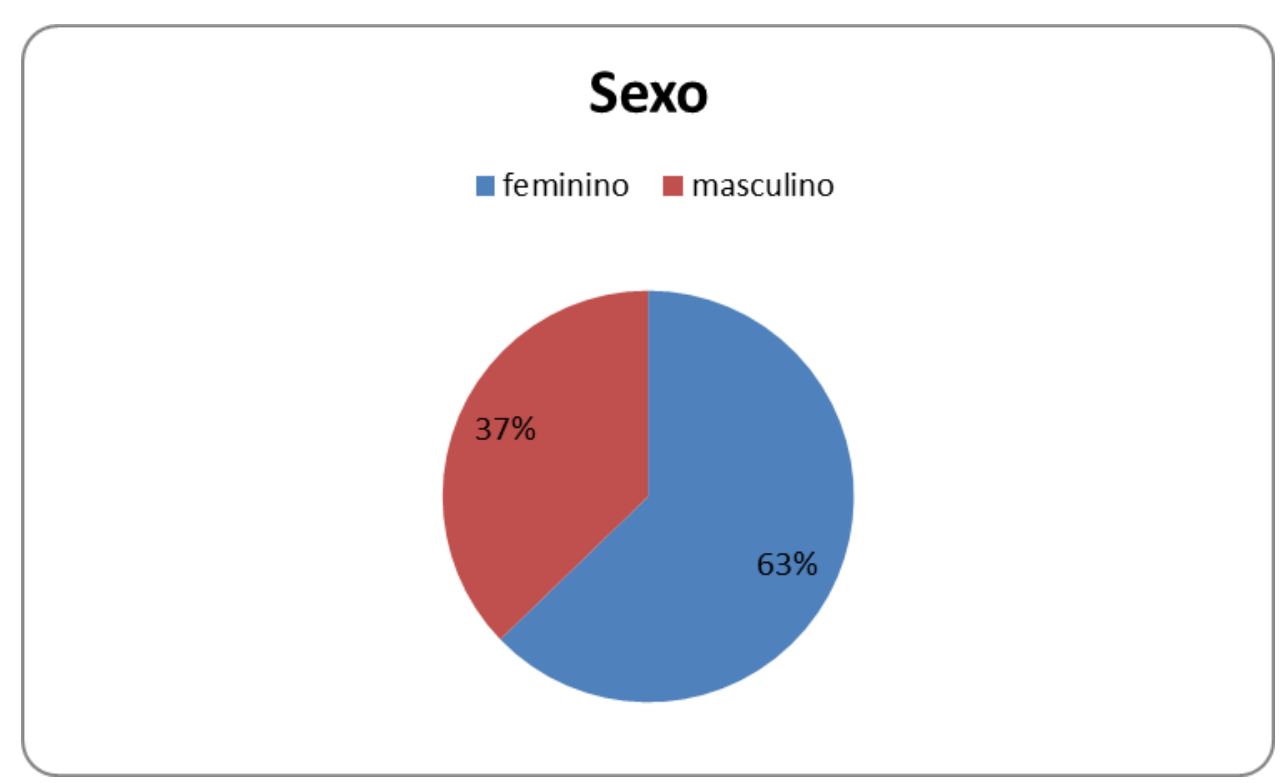

Fonte: Acervo MSU. 
Figura 11 - Origem escolar pessoal conforme autodeclaração dos Sem Universidade participantes do projeto de educação popular, do cursinho popular do MSU em 2003

\section{Escola em que estudou predominantemente}

não declarado aparticular aública meio a meio

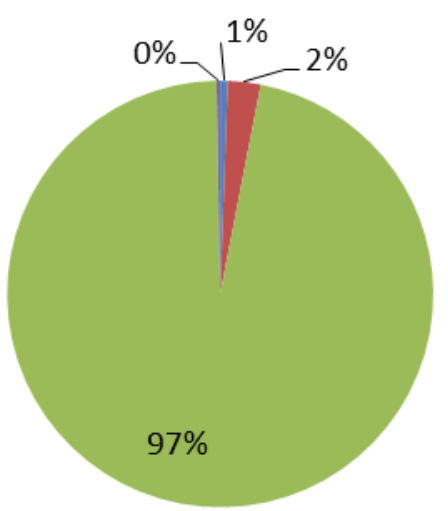

Fonte: Acervo MSU.

Figura 12 - Escola em que concluiu o ensino médio conforme autodeclaração dos Sem Universidade participantes do projeto de educação popular, do cursinho popular do MSU em 2003.

\section{Escola em que concluiu o Ensino Médio}

não concluiu não declarado $\quad$ particular $\quad$ pública

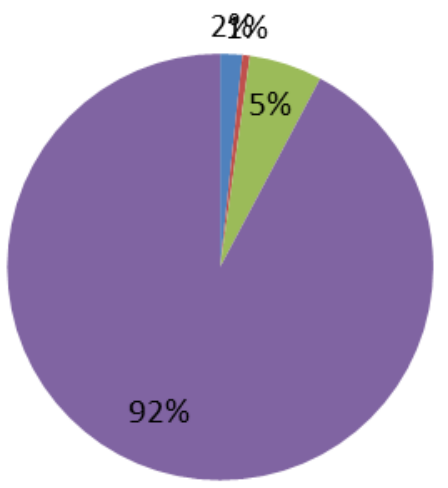

Fonte: Acervo MSU. 
Figura 13 - Formação escolar da Mãe conforme autodeclaração dos Sem Universidade, participantes do projeto de educação popular, do cursinho popular do MSU em 2003

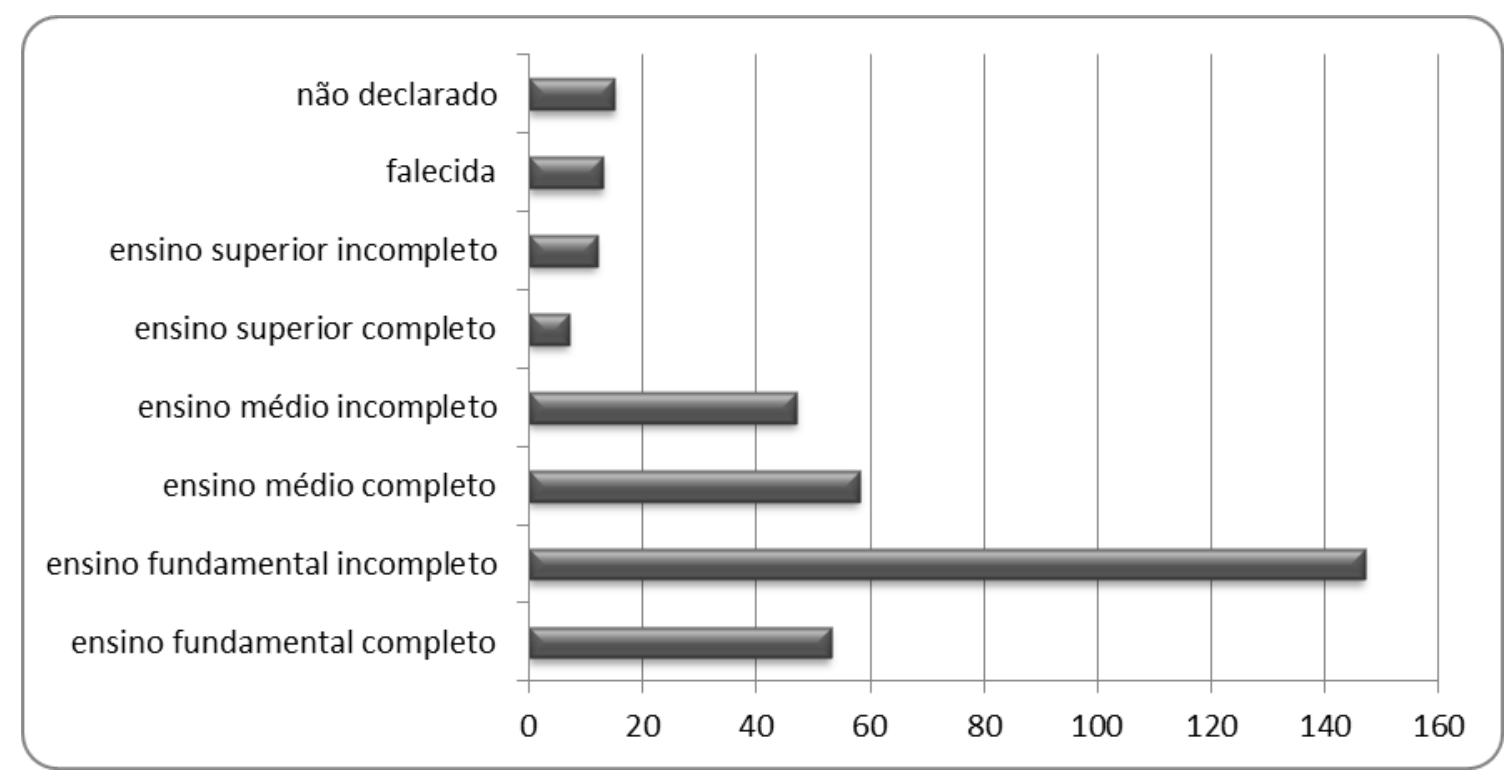

Fonte: Acervo MSU.

Figura 14 - Formação escolar do Pai conforme autodeclaração dos Sem Universidade, participantes do projeto de educação popular, do cursinho popular do MSU em 2003

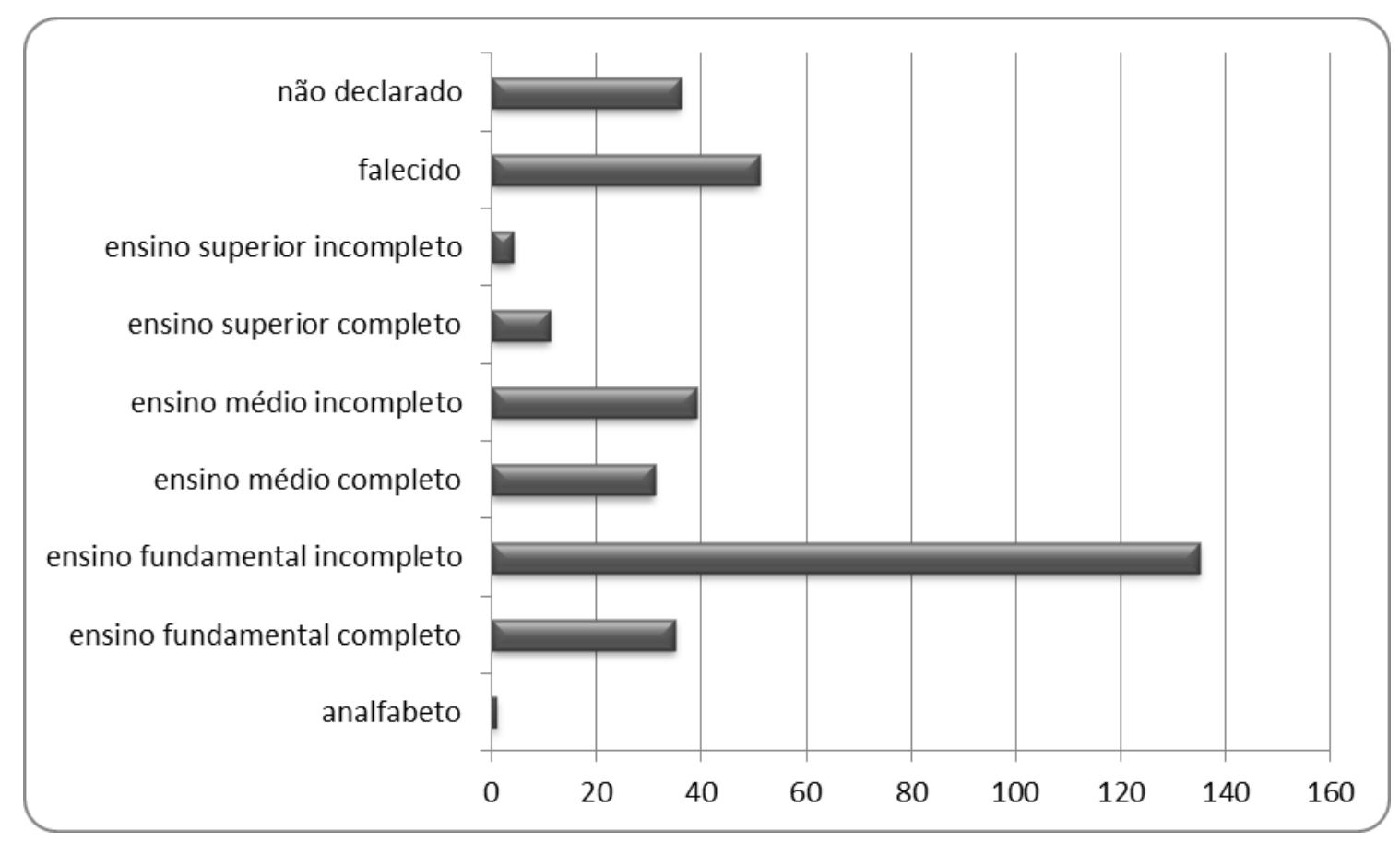

Fonte: Acervo MSU. 
Figura 15 - Hábito de estudo conforme autodeclaração dos Sem Universidade, participantes do projeto de educação popular, do cursinho popular do MSU em 2003

\section{Hábito de Estudo}

- assisto mais televisão do que estudo

— estudo pouco ou só estudo às vésperas das provas

च estudo quando tenho tempo, sem planejamento

- estudo regularmente até duas horas por dia, com planejamento

- estudo regularmente até quatro horas por dia, com planejamento

não declarado

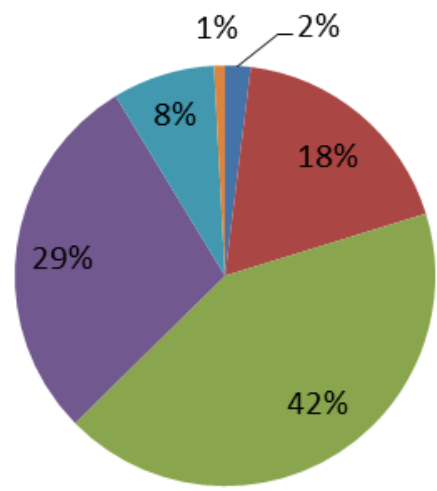

Fonte: Acervo MSU. 
Figura 16 - DISCURSOS OUTROS (último livro lido em 2003), conforme autodeclaração dos Sem Universidade participantes do projeto de educação popular, do cursinho popular do MSU em 2003

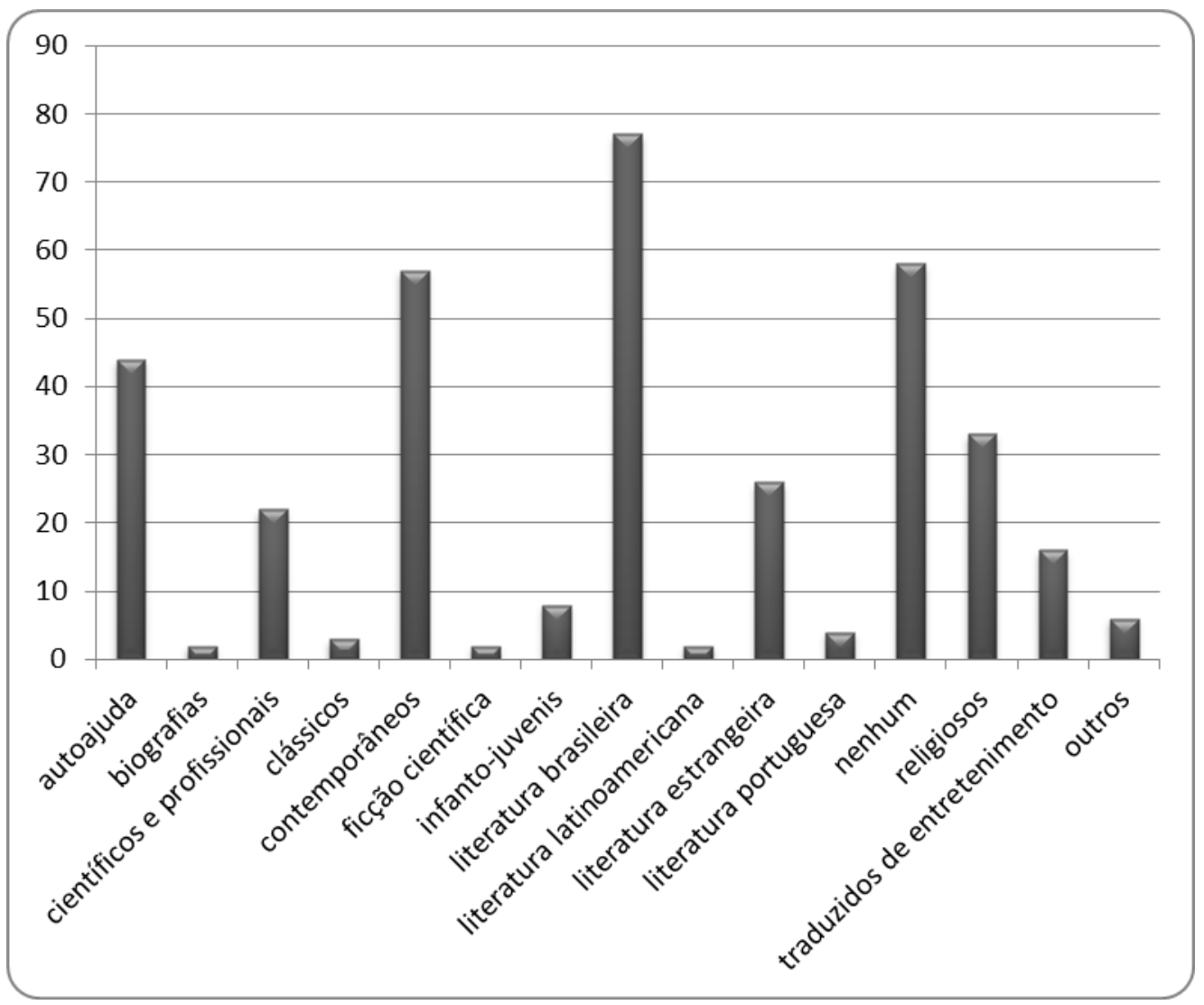

Fonte: Acervo MSU.

\subsubsection{Análise dos discursos presentes na mediação perceptiva indireta}

Na figura 7 aparecem 11 registros de cor/raça na autodeclaração dos agentes na totalidade do corpus, são eles: amarela, branca, escura, morena, morena clara, mulata, não declarado, negra, negra com orgulho, parda, preta.

Uma ausência chama a atenção: não há registro da presença indígena. Isso pode indicar que a probabilidade do discurso dos povos indígenas ser reivindicada no corpus é muito baixa, por um lado, por outro lado, a explicitação da condição indígena em São Paulo como uma minoria numérica, localizada em nichos geográficos específicos da cidade. Mas, no censo de 2000, visto no capítulo introdutório, essa presença se dá nas regiões que compõe o corpus, ainda que em franca minoria. A ausência total de indígenas no corpus nos leva então a uma hipótese: os indígenas em São Paulo, residentes nas áreas de abrangência do projeto de educação popular do MSU, não 
tinham em massa avançado ainda nos degraus da educação básica em 2003 a ponto de estarem às portas do ensino superior. Outra hipótese também se apresenta: a especificidade da cultura indígena e seu localismo, indicam que poderia existir indígenas em condição de ir para universidade em 2003 nas áreas específicas de maior densidade indígena da cidade, caso do bairro de Grajaú.

A presença branca é grande na periferia, o que indica que é real a presença do branco pobre na periferia em tela, por um ângulo, por outro que o branco pobre, por hipótese, teve mais condições sociais de progredir nos estudos do que o preto pobre, com baixo registro numérico no corpus, o que poderia indicar que o preto pobre não conseguiu avançar na velocidade desejada os degraus da educação básica até as portas da universidade. Comparando-se com o número de pretos que aparece na introdução, essa hipótese é forte.

A probabilidade da presença discursiva que considera a condição do branco pobre nos discursos dos agentes torna-se considerável.

Por seu turno, há indícios do discurso do embranquecimento, do mulatismo e da negritude já no momento da autodeclaração de cor/raça. Desconsiderando-se os não declarados, percebe-se que as autodeclarações feitas como morena, morena clara e mulata remetem em algum grau ao discurso do mulatismo. Como uma quantidade razoável de agentes assume essa autodeclaração, então, supõe-se a hipótese de que índices do discurso do mulatismo aparecerão nos discursos dos agentes.

De igual modo, quantidade razoável, assume a condição autodeclarada de negra, aparecendo também negra com orgulho, o que nos leva à hipótese de que o discurso da negritude terá guarida entre os discursos dos agentes.

Outra análise não pode escapar como indício: morena clara. O que, por hipótese, informa atitude típica da negociação da estratégia do discurso de "facilitar" a integração do negro na sociedade de classes brasileiras, reflexo da força discursiva do embranquecimento no imaginário popular, como assinalara Hofbauer (2006).

A presença da autodeclaração como mulata, morena e morena clara também remete ao discurso da democracia racial no Brasil, por hipótese, já incorporado nas identidades dos agentes, o que pode indicar os impasses da pressão discursiva dominante de Uns sobre Outros, o que poderia explicar também o número de não declarados. Essa situação poderá também reverberar nos discursos dos agentes.

$\mathrm{Na}$ figura 8 demonstra-se relativo equilíbrio entre o número de pretos e pardos versus o número de brancos, com vantagem pequena para os últimos, se retirarmos os 
não declarados. Essa situação indica a presença grande de brancos pobres no corpus. Por outro lado, por hipótese, podem indicar que brancos em condições financeiras melhores, que vivem nessas regiões, que tem heterogeneidades dentro dos territórios também gritantes, como é o caso de Itaquera (e não só), que guarda dentro dela áreas mais ricas convivendo com bolsões de pobreza em 2003, esses brancos mais ricos não teriam se interessado pelo projeto de educação popular do MSU, o que gerou o equilíbrio, em tese, da presença racial no projeto entre brancos e negros, pobres.

Esses dados, nessas localidades, por hipótese, demonstram também o grande interesse em frequentar o ensino superior no Brasil por parte de agentes negros. Esses dados praticamente equivalem àqueles do censo de 2000 da população dessas localidades como um todo. O corpo e sua cor contam na caminhada até a universidade.

A figura nove indica forte tendência de alteração na estrutura familiar, diga-se clássica, como a vista em Sader (1988). Há nítido deslocamento da centralidade da família nucleada em torno do pai-provedor, repercutindo as mudanças drásticas do mundo do trabalho e o quadro social duro do desemprego em 2003 no Brasil. Se somados aqueles casos de chefia de família que diferem do pai, o número é bem superior àqueles que indicam o pai como chefe familiar. Há grande destaque para a mãe como chefe de família e há número razoável de registros de que os próprios agentes são chefes de família, o que é índice de que o direito negado à universidade no Brasil percorre gerações e idades em 2003. Se por um lado, um número não declarado de mais de 100 agentes no tocante ao chefe familiar indicam variados arranjos familiares, por outro lado o fato de em torno de 100 agentes indicarem o pai como chefe, relativiza a noção de radical mudança na estrutura familiar. A presença da violência grande nesses locais, por hipótese, como se percebe pelo número razoável de pais falecidos, pode auxiliar na explicação das alterações da estrutura familiar. Fica evidente, por fim, um papel distinto da mulher, que provavelmente, avança para pelo menos dois turnos de jornada diária: em casa e fora de casa. O desemprego de 2003 atinge sobremaneira os homens, não sendo mais o provedor econômico do lar, da família, sua condição de autoridade também se desloca. Esses dados indicam, sobremaneira, a hipótese de uma multiplicidade de arranjos familiares, algo bem percebido em Feltran (2011), mas paradoxalmente, também o grande valor dado para a noção de família nas periferias, independente de quem esteja no timão. A fragmentação do mundo do trabalho que implica na fragmentação dos sujeitos, não tem jeito, por tabela, por hipótese, indica a dura realidade da fragmentação do discurso da classe trabalhadora na periferia em 
particular e na sociedade como um todo. Isso pode aparecer no discurso dos agentes. É clássica na literatura brasileira as marcações que subsomem a noção de raça, sob o manto da noção de classe. Com a noção de classe mais enfraquecida na base da sociedade, essa leitura tende também a perder força, até porque dividiria mais ainda a própria classe trabalhadora. É caso de verificar como isso aparecerá nos discursos dos agentes ou se não aparecerá. Sobretudo, o que o quadro de fragmentação da estrutura familiar do pai-provedor precipita de per si, é uma atomização das responsabilidades prematuramente nas famílias, o que pode indicar a labuta por emprego desde cedo, tanto para o homem, como para a mulher membro da família. Por exemplo, no quadro de desemprego de 2003, automaticamente implicava na epifania do trabalho informal, por qualquer trocado, não raro nas experiências de educação popular, nos cursinhos populares do MSU em estudo, pessoas andavam longas distâncias a pé, por falta de recursos, para chegarem na hora ao projeto, outras entregavam panfletos de propaganda imobiliária nas esquinas de São Paulo, enquanto sonhavam com a universidade distante. Essa atomização das responsabilidades no seio familiar pode, por hipótese, implicar numa responsabilidade discursiva mais explosiva dos agentes, isso pode aparecer nos discursos, porque muitos valores estão em jogo na decisão de ir para a universidade, é uma aposta na própria vida.

A figura 10 revela a força da participação das mulheres, majoritárias nos projetos de educação popular do MSU. Indica, por hipótese, o abandono do velho personagem que limita a mulher como "do lar", a busca por carreira profissional autônoma nos mais elevados níveis, o assumir de novos papéis sociais, sem ilusões com bruscas e intempestivas mudanças no quadro geral da condição da mulher na sociedade brasileira. Esses enfoques podem aparecer ou não nos discursos. Mas, é inegável a força da fala das mulheres nos discursos. Por hipótese, os discursos dos agentes podem revelar a fala da mulher negra da periferia.

Nas figura 11 e 12, escancara-se a predominância absoluta de oriundos da escola pública como ela é nos projetos de educação popular do MSU em tela. Isso vale uma pequena leitura crítica.

Vindos ou vivenciando a escola pública como ela é nessas regiões, não obstante, eles e elas são perturbados por discursos dominantes que inferiorizam a escola pública e superlativizam a escola privada, o que foi demonstrado no estudo de Filho (2005) para o período de meados dos 1990 até começo dos 2000, pertinente para o momento da 
produção textual, dos discursos presentes nos achados documentais, no corpus, é o que se verifica:

\begin{abstract}
ao contrário, uma vez estabelecida uma série documental, com a devida demarcação do período para a pesquisa, a lógica histórica, conforme define Thompson (1981) permite uma compreensão maior das disputas do campo educacional, mediante as quais se pode perceber melhor quem são os atores que escrevem artigos, bem como conhece sua trajetória acadêmica e as preferências recíprocas entre veículos de comunicação e o intelectual, além da autoridade que o domínio da língua legítima garante para a publicação de uma notícia que, a rigor, se desdobra em dois níveis de legitimidade. 1) a notícia que se pretende legítima, por diversas razões políticas e preferências pedagógicas dos proprietários e sua linha editorial, e o próprio intelectual, que garante capital específico no campo jornalístico e que será utilizado nas disputas no campo educacional; 2) o outro nível está na própria legitimidade que os atores constroem, mesmo quando estão diretamente ligados à burocracia estatal, para seus projetos de hegemonia no campo educacional. Assim, as notícias sobre educação na imprensa, de acordo com a pesquisa, representam uma interface de prescrições pedagógicas que, reciprocamente, produziram o conceito da boa escola no campo educacional brasileiro na segunda metade da década de 1990 (FILHO, 2005, p. 217).
\end{abstract}

Repetido a mais não poder, esse "consenso" forjado na cozinha da grande mídia brasileira, entre os chefes editoriais dos seus setores principais, concentrados e com grande poder de fogo discursivo pela fatia de mercado que controlam, exala verdades: a eficácia dos gastos públicos, a educação para a empregabilidade, a organização do mercado de educação, os rankings educacionais. Como demonstra o autor, não é apenas "o discurso conservador de Veja", mas uma trama discursiva, uma rede de legitimidade que elege o que é a boa escola. O ensino médio técnico restrito e apartado do propedêutico, a progressão automática, os cursos superiores de curta duração etc. Isso, por hipótese, irá perpassas sobremaneira o fazer discursivo dos agentes. No discurso da boa escola "some-se" com a questão racial. Também pudera?

Nesse passo, do lado dos agentes, é notória a vivência pessoal de muitas situações, como a falta de professores em muitas disciplinas do ensino médio público, a falta de material didático, laboratórios, as condições de trabalho dos professores, dentre outras mazelas, o que pode dar mais corda ao discurso da "boa escola" ou por os pingos nos is e na luta em defesa de um sistema público nacional de educação com qualidade nos meandros dos discursos dos agentes, ou não também.

As tatuagens do discurso neoliberal em educação, entretanto, têm vários matizes nas paisagens e nos corpos, feito estacas fincadas que abrem mercados em chão bruto, como os bandeirantes fizeram outrora na busca do ouro.

A nova invasão dos territórios é um ladrilhar feito a muitas mãos, trata-se de novos negócios educacionais nos municípios, nas periferias, como alternativas privadas 
ao ensino público disponíveis logo ali nas esquinas das periferias, da creche á pósgraduação ou como intersecções publico e privado, nos interstícios do ambiente público da própria escola pública e nas tabelas de ganhos dos agentes duplos organicamente inseridos, como indica o Documento 132:

\begin{abstract}
Porque, em muitos casos o problema do aluno não aprender, não ter vontade de estudar, não se interessar por nada. Não vem dele próprio, as vezes o ambiente onde ele vive, não o motiva ou na maioria dos casos a escola onde ele estuda e os professores que nela dão aula, não dão o ânimo necessário que o aluno por direito deve ter e eles não incentivam como devião. Eu falo isso, porque eu sei, aconteceu comigo e acontece com amigos meus. No meu bairro a maioria das escolas públicas, é muito precária a situação e os professores muitas vezes faltam e se não faltam não explicam muito bem as matérias dadas. Porque esses professores dão aulas em três ou quatro escolas boas (particulares) e vem passear nas escolas públicas da periferia (que é o meu caso). “(D 132, Anexos, 18 a 29).
\end{abstract}

A educação básica organizada como mercado, como serviço de variados preços nas prateleiras dos consumidores de educação privada virou febre e ganhou corações e mentes no Brasil no cio da tempestade neoliberal dos anos 1990. Isso espalhou-se como pequenos negócios localizados, pequenas cooperativas de professores ou franquias, seja em áreas interioranas, seja nas grandes periferias urbanas massivamente habitadas.

Em muitos casos, a escola pública se viu reduzida à condição de fornecedora de clientela estudantil para esses negócios, e os mercadores, sem pudor nenhum, em muitos casos habitavam o ambiente da escola pública nas mais variadas posições internas como aqueles agentes duplos de filmes de espionagem, para, desde essa base, como agentes que eram desse organismo, organizar a demanda efetiva e alavancar seus negócios e sócios da empreitada privada para fora da escola pública, porém desde o ambiente interno da própria escola pública, em vizinhança não muito distante, pois logisticamente mais lucrativa e muitas vezes mantendo os vários ganhos.

Por tabela, uma nova diferenciação social se processa, por efeito demonstração, onde a cizânia do ethos da escola pública, ainda não plenamente potencializada em sua qualidade, implicou na cessão de um lugar à mimetização do comportamento da classe média tradicional brasileira por moradores de bairros populosos e populares, por parcela de seus habitantes seduzidas pelo ethos da escola privada típica da classe média tradicional brasileira: o uniforme, a marca, o material didático de um grande sistema de ensino privado, o carnê, a mensalidade, a "diferenciação social" na margem e as promessas do marketing. 
Seria o equivalente a um novo status divisor de águas em territórios populares enfraquecendo a postulação da universalidade da educação básica pública de qualidade nas famílias populares.

A base social do neoliberalismo no Brasil, desse modo, não é nada desprezível, pois ampliou sua adesão fortemente entre os corações e as mentes por processo consorciado e lucrativo de envolvimento da base social, inclusive no meio popular, onde alguns professores de escola pública, dentre outros agentes desse meio, vestiram a carapuça do discurso do empreendedorismo para agigantar os salários baixos da regra da escola pública, dentre outros consórcios afins.

O orçamento real das famílias potenciais clientes era a barreira da realidade, perpassada com mil e um esquemas e estratagemas de negócios educacionais para fidelizar clientelas sedentas de distinção a qualquer custo, muitas vezes destoantes do padrão de qualidade de imitação da norma da classe média branca e rica tradicional..

Se os novos donos de escolas privadas dos anos 1990 estavam nas revistas, nas tramas discursivas dominantes, nas novelas de televisão, também estavam nas práticas reais de corrida pelo dinheiro a qualquer custo no metier da educação privada e suas urdiduras nas terras das grandes periferias urbanas ou nas áreas interioranas, antes lugares somente de escolas públicas tradicionais, em muitos casos.

Ora, isso não pode ser considerado algo neófito na história da educação nacional, mas sim extremamente coerente com os episódios de dentro do sistema nacional de educação nos séculos XIX e XX, onde o ensino particular sempre teve cadeira cativa, basta lembrar que de 1824 a 1930 o Brasil já funcionou com Estado Mínimo, sem Ministério da Educação dentre os sete que acomodavam os mandarins regionais em concumbinato pelo domínio do Estado, para o melhor e mais sábio desprezo pelos analfabetizados, os sem-universidade e o edifício não erguido da educação pública nacional de qualidade em todos os níveis para a população.

Outro ingrediente corrosivo sobre o fazer discursivo dos agentes e que opera como mediador perceptivo indireto é o discurso da propaganda: a que há e a que não há.

Na televisão que invade os lares no mundo de 2003, onde ainda detinha mais de cinquenta por cento de audiência nos lares paulistanos à noite, há a propaganda do ensino superior privado, tonitruante, quase que de uma nota só: "eu coloco você no mercado de trabalho". Ausente dos lares está a propagada das universidades públicas. Quase $80 \%$ das ofertas das vagas no ensino superior da capital paulista são privadas em 2003. O habitus da educação superior pública como direito tem que enfrentar as 
metáforas do discurso da propaganda. Será que isso reverberará nos discursos dos agentes?

Nos casos das figuras 13 e 14 a mediação perceptiva indireta se dá por herança, pela posse do capital cultural dominado no cotidiano do lar. Em Custódio (1999) é nítido o peso na balança da injustiça no acesso à universidade pública estadual de Campinas, pois aqueles dados demonstravam que os aprovados na Unicamp, majoritariamente, nos anos 1990, tinham os país com ensino superior completo.

Os dados demonstram nessas figuras, que a realidade é outra, praticamente dez anos depois, ou mui provavelmente continua sendo outra nas periferias paulistanas. Os pais dos homens e mulheres Sem Universidade não frequentaram a universidade, salvo exceções, mesmo o ensino médio, poucos concluíram. Isso, conforme os estudos de Bourdieu, Lahire, Silva, dentre outros, impacta no domínio do capital cultural apropriado pelos agentes, em uma dimensão negativa, favorecendo o status quo.

Essa realidade talvez impulsione, por hipótese, a responsabilidade discursiva dos agentes, pois praticamente são os primeiros, as primeiras, a encararem o bicho de sete cabeças do direito à universidade no Brasil de frente. Outra hipótese é que, o fato de isso implicar num esforço individual hercúleo, uma relativa humildade no comportamento individual, em que pese a brutal competição por um emprego no começo doa anos neoliberais do novo milênio no Brasil, isso possa sim sinalizar a necessidade de saídas coletivas, que a todos e todas, nas mesmas situações históricas acudam, atendam, seja para tornar mais leve o fardo individual sobre as costas, seja para obter resultados efetivos mais rápidos. Nesse sentido, isso pode fazer aflorar discursos cujo ethos é coletivo ou empurra para discursos coletivos, sujeitos coletivos, pois a busca por um habitus novo é evidente para eles e elas, no sentido da incorporação dos estudos na vida, no corpo, para manter a vida ou a sobrevivência, para colocar os corpos em novos patamares sociais, numa lufa-lufa por ascensão social pela via dos estudos.

Essas figuras também indicam, pelo próprio fato de muitas pessoas baterem as portas das universidades, uma ultrapassagem relativa sobre os anos de estudos dos país, o que de per si, também por hipótese, pode encorajar os agentes a assumirem mais riscos discursivos.

Na figura seguinte, emerge como hábito (atenção, não é habitus) uma relação frouxa com os estudos por parte da maioria, ao passo que há uma massa crítica mínima, mais relevante, com uma relação forte com os estudos. Isso indica o efeito do curto prazo sobre a vida na periferia em 2003. O fato de não existir condições sociais 
objetivas oferecidas pelo cotidiano das periferias nas regiões em estudo, indica, por hipótese, um governo da vida pela pressão do curto prazo, o que faz evaporar perspectivas mais generosas com a própria vida, como o planejamento de médio e longo prazo, o que no caso da caminhada até a universidade pública, por hipótese, abrigaria terreno para incluir estudos de pós-graduação, doutorado, enfim, carreiras que, automaticamente, imporiam uma regulação e organização meticulosa do tempo de estudo, numa semeadura para colheita futura.

Não é desprezível, reforce-se, a massa crítica que os dados indicam que adotam hábitos regulares de estudo, tem essa prática no cotidiano. Por hipótese, dessa gente pode emergir discursos com responsabilidade discursiva entoadas de maior lastro histórico, para trás e para frente, porque o estudar é embebido de um conceito, de uma meta objetivada nos dias, traduzida em trabalho intelectual cotidiano, o que enfrenta o mito de que o pobre, os negro, a periferia, "não nasceu para mandar". Por hipótese, esse grupo pode servir como ponta de lança discursiva nessa direção, já nos seus discursos no corpus.

Por fim, o item abordado na figura 16, as leituras feitas e os discursos que elas ensejam e que, indiretamente, atuam como ativas mediações perceptivas indiretas no fazer discursivo dos agentes, indicam rumos paradoxais: 1) o desprezo à leitura, com registro razoável entre os agentes; 2) a forte presença da literatura brasileira liderando o cardápio de livros lidos. Esse paradoxo fatalmente aparecerá, essa é uma hipótese muito forte, nos discursos dos agentes.

Há também a força do discurso de autoajuda, do discurso religioso e de livros contemporâneos e de entretenimento traduzidos.

Em 2003 o livro é muito caro no Brasil, um produto de luxo, em particular nas periferias. Logo, mesmo a indicação de nenhum livro lido no último ano, pode não significar que não se teve acesso a livros. Fato é que o hiato entre os homens, as mulheres e os livros tem muita força dentre os agentes.

Mas não é verdade mesmo que a periferia não lê, estão lá citados.

Isso não deixa de ser uma nota discursiva salutar e que revela o peso do avanço da organização do sistema de educação no Brasil no começo dos anos 2000, pois parte dos agentes leem, dentre outros autores/autoras: Homero, Clarice Lispector, Lima Barreto, Machado de Assis, Edgar Allan Poe, Aluízio Azevedo, Graciliano Ramos, Eça de Queiroz, Gustav Flaubert, Gabriel Garcia Marques, Érico Veríssimo, Vinícius de Morais, Jorge Amado, Euclides da Cunha. 
Já o discurso da não leitura, dos que nada leram em 2003, pode revelar a reprodução histórica da partição dos mundos: o mundo dos estudos e o mundo do trabalho, onde há um divórcio entre esses universos, senha dos discursos dominantes de Uns sobre Outro com grande peso na continuação da reprodução histórica da desigualdade social e racial no Brasil, o que pode aparecer nos discursos dos agentes.

No tocante aos discursos religiosos e aos queijos da autoajuda, essas visões, por hipótese, aparecerão nos textos, e, tendem a aparecer com força discursiva, porque elas carregam muito sentido e poder no cotidiano das periferias, dada a árdua luta pela sobrevivência e o peso da cultura religiosa nas periferias, em suas casas, nas famílias, em particular a cultura crista, num quadro de declínio da força do catolicismo no Brasil e de ascensão das religiões evangélicas, com destaque para as neopentecostais. É nítido, de qualquer forma, na literatura religiosa, a ausência das principais referencias que compunham a teologia da libertação na América Latina, índice do conservadorismo do discurso de Roma em 2003. Esses referenciais impulsionaram o surgimento dos novos movimentos sociais, como no relato de Sader (1988).

Mais uma ausência nos livros citados chama a atenção, elas são várias, uma em particular faz coro com a fragmentação do mundo do trabalho: a ausência da literatura de matriz socialista, da forte tradição socialista no meio popular. Isso, por hipótese, aparecerá nos textos dos agentes, em seus discursos, digo a ausência.

\subsection{A mediação epistêmica complementar}

Muitas vezes, uma presença discursiva irrompe onde menos se espera. Por isso, um gênero do discurso não pode ser tomado estritamente como uma caixinha fechada, pois ele pode ter porosidades, complementos fora dele. Assim, ainda que o centro da análise do discurso nesse estudo caia sobre o gênero do discurso redação, existe a presença da avaliação do conhecimento também em partes menores do documento, do corpus. O paradigma indiciário, presente na lavoura teórica dessa pesquisa, por si só autoriza investidas que possibilitam, virtualmente, aumentar o entendimento da riqueza documental, da plenitude discursiva através da busca por eventuais rastros discursivos, 
ou detalhes discursivos perdidos num documento escrito. As questões ampliam a cena discursiva, robustecendo a análise do discurso.

É o caso das respostas escritas a duas questões dissertativas dentre as 12 questões que compõem o documento, o corpus.

As questões, tomadas como mediações epistêmicas complementares, remetem a cultura popular brasileira. Por que são complementares. Porque trazem o ethos popular mais evidente e explicitam fortemente o debate ensejado na literatura teórica que é o combustível desse estudo: o discurso, ganha sentido, no cotidiano. É complementar porque diretamente tratam, uma da questão racial, outra do cotidiano da periferia.

Um traz o cancioneiro brasileiro e um autor de referência na perspectiva englobada pelo discurso da negritude, outro um exemplo dos novos cronistas urbanos, que ecoam as vozes e o cotidiano da periferia, onde se assentam os documentos, os discursos dos agentes e os próprios agentes históricos. Por isso, por hipótese essa mediação epistêmica complementar aumenta a aderência da relação discursiva com o espaço discursivo.

Segundo Motta (2011), “o autor (referindo-se a Maingueneau) adverte que 'não fazer parte da lógica de um gênero do discurso' não quer dizer que os enunciados aforizados estejam fora do discurso, pois não existe enunciação fora dos gêneros" e conclui:

\footnotetext{
fortalecer o eu-coletivizado passa por enunciar de modo sentencioso, representando seus enunciados como um "como dizem". E esse funcionamento nos Racionais MCs, vai além de utilização ou citação de formas linguísticas fixas, constituindo um verdadeiro funcionamento discursivo aforizante (MOTTA, 2011, p. 172).
}

Com Florestan Fernandes, Milton Nascimento e Racionais MCs, negros entram para a cena discursiva desse estudo, o que ganha conotação não apenas epistêmica complementar, com berço na academia e na cultura popular brasileira simultaneamente, mas enriquece sobremaneira o trabalho do analista do discurso, ao alargar o horizonte analítico. Se Pêcheux apontava o cotidiano como a garagem dos sentidos discursivos, dos discursos, bom trazê-los em sua densidade e força por intermédio dos cronistas da periferia, do cancioneiro popular cuja letra da música atravessa a história negra no Brasil, e do estudioso crítico filho de empregada doméstica e que nomeia a Comissão de Educação da Câmara dos Deputados do Brasil.

Vejamos:

Questão 1) "O padrão brasileiro de relação racial, ainda hoje dominante, foi construído para uma sociedade escravista, ou seja, para manter o negro sob 
sujeição do branco. Enquanto esse padrão de relação racial não for abolido, a distância econômica, social e política entre o negro e o branco será grande, embora tal coisa não seja reconhecida de modo aberto, honesto e explícito". Trecho extraído do livro "O negro no mundo dos brancos", de Florestan Fernandes.

"Negra voz de velha só

Numa igreja interior

Me falando do seu tempo

Conta a idade, conta o que restou

Onde os filhos que eu criei?

Vida presa no quintal

Me lembrando desse tempo

Vejo quem vem meu leito festejar

Três meninos nascendo do ventre negro, sem cor

Meninos sentados no chão

Quem veio por eles buscar?

Hoje eu digo 83

Sem diamante, escravidão

Nem pergunto pelos filhos

Ligo o rádio, durmo no colchão"

Maria Três Filhos, de Milton Nascimento e Fernando Brant.

Com base no que você leu no trecho do livro acima, na letra da canção e no seu conhecimento, aponte elementos que ilustre a situação do negro na sociedade brasileira atual?

Questão 5) Leia a letra da música "Mano na porta do Bar":

"Você viu aquele mano na porta do bar,

Ultimamente andei ouvindo reclamar

Que a sua falta de dinheiro era problema,

Que a sua vida pacata já não vale a pena,

Queria ter um carro confortável,

Queria ser um cara mais cotado.

Tudo bem até ai nada posso dizer,

Um cara de destaque também quero ser (...)

A lei da selva, consumir é necessário;

Compre mais, compre mais,

Supere seu adversário.

O seu status depende da tragédia de alguém.

É isso capitalismo selvagem.”

Racionais MC's

Relacione a letra da música a um aspecto do cotidiano da periferia urbana das metrópoles brasileiras. Discorra brevemente sobre este aspecto. 


\title{
5.5. As quebradas discursivas
}

Foi selecionado um conjunto de documentos significativos, nome que ganham aqui os textos, o que merece a devida centralidade, como apontado por GERALDI [1991] (2013),

\begin{abstract}
Considero a produção de textos (orais e escritos) como ponto de partida (e ponto de chegada) de todo o processo de ensino/aprendizagem da língua. $\mathrm{E}$ isto não apenas por inspiração ideológica de devolução do direito à palavra às classes despriviligiadas, para delas ouvirmos a história, contida e não contada, da grande maioria que hoje ocupa os bancos escolares. Sobretudo, é porque no texto que a língua - objeto de estudos - se revela em sua totalidade quer enquanto conjunto de formas e de seu reaparecimento, quer enquanto discurso que remete a uma relação intersubjetiva constituída no próprio processo de enunciação marcada pela temporalidade e suas dimensões. (p. 135).
\end{abstract}

Do corpus, constituído por 360 documentos no gênero do discurso avaliação de conhecimento, limitado aqui por uma redação e duas questões dissertativas, os documentos ganham o nome D e o respectivo número, conformando uma amostra, como se apresenta em anexo na íntegra, selecionada com base nos critérios de melhor adesão emblemática aos discursos do espaço discursivo e pelo critério de valor ilocucionário relativo (conf. polo $\mathrm{C}$ do esquema de Adam adaptado, ver figura 2) .

Para a análise dos discursos da amostra selecionada, um primeiro passo foi sua organização por núcleos discursivos por polos de afinidade com os discursos do espaço discursivo em função da robustez dos locutores na enunciação com responsabilidade.

Tabela 4 - Núcleos discursivos vis-à-vis a amostra analítica eleita

\begin{tabular}{|l|l|l|l|l|}
\hline ND1 & ND2 ND3 & ND4 & ND5 \\
\hline
\end{tabular}




\begin{tabular}{|l|l|l|l|l|}
\hline D 93, D 13 & D 282, D 121 & D 212 & D 29, D 165, & D 262, D286 \\
\hline D 23, D 41 & D 37, D 17 & & D 299, D 283, & \\
\hline D 40, D 175 & D 20, D 199 & & D 261, D 114, & \\
\hline D 143, D 319 & D 193. D 149 & & D 78, D 2, & \\
\hline D 119, D 212 & D 222, D 162 & & D 90, D 152 & \\
\hline D 112, D 123 & D 132, D 87 & & D 120, D 117 & \\
\hline D 313 & D 202, D 185 & & D 124, D 130 & \\
\hline & D 111, D 243 & & D 210, D 184 & \\
\hline & D 34, D 289 & & D 335, D 262 & \\
\hline & D 260 & & D 235, D 191 & \\
\hline & & & D75, D 348 & \\
\hline & & & D 169, D 85 & \\
\hline & & & D 131, D 200 & \\
\hline & & & D 179, D 201 & \\
\hline & & & D 16 & \\
\hline & & & & \\
\hline
\end{tabular}

ND1: Núcleo Discursivo relativo ao discurso do embranquecimento; ND2: Núcleo Discursivo relativo ao discurso do mulatismo; ND3: Núcleo Discursivo relativo ao discurso do indianismo; ND4: Núcleo Discursivo relativo ao discurso da negritude; ND5: Núcleo Discursivo relativo ao discurso dos povos indígenas.

Em seguida, para cada núcleo discursivo, têm-se a análise conjunta dos discursos a partir de enunciações consideradas mais emblemáticas e um ponto nodal de cada núcleo discursivo é eleito para análise in totum. É o que segue.

\subsubsection{A presença discursiva do discurso do embranquecimento (ND1)}

Enunciados presentes em D123:

R: "Quanto ao tema cota para negros, não concordo da forma que é apresentado, é claro que são maioria, mas não são os únicos excluídos, existem brancos que 
também são carentes. Acredito que ações como essas, que tendem a favorecer só um determinado grupo só vão trazer dor de cabeça e mais discriminação. $O$ correto, seria expandir a ideia para todos os tipos de carentes, sejam eles negros ou brancos, segundo não ser aplicado na metade das cotas e sim como um critério de diferenciação. Por exemplo no caso do empate na pontuação do vestibular, nesse caso teria a vantagem quem for carente, pois se continuar na metade atual de cotas, com toda a certeza a qualidade do ensino vai cair e em certos casos será apenas mais um com diploma nas mãos e não um profissional formado." (1 5 a 28).

\section{Q1: Não respondeu.}

Q5: "Lamentavelmente isso que foi dito é uma verdade e muitas vezes mesmo pra quem trabalha é difícil conviver com um fato inegável, a "moda" não digo somente em termos de roupa, mas em geral, faz com que nos sentimos menos pessoas, quando não podemos comprar um tênis ou uma roupa de marca por exemplo. É muito difícil conviver com situações como essas, e isso acontece em vários sentidos, hoje algo pior está acontecendo, e isto é, a exigência de um corpo belo cada vez mais."

\section{Enunciados presentes em D93:}

R: "Outra medida para tornar mais "justo" o vestibular, seria o sistema de cotas, que garante uma determinada quantidade de vagas para negros $e$ afrodescendentes, que a meu ver é uma medida ineficaz e preconceituosa, já que poderia garantir o acesso de pessoas que possam não estar qualificadas e também não podemos dizer "fulano é o melhor aluno negro" e "Beltrano é o melhor aluno branco", acho que não é bem esse o caminho.

Agora a medida que me parece mais eficaz, seria a criação de curso pré-

Vestibulares gratuitos e à ampliação do ensino médio para quatro anos, este último ano Seria preparatório para o vestibular. “(131 a 47).

\section{Q1: Não respondeu.}

Q5: "No trecho apresentado vemos uma pessoa que reclama a falta de dinheiro e pensa que só pode ser aceito na sociedade se tiver "grana", e que não importa a forma de que forma vai conseguir essa "grana"."

Enunciados presentes em D13:

R: "Concordo com Eunice Durham Texto 4. 
Quando ela diz que acha errado o sistema de cotas, e que devemos melhorar antes de Ingressar na faculdade." (1 1 a 5).

Por isso que concordo que temos que melhorar antes de ingressar na faculdade ela deu uma grande ideia como criar cursos pré-vestibulares gratuitos, dessa forma estará Preparando o jovem e capacitando ele a ingressar em uma universidade sem que ele

fique perdido e venha a perder a vaga." (1 14 a 21$)$.

Q1: "Muitos criticão os negros e achão que se sobreçaem sobre eles. Por eles terem sido escravos e que só prestam para servir os outros.

Até mesmo nas nossas emissoras de televisão quando aparece um negro, é empregada doméstica.

Temos que começar a mudar por aí que é onde o brasileiro mais se concentra senão não vamos mudar nas ruas."

Q5: "Que por não fazer, que seu meio de vida mudasse ter vivido sempre na mesma rotina, começa a desanimar e só passa a reclamar da vida."

Enunciados presentes em D23:

R: “A condição de criar cotas para negros são desfavoráveis, pois “- Não é a cor da pele que diz se você é inteligente ou burro" e sim a classe social que pode influenciar em seu desenvolvimento.

Q1: "Elemento: Abolição + a distância econômica, social e política".

Q5: "A DIFICULDADE p/ uma pessoa de baixa renda faz com que ela "sonhe" com o consumismo e queira ter tudo bom bom e do melhor como não tem qualificação na maioria das vezes parte para a marginalidade (“o dinheiro Facil”)."

Enunciados presentes em D41:

R: "As cotas deveriam existir para esses casos:

Alunos que estudaram a vida toda em Escola Pública ou Municipais, e que comprovassem baixa-renda.

Porque se você cria cotas para negro ou afro-descendente, daqui a algum tempo terá de criar para japonês, judeu, italiano e assim por diante." (1 a 23).

Q1: “O negro na verdade ele ainda não é livre. Mas o preconceito maior as vezes é ele quem coloca. Exemplo:

Quando dizemos aquele negro é bonito. 
Ele diz: negro não. Moreno.

Quando acabarmos com esse preconceito de o negro ser submisso, e o próprio parar de se discriminar talvez viveremos melhor."

Q5: "Bom a letra diz que aquela pessoa que fica em frente o bar vendo as outras pessoas passar, vê uma que cresceu e deu certo, outra com um bom emprego, e consegue comprar tudo o que quer.

Ele fica desesperado porque tem que consumir e não há dinheiro nem emprego para isso."

Enunciados presentes em D40:

R: "Podem dizer que se trata de racismo ou até mesmo exclusão social mas não se trata disso. Vão continuar discutindo enquanto não perceberem que estão errados em relação a tudo o que dizem e que não é necessário cotas, é preciso melhorar o ensino público, porque acredito que o fato de estar separando vaga por etnia, situação financeira ou social já soa como discriminação pois se não é para haver discerssão de pessoas a questão não está no tanto de vagas que uma universidade mantém separada para pobres e negros e sim na preparação que estes tiveram para competir de igual para igual independente de sua situação social ou financeira." (1 9 a 27).

Q1: “Apesar de ainda hoje haver "pessoas que discriminam as raças, o negro hoje é bem aceito na sociedade. Acredito que a diferença de antes para agora é que a discriminação está sendo abolida das ruas, mas ainda continua dentro de muitos, e só reparar em algumas "piadas"."

Q5: “Os "jovens” de hoje se enquadram na posição em que esta musica coloca. Porque para não serem excluídos do grupo, compram e fazem qualquer coisa para comprar "artigos" que os fazem parecer incluídos nos grupos. A ideologia que eles "recebem" e "interpretam" como se fossemos "bonecos" e que devemos seguir e fazer tudo igual aos outros."

Enunciados presentes em D119:

R: "É inegável que o sistema de Educação no Brasil está mudando. Mas será que está mudando para melhor? Vários projetos estão sendo feitos, mas até agora os estudantes não sentiram nenhuma mudança significativa." (1 3 a 5).

Um ponto bem polêmico dessas mudanças na Educação no país é o tão comentado sistema de cotas para os negros, mostrando que ainda há um preconceito 
muito grande na sociedade brasileira.Se de um lado, o sistema dá uma possibilidade de cada vez mais negros ingressarem nas camadas nobres da sociedade, por outro lado, deixa explícito um verdadeiro racismo enrustido, pois discrimina os negros de uma forma deliberada, e os criadores da cota inventam a desculpa esfarrapada de que os negros devem ingressar na universidade por uma questão de mérito. Mérito? As vagas já estão reservadas para eles. (1 27 a 35).

Q1: "Poderia citar várias situações, mas uma bem marcante e que causou bastante comentários há pouco tempo atrás foi o fato das universidades darem cotas de suas vagas para estudantes negros, mostrando que ainda há um preconceito muito grande na sociedade brasileira, pois no meu modo de ver dar uma cota específica para estudantes negros é um racismo enrustido".

Q5: “A guerra urbana que foi destaque nos jornais nos últimos dias, em especial, na Linha Amarela, no Rio de Janeiro, onde traficantes luta contra a polícia como se estivessem num filme de faroeste, e a rota do tráfico de drogas fica cada vez mais poderosa, fazendo bandidos como Fernandinho Beira-Mar e Elias Maluco terem status de popstars, deixando bem claro o comando paralelo que existe no país, com sua periferia, infelizmente, idolatrando marginais que espalham o caos, a morte e a desgraça onde dominam. Acorda, Polícia!!!”

Enunciados presentes em D212:

R: "Não sou a favor de cotas na universidade, acho que com um ensino melhor, mai dinâmico a gente cortaria o mal pela raiz. Mas também não discordo, é uma maneira deles estarem lutando pelos seus direitos porque do jeito que está não dá pra ficar, só rico fazendo universidade e mandando no nosso país.

As cotas para mim cria um certo racismo não só para com os negros mas também com os indígenas os nordestinos porque não é só negro que é pobre e estuda em escola pública. Sendo assim as cotas nas universidades deveria ser parquem ganha um salário ou nenhum, deveria ser avaliado a sua vida sócio-econômica. E só entrar em faculdade pública gente pobre como o poder aquisitivo menor."

Q1: "Desempregado, sem moradia e analfabeto."

Q5: "Na periferia as nossas crianças dão valor a quem tem carro, roupas de grife e é repetido como os traficantes e se espelham neles. Porque seus pais que trabalham mal conseguem dar les o que comer." 
Enunciados presentes em D175:

R: "Ao ivez de ter cotas deveriam melhorar o ensino para que todos podesem entrar na Universidade sem ter a tal da Cota, que é injusta porque se um negro presta vestibular para um determinado curso e faz 60 ponto a outra pessoa declarada Branca faz a mesma prova declarada e tira 90 e não passa por isso é injusto, sou negro totalmente contra cotas.

Enquanto não melhorarem o nosso ensino as universidades privadas vão ficar cada vez mais rica e favorecendo a elite desse país." (125 a 39).

Q1: "Meninos sentados no chão, os meninos não perspequitivas de vida nenhuma para o futuro".

Q5: "Muitos tem tudo na vida e outros não. A falta de dinheiro, o desemprego faz com que as pessoas fiquem desesperadas."

Enunciados presentes em D143:

R: "Eu, particularmente, não concordo com esse esquema de cotas e nem com o fato de a pessoa adquirir alguns pontinhos por causa de sua colocação no E.N.E.M.

O racismo existe; está diante de nossos olhos, e nós não o vemos (ou fingimos não vê-lo).

Por que eu devo ter cota numa universidade só porque sou negra? Os cidadãos não são iguais? Os direitos não são iguais?

Então, ou todos têm privilégios, ou ninguém tem."

Q1: “O negro hoje (como sempre), é bastante discriminado. Só que isso não é mostrado como antigamente. É só olharmos em nossa volta e veremos que quase nenhum negro ocupa cargos de chefia, "nas universidades brasileiras apenas $2 \%$ dos alunos são negros"; na televisão brasileira os negros são minoria e os lugares onde mais se tem negros é na mão-de-obra pesada nas empresas. A partir disso, acredito que nasceu negro, sofrimento em dobro."

Q5: “As pessoas da periferia têm menor poder aquisitivo, isso não é surpresa pra ninguém; porém, vivem num país capitalista, onde quanto mais se tem, mais se quer. Então com certeza essas pessoas não tem condições de consumir tudo que desejam e acabam reclamando de tudo." 


\subsubsection{O caso nodal D119 e outros exemplos: fortes indícios da presença viva do discurso do embranquecimento na amostra}

Os discursos vistos acorrem, acomodam-se, guardam relação, são satélites do polo discursivo do embranquecimento, logo, desse núcleo discursivo. Há uma relação de pertencimento discursivo. É temerária uma busca de identidade discursiva total. Mas, é inquestionável que os locutores defendem seus pontos de vista com responsabilidade e as identidades dos discursos selecionados "coincidem com a rede de interincompreensão na qual ele é capturado" (Maingueneau, 2008, p. 22), isso vale isoladamente para cada discurso acima.

Esses discursos vistos, entram no jogo interdiscursivo e, ao fazê-lo, levam em conta "que há uma considerável margem de "jogo"” (Maingueneau, 2008, p. 22) no interior do discurso do embranquecimento e no espaço discursivo em que ele se insere, nessa rede semântica de interincompreensão polêmica.

Para tanto, não se cobra aqui um novelo discursivo complexamente trançado de um discurso ideal do embranquecimento de onde fios ideais discursivos se enovelam linearmente, mas "podemos muito bem supor que a relação constitutiva é marcada por poucos índices na superfície discursiva" (Maingueneau, 2008, p. 35).

Os discursos falam para/de grandes camadas da população brasileira, esses são os perfis dos discursos e os enunciadores decididamente entraram em campo para o jogo discursivo. Por zelo analítico, é suficiente a menor unidade, pois

\footnotetext{
A menor unidade discursiva supõe o acionamento do conjunto do sistema de restrições, e seu pertencimento à formação discursiva se manifesta por referência a esses esquemas de base, que são igualmente fórmulas de uma generalidade e de um rigor máximos, que cada enunciado especifica a sua maneira. (Maingueneau, 2008, p. 70).
}

Onde sobressaem semanticamente seus sentidos na teia interdiscursiva? Alguns itens estão destacados em ND1 em negrito:

Como ocorre nessa faixa semântica: /Acredito que ações como essas, que tendem a favorecer só um determinado grupo só vão trazer dor de cabeça e mais discriminação./ presente em D123, o Outro, o discurso da negritude aparece como 
/determinado grupo/, os negros, as negras e sua negação se faz indiretamente pela defesa da /Ordem/, pois se mudar a /Ordem/, além de possivelmente favorecer os negros, irá prejudicar, deduz-se, indiretamente, os brancos, pois irá trazer /dor de cabeça e mais discriminação/. Os semas /mais discriminação/ conotam a força avassaladora do status quo que o discurso do embranquecimento abriga, pois transmutam-se numa fatalidade futura que serve para desconsiderar a realidade presente no Brasil para os negros, o que remete historicamente ao "medo branco" do avanço negro ou ao medo mais geral "das classes perigosas". No encadeamento semântico / com toda certeza a qualidade do ensino vai cair/ a hierarquia racial se desnuda, pois o Outro, o discurso da negritude, pretensamente é inferior intelectualmente e "não dará conta do recado". Já o silêncio em Q1 pode ser índice revelador da típica reprodução do silêncio sobre a questão racial no Brasil como se ela não tivesse existido na história, nem existisse no presente.

Assim, para cada unidade mínima semântica presente na superfície discursiva para o conjunto dos discursos que compõem o núcleo discursivo do embranquecimento na amostra, como os registros semânticos em negrito de cada documento, encontram-se diferentes tons do discurso do embranquecimento e diferentes modos de enunciação, mas que acorrem em conjunto para o quadro de restrição semântica global da competência discursiva postulado anteriormente para o espaço discursivo.

Por exemplo, em D175 o tom do discurso do embranquecimento calça-se na questão do mérito da nota superior do branco; já em D143 o discurso do embranquecimento ancora-se no sema/pergunta: /Os cidadãos não são iguais?/ e não consegue estabelecer relação discursiva entre o privilégio existente para os brancos no acesso à universidade no Brasil e o fato alarmante, citado na própria enunciação em Q1 que "2\% de negros estão na universidade" ou seja, é revelador de que o locutor coloca em jogo cartas embaralhadas, sem fazer as devidas conexões/argumentações. Aqui, poderíamos supor que ocorre um efeito doxa. Ou mesmo, o peso ideológico do discurso do embranquecimento cega aspectos da realidade para manter vivo o discurso.

Aprofundemo-nos na análise de D119 em particular.

É patente e pacífico que o enunciador enuncia com responsabilidade, afirmando a hipótese básica da investigação. E o faz de acordo com "o princípio de uma competência discursiva (que) permite esclarecer um pouco a articulação do discurso e a capacidade do Sujeito de interpretar e produzir enunciados que dele decorram" (Maingueneau, 2008, p. 52). 
Aparece explicitamente o sema /polêmico/ na abertura do segundo parágrafo da enunciação, sinalizando que o locutor vai entrar no jogo da interincompreensão discursiva, guiado ou não pelo interdiscurso. Não tem jeito, escancara-se o Outro dentro de seu discurso, pode-se sustentar: a presença do discurso da negritude como simulacro, como indicia o encadeamento semântico: lé o tão comentado sistema de cotas para os negros, mostrando que ainda há um preconceito muito grande na sociedade brasileira/. O enunciador entra de cabeça no jogo interdiscursivo, pois

Nesse quadro, a relação polêmica, no sentido mais amplo, longe de ser o encontro acidental de dois discursos que se teriam instituídos independente um do outro, é de fato a manifestação de uma incompatibilidade radical, a mesma que permitiu a constituição do discurso. (Maingueneau, 2008, p. 21).

Ele tece sua negação semântica do discurso da negritude com exímia competência discursiva: / Se de um lado, o sistema dá uma possibilidade de cada vez mais negros ingressarem nas camadas nobres da sociedade, por outro lado deixa explícito um verdadeiro racismo enrustido, pois discrimina os negros de uma forma deliberada.../

Nesse tema, os semas /racismo/ ou /racismo enrustido/ busca perverter o discurso da negritude, que justamente postula o combate ao racismo nada enrustido presente na sociedade brasileira e que tem cor. Há uma troca intencional dos sinais discursivos para destruir o discurso do Outro, da negritude, que torna-se simulacro. Se a condição de existência do discurso da negritude é o próprio combate ao racismo contra o negro, essa enunciação é tomada pelo locutor de D119 pelo seu reverso, ou seja, ao invés de combater o racismo ela torna-se a fábrica, o discurso gerador do racismo, contra o branco, o que indica um apagamento da histórica do Brasil para sustentar esse discurso, á medida em que o poder simbólico na história brasileira afirma o racismo conta o negro. A lança discursiva do embranquecimento aqui vista carrega um veneno em sua ponta: é o que se pode supor do sema complementar "enrustido", cuja intenção do enunciador é alimentar a polêmica emparedando o discurso da negritude pelo que ele, em tese, esconderia de intencionalidade: criar o racismo e não combater o racismo. Agora, seria o racismo contra os brancos, possivelmente. Infere-se que essa seja a postulação do enunciador, o que corrobora sua filiação discursiva ao discurso do embranquecimento, que não enxerga um Brasil sem o guarda-chuva geral branco.

O sema "mérito" aparece carregado de ironia, novamente desafiando o discurso da negritude que postula legitimamente a reserva de vagas para negros nas universidades, as cotas. 
Em Q1 o enunciador repisa seu quadro semântico, enxergado a cota como o racismo, uma leitura fatalista do futuro, que desconsidera o passado e o presente das relações raciais no Brasil, o que na prática coloca o enunciador na corrida da raia social do status quo no Brasil, de sua inalteração histórica, de sua defesa.

Quando miramos Q5, essa leitura é reforçada pela presença de outra lógica semântica incisiva: “Acorda, Polícia”, receituário enunciado para combater o /caos, a morte e a desgraça/ na periferia. Assim, ocorre um escandaloso e veemente apelo discursivo à ordem, o que reforça a adesão discursiva ao discurso do embranquecimento de modo irretorquível, pois a noção de /ordem/ é presente nessa matriz discursiva.

\subsubsection{Análise sintética geral e comum dos discursos do Núcleo Discursivo 1 em relação ao quadro de restrição semântica da competência discursiva ampliada.}

Com relação à hipótese chave dessa dissertação, no Núcleo Discursivo 1 os locutores apresentaram-se com responsabilidade discursiva.

O discurso da negritude e o discurso dos povos indígenas sofrem relativo deslocamento, para não dizer um duro ataque, dado a força discursiva do discurso do embranquecimento. $\mathrm{O}$ embranquecimento aqui se apresenta em distintos tons discursivos na dura rejeição da política de cotas para negros. Assim, no debate latente nos textos a questão da raça/cor é deslocada em função de outras variáveis. Há que se ter uma distinta percepção analítica, pois sim, esses discursos dos locutores, parte deles ao menos neste núcleo, encerram um fechamento, deixando pouquíssima abertura para uma negociação discursiva.

Com relação aos eixos semânticos, as opções discursivas assim se mostram:

1) Relação: /ordem/ orienta os discursos dos sujeitos, numa defesa do status quo avidamente ou ingenuamente.

2) Número: a ideia de /homogeneidade/ se sobressai, a questão da cor/raça é escanteada para uma posição tangencial ou mesmo foge-se de seu enfrentamento. 
3) Espacialidade: franco favorecimento da manutenção da /segregação/, tanto pelo discurso do embranquecimento como pela imutabilidade do mundo.

4) Consistência relativa: favorece o discurso do embranquecimento, por prezar pela /hieraquia racial/.

5) Intensidade Relativa: consoante o discurso do embranquecimento, há o favorecimento relativo da /invisibilidade/ e o sumiço com a questão racial. Isso se traduz numa dimensão a-histórica, como se depreende da amostra dos casos de questões simplesmente não respondidas.

6) Mobilidade Relativa: há relativo predomínio da /verticalidade/ .

7) Posição: a /periferia/ aqui pode ser tomada como /centro/, pois no frigir dos ovos discursivos os valores carregados são do status quo, do /centro/.

8) Recursos: trata-se de discursos assumidamente feito por agentes desempregados, pobres, mas também de "classe média baixa", até de camadas médias, contemplando /camadas médias e pobres/, o que é índice da inserção popular do discurso do embranquecimento no Brasil.

9) Participação: os discursos advogam uma participação cidadã e o exercício de direitos cidadãos, como do acesso à universidade, logo de acordo com a noção de /democracia ampliada/, contra uma democracia de elite, de procedimento, mas guardam uma contradição, ao escantearem a questão racial, apesar dela estar explícita nas respostas a Q1.

\subsubsection{A presença discursiva do discurso do mulatismo (ND2), o caso nodal D37 e outros exemplos: fortes indícios do discurso do mulatismo na amostra.}

No espaço discursivo em estudo, o discurso do mulatismo talvez seja o mais perturbador, pois encarna de per si o discurso de uns versos os discursos dos outros, à medida que, uma vertente do discurso do mulatismo, que sobrevive com muita força discursiva na realidade nacional caiu como uma "bomba de Hiroshima" discursiva sobre o mundo social brasileiro nos anos 1930 e seguintes, atravessando o século 20 e 
soprando século XXI afora, seja como mito eficiente ou como utopia consoladora de uma sociedade inteira.

Por isso, o discurso do mulatismo aqui em tela, serve como uma espinha dorsal, pois se no caso dos discursos do jansenismo e do humanismo devoto "A barra disjuntiva que opõe "Deus" e "Mundo" constitui, de algum modo, a espinha dorsal de todo esse discurso." (Maingueneau, 2008, p. 71). No caso do mulatismo, a disjuntiva semântica pode ser enxergada de vários modos: /harmonia/ versus /desarmonia/; /ordem/ versus /desordem/; /mistura social/ versus /separação racial/; /existência de raça/ versus /não existência de raça/; /hibridismo social/ versus / diferenças sociais/; /unionismo racial/ vesus /desigualdade racial/; /democracia racial/ versus /igualdade racial/. Essa última, pode ser tomada aqui como base analítica dos discursos do ND2, pois ela se presta para fazer emergir o discurso do mulatismo ou não, em seus variados matizes, como apropriado para a análise do ND1, em seus variados tons e modulações, pois se não há o problema do negro, então há a democracia racial, se não há o problema indígena, então há a democracia racial e se há a democracia racial, então não há porque existir o discurso pela igualdade racial. A interincompreensão e a polêmica estão no ar dos discursos do mulatismo.

Alguns casos acima ilustram isso. É o caso de D87, nessa parte semântica destacada. /Em relação a cotas para negros, não acho certo, da mesma forma haveria uma forma de pré-conceito para com eles. Fizeram uma pesquisa no fim do ano passado onde nem um terço dos alunos eram afrodescendentes nas universidades, onde deveriam ser quase metade./ De que lado da espinha dorsal semântica fica esse enunciado?

Em que pese o enunciador identificar a exclusão dos afrodescendentes da universidade no Brasil, ele parece estar inebriado pelo peso do discurso do Outro e titubeia.

O discurso da negritude não se impõe, pois o peso discursivo do mulatismo se revela retumbante em /não acho certo/, deslocando o discurso de D87 de outra possibilidade de filiação, a não ser aquela das fileiras do discurso do mulatismo.

Por reconhecer a exclusão dos afrodescendentes, outrossim, o tom do discurso de D87 pode deixar margem para negociação discursiva numa outra situação social. Mas, o /SOMOS/ maiúsculo, universalista, reforça o discurso do mulatismo, ainda que haja ironia exposta nos três pontinhos finais /SOMOS O FUTURO DA NAÇÃO.../, 
novamente, um registro de tom, que pode indicar uma não crença definitiva na teleologia anunciada ou nos sujeitos universais que a advogam.

Em D47 aparece equivalente recorte semântico: /Algo que de direitos iguais a todos, sendo o cidadão: pobre, rico, negro ou branco.

E não pensar apenas em resolver uma parte do problema, criando cotas para negros nas universidades. /, ou seja, a diferença racial é subsumida por uma noção ideal de /cidadão/, em tese uno e indiviso, portanto, não tolerante com qualquer especificidade para o outro ou a outra, negra/negro. $\mathrm{O} /$ todos/ tem tom avassalador, para o bem e para o mal. Para o bem ele supõe uma inclusão, inclusive do negro, mas a estranheza está em que pobre, rico, branco e negro, são nivelados acriticamente, como num ludibrio discursivo, pois sabidamente ricos tem lá sua cota a mais de "direitos" no real do Brasil ou não? Ao menos aqueles que os dão o poder econômico. D47 crava assim sua filiação ao discurso do mulatismo, por que não da própria democracia racial. Aparentemente, o enunciador tem dificuldade em enfrentar sozinho a força desse Outro discursivo, pois ele identifica bem o racismo logo abaixo.

Outros documentos discursivos acima corroboram esse recorte espinhal que isola /o negro/ ou a /cota para negro/ para asfaltar o caminho discursivo do mulatismo, ao gosto do desfile discursivo do status quo no Brasil. Índice objetivo de sua força, doxa e ideologia, simultaneamente.

De modo direto, ensina Maingueneau:

A "enunciabilidade" de um discurso, o fato de que tenha sido objeto de atos de enunciação por um conjunto de indivíduos não é uma propriedade que lhe é atribuída por acréscimo, mas algo de radical que condiciona toda a sua estrutura. É preciso pensar ao mesmo tempo a discursividade como dito e como dizer, enunciado e enunciação. (Maingueneau, 2008, p. 19).

Assim, outras enunciações surgem e tem aspectos relevantes para a análise. Em D282, há uma aparição semântica forte, que lembra o discurso do embranquecimento, o que comprova a hipótese desses dois discursos perfilarem na defesa da /Ordem/ no Brasil. É preciso ver com os olhos não cegos: / mas esse sistema serviria para evidenciar que o negro não tem condições de competir igualmente com os outros e aumentaria ainda mais a discriminação. É fato a situação de que os negros são mais pobres, mas pessoas brancas, indígenas, japonesas...pobres o que lhes seria feito?”/

/A menção a pessoas brancas, indígenas, japonesas ,,, pobres/ pelo enunciador, pode ser interpretada, ao menos de dois modos: 1) o enunciador está disposto a uma negociação discursiva que inclua o direito do negro e demais pessoas; 2) o enunciador vale-se 
desses outros sociais para sustentar sua restrição ao direito do negro. Aqui, sem descartar a primeira hipótese, optamos pela segunda, porque ele coloca o negro numa condição de inferioridade racial e não de sujeito de direito quando afirma que /serviria para evidenciar que o negro não tem condições de competir igualmente com os outros/, sendo que, tal visão, não vem explicitamente acompanhada no caso das outras etnias mencionadas. Mesmo assim, cremos que ao identificar que /os negros são mais pobres/ a enunciação sela possibilidades de negociação discursiva, não obstante a interincompreensão e a polêmica vista afirmar o discurso do mulatismo, em sua dimensão de unionismo, que não historiciza nem particulariza a questão do negro, pois tanto a questão do negro, como a do indígena, tem distinções históricas bastante crassas, que não foram exploradas pelo enunciador em seu discurso, o que deixa a impressão de que as outras etnias foram mobilizadas como falácia ou mero recurso retórico para fechar o sinal para o direito do negro à universidade ou para forçar o unionismo abstrato, típico da construção discursiva do mulatismo, que desconsidera as especificidades raciais, no que parece estar estruturalmente condicionado o dito, o enunciador e a enunciabilidade discursiva. Nesse caso, a responsabilidade discursiva perfila-se ao lado do discurso do mulatismo, ainda que em tom e modulação peculiar.

Noutra frente analítica sobre outros discursos presentes no ND2 e semanticamente destacados em negrito acima, vale a reflexão de Maingueneau:

Para nós, desde que os corpora de referência ocupem uma posição estratégica e desde que a reflexão se desenvolva num plano de generalidade suficiente, devemos resignar-nos a falar de todos os discursos falando apenas de alguns, mas também a falar de alguns pensando falar de todos. (Maingueneau, 2008, p. 27).

Isso se verifica pelo primado do interdiscurso, pois semas como /ordem/, do eixo semântico relação e /homogeneidade/ do eixo semântico número, à medida que são afirmados e mobilizados em discursos acima para isolarem e para rejeitarem a proposta de cotas para negros, e não raro estigmatizarem-na, em função das mais variadas propostas, e ao desconsiderarem a especificidade da proposta de cotas para negros, deslocam a heterogeneidade, reivindicando o discurso do mulatismo. É de se repor a pergunta: haveria espaço para negociação discursiva nesse quadro de interincompreensão?

A seara discursiva que está eivada desse tom acima indica discursos do mulatismo que tem o condão de falar de todos os discursos do mulatismo, ao menos 
potencialmente, nessa seara, a possibilidade de negociação fica para as margens, mas precisariam ser tensionadas discursivamente.

Que se faça agora o mergulho analítico em D37. Há um "conflito regulado" (Maingueneau, 2008, p. 37) que está presente nessa enunciação? Sim, há. Isso ganha luz nessa quadra semântica: /Foi estabelecido nesse último ano um sistema de cotas para estudantes negros, que acabou causando uma grande repercussão, os alunos que se declararam negros, dependendo da escola que frequentaram pública ou privada, já tem cotas de vagas, isso causou revolta dos alunos que se dizem-se brancos./

E esse conflito regulado exposto pelo enunciador merece seu julgamento responsável, o que é exposto semanticamente:/ o sistema de cotas na minha opinião não irá funcionar já foi feito nos EUA e não teve um bom resultado/. O conflito discursivo regulado tende, no discurso do enunciador, para a /ordem/, para a /homogeneização/.

Mas, o enunciador revela nuances discursivas, modalização, um tom peculiar. Ele deixa ver que /Mesmo assim sou a favor das cotas, com algumas mudanças as cotas seriam para alunos que estudam em escola pública não importando se forem negros ou não./

O /não importando se forem negros ou não/, coloca imediatamente o negro excluído da universidade sob um pretenso manto geral da /homogeneidade/ que adviria, na proposta do enunciador, das cotas para a escola pública.

Meio que sutilmente ou não, ingenuamente ou não, esse ponto é suficiente para informar a adesão do enunciador ao discurso do mulatismo, onde não haveria o problema da raça no Brasil ou mais incisivamente, ao discurso da democracia racial, que some, desaparece, leva à invisibilidade a questão do negro.

Entrementes, o enunciador deixa, implicitamente, margem para uma negociação discursiva. Apesar de engolir o discurso da negritude sob o manto de um /homogêneo/ que desloca a heterogeneidade negra e mesmo indígena.

Essa possível margem de negociação discursiva do enunciador ganha fôlego por seu pleno reconhecimento do /preconceito/ e do /racismo/ e de que /há um preconceito muito grande em relação ao negro, tudo o que acontece de pior é relacionado à sua cor negra./

Mas, como o registro da condição social real do negro não foi suficientemente relacionado com uma política que o leve para a universidade, por exemplo, o manto invisível que paira sobre o discurso na redação garante a responsabilidade discursiva do enunciador perfilada junto ao mulatismo, ainda que num tom particular. 


\subsubsection{Análise sintética geral e comum dos discursos do Núcleo Discursivo 2 em relação ao quadro de restrição semântica da competência discursiva ampliada.}

Em relação a hipótese chave dessa dissertação, no Núcleo Discursivo 2 também os locutores apresentaram-se com responsabilidade discursiva. O discurso da negritude e o discurso dos povos indígenas sofrem relativo deslocamento, dado a força discursiva do discurso do mulatismo, não é demais repisar, sustentado no discurso da democracia racial no Brasil. Assim, no debate latente nos textos a questão da raça/cor é deslocada em função de outras variáveis. Há que se ter aguda percepção analítica que esses discursos dos locutores não informam um fechamento, deixando graus de abertura para negociações discursivas, ao contrário do maior das vezes dos discursos do ND1.

Com relação aos eixos semânticos, as opções discursivas assim se mostram:

1) Relação: /inovação/ e /ordem/ parecem conviver nos discursos dos sujeitos, em que pese a identificação contraditória nos textos da desigualdade racial presente na realidade brasileira, os discursos dos sujeitos, nesse sentido, parecem não estabelecer a relação entre a condição social e racial objetiva do negro e a necessidade de políticas para superá-las, por isso no eixo semântico relação, tudo indica que uma /inovação/ precisa se estabelecer em compasso com a /ordem/, o status quo é tangencialmente questionado.

2) Número: /heterogeneidade/ e /pluralidade/, não se apresentam com suficiência nos discursos para deslocar a ideia de /homogeneidade/.

3) Espacialidade: /integração/ é apontada pelos agentes para enfrentar a /segregação/. Mas, antes uma integração centrada na questão da renda, no limite da classe social, ao desconsiderar a questão racial, na prática, os discursos favorecem o discurso do mulatismo, o que favorece a manutenção da /segregação/.

4) Consistência relativa: favorece o discurso do mulatismo, que preza pela /hieraquia racial/, favorecendo os brancos, dados os discursos dos sujeitos. 
5) Intensidade Relativa: consoante o discurso do mulatismo, os discursos no ND2 favorecem a /invisibilidade/.

6) Mobilidade Relativa: ocorre tensa negociação entre /horizontalidade/ e /verticalidade/ nos discursos presentes em ND2.

7) Posição: os sujeitos assumem a fala, o discurso e o ethos da periferia brasileira, /periferia/, mas paradoxalmente, carregam o discurso do /centro/.

8) Recursos: trata-se de discursos assumidamente feito por agentes desempregados, pobres, mas também de "classe média baixa", até de camadas médias, contemplando /camadas médias e pobres/, o que é índice da inserção popular do discurso do mulatismo no Brasil, particularmente no seu grande vértice, o discurso da democracia racial.

9) Participação: os discursos advogam uma participação cidadã e o exercício de direitos cidadãos, como do acesso à universidade, logo de acordo com a noção de /democracia ampliada/, contra uma democracia de elite, de procedimento, mas guardam uma contradição, ao escantearem a questão racial, apesar dela estar explícita nas respostas às questões, na maioria das vezes. Na hora da relação com uma possível política de superação, o primado do interdiscurso trava. No caso o forte discurso da democracia racial, presente nas estruturas sociais e mentais.

\subsubsection{A presença discursiva do discurso do indianismo e o caso nodal D212 (ND3).}

O discurso do indianismo se faz presente por sua retumbante ausência vis-à-vis aos outros discursos.

Mas, então, como ele está no jogo interdiscursivo: com a agressividade da invisibilidade e do silêncio, pois não falar é uma forma ácida de indiferença.

E o fato do discurso do indianismo não ganhar escala relativa na amostra era uma hipótese aventada quando dos estudos sobre o questionário sócioeconômico e sobre o teor mas mediações epistêmicas, pois raros indígenas participaram da avaliação de conhecimento. 
Em que pese isso, o discurso do indianismo se faz presente como sua verve discursiva mais terrível no Brasil: como alegoria.

É o que se vê em traços semânticos presentes em D212: / As cotas para mim cria um certo racismo não só para com os negros mas também para com os indígenas os nordestinos porque não é só negro que é pobre e estuda em escola pública./

O enunciador aqui assume o discurso do indianismo ao não postular o direito do indígena real, mas sim ao usá-lo, como discurso de ocasião, entre a alegorização e a coisificação do indígena, como escudo de parede para negar as cotas porque elas /cria um certo racismo/. Acaso as cotas inventaram o racismo contra o indígena? Criaramno? O racismo contra o indígena não existiu por mais de quinhentos anos sem cotas?

Aqui surge a noção etérea do /índio eterno/, sempre o mesmo, que vira outro conforme se maneje o discurso do indianismo na história, como aquela cena de cinema em que os indígenas eram obrigados a vestirem as roupas brancas do SPI (Serviço de Proteção ao Índio) feitas de sacos, para virarem civilizados nos anos 1910, o que lhes rendeu doenças de toda ordem pelo paulatino apodrecimento e sujeira que a mesma roupa carregava de tanto uso, os tais casacões e calças brancos de estopa para homens e mulheres indígenas igualmente trajados de civilizados, como deixa ver o filme de Sérgio Bianchi. Outro para continuar o mesmo: invísibilizável, alegorizável, mobilizável para o gosto de ocasião.

D212 faz o manejo com responsabilidade discursiva do discurso do indianismo, daí se filiar, ingenuamente ou conscientemente. Indíce da superfície discursiva apenas ou da impregnação discursiva do discurso do indianismo nas estruturas corporais/mentais.

Há marcas esparças desse mesmo registro no corpus, mas esse um é suficiente.

Em tempos de internet, sujeitos mais fragmentados ainda como os 305 povos indígenas brasileiros, os sujeitos fragmentados da classe trabalhadora mais fragmentada, levam os chicotes da invisibilidade de todos os lados.

Não custa aqui fazer uma crítica dura a uma falsa polêmica levantada por SOUZA (2006), que em seu longo arrazoado, sustenta a certa altura: "Essa visibilidade da "raça" é conquistada pela invisibilidade da "classe" como dimensão cultural e simbólica de natureza não econômica".

A classe aparece a todo momento no corpus, bem como sua invisibilidade. A invisibilidade indígena, que é também da raça indígena aparece, assim como a invisibilidade negra pulula no corpus, na amostra. 
É a visibilidade da classe dos proprietários latifundiários históricos no Brasil e seu discurso do indianismo, no entanto, que torna invisível a raça negra presente nos quilombos rurais e as própria raças indígenas. O Brasil não é a Europa. Essa invisibilidade ao longo dos tempos e nestes tempos de sujeitos históricos fragmentados tem colocados indígenas e negros não apenas invisíveis enquanto metáfora, mas embaixo da terra mesmo, que o digam a invisibilidade nos cemitérios de muitos semterra no Brasil, para não ficarmos nos quilombolas e nos indígenas invisibilizados pelas balas.

Nada mais visível no Brasil do que a classe dos grandes proprietários rurais, seus poderes simbólicos, sua enorme bancada ruralista no Congresso. Seu habitus de inviabilizar seus oponentes, como aqueles dos discursos da negritude e dos povos indígenas que ocuparam o processo constituinte de 1987/1988.

\subsubsection{Análise sintética geral e comum dos discursos do Núcleo Discursivo 3 em relação ao quadro de restrição semântica da competência discursiva ampliada.}

O discurso do indianismo visto apresenta inegável responsabilidade discursiva, ratificando a hipótese. Outros traços avulsos do discurso do indianismo estão diretamente ou indiretamente presentes na amostra, no que não foi avançado para esse grau detalhado de análise. Com relação ao quadro de restrição semântica, percebe-se que:

1) Relação: /ordem/ é o grande moto discursivo do indianismo, ao passo que o próprio indígena, em muitos casos, vagar entre a coisa e o marciano, fora da ordem.

2) Número: /homogeneidade/ é a senha do discurso do indianismo, a tal extremo que a receita da morte não é rara para a heterogeneidade que perturbe.

3) Espacialidade: /segregação/ é apontada pelo discurso indianista para a reprodução do status quo secular em seus latifúndios.

4) Consistência relativa: /hieraquia racial/ evidente, como o discurso do indianismo calcado nos grandes proprietários brancos de terras. 
5) Intensidade Relativa: consoante o discurso do indianismo há um favorecimento da /invisibilidade/ indígena e negra, ao troco da plenipotente visibilidade dos grandes proprietários, sua classe e seu poder simbólico.

6) Mobilidade Relativa: /verticalidade/, pois a regra é a herança ou a posse das terras por grandes capitais nacionais ou forâneos, o que muitas vezes, quase que, automaticamente, implica na passagem do bastão do discurso do indianismo, o adversário pela posse da terra vasta.

7) Posição: os sujeitos assumem a fala, discurso e o ethos do /centro/ do poderio agrícola nacional, seja ele econômico, político ou simbólico.

8) Recursos: trata-se de discursos assumidamente feito por agentes em posição de enorme concentração de poder: econômico, político, simbólico, social.

9) Participação: Lógica discursiva das elites patrimonialistas na tradição brasileira da disputa pelo poder de Estado, onde o Estado é quase a extensão da fazenda. A participação não é incentivada, nem tolerada, pois as tratativas dos assuntos públicos, em muitos casos, resolvem-se entre famílias, no âmbito doméstico.

\subsubsection{A presença discursiva do discurso da negritude (ND4).}

Se "a menor unidade discursiva supõe o acionamento do sistema de restrições" semânticas, por que não o fazê-lo aqui, de imediato, pari-passu, valorizando os locutores, as locutoras, para colocar um pouco de condimentosinho analítico? Vamos enunciado por enunciado, pois. Caro leitor, cara leitora, o objetivo aqui é compartilhar mais de perto os horizontes discursivos, os comentários breves das partes destacadas da amostra para, com os ensinamentos da educação popular brasileira, "dar voz aos que não tem voz nem vez”. Isso está de acordo com a teoria esposada, pois,

$\mathrm{O}$ ato de enunciação supõe a instauração de uma "dêixis" espaciotemporal que cada discurso constrói em função de seu próprio universo (em linguística, entende-se por isso o conjunto de localizações no espaço e no tempo que um ato de enunciação apresenta, graças aos "embreadores" (ou "shifters"). ...Da mesma forma, a dêixis a partir da qual o enunciador jansenista profere não é a França do século XVII, mas a Igreja primitiva, a mais próxima possível das origens...

Essa dêixis, em sua dupla modalidade espacial e temporal, define de fato uma instância de enunciação legítima, delimita a cena e a cronologia que o discurso constrói para autorizar sua própria enunciação. ...

De uma maneira ou de outra, trata-se de estabelecer uma cena e uma cronologia conformes às restrições da formação discursiva. 
Mas um discurso não é somente determinado conteúdo associado a uma dêixis e a um estatuto de enunciador e de destinatário, é também uma "maneira de dizer" específica, a que nós chamaremos de modo de enunciação. (Maingueneau, 2008, p. 88/90)

Nessa toada, em D179, cabe destacar a "maneira de dizer", bastante direta, como mostra o trecho em destaque: "Existe um outro problema muito sério em relação as universidades públicas ou não, são os negros e os deficientes físicos. São poucos os negros que frequentam uma faculdade, e quando as frequentam são a minoria. Geralmente poucos são vistos com bons olhos, e quando aceitam são pela sua condição financeira, ai todos o querem, agora quando isso não acontece eles os querem também mas pelas costas."

Essa semântica negra, da perifeira, essa dêixis profunda na história do Brasil, expõe as duas dimensões da polêmica interdiscursiva: /São poucos os negros que frequentam uma faculdade, e quando as frequentam são minorias/ e /agora quando isso não acontece eles os querem também mas pelas costas/. Aqui o discurso da negritude mostra-secom força simbólica, responsabilidade discursiva e mais, demonstra generosidade e solidariedade para com os deficientes. Por outro lado, não vacila discursivamente, identifica o discurso de uns (do embranquecimento ou do indianismo ou do mulatismo) como simulacro, o corte é cirúrgico: "mas pelas costas". A polêmica interdiscursiva aqui é a pulsação do real social por direitos historicamente negados.

No próximo passo enunciativo, a cena do cotidiano onde se inscreve o locutor que legitima sua inscrição discursiva na história. Em D200, aparece “...conta a idade, conta o que restou' na realidade o tempo da escravidão já passou mas a sociedade ainda discrimina o negro. E parece que pode passar o tempo que Passar, algumas pessoas ainda será rascista com o negro." e "Infelizmente o nosso cotidiano é basicamente igual a letra da musica, um deles é a falta de emprego. Pois sem o emprego a pessoa não tem como se manter e suprir s violência."

Do cotidiano do enunciador D200 salta aos olhos a falta de emprego. Os olhos enxergam a realidade, dos casulos do cotidiano saem os discursos e o sujeito enuncia aqui com responsabilidade na gradação mínima, mas semanticamente suficiente para expor as brasas do interdiscurso: /E parece que pode passar o tempo que Passar, algumas pessoas ainda será rascista com o negro./ Aqui, o discurso da negritude registra sua morada na história: presente, passada e futura e divisa seu Outro discursivo muito bem. 
Segue o andor discursivo e analítico até o enunciador D131 e se depara com vida em abundância:"Tenho 19 anos, nasci e me criei na periferia. Sempre estudei em escolas públicas e sempre tive o sonho de fazer um curso de nível superior em faculdade pública. Mas quando completei o ensino médio o sonho virou ilusão, porque nunca tive um suporte de ninguém nem do governo.Mas eu e muitos outros como eu que não tem ajuda de ninguém achamos que temos direito de termos uma universidade.Uma universidade que respeite o nosso nível social e cultural e nossa raça. Acho muito interessante cotas para os negros, mas não é só isso que vai resolver o problema, e não acho que é uma discriminação racial pois realmente a maioria dos negros não tem condições de frequentar uma universidade."

O enunciador D131 assume o discurso da negritude com tons e notas particulares, mais de peito aberto, de modo desabrido: ele fala o que fala do lugar onde fala com o corpo que fala, não dá pra duvidar. $O$ arranjo semântico trazido pelo enunciador explicíta o discurso da negritude, do direito do negro à universidade, sem meias palavras /Uma universidade que respeite o nosso nível social e cultural e nossa raça. Acho muito interessante cotas para os negros, mas não é só isso que vai resolver o problema, e não acho que é uma discriminação racial pois realmente a maioria dos negros não tem condições de frequentar uma universidade./

Simultaneamente, ele não tem ilusões sobre as cicatrizes da história para o povo negro brasileiro. O interdiscurso, o discurso do outro é negado enfaticamente em dois tópicos mais detalhadamente: /nossa raça/ e /não acho que é uma discriminação racial/. Nesses tópicos discursivos, diretamente ou indiretamente, ele entra no jogo e nega o discurso do embranquecimento, o discurso do indianismo e o discurso do mulatismo, até sua vertente venenosa da democracia racial. O enunciador não se acovarda pelo manto predominante da democracia racial tomada como doxa, muitas vezes, no Brasil.

Pelo caminho, outro enunciador discreto, D 169. O que diz? Um tiquinho de nada, dentre outras coisas, um indício discursivo: "Por mais que as pessoas digam que o negro não é discriminado isso não é verdade, existe a discriminação em todo o país, as vezes são julgados com pequenas coisas, como por exemplo as roupas que usam numa entrevista de emprego. De um olhar eles já são considerados ladrões."

Em D 169, o aspecto semântico que se destaca nessa enunciação diz respeito ao corpo negro e a presença do interdiscurso como uma relação dialógica pelo olhar, os outros discursos, possivelmente de corpos não negros ou no limite, até mesmo de negros, tem uma interação discursiva pelo olhar: /De um olhar eles já são considerados 
ladrões/. A violência simbólica invade o interdiscurso para estabelecer os conflitos regulados, o corpo se envolve, o jeito de olhar é um indício do discurso que negra o discurso da negritude evidenciado pelo próprio corpo do negro ou da negra, cujas consequências para as crianças negras são terríveis.

Na quebrada discursiva próxima, em D191, o tom discursivo tem distinção "Espero que daqui a uns cinco anos não exista mais isso e que brancos e negros estudem em universidades sem discriminação que não tenha mais num tipo de discriminação nem contra negros nem contra nada. Preconceito, é ladrão e isso e aquilo. Mas os negros estão buscando seu respeito sua dignidade.

Essa enunciação dá um tom particular ao discurso da negritude, refutando o estigmatização pelo discurso do ódio, postulado e atribuido por muitos discursos vistos no espaço discursivo, ao discurso da negritude: há uma nota de esperança que se sobressai na enunciação de D191, esperança numa realidade social e racial diferente do presente vivenciado pelo enunciador, o que se traduz na concatenação semântica: / Espero ... dignidade/ $\mathrm{O}$ enunciador entra no jogo interdiscursivo, esconjura seus adversários e enuncia sereno e com fé /que brancos e negros estudem em universidades/ pois isso não ocorre no momento da enunciação, que é também um clamor por justiça. A dimensão histórica de justiça no discurso da negritude contra o enfrentamento discursivo com o discurso do embranquecimento, do indianismo e do mulatismo, aparece de forma lacerante num excerto solto num rascunho do corpus, de imensa força semântica e narrativa: /Os filhos dos escravos estão excluídos e isso foi o que herdaram. Nunca o Brasil corrigiu o crime que cometeu contra os negros/.

Na passarela discursiva, surge D235, para jogar o campeonato interdiscursivo: “Quando se fala de saber quem tem mais mérito, se é o estudante de escola pública que tira nota 6 ou o de escola particular que tira nota 8 , realmente, não há como se dizer, considerando-se as condições de formação escolar de cada um. (l 23 a 29).

Não sou totalmente contra o sistema de cotas, pois estas seriam uma maneira de tentar diminuir as desigualdade sociais e raciais na hora de ingressar no ensino superior. Mas acho que as desigualdades sempre irão existir enquanto todos os conceitos e critérios educacionais não forem revistos." (1 42 a 50).

O enunciado presente em D235 entra no jogo para valer. O primado do interdiscurso avança logo de cara. A pista semântica é óbvia demais: /quem tem mais mérito, o estudante de escola pública que tira nota 6 ou o de escola particular que tira nota 8 , realmente, não há como se dizer/. Por essa via ela deixa nu um dos marcos 
discursivos do mulatismo, do indianismo e do embranquecimento, já vistos, relativizando as condições de comparação entre os agentes oriundos da escola pública e da escola particular.

E, num tom particular, o enunciador assume o discurso da negritude e nega automaticamente aqueles concorrentes, com suavidade e esteira semântica que sinaliza um caminho amplo analítico e discursivo: / Não sou totalmente contra o sistema de cotas, pois estas seriam uma maneira de tentar diminuir as desigualdades sociais e raciais na hora de ingressar no ensino superior./

Ao fazer a ponte entre o cotidiano e a história ensejada pelas questões Q1 e Q5, a enunciação encoraja uma interpretação que autoriza a enxergar em seu discurso uma semântica global que toma posição discursiva perante o todo social, com destemor frente os mores discursivos da /ordem/ e em favor de /inovação/, pois / a maioria dos empresários, executivos e donos de empresas são brancos. A porcentagem de negros no ensino superior também é ínfima. Enquanto não houver melhores oportunidades e menos distinção racial e social isso nunca irá acabar./ Assim, há a negação do discurso do embranquecimento, do mulatismo e do indianismo, nos marcos possíveis vistos, mas no mais que o espírito discursivo e a modelização discursiva particular dessa enunciação enseja.

Já em D2, esse enunciador desafia o universal apregoado pelas elites brasileiras em seus respectivos discursos do embranquecimento, do indianismo ou da negritude, nas tonalidades que lhes são de praxe, mas que giram em torno da posse do igual definido pelo Estado. Enuncia D2: “O sistema de cotas, talvez não seja o ideal para a comunidade negra como um todo, mas, temos que tratar desigualdade com desigualdade, só assim chegaremos à igualdade." ..."as cotas.. com certeza absoluta irá diminuir a distância que existe entre os povos de nosso país".

Nesse locutor, o primado do interdiscurso repõe o questionamento da condição da igualdade no Brasil. O enunciador assume o discurso da negritude para postular uma igualdade racial, insistindo para tanto na chave semântica de /tratar desigualdade com desigualdade/, negando a /homogeneidade/ pretendida por uma igualdade meramente formal e abstrata, comum nos núcleos discursivos vistos, como em ND1 e ND2. A enunciação de D210 ecoa o discurso da negritude com uma inscrição histórica particular, pois a igualdade formal não lhe tratou com /homogeneidade/ no seu direito à universidade, ponto de partida de sua enunciação crítica a /ordem/ e favorável à /inovação/: "Em um ponto de vista mais avançado a cota pode ser a solução para os 
afrodescendentes mostrar que são capazes de conquistar seu próprio espaço na sociedade. No meu caso faz dois anos e meio que conclui o ensino médio e até agora não tive oportunidade de entrar em uma faculdade."

Por fim, cabe aqui destacar o tom e o modo de articulação discursivo ímpar presente na enunciação feita pelo locutor em D78 de modo a enfrentar arranjos discursivos presentes na polêmica, como vistos para os ND1 e ND2, ao menos.

O locutor assume o discurso da negritude e o constrói negando, pelo interdiscurso, os outros discursos que lhe desafiam. A todo instante isto está presente na superfície discursiva e em outros planos, como na questão da /visibilidade/ versus uma receitada eterna /invisibilidade negra/.

A interincompreensão semântica, o jogo interdiscursivo é jogado num tom afirmativo do discurso da negritude e negando seus oponentes à altura da polêmica instalada, num tom elegante e com exímia maestria para o tema.

A locução é autoexplicativa e enfeixa esse primeiro passo analítico para o ND4, que abriga espaço para negociação discursiva, por tudo que se viu em ND4, bom que se frise, como é o caso de uma possível negociação com o discurso dos povos indígenas. Segue a enunciação:

"É evidente que a mudança deveria ser feita no ensino médio, ao invéz de ser feita já no ensino superior, porém isso levaria muito tempo, caso as mudanças fossem feitas hoje com alunos de escola pública da 8 série, levaria cerca de 4 anos para saber se eles irão competir com igualdade no vestibular, mais três anos para saber-mos se eles conseguirão acompanhar o curso, sem que a instituição perca qualidade de ensino e mais uns dois anos para saber-mos qual será a posição desse profissional diante do mercado.

Em média levaríamos dez anos para começarmos a enchergar algumas mudanças.

Porém é necessário algumas mudanças imediatas, para ter-mos resultados imediatos.

Por isso sou a favor das cotas para negros na universdidade, acho que seria um bom começo, daqui 4 ou 5 anos já teríamos uma mudança bem visível com relação aos afrodescendentes no mercado de trabalho e consequentemente na sociedade como um todo.

Pode até ser que o processo de cotas façam com que algumas pessoas com deficiência na educação cheguem até a universidade e desistam por não conseguir 
acompanhar os outros alunos, mas em contrapartida fará com que muita gente realmente esforçada chegue até lá e diante do curso se desenvolva tão bem que se tornará um ótimo profissional.

Ou então as duas mudanças (as cotas e a partir da 8 série) podem ser feitas simultaneamente, assim teremos soluções boas a curto prazo e soluções melhores ainda a longo prazo, o que não pode é não ser feito nada." (l 1a 44).

\subsubsection{Análise sintética geral e comum dos discursos do Núcleo Discursivo 4 em relação ao quadro de restrição semântica da competência discursiva ampliada.}

Em relação a questão central dessa dissertação, no Núcleo Discursivo 4 os locutores apresentaram-se com responsabilidade discursiva. Os discursos do embranquecimento e do mulatismo sofreram relativo deslocamento, o que pode-se dizer alicerçados nos discursos da negritude, com construções discursivas ímpares. Com relação aos eixos semânticos, as opções discursivas assim se mostram:

1) Relação: /inovação/, os discursos dos sujeitos, nesse sentido, negam a /ordem/, o status quo.

2) Número: /heterogeneidade/ e /pluralidade/, deslocam a ideia de /homogeneidade/.

3) Espacialidade: /integração/ é apontada pelos agentes para enfrentar a /segregação/

4) Consistência relativa: /mobilidade social e racial/ e /igualdade racial/ são assumidas pelos discursos dos sujeitos.

5) Intensidade Relativa: /equidade, visibilidade e liberdade/ para o sonho dos Sem Universidade contra o /status quo, a exploração e a invisibilidade/

6) Mobilidade Relativa: registra-se o apelo por /horizontalidade/ contra /verticalidade/ nos discursos presentes em ND4.

7) Posição: os sujeitos assumem a fala, o discurso e o ethos da periferia brasileira, /periferia/, pois. 
8) Recursos: trata-se de discursos assumidamente feito por agentes desempregados, pobres, mas também de "classe média baixa", até de camadas médias, contemplando /camadas médias e pobres/, por negros e negras que assumem o discurso da negritude.

9) Participação: os discursos advogam uma participação cidadã e o exercício de direitos cidadãos, como do acesso à universidade, logo de acordo com a noção de /democracia ampliada/, contra uma democracia de elite, de procedimentos.

\subsubsection{A presença do discurso dos povos indígenas (ND5).}

O discurso dos povos indígenas ocupa espaço na amostra, ao menos em três enunciações, onde são diretamente abordados: D262, D286 e D299. Isso ocorre, entretanto, apenas lateralmente, o que indicia a lateralidade com que esse discurso se fez presente. Porém, lateralidade suficiente para expor o confronto discursivo, para garantir mínima /visibilidade/ e /especificidade/, semânticas centrais na afirmação do discurso dos povos indígenas no Brasil.

Assim, em D262 o locutor tece sua enunciação contra a /verticalidade/, a /homogeneidade/,entrando no jogo, pois afirma que /as instituições de ensino são omissas/ e que /deveriam atuar junto as comunidades carentes/, pois assim /poderiam desenvolver os chamados programas de cotas [para estudantes de origem indígena, negros e pobres] fazendo-os evoluir/.

Esse registro enunciativo realça a especificidade dos povos indígenas, versus o tratamento discursivo da /homogeneidade/. É, nesse ínterim, registro mínimo, mas suficiente do discurso dos povos indígenas no jogo interdiscursivo, na interincompreensão instalada no espaço discursivo.

Como fica evidente, há margens para negociações discursivas, em particular, com o discurso da negritude. Mas, ressalte-se, no Brasil, a/especificidade/ indígena diz respeito a grandeza do território e ao número de povos indígenas.

Já o locutor D286 enuncia batendo de frente com o discurso do indianismo, do embranquecimento ou mesmo do mulatismo, pois sustenta que /muitos políticos falam que não tem nem um tipo de preconceito, mais são os primeiros a ter, se não tivessem, 
os negros, os índios, os pobres teriam mais liberdade num país como esse.”. Ora, a /concentração/ de terra, de poder político é marca fulcral do discurso do indianismo que tem enorme representação no Congresso Nacional, ao passo que os povos indígenas praticamente não tem representação alguma.

\subsubsection{Análise sintética geral e comum dos discursos do Núcleo Discursivo 5 em relação ao quadro de restrição semântica da competência discursiva ampliada.}

Em relação a questão central dessa dissertação, no Núcleo Discursivo 5 os locutores apresentaram-se com responsabilidade discursiva. Os discursos do embranquecimento e do mulatismo sofreram relativo deslocamento, e um enfrentamento mais incisivo ao discurso do indianismo, o que apenas lateralmente indicia a presença do discurso dos povos indígenas. Com relação aos eixos semânticos, as opções discursivas assim se mostram:

10) Relação: /inovação/, os discursos dos sujeitos, nesse sentido, negam a /ordem/, o status quo em prol da /especificidade/ da questão indígena.

11)Número: /heterogeneidade/ e /pluralidade/, deslocam a ideia de /homogeneidade/.

12)Espacialidade: /especificidade indígena/ está presente indiretamente para enfrentar a/integração forçada/ ou /assimilação subordinada/.

13)Consistência relativa: /mobilidade social e racial/ e /igualdade racial e especificidade dos povos indígenas/ são lateralmente indicados pelos sujeitos.

14)Intensidade Relativa: /equidade, visibilidade e liberdade/ para o sonho dos Sem Universidade indígenas contra o /status quo, a exploração e a invisibilidade/

15) Mobilidade Relativa: registra-se o apelo por /horizontalidade/ contra /verticalidade/ nos discursos presentes em ND5.

16) Posição: os sujeitos assumem a fala, o discurso e o ethos da periferia brasileira, numa dimensão de espalhamento e posse da terra dispersa dos povos originários.

17) Recursos: trata-se de discursos assumidamente feito por agentes desempregados, pobres, mas também de "classe média baixa", até de camadas médias, 
contemplando /camadas médias e pobres/, que se solidarizam com a questão dos povos indígenas.

18) Participação: os discursos advogam uma participação cidadã e o exercício de direitos cidadãos, como do acesso à universidade para os indígenas nas cotas, logo de acordo com a noção de /democracia ampliada/, contra uma democracia de elite, de procedimentos.

\section{Fragmentos discursivos coletivos presentes no corpus.}

Haveria diversas formas possíveis de "enquadrar" as enunciações abaixo em algum modelo teórico, em algum compartimento etc. Porém, na esteira do estudo analítico, trata-se de práticas discursivas que emergem meio que espontaneamente, meio que não, de dentro das quebradas discursivas, sob a locução de sujeitos fragmentados, de realidades duras e fragmentadas, logo distantes de qualquer laço dogmático apriorístico que os abarque, digamos, em sentido ideológico.

Trata-se de reivindicações coletivas, individuais, desabafos desesperados, apelos para uma ação coletiva, de qualquer forma.

Esses fragmentos, pelo até aqui visto, são territorializados, tem evidente dimensão de classe social, de disputa por capital cultural e remetem a homens e mulheres também fragmentados, mas não assujeitados, pois eles clamam pra valer, em um tom até desesperado por direitos, em especial o direito à universidade.

Se não são os sujeitos clássicos da revolução trabalhadora, esses tipos-ideais, tampouco são os novos sujeitos sociais que emergiram no quadro da ditadura militar no Brasil. Quem são esses sujeitos fragmentados com causas fragmentadas?

A leitura atenta do caleidoscópio de suas enunciações indicia fortemente a presença de novíssimos sujeitos sociais nos territórios da periferia da grande cidade.

Essa leitura é necessária e ela é elencada empiricamente abaixo desde a base documental do corpus pela voz "torta" dos próprios sujeitos, sem plainas. Às enunciações pois.

Enunciados presentes em D105:

R: "Quando tratamos do tema educação nos deparamos com um diagnóstico no mínimo vergonhoso, onde maior parte da população está privada ou deficiente de algo que lhe é essencial e constrói cidadania.O tema é amplo, envolve as políticas de ensino 
público, os atuais sistemas de avaliação da educação, as condições das escolas, como também o meio onde está inserida, o papel do vestibular como forma de inclusão e não exclusão social, as propostas alternativas como por exemplo as cotas para negros e o PAS (Programa de Avaliação Seriada), o ENEM e sua razão de existir, o nicho de mercado que está atraindo o ensino privado." (1 1 a 15).

"Como fora dito educação é a base, do avanço, da tecnologia, da inclusão, da cultura. Sendo alicerce não temos outro caminho se queremos um Brasil que seja de todos, a palavra de ordem é LUTA a bandeira IGUALDADE."( 136 a 40).

Enunciados presentes em D81:

R: "Enfim, acho que o sistema de ensino no nosso país tem de ser reavaliado e mudado, de um modo que beneficie à todos, não só a nós brasileiros, mas também ajudará no crescimento do nosso país.”(1 49 a 52).

Enunciado presentes em D80:

R: "É por isso que digo continuo com medo de nunca frequentar uma universidade". (1 42 a 45).

Enunciados presentes em D205:

R: "Que o nosso objetivo é entrar na faculdade. Sabemos que é difícil, mas não impossível, não podemos pensar que um aluno da escola particular é melhor que da escola pública. A capacidade é a mesma, o que está errado é o ensino das escolas”.

Enunciados presente em D206:

R: "Quando terminei meu curso em 1995, não exisitia muitos meios para que eu pudesse engressar em uma "USP" ou "FATEC" que existe em São Paulo"... "Comecei em 1997 na "UBC" Universidade Brás Cubas em Mogi das Cruzes cursando comércio exterior. Logo no primeiro mês, percebi que o dinheiro que guardava não daria para poder pagar as mensalidades"... "Contudo, sinto que novamente meu sonho não esta acabado, quero poder novamente planejar meu currículo escolar com essa nova oportunidade que vêm sendo dada."

\section{Enunciados presentes em D77:}

R: "[...], pois, ao que se parece, o governo não dispõe de um pouco mais de atenção para com este assunto e assim não vê a real dificuldade que uma pessoa de 
baixa renda tem para entrar numa Universidade, não pela falta de força de vontade, mas sim pela falta de oportunidade e com isso tudo vem ficando mais difícil, principalmente um emprego digno, pois sem qualificação nada se consegue." (132 a 41).

Enunciados presentes em D73:

$\mathrm{R}$ : “O jovem deve lutar pela reforma educacional, pelo contrário será submetido a um estudo irrelevante e de nenhum preparo". (151 a 53).

Enunciados presentes em D110:

$\mathrm{R}$ : "Eu só sei que muita coisa tem que mudar do que se fala do direito de acesso a universidade aqui no Brasil. Porque em outro países pelo o que eu ouço falar é bem diferente"(1 38 a 42).

Enunciados presentes em D116:

R: "Precisamos que o governo olhe a situação do povo e crie novas universidades públicas e que construam também cursos pré-vestibulares para que as pessoas tenham orientação de como estar preparado para os vestibulares mesmo não tendo condições de estudar numa escola particular.”(137 a 42).

Enunciados presentes em D67:

R: "Tudo isso que escrevi são apenas ideias um estudante pobre não tem muita esperança de cursa uma Faculdade, pois não tem nem condições de pagar a taxa de inscrição de uma universidade pública, que por sinal é um absurdo que dirá um bom cursinho para passar nesta. É se as coisas não mudarem as universidades públicas constinuará com os alunos que tem condições de pagar e as coisas vão continuar na mesma, quem tem tomando o lugar de quem não tem. Bom termino por aqui minha Redação e espero que as coisas mudem, e que o nosso Presidente de insentivo aos alunos pobres." (134 a 47).

Enunciados presentes em D356:

R: "Devemos então reivindicar, para podermos transformar nosso país mais justo em questão de educação, mas para isso os isolados e oprimidos devem exigir mais e expor suas idéias de maneira que devem ser respeitadas." (1 19 a 23). 


\section{Enunciados presentes em D65:}

R: "Acho que todas as tentativas para melhorar o entendimento e as chances de todos os estudantes entrarem numa universidade, é válido. Haverá muitas questões, aprovações e implicações, mas para quem tem um objetivo, isso será apenas um mero obstáculo. Afinal, todos nós temos o direito à educação, só precisamos saber como reivindicar de uma maneira correta, adequada e justa para todos." (1 33 a 44).

Enunciados presentes em D344:

R: "[...] tudo é sempre muito relativo esses varios depoimentos que você pode presenciar são de pessoas que tem chance que são de famílias ricas ou de de ótima condição de vida salarial Dizem que é preciso ter "boa" condição, mas você escolhe com a boa condição ou você come ou você estuda.

Os ministros do nosso país da nossa terra não sabem administrar a nossa situação a nossa pobreza o mais importante para eles não são negros inteligentes mais sim brancos milionários.

Dão várias oportunidades mais que delas mesmo nos pobres nunca tiramos proveito dizem que entrar na universidade e sonho de pobre mas algum dia esses pobres irão ser o futuro da nação e tudo o que era sujo e ipocrita vai a ser desmascarado, pois todos temos assim como deveres direitos iguais e não digo todas mais se apenas $20 \%$ dessas universidades aderissem os direitos dos alunos carentes, pobres tudo seria diferente, tudo seria extremamente diferente, tudo seria um sonho pois $\underline{20 \%}$ dos sem universidades já estariam realizando sonhos ou seja tentando se formar ou ao menos se integrar nessa sociedade que exclui daqueles que não tem nome nem dólares em sua conta." (15 a 36).

\section{Enunciados presentes em D330:}

R: "Eu penso que o governo com o poder que ele tem, de poder mandar as situações ao invés tem ter o credito educativo, deveria pressionar as universidades particulares a diminuir suas mensalidades, ao um valor a que todas as pessoas pudessem, pagar mesmo porque todos nos sabemos que a universidade particular, como entidade filantrópica, não paga impostos que uma empresa paga, tendo assim um lucro muito grande, com suas mensalidades digamos assim altas. (1 24 a 35). 
Enunciados presentes em D326:

R: "Muitas faculdades só aprova pessoa que tiveram notas altas, por mais que a pessoa se esforce eles não dão oportunidade, mas devíamos ter um processo seletivo igual para todos você não tem que ser o poderoso saber todas as matérias ponta a ponta para fazer uma faculdade, mas também você não pode saber de nada, você tem que ser regular saber de tudo um pouco.

No caso da prova do ENEM ela é totalmente diferente de uma prova de vestibular a prova do ENEM testa o seu aprendizado e o objetivo é diferentes.

Discordo em termos de você ter que pagar a taxa de inscrição, e no caso de você não passar ter que pagar novamente o mesmo valor, ou mais alto.” (1 8 a 24)

Enunciados presentes em D320:

$\mathrm{R}$ : "Referente a todos esses programas criados, tais como ENEM (Exame Nacional do Ensino Médio) e o PAS (Programa de Avaliação Seriada), acredito que esses tem diferentes perspectivas, por possuírem objetivos diferentes.

Mas porém o ENEM possa vir a ser útil em todos os sentidos, você pode não só testar seus conhecimentos adquiridos como também somar pontos que o ajudariam no vestibular."'(1 13 a 22).

Enunciados presentes em D290:

R: "Precisamos de oportunidade e de muita força de vontade.

Nós negros vivemos num mundo totalmente errado porque tudo é controlado e assim todos acabam se revoltando e desistindo de tentar." (1 20 a 25).

Enunciados presentes em D263:

R: "No texto 1, fala sobre desigualdade e injustiça, concordo plenamente com o texto, este fato de vestibular é muito complicado, direitos igual para todos, $50 \%$ de vagas para escolas públicas e 50\% de vagas para particulares. Deve haver sim vestibular, mas com justiça para nós estudantes.” (1 1 a 5 ).

Exercícios presentes em D245: 
R: “A má distribuição econômica pode ser a causa de tantas diferenças, mas, se ninguém tenta caminhar e crescer, este país já está vendido aos filhos e aos profissionais do capital. Direitos iguais, para negros e brancos, pobre e rico, estrangeiro ou natural do país.” (1 43 a 49).

Enunciados presentes em D224:

R: "Mas a verdade é que precisamos ambas partes se conscientizar que desta forma o Brasil não cresce e cada dia piora a condição de vida dos Brasileiros, trazendo menos desenvolvimento e pessoas com menos capacidades de desenvolver em seus futuros.

$\mathrm{Na}$ verdade os nossos governantes querem gente assim para poder ganhar voto porque filho obedece pai e mãe de criação, então eles criam assim um mundo fechado que o é fácil e mais aproveitável pra que ir contra seu pai. Na verdade isso é medo de não serem jogados no lixo mas deveríamos mostrar que somos capaz de mudar esse país que tem tudo para ser melhor e eles facilitando o acesso a faculdades, fazendo faculdades próximas de pessoas de baixa renda e facilitando em meio de transporte livros mais econômicos." (124 a 41).

Enunciados presentes em D353:

R: "Realmente fico chatiada, quando o assunto é faculdade e universidade, porque a maioria de nós jovens, sonhamos em fazer faculdade e vencer na vida. Mas para vencer na vida tem que batalhar, pois nem tudo é de graça, ainda mais quando não se tem emprego e as coisas dificultam cada vez mais.

Tenho medo do futuro, das novas gerações que virão, pois se atualmente está difícil, imagine daqui pra frente." (126 a 37).

Enunciados presentes em D359:

"Pois o acesso a universidade é um direito de todos que o desejam e dever do poder público abrir perspectivas de novos horizontes para as pessoas que querem uma Boa qualificação que lhes garantam o futuro mais tarde." (137 a 40).

Enunciados presentes em D89: 
R: "Por isso, independente de um sistema de cotas ou não, devemos lutar por um sistema de ensino que funcione e atenda às necessidades do povo de baixa renda: a grande maioria do povo brasileiro.” (1 52 a 60).

Enunciados presentes em D71:

Q1: “O problema do negro no Brasil é bem visível, por que ele é discriminado, por ser negro. Portanto, os filhos dos escravos são excluídos e isso foi o que herdaram. "Nunca o Brasil corrigiu o crime que cometeu contra os negros."

Enunciados presentes em D91:

R: "Merecemos também fazer uma faculdade, merecemos um bom emprego, merecemos dignidade...

E é por essa razão que estamos aqui hoje tentando, lutando para lá na frente poder olhar para trás e dizer a nós mesmo que conseguimos, vencemos, lutamos e batalhamos para ter o que conseguimos...

Nossa dignidade...”(1 45 a 51).

Enunciados presentes em D101:

R: "Digo isso por mim, pois terminei o ensino médio, estou correndo atrás de um emprego para conseguir pagar a mensalidade da Universidade. Lembrando que não sou um caso isolado.

Muitos estudantes da Rede chance Reduzida de entrar em uma USP, PUC, unicamp. Não por falta de mérito mais sim por condições sociais." (1 13 a 18)

"Como um país como o nosso Brasil grande e farto de todas as riquezas pode ainda existir discriminação contra o negro, o pobre, o mal vestido, ao deficiente e contra o próximo." (1 27 a 30).

Enunciados presentes em D246:

R: "Já o aluno da rede pública não tem todo esse incentivo, essa força de vontade e principalmente tempo; primeiro por que ele fica com pensamentos na cabeça do tipo: 'Ah... se meus pais e meus irmãos não fizeram faculdade, porque eu vou fazer?' Isso prejudica muito; não são todos que tem este tipo de pensamento, há alguns com 
força de vontade que lutam pelos seus objetivos; como eu estou há 2 anos lutando pelo ingresso em uma universidade e ainda não consegui, mas já pensou se todos pensassem assim? Não é certo.” (1 13 a 23)

"Enfim, as universidades não deveriam mais ter vestibular, ou que pelo menos facilitasse o seu ingresso. Milhares de pessoas tem o sonho de ser alguém na vida, poucos são os "sortudos", e tudo isso graças a ignorância da sociedade que não enxerga o mal que está fazendo à sua pátria. Se todos nos dessem uma chance, o Brasil estaria bem melhor, talvez até um dos melhores na lista da educação. Mas, não vamos desistir, pois o futuro nos pertence." (145 a 54).

Enunciados presentes em D318:

R: "Estamos só no começo de uma nova fase no ensino brasileiro. São com pequenas iniciativas que poderemos mais tarde colher grandes frutos." (137 a 41).

Enunciados presentes em D300:

R: "Temos que lutar agora, pelos nossos direitos, não é porque nascemos pobre, temos que morrer sem conhecimentos ou uma faculdade que tanto queremos. Não podemos deixar nossos sonhos morrer, temos que acreditar nos nossos políticos, não abaixarmos nossa cabeça e sim levanta-la e irmos em frente. Temos que acreditar que venceremos a desigualdade e a injustiça e que o pobre também pode ser doutor." (1 46 a $55)$.

Enunciados presentes em D257:

R: "As universidades deveriam fornecer uma quantidade de vagas que garanta o acesso direto para os alunos de escolas públicas e é claro que, esta venha atender as necessidades de sua população.

Existem uma série de propostas para atender a população mais carente, mas, infelismente ainda não fomos beneficiados pois elas não foram concretizadas, o que significa que, por mais algum tempo teremos que conviver com os ricos ocupando o nosso lugar nas universidades públicas.

Temos que lutar pelos nossos objetivos, e a universidade pública, também é um direito da população de baixa renda, então vamos lutar por ele, para futuramente disser: eu venci na vida. 
Assim como os "filhinhos de papai" também queremos ampliar os nossos conhecimentos e a nossa perspectiva de vida, enfim, podermos progredir cada vez mais, mas de que maneira se nem a faculdade temos acesso?"(124 a 43).

Enunciados presentes em D83:

"As pessoas devem dar mais importância ao que se passa com a nossa educação do que se passa com a mídia, promover passeatas e protestos e se veicular no nosso meio de transporte mais poderoso e de acesso à todas que é a televisão do que darem espaço em horário nobre para se promover a violência e o sexo dentro dos lares.

A sociedade tem que concordar e perceber que se nós não mudarmos este país e fazermos por onde melhorar a nossa vida ninguém vai fazer por nós, então vamos descruzar os braços e fazer um mundo melhor." (1 51 a 60).

\section{Enunciados presentes em D31:}

R: "Se lutasemos mais por essa causa de uma faculdade para todos com certeza conseguiremos ter certo resultado, afinal "água mole em pedra dura tanto bate até que fura"”. (136 a 39).

Enunciados presentes em D32:

$\mathrm{R}$ : "O direito ao acesso a universidade no Brasil ainda é muito restrito. Mas se todos lutarem por esse direito muitas coisas podem melhorar." (1 38 a 40).

Enunciados presentes em D49:

R: "Enquanto isso o aluno pobre, negro, fica sem apoio, do estados, do próprio governo e deputados para quem votaram, sei que existem exceções, mas... esta é uma realidade do Brasil, século 21 ano 2003, o Brasil de ontem e hoje.

O que nos resta é lutar, e não perder as esperanças ou poderia dizer as "estribeiras".

Porque essa é uma característica do povo brasileiro, que está no sangue, mas nem sempre está, no sangue daquele que governa, e no que tem poder de mudar e melhorar, não só o estudo, como também a educação, desemprego etc.” (136 a 48).

Enunciados presentes em D44: 
R: "Portanto se a sociedade quiser defender o direito de acesso à universidade no Brasil terá que lutar por projetos que consigam assimilar esses itens citados e não se acomodar com as diferenças sociais do país e sempre fazer o possível para melhorar." (1 28 a 34$)$.

Enunciados presentes em D42:

R: "Há um grande desejo em mudar essa situação, em ver todo cidadão brasileiro exercendo seus direitos e sendo tratados da mesma forma, mas não basta somente querer, tem que haver uma união entre o querer e fazer, temos que concientizar e principalmente o governo deve se conscientizar e lutar pra que nesse país haja igualdade à todos para que um dia nós possamos nos orgulhar de nossa vida e deixar um mundo melhor para nossos filhos." (137 a 45).

Enunciados presentes em D86:

R: "Portanto se os jovens se unirem e lutarem por seus direitos e espaço na sociedade, irão obter um bom resultado." (1 42 a 44).

\section{Enunciados presentes em D35:}

R: "Mas, com o objetivo de que esse quadro mude e com a boa vontade dos governadores, com a luta das entidades e movimentos deem incentivo, possam ajudar nós jovens de baixa renda dando oportunidade através desse cursinho pré-vestibular, estarmos tentando um acesso em universidades públicas, por que todos nós jovens temos o direito de acesso a elas e conseguimos nos tornar-se profissionais qualificados, em profissões em que achamos maior identificação com os nossos perfis e caminharmos em frente para que o nosso país também caminhe rumo a igualdade social, e se os governadores derem andamento nesses projetos e incentivarem os movimentos e entidades logo, logo estaremos concretizando os nossos desejos e muitos outros jovens de outras gerações também, mas, para isso deveremos lutar mais e mais e mais. " (1 26 a $45)$.

\section{Enunciados presentes em D1:}

R: "Se as opiniões e idéias deixasem de estar apenas em papéis, documentos, e virarem realidade, quem sebe assim, conseguiremos pelo menos $40 \%$ de vagas em universidades para a população de renda baixa." (1 44 a 50). 


\section{Enunciados presentes em D323:}

R: "Digo isso por mim, pois terminei o ensino médio, estou correndo atrás de um emprego para conseguir pagar a mensalidade da Universidade. Lembrando que não sou um caso isolado.

Muitos estudantes da Rede chance Reduzida de entrar em uma USP, PUC, unicamp. Não por falta de mérito mais sim por condições sociais.” (113 a 18).

... "Como um país como o nosso Brasil grande e farto de todas as riquezas pode ainda existir discriminação contra o negro, o pobre, o mal vestido, ao deficiente e contra o próximo." (127 ao 30).

\subsection{A imbricação entre os discursos fragmentados dos novíssimos sujeitos sociais e uma instituição de direito coletivo difuso no Brasil: o MSU, Movimento dos Sem Universidade, constituindo-se assim um novíssimo movimento social.}

A imbricação entre um discurso e uma instituição é condição de existência do próprio discurso publicamente e de sua inscrição na história. Por isso, é possível sim falar em imbricação real entre as reivindicações dos novíssimos sujeitos sociais fragmentários na luta pelo direito à universidade no Brasil, se e somente se, a instituição, o MSU no caso, tenha identidade discursiva, ao menos, com as reivindicações desses homens e mulheres, esses novíssimos sujeitos sociais, bem como a capacidade mínima de levar esse discurso, dar-lhe a devida visibilidade, para a cena pública, no sentido de alterar as condições objetivas do acesso à universidade no Brasil.

Para tanto, desde esse enraizamento popular inscrito na história do Brasil terá que emergir publicamente o discurso do MSU.

Nesse ponto, a prática discursiva do MSU deverá estar sintonizada, senão com todos os possíveis discursos e reivindicações dos novíssimos sujeitos sociais, ao menos com parcelas desses discursos. 
Outrossim, a instituição deverá eleger prioridades, bandeiras e estabelecer negociações discursivas para que o discurso do MSU tenha emergência na sociedade brasileira como fruto de um consenso de baixo para cima, mas capaz de empolgar e mobilizar os Sem Universidade, esses novíssimos sujeitos sociais e ir para a arena pública disputar políticas públicas.

Nos marcos dessa dissertação, poucos índices discursivos, mas que no entanto, a própria discussão teórico-analítico-empirica abriga, são suficientes para a confirmação da emergência do discurso do MSU no Brasil, tomando-se como critério complementar o próprio desenrolar histórico e as consequências efetivas dessa emergência, que por tabela, dá legitimidade ao próprio MSU.

Assim, no curso dessa emergência discursiva do MSU, cabe apontar, alguns indícios muito fortes:

1. A luta por isenções das taxas dos vestibulares.

2. A luta pela criação de novas universidades públicas.

3. A luta pela criação de um sistema público nacional de bolsas de estudos em instituições privadas, O PROUNI.

4. A luta pela reserva de $50 \%$ de vagas, ao menos, por turno e por curso, para estudantes oriundos da escola pública, negros, indígenas e de baixa renda nas universidades públicas ou Luta pela Lei de Cotas.

5. A luta pela transformação do ENEM em critério de acesso à universidade.

6. A luta pela criação de conselhos sociais nas políticas de educação.

Esses índices discursivos mínimos e sua presença real na história do Brasil indiciam fortemente o fito principal dessa dissertação, ou seja, a identificação da EMERGÊNCIA DO DISCURSO DOS SEM UNIVERSIDADE, DO MSU, NO BRASIL de forma legítima.. 


\subsection{O discurso dos Sem Universidade ganha a rua, o parlamento, o espaço público}

Para um registro simples da competência discursiva ampliada MAINGUENEAU (2005) avançou para além dos textos e buscou interpretar os discursos presentes em quadros de pintores selecionados pertinentes para a identificação do discurso jansenista ou humanista devoto, na toada do interdiscurso.

No presente estudo, o discurso dos Sem Universidade aparece também em outros nichos semânticos, que complementarmente, enriquecem este estudo à medida que simbolicamente indicam momentos relevantes em que a luta por direitos ganha uma cenografia pública e mesmo, transforma-se em políticas, o que era um urgente grito, como visto ao longo da dissertação, transforma-se em direitos garantidos na letra da lei. Por isso, pode-se falar em ampliação da cena discursiva dos Sem Universidade no Brasil e mais, em novas mediações epistêmicas e novas responsabilidades discursivas, eminentemente coletivas, cujas vitórias obtidas em termos de alterações nas políticas de democratização do acesso à universidade do Brasil servem como prova ou materialidade da própria emergência do discurso dos Sem Universidade, do MSU e seu sentido mais pedestre..

As novas mediações epistêmicas, no limite das cenas públicas, como o longo período de tempo para a aprovação da Lei de Cotas (2005-2012, ao menos, desde o acordo patrocinado pelo MSU na Comissão de Educação da Câmara dos Deputados em torno do PL 73/99); os rituais fechados e regimentais do parlamento brasileiro; a força do discurso da /ORDEM/; a polícia; a assimetria dos recursos entre os contundentes. Nessa leitura, a mediação epistêmica ganha nova potência, não é mais mediação apenas para um papel em branco: é disputa real pela aprovação da Lei de Cotas e afins, nas arenas do poder legislativo, judiciário e executivo, no âmbito nacional. Neste cenário maior, muitas análises ficam aqui para outras pesquisas.

De igual modo, novas responsabilidades discursivas surgem para os sujeitos assumirem ou não, assujeitarem-se ou não. É uma espécie de teste de fogo de uma responsabilidade discursiva coletiva, enquanto aquela dos documentos tinha uma matriz de formulação individual, esta outra necessariamente precisa enunciar seu discurso com responsabilidade na cena pública, sob o crivo e a disposição para o julgamento público. 
Esse passo foi dado com coragem, um salto mortal na cidadania brasileira: quando a responsabilidade de um somatório de novíssimos sujeitos sociais isolados no microcosmo das grandes periferias urbanas transforma-se numa causa pública comum no macrocosmo: a luta pelo direito à universidade no Brasil. São provas incontestes destes movimentos os registros documentais destas institucionalidades ou arenas de disputa por políticas, caso dos anais do Congresso Nacional do Brasil, de igual modo, chão para pesquisas. Com parcos e assimétricos recursos, o discurso público dos Sem Universidade arrancou notáveis vitórias que contribuíram para alterar parcialmente a realidade brasileira do acesso à universidade. Mesmo que engolidos, sufocados e submergidos pela potência discursiva da propaganda oficial do Estado e suas mil e uma estratégias discursivas, no DNA de políticas como o PROUNI, o ENEM como critério de acesso à Universidade, a criação de novas universidades públicas, como a UFABC e a aprovação da Universidade da Cidade e da Cidadania no Município de São Paulo em 2002, as isenções das taxas, e de modo decisivo a aprovação da Lei de Cotas no Congresso Nacional (Lei 12.711/12), nessas políticas, diga-se sem medo, estão o DNA do discurso dos Sem Universidade no Brasil, do MSU..

As cenas públicas abaixo indicam a presença na sociedade brasileira do discurso dos Sem Universidade, sustentado argumentativa as hipóteses colocadas para essa investigação..

A proposta foi apresentada pelo MSU em 2002 foi em ato simbólico. A entrega do texto foi realizada por um Sem-Universidade vestido de beca e outro de presidiário, chamando a atenção para o clamor da periferia de São Paulo pelo direito à universidade, para a necessidade do Carandiru virar universidade.

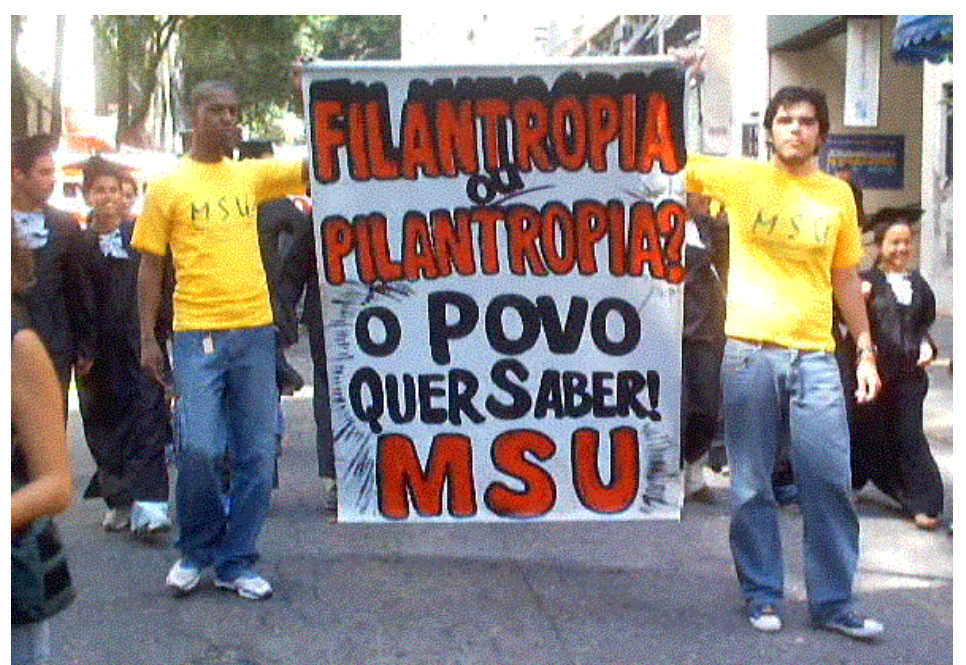


MSU Protocolou representação no Ministério Público Federal de São Paulo contra as Universidades Filantrópicas, exigindo $20 \%$ de Bolsas de Estudo, através da regulamentação da Lei da Filantropia, coordenada pelo conselho nacional de assistência social. A Representação $\mathbf{N}^{\circ}$ 1.34.001.002090/2004-61. Autuada pela Procuradoria da República em 30/04/2004. Esta luta conquistaria o ProUni.

\section{EDUCAÇÃO}

Entidade faz protesto contra Mackenzie e entra na Justiça contra filantrópicas Cerca de cem integrantes do Movimento dos Sem-Universidade (MSU) fizeram um protesto ontem de manhã em frente à Universidade Presbiteriana Mackenzie. Eles questionaram o caráter filantrópico atribuído a certas instituições de ensino superior, adotando o slogan: "Filantropia ou Pilantropia?".

O movimento acusou as universidades filantrópicas, que têm isenção fiscal, de descumprirem a contrapartida de usar $20 \%$ das receitas em bolsas de estudo ou em assistência social.

O Mackenzie nega a acusação e afirma investir mais do que o determinado pela lei. A universidade informa que só em 2003 concedeu 15 mil bolsas. O MSU entrou ontem com representação no Ministério Público contra universidades filantrópicas. O movimento solicitou ainda audiência com o ministro da Educação, Tarso Genro, e com a Comissão de Educação da Assembléia Legislativa de São Paulo. (Fonte: Folha de São Paulo - Caderno Cotidiano - 24 de Abril de 2004 ) .

O discurso do MSU aparece em outras bases semióticas, como na internet neste endereço, onde os novíssimos sujeitos sociais do Brasil, vão até Brasília protestar. https://www.youtube.com/watch?v=I01KpZD2E0U 
FIGURA 17 - CAPA DO JORNAL FOLHA DE SÃO PAULO DÁ MANCHETE À LUTA DOS SEM UNIVERSIDADE EM PROL DA ISENÇÃO DAS TAXAS COBRADAS PELAS UNIVERSIDADES PÚBLICAS PAULISTAS NO VESTIBULAR.

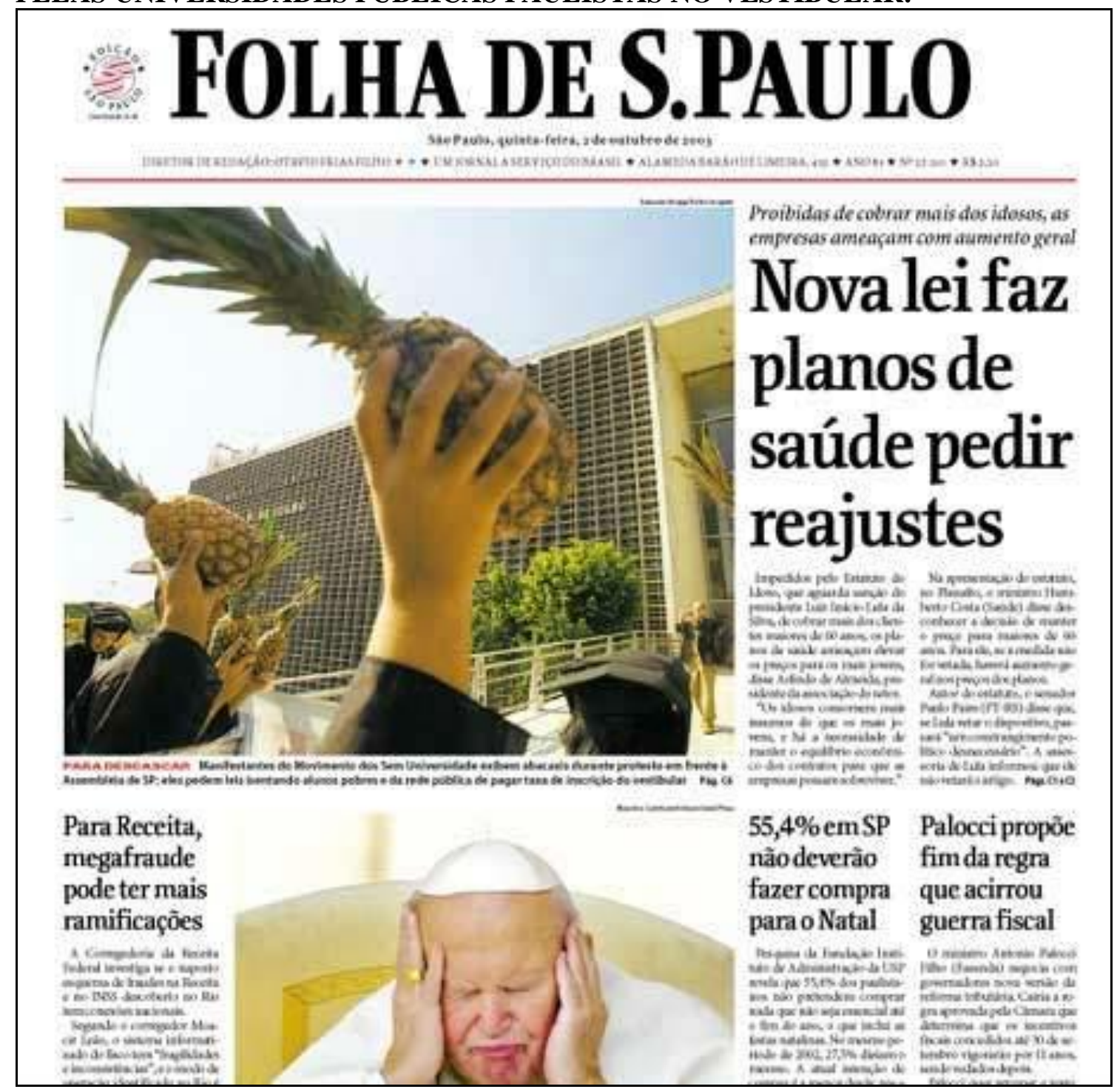

Fonte: Jornal Folha de São Paulo, dia 2 de outubro de 2003. 
FIGURA 18 - MATÉRIA DADA PELO JORNAL FOLHA DE SÃO PAULO SOBRE MANIFESTAÇÃO DO MSU NA ASSEMBLEIA LEGISLATIVA DO ESTADO DE SÃO PAULO, PELA ISENÇÃO DAS TAXAS DOS VESTIBULARES NAS UNIVERSIDADES PÚBLICAS PAULISTAS.

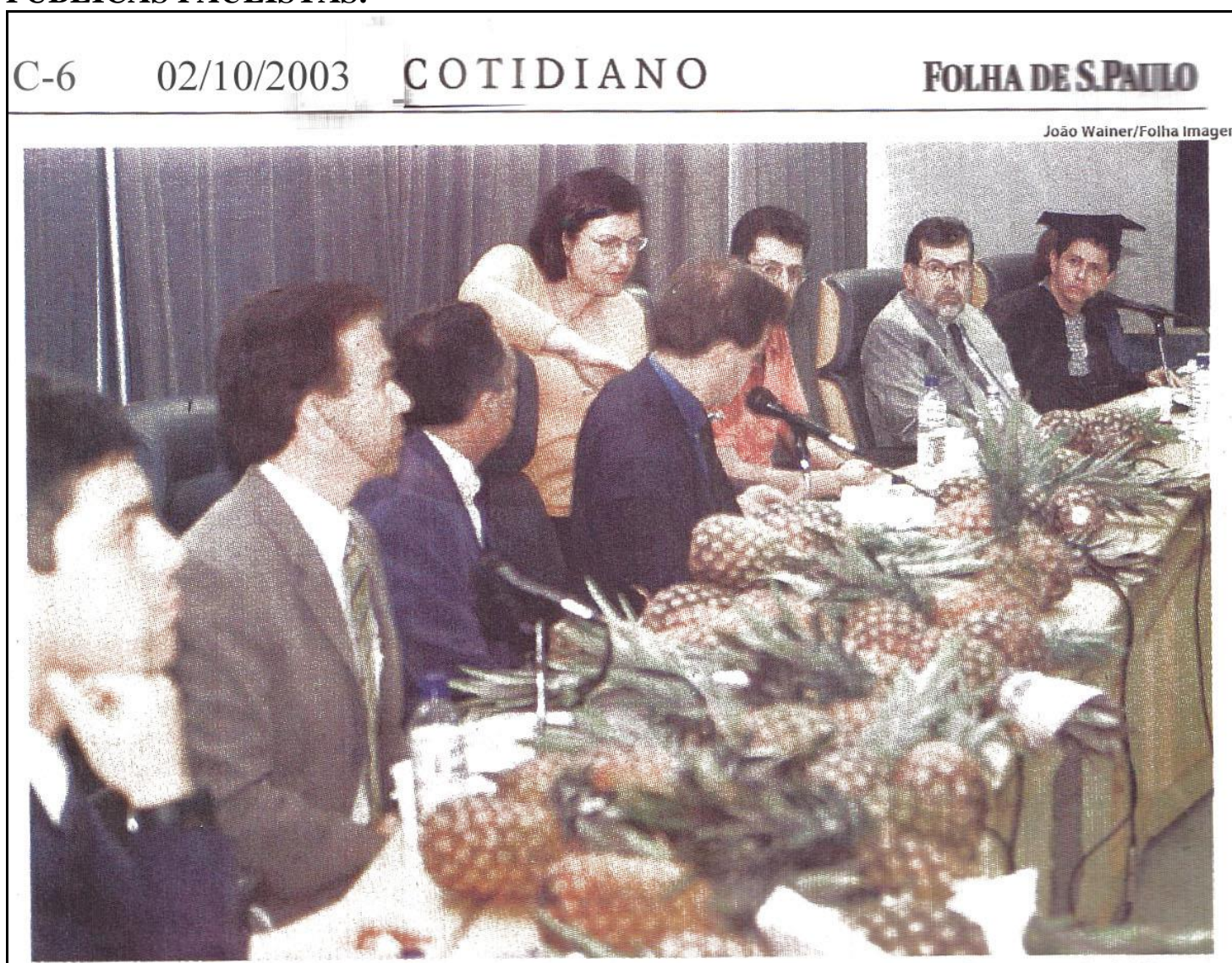

Manifestantes do Movimento dos Sem-Universidade entregam abacaxis a deputados na Assémbléia

EDUCAÇÃo Movimento distribuiu abacaxis para deputados Manifestantes pedem isenção de taxa de inscrição de vestibular

DA REPORTAGEMLOCAL

Manifestantes distribuíram na tarde de ontem abacaxis para os deputados que ingressavam no prédio da Assembléia Legislativa de São Paulo. O protesto em favor da criação de leis estaduais que isentam alunos de baixa renda $\mathrm{e}$ da rede pública das taxas de inscrição do vestibular foi realizado por 111 membros do MSU (Movimento dos Sem Universidade).

Ontem foi realizada audiência pública sobre a gratuidade das inscriçōes. Dois projetos de lei, dos deputados Waldir Agnello (PSB) e Roberto Morais (PTB), abordam o tema. "É necessário dar oportunidades para os estudantes da rede pública. Só assim eles serão estimulados a conti- nuar os estudos", diz Sérgio José Custódio, coordenador do MSU.

O presidente da comissão de educação, deputado Carlinhos Almeida (PT), disse que encaminhará ao governo uma sugestão para que sejam tomadas medidas emergenciais que atendam à reivindicação. Segundo ele, estavam na audiência cerca de 500 pessoas -o MSU diz que eram 300 .

Fonte: Jornal Folha de São Paulo 
FIGURA 19 - NOTA SOBRE REPRESENTAÇÃO DO MSU NO MINISTÉRIO PÚBLICO PAULISTA CONTRA DECISÃO DO CONSELHO ESTADUAL DE EDUCAÇÃO QUE VETOU A CRIAÇÃO DA UNIVERSIDADE MUNICIPAL DA CIDADE DE SÃ̃O PAULO, PROPOSTA APRESENTADA PELO MSU EM 2002.

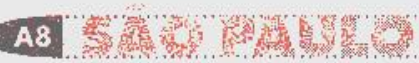

DIÁRIO PAULISTA

Pelo ensino superior

- O Movimento dos Sem-Universidade (MSU) entrou ontem com representação no Ministério Público contra o Conselho Estadual de Educação pedindo a reversão de uma decisāo do conselho que vetou a instalação de dois cursos superiores de tecnologia no bairro de Cidade Tiradentes, Com o veto, a projetada Faculdade Paulistana de Saúde Pública deu lugar à Fundação Paulistana de Educação e Tecnologia. Como argumento para derrubar o veto, - MSU cita exemplos de municipios, vizinhos à Capital, que inauguraram recentemente instituições públicas de ensino superior, com a aprovação do conselho, como Diadema, Guarulhos e Santo André. Para vetar a faculdade, o conselho afirmou que a Capital precisaria antes atender outras prioridades educacionais do ensino básico.

Fonte: O Diário de São Paulo, 2006

A proposta foi apresentada pelo MSU em 2001 foi em ato simbólico. A entrega do texto foi realizada por um Sem-Universidade vestido de beca e outro de presidiário, chamando a atenção para o clamor da periferia de São Paulo pelo direito à universidade, para a necessidade do Carandiru virar universidade. A Universidade Municipal foi aprovada na Câmara Municipal de São Paulo em 31 de dezembro de 2001 e o prédio começou a ser construído em Cidade Tiradentes em 2004 e se esparramaria por toda periferia de São Paulo: uma grande vitória da luta do MSU em 2001, 2002, 2003 e 2004. Mas a deliberação No 48/05 do Conselho Estadual de Educação do Estado de São Paulo vetou o funcionamento da Universidade pública e gratuita na periferia de Sâo Paulo. O Ministério Público não reverteu a situação até hoje. 
FIGURA 20 - ENCONTRO DO MSU NA RUA TABATINGUERA 292, QUADRA DOS BANCÁRIOS, EM 2005.

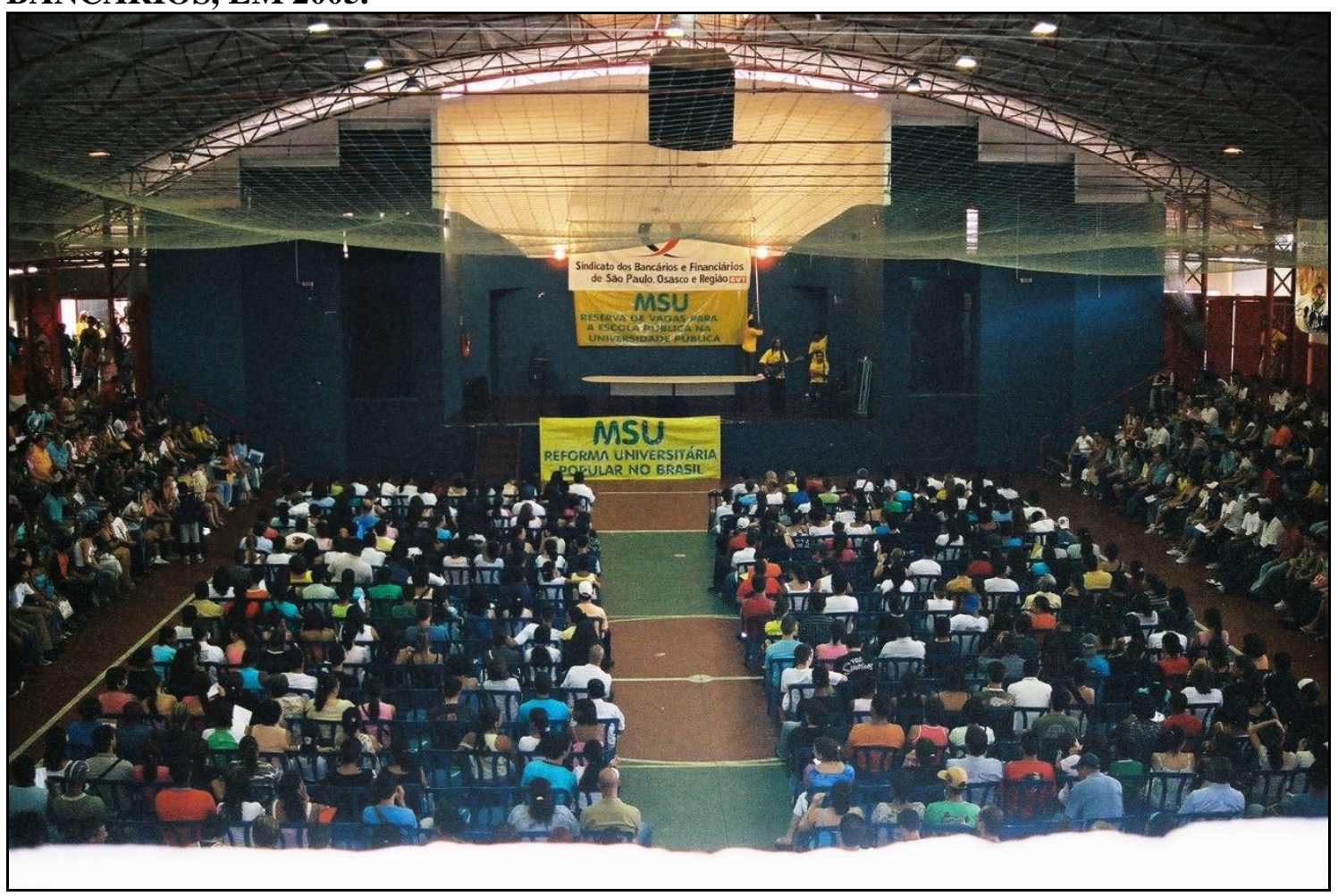

Fonte: Acervo MSU

FIGURA 21 - ENCONTRO DO MSU EM 2005: OS NOVÍSSIMOS SUJEITOS SOCIAIS.

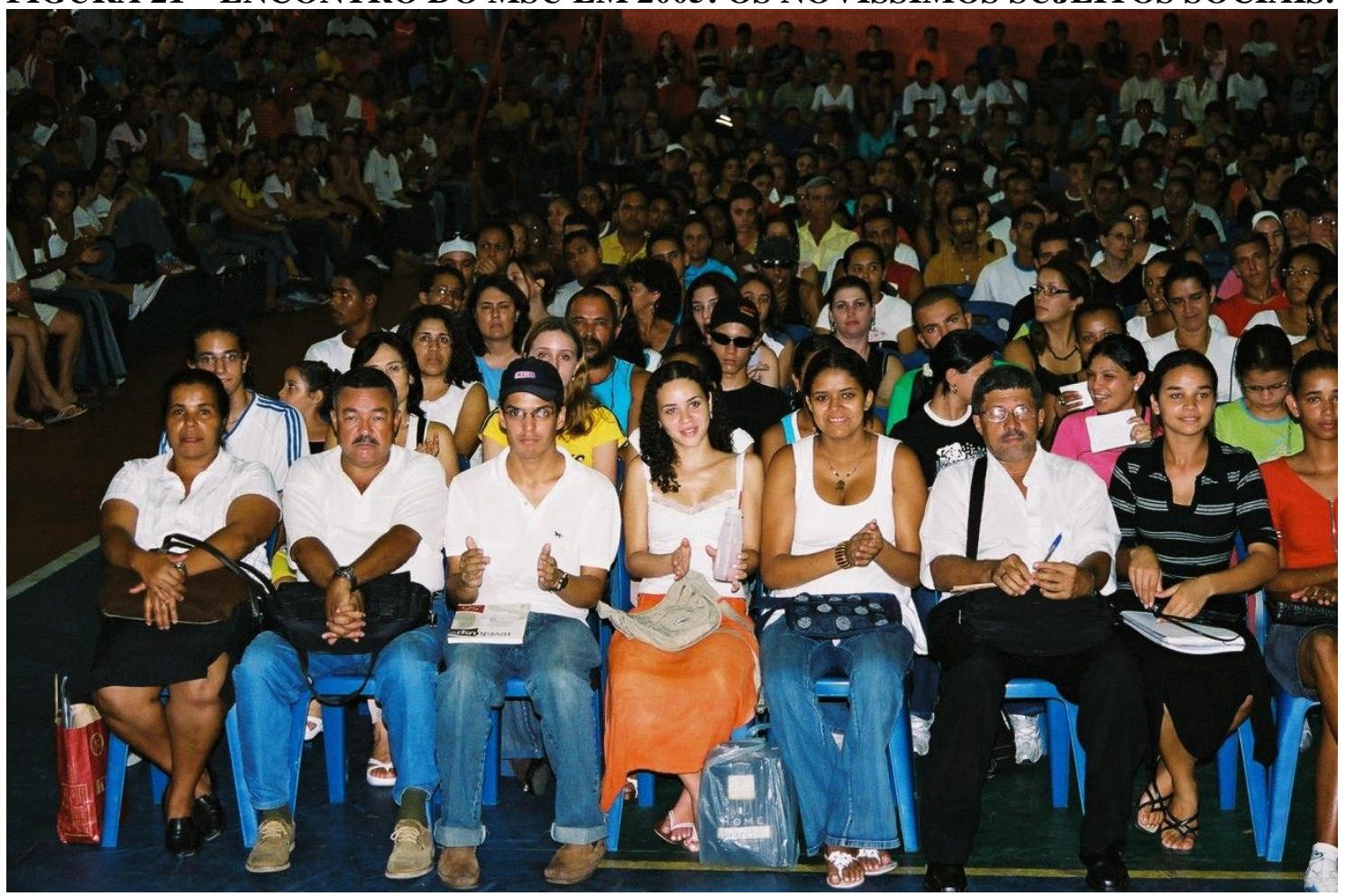

Fonte: Acervo MSU 
FIGURA 22 - ENCONTRO DO MSU EM 2005: UMA NOVA EDUCAÇÃO POPULAR NASCE NAS PERIFERIAS.

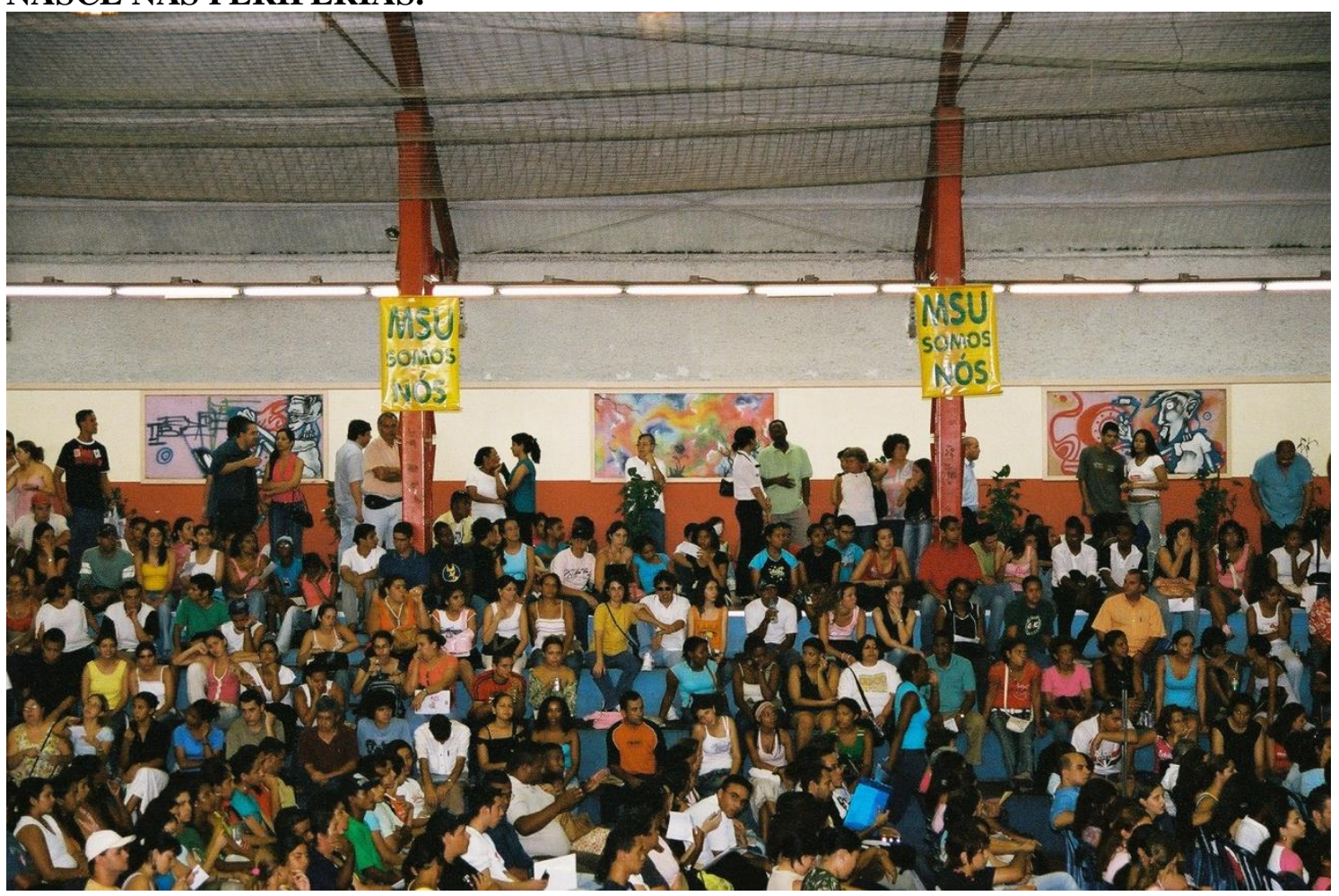

Fonte: Acervo MSU

FIGURA 23 - ENCONTRO DO MSU EM 2005: PROTAGONISMO POPULAR EM TODAS AS IDADES.

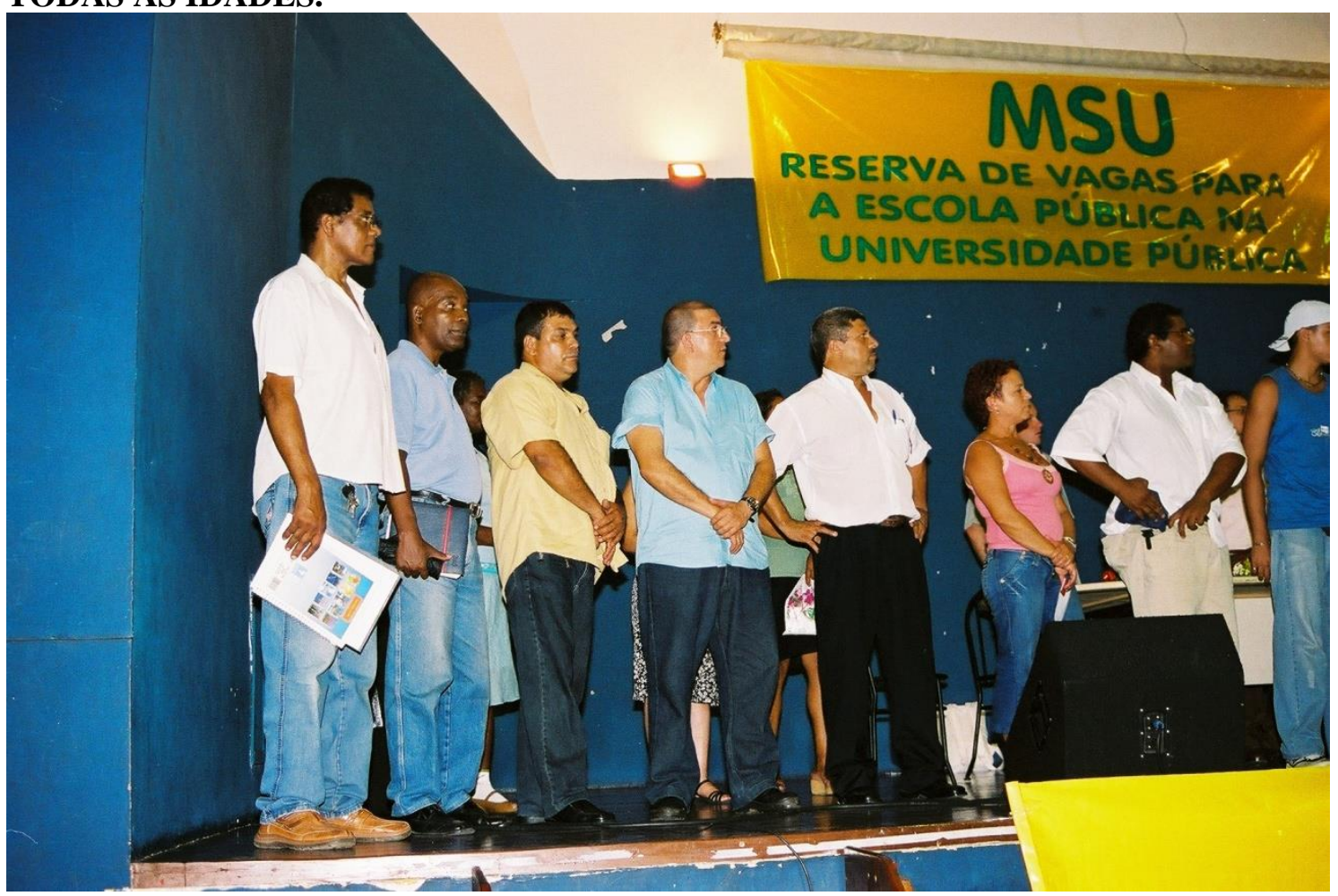

Fonte: Acervo $M S U$ 
FIGURA 24 - ENCONTRO DO MSU EM 2005: DILMA, QUE PARTICIPOU DA LUTA DOS EXCEDENTES PELO DIREITO À UNIVERSIDADE NOS ANOS 1960, ACENDE A CHAMA DA LUTA QUE PASSA DE MÃO EM MÃO NA HISTÓRIA DO MSU.

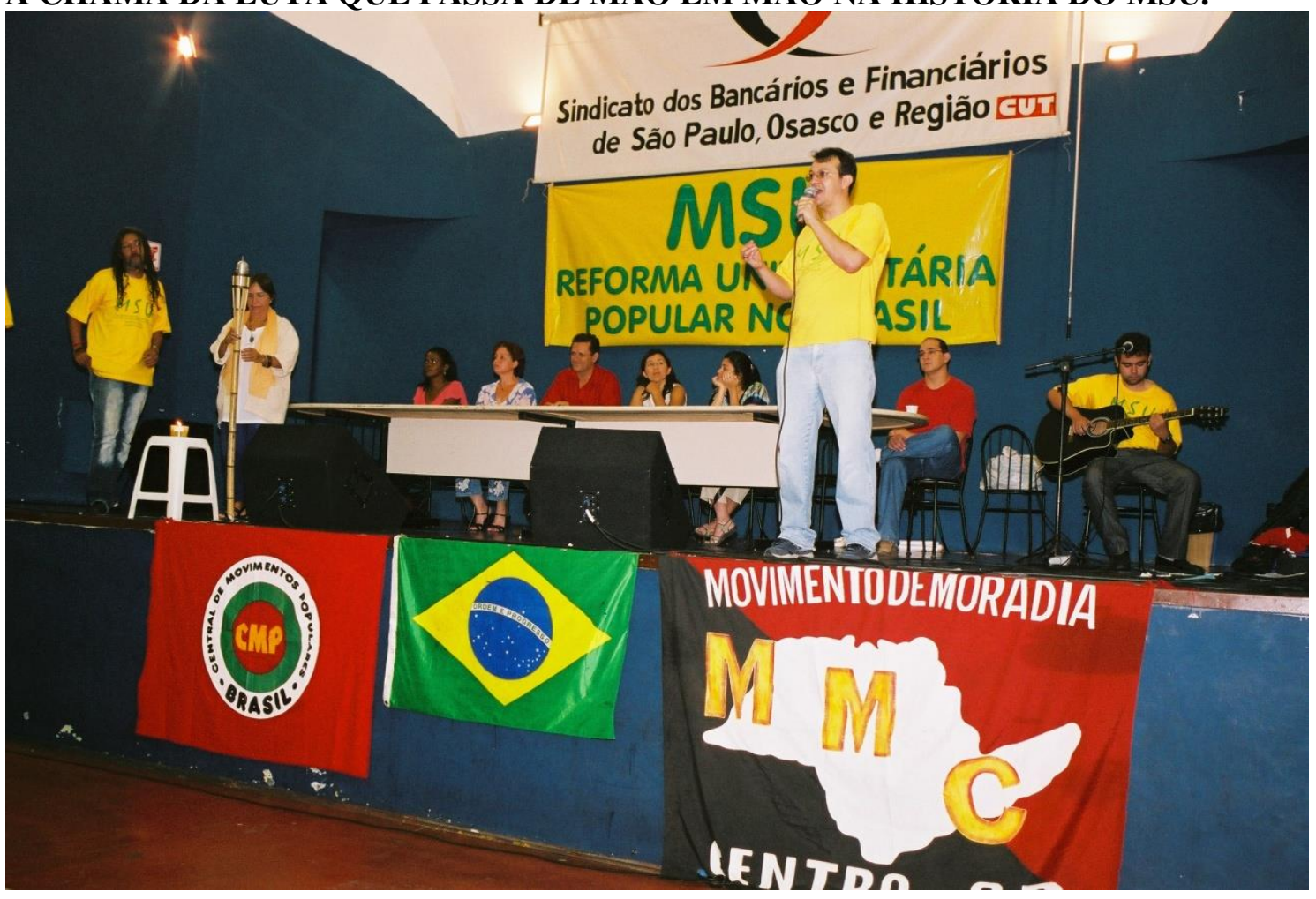

Fonte: Acervo MSU 
FIGURA 25 - ENCONTRO DO MSU EM 2005: A TOCHA ACESSA PASSA DE MÃO EM MÃO COMPARTILHANDO A RESPONSABILIDADE COLETIVA DOS NOVÍSSIMOS SUJEITO SOCIAIS.

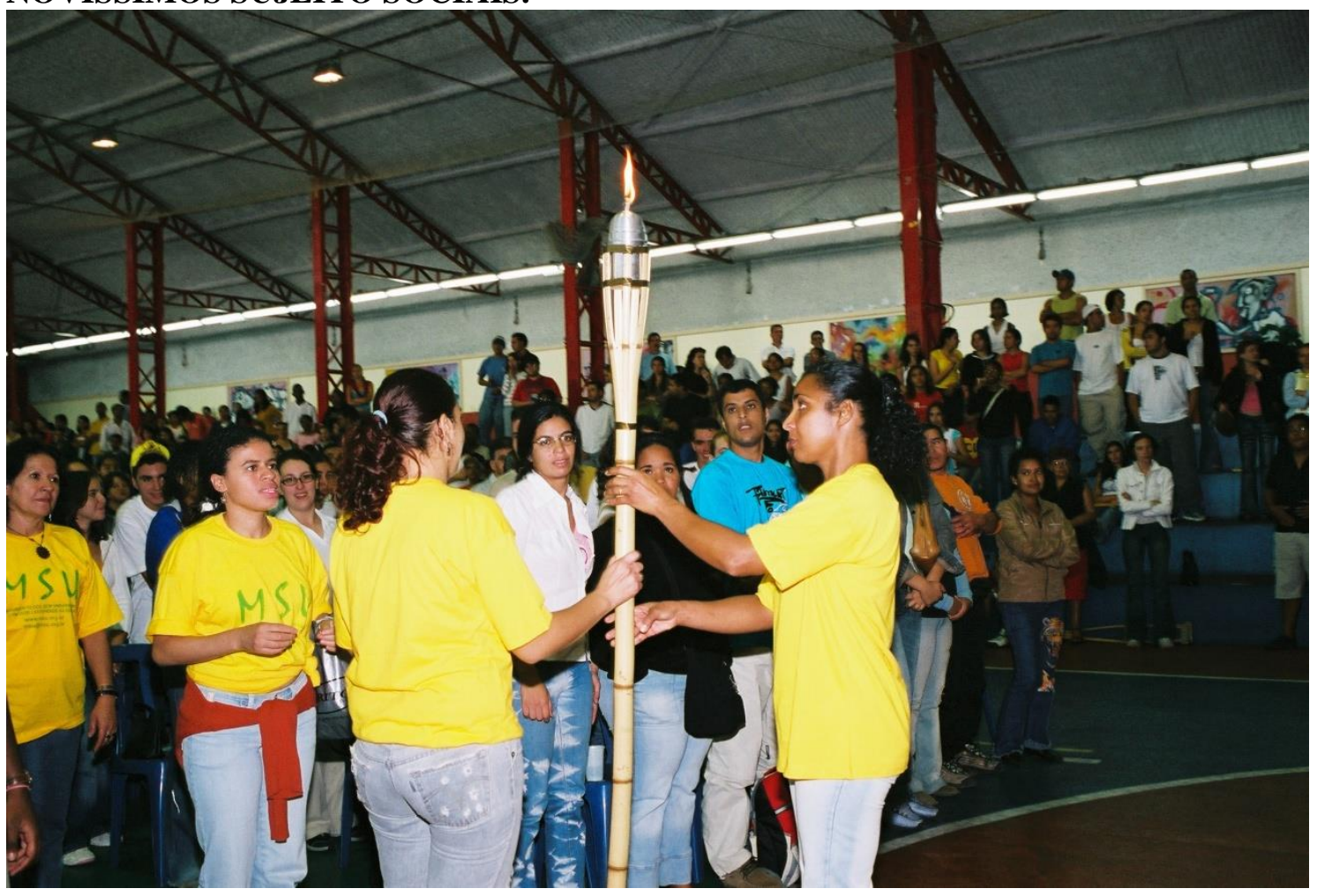

Fonte: Acervo MSU

FIGURA 26 - ENCONTRO DO MSU EM 2005: APLAUSOS PARA A TOCHA ACESA!

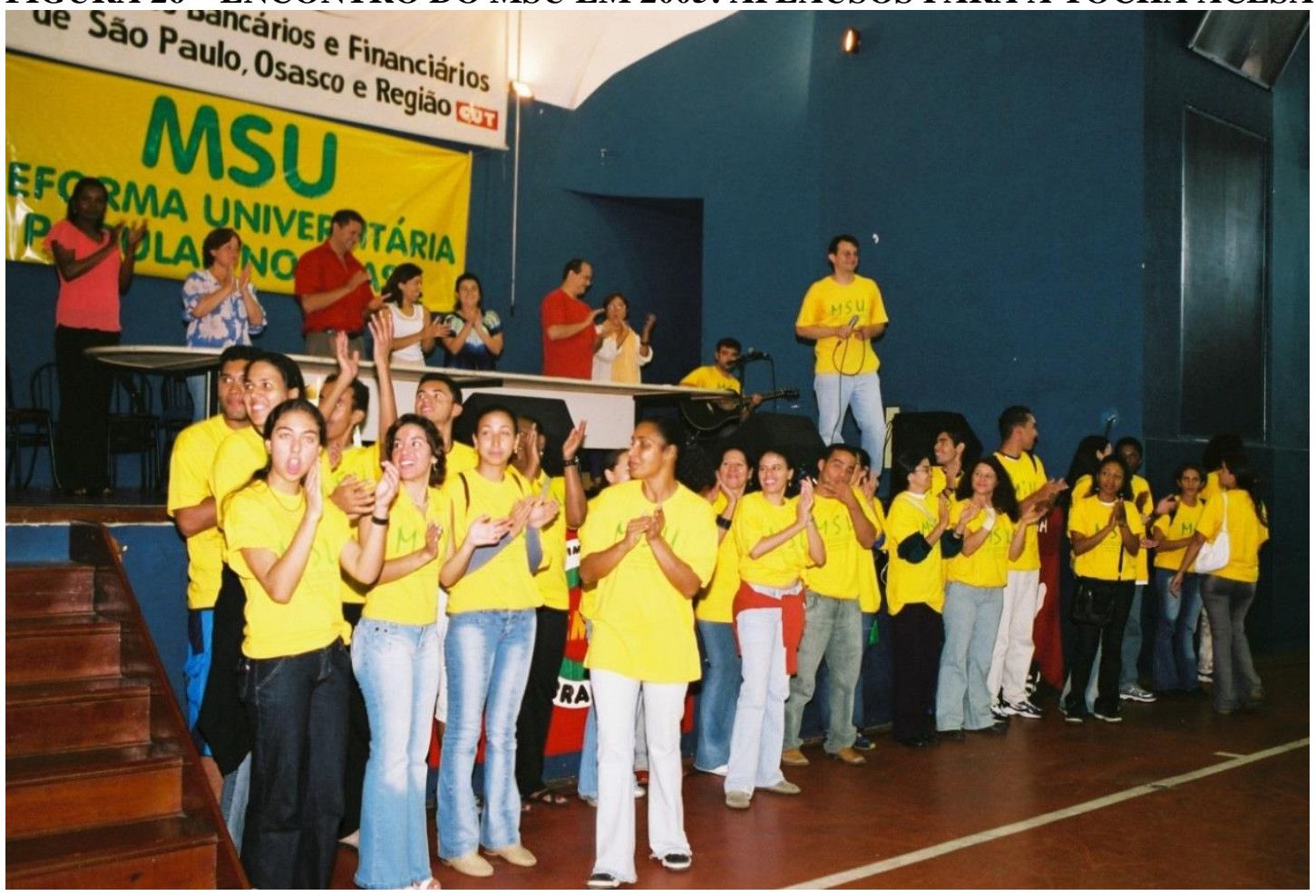

Fonte: Acervo MSU 
FIGURA 27 - ENCONTRO DO MSU EM 2005: O RECONHECIMENTO DA HERANÇA DISCURSIVA NUM BOTÃO DE FLOR ENTREGUE A DILMA.

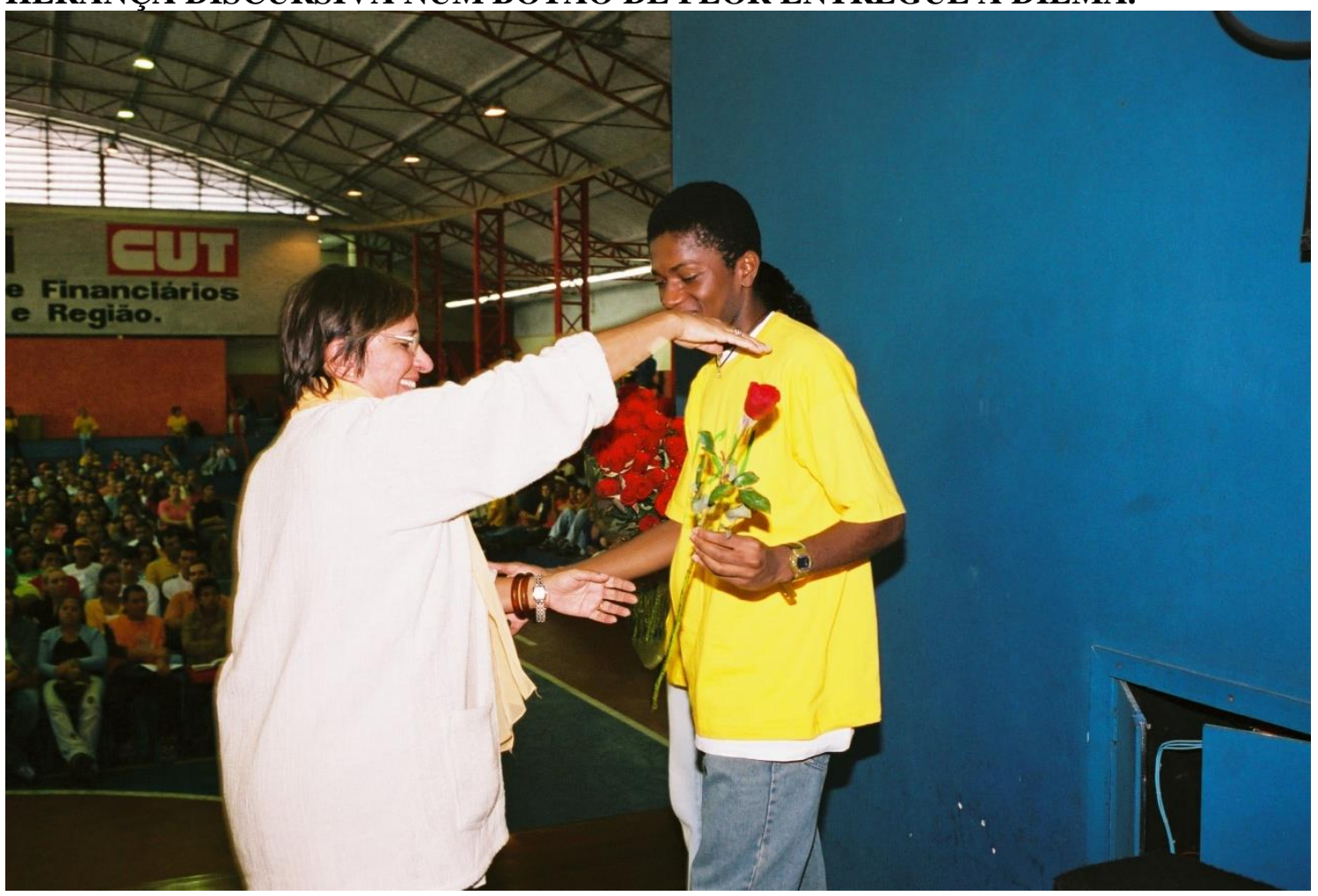

Fonte: Acervo MSU

FIGURA 28 - ENCONTRO DO MSU EM 2005: A TOCHA NO MEIO DO POVO.

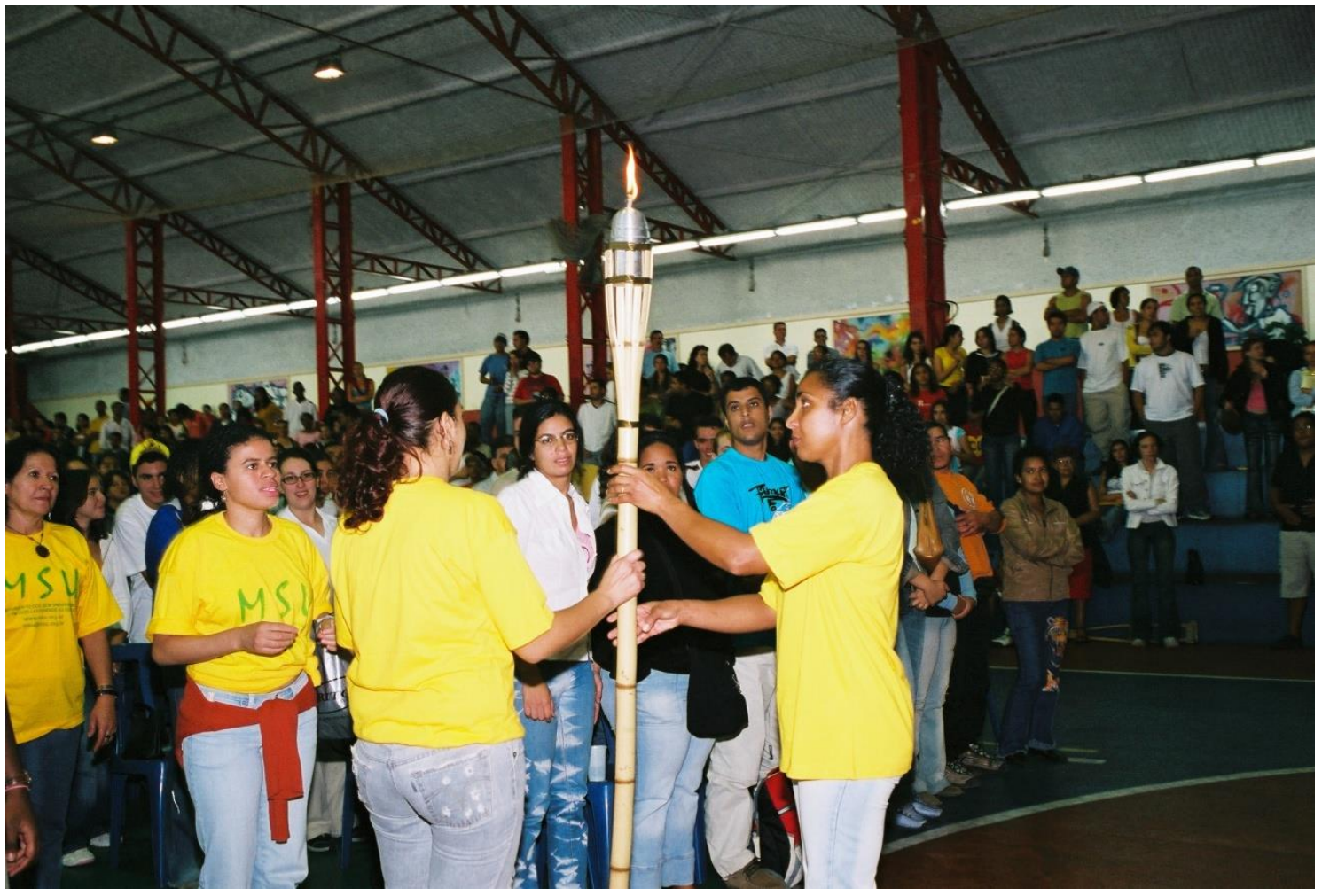

Fonte: Acervo MSU 
FIGURA 18- ENCONTRO DO MSU EM 2005: SEM VANGUARDISMO, AÇÃO EM PARCERIA SOCIAL, POIS O MSU É O SUJEITO EDUCATIVO COLETIVO.

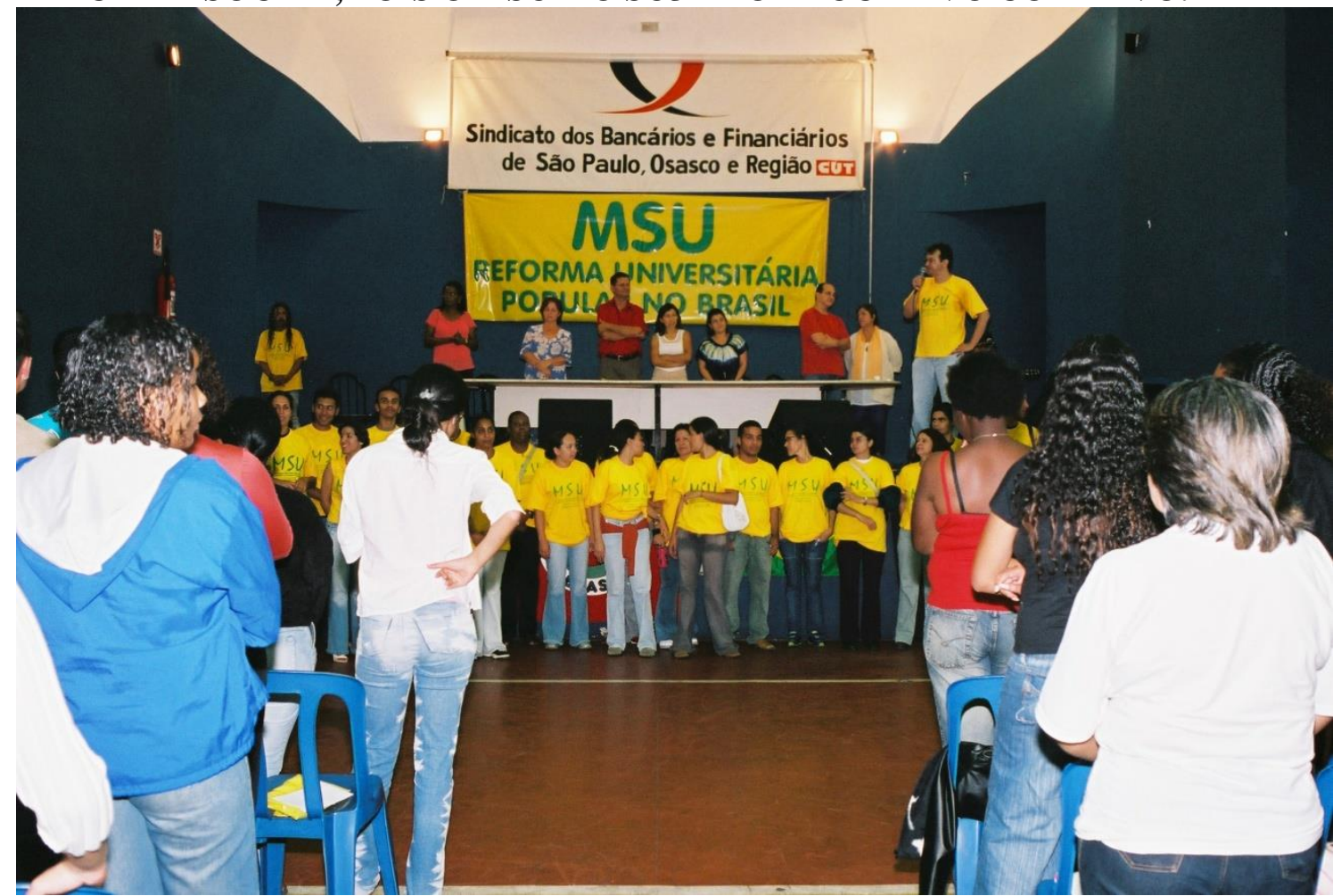

Fonte: Acervo MSU

FIGURA 29 - ENCONTRO DO MSU EM 2005: FORTE PRESENÇA POPULAR DAS FAMÍLIAS.

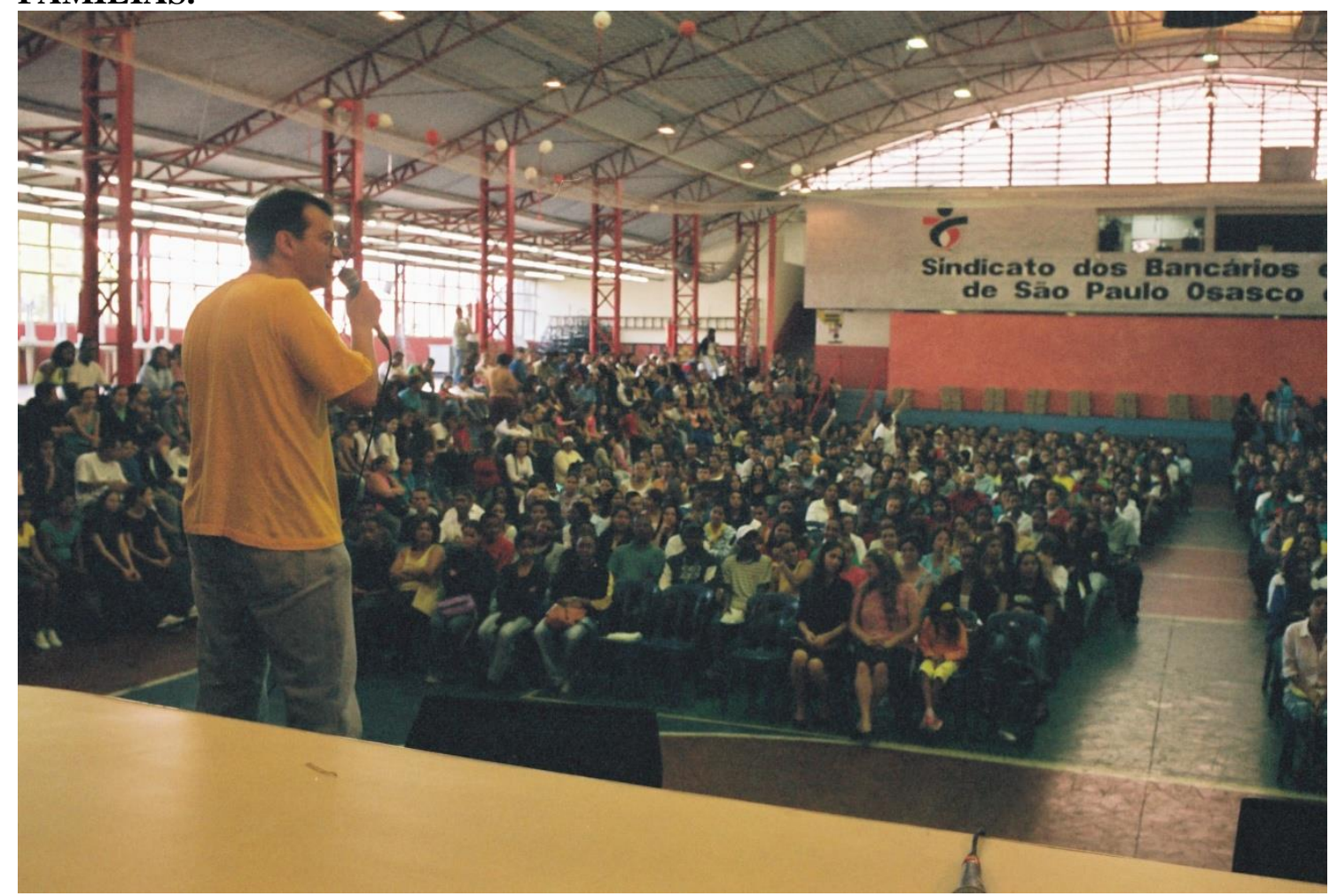

Fonte: Acervo MSU 
FIGURA 30 - ENCONTRO DO MSU EM 2005: PASSAGEM DA TOCHA E DA LUTA.

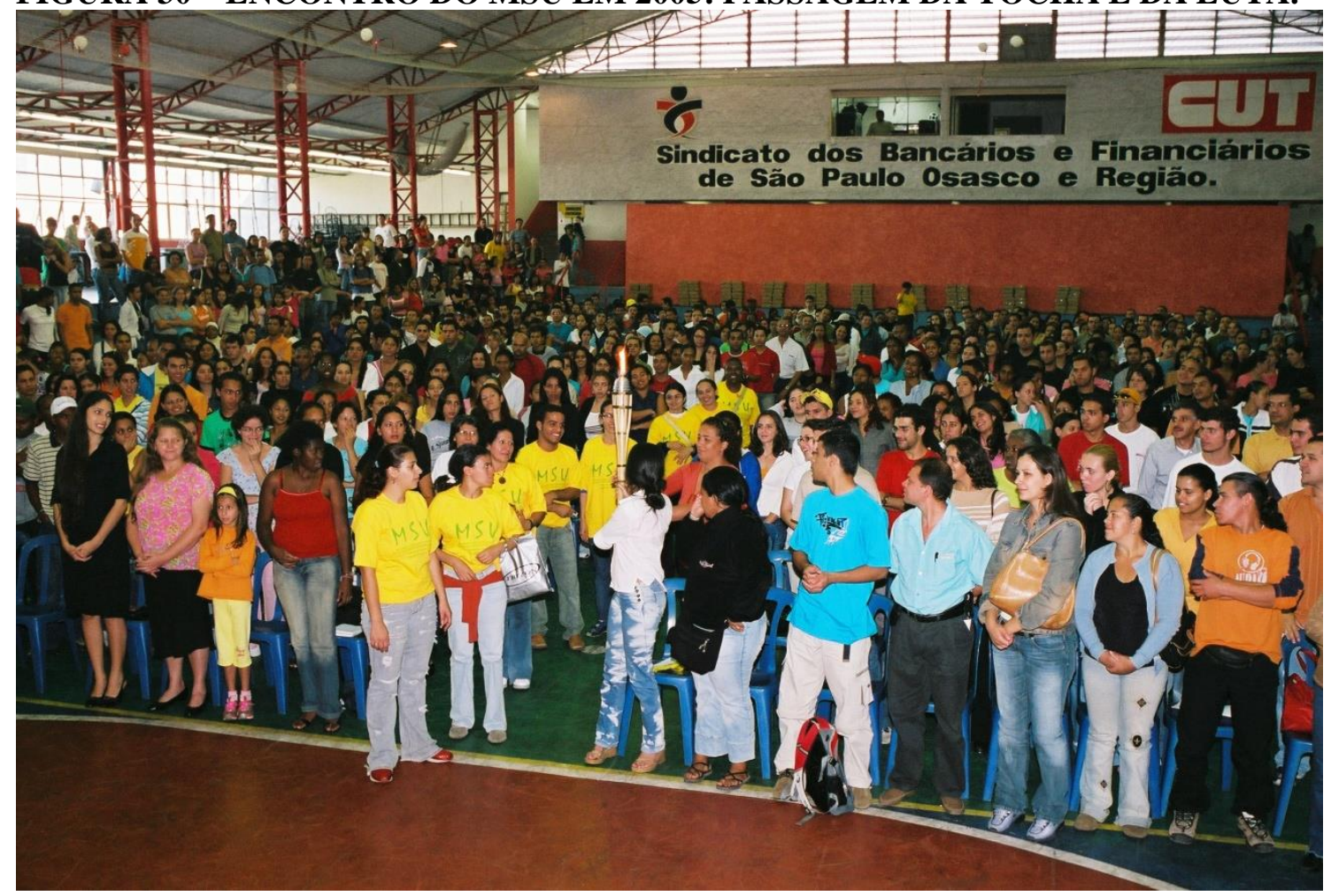

Fonte: Acervo MSU

FIGURA 31 - ENCONTRO DO MSU EM 2005: O MOMENTO DE PASSAGEM DA TOCHA DA LUTA DOS EXCEDENTES PARA A LUTA DO MSU.

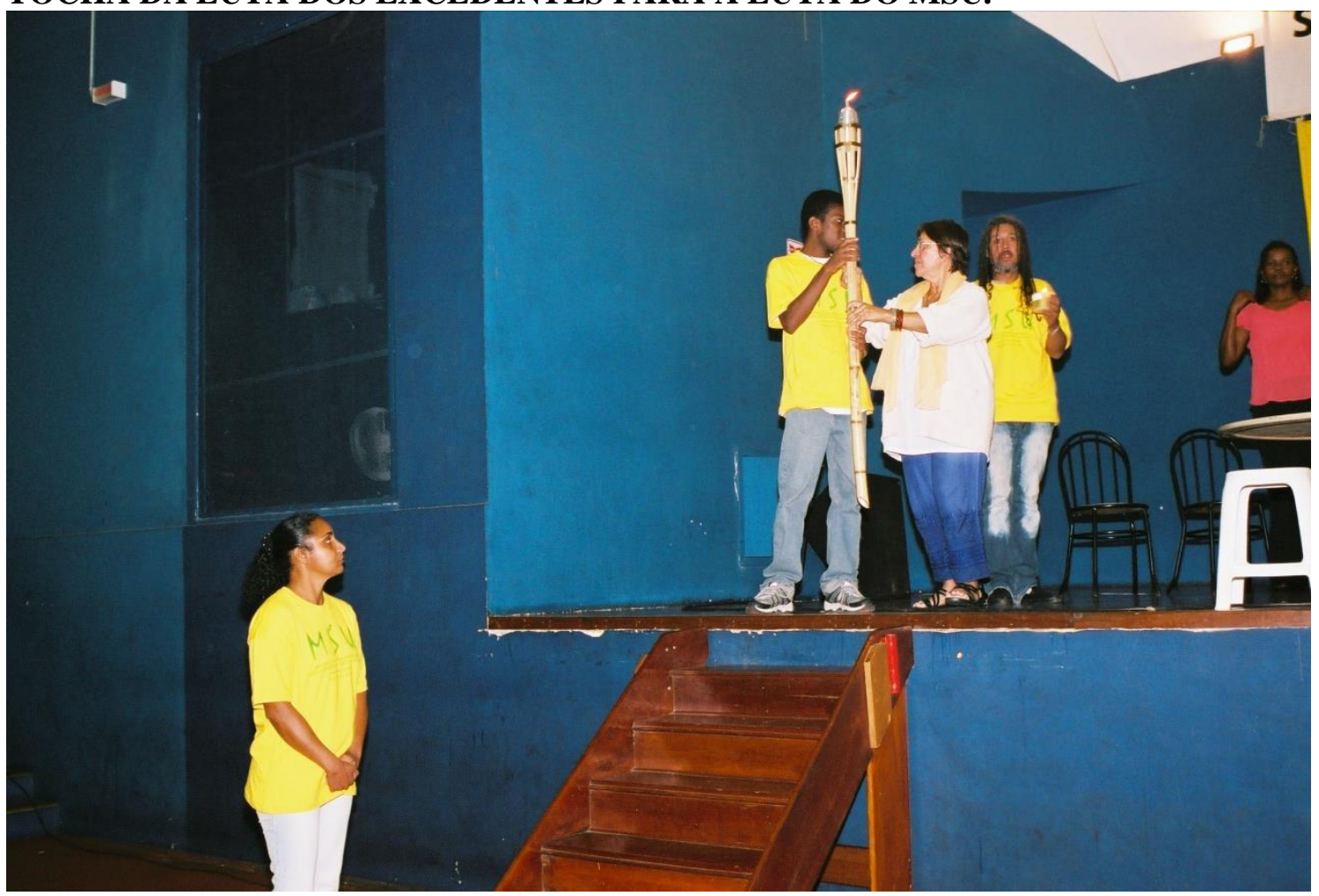

Fonte: Acervo MSU 
FIGURA 32 - ENCONTRO DO MSU EM 2005: CARLÃO ACENDE A TOCHA NAS MÃOS DE DILMA, QUE PARTICIPOU ATIVAMENTE DA LUTA DOS EXCEDENTES NOS ANOS 1960 NO BRASIL.

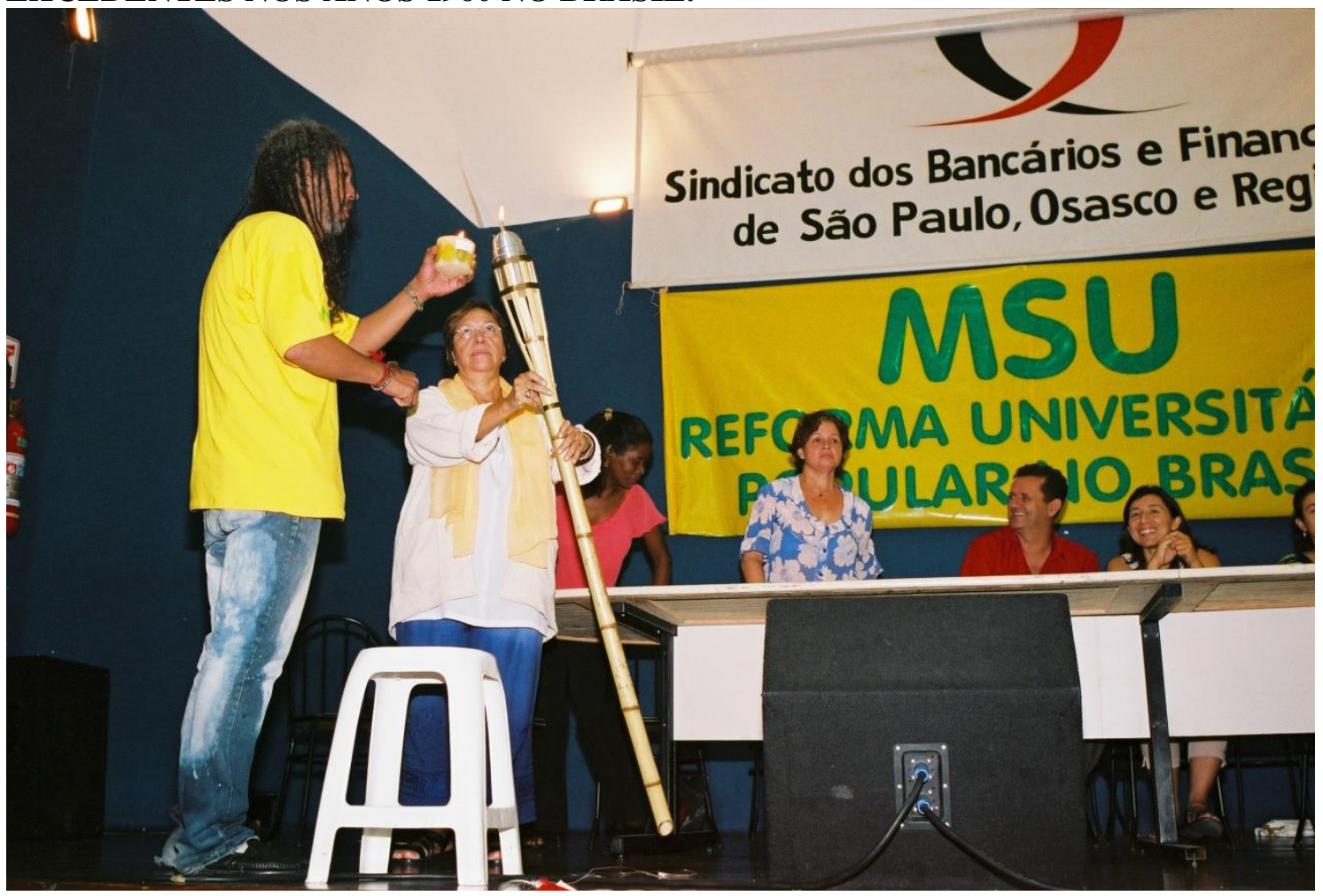

Fonte: Acervo MSU

FIGURA 33 - ENCONTRO DO MSU EM 2005: FLORES E HOMENAGEM.

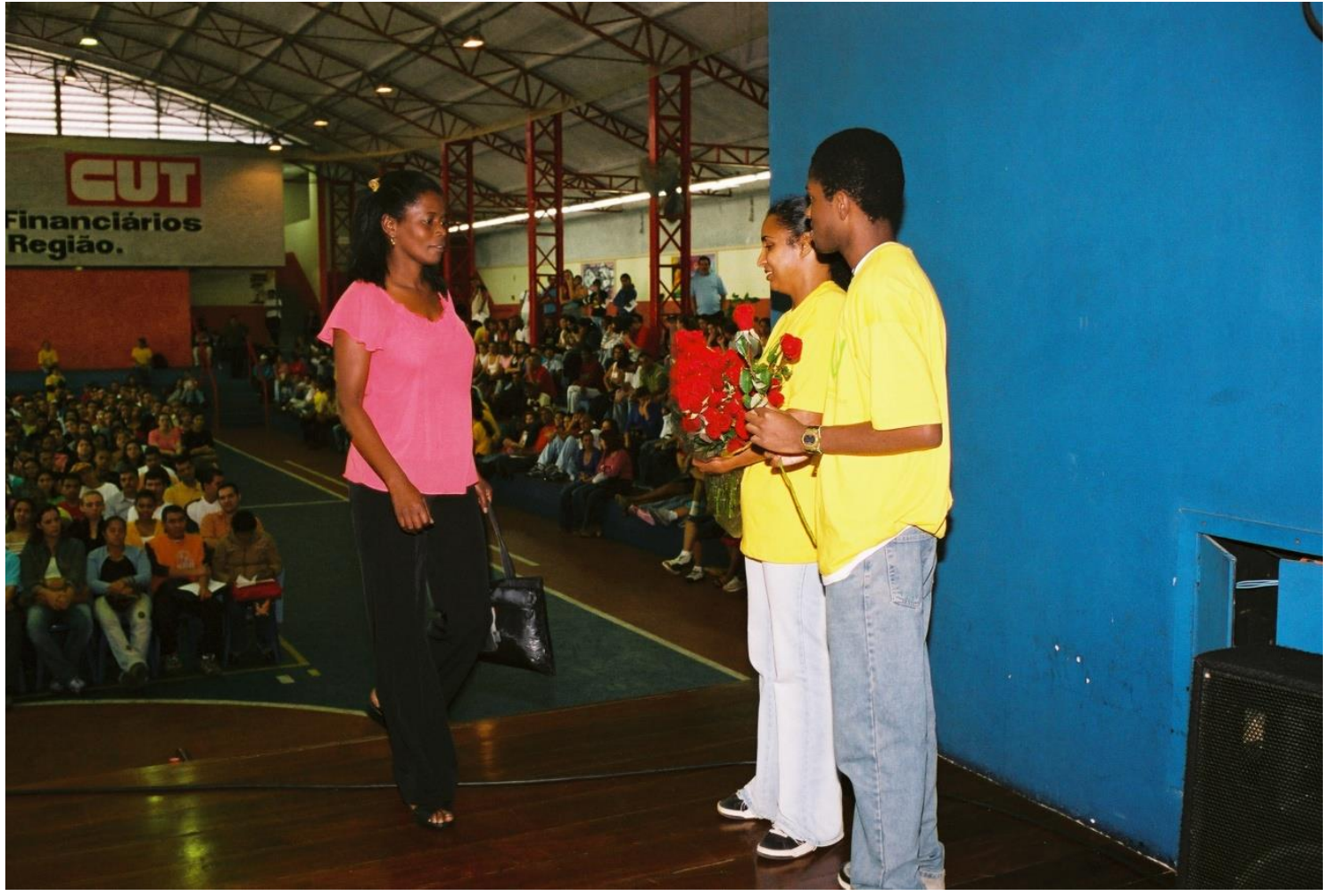

Fonte: Acervo MSU 
FIGURA 34 - NA CRISE POLÍTICA DE 2005 O MSU TOMA POSIÇÃO NA DEFESA DO GOVERNO DE UM SEM UNIVERSIDADE, O PRESIDENTE LULA, COMO NESTE ENCONTRO EM CIDADE TIRADENTES: COMPROMISSO DO PRESIDENTE LULA DE CRIAR A UFABC E ABRIR AS PORTAS DA UNIVERSIDADE PARA O POVO!

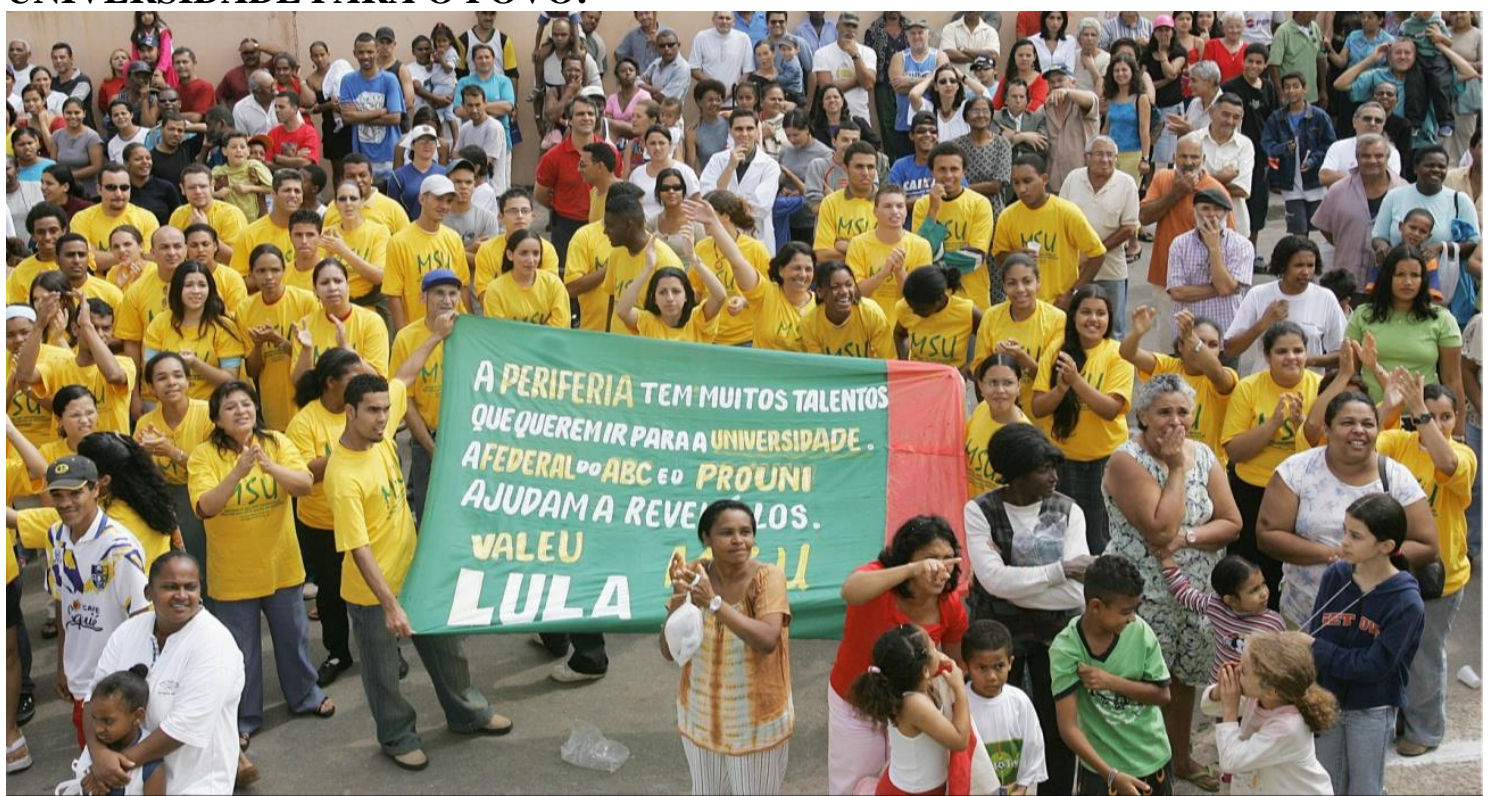

Fonte: Acervo MSU

FIGURA 35 - NO SENADO FEDERAL EM DEZEMBRO DE 2004 COM O SENADOR NEGRO PAUlO PAIM, NA PAUTA A LUTA PELA GARANTIA DA CRIAÇÃO DO SISTEMA NACIONAL DE BOLSAS, O PROUNI, IDEIA QUE BROTA DA LUTA DO MSU NA PERIFERIA DE SÃO PAULO EM 2002.

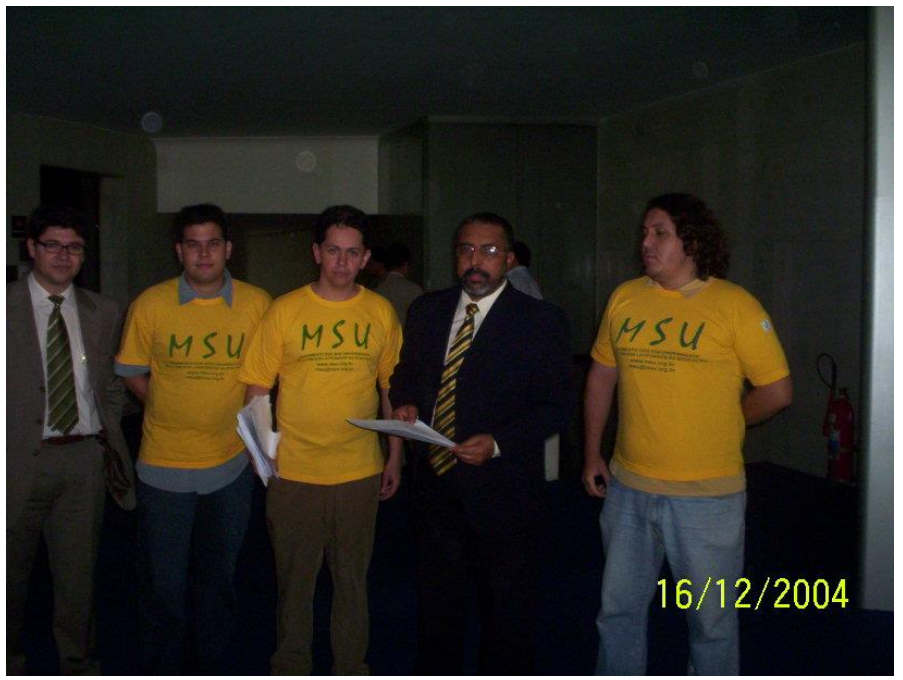

Fonte: Acervo MSU 
FIGURA 36 - MANIFESTAÇÃO CONTRA O RACISMO NA FACULDADE DE DIREITO DA USP E ENTERRO DA INTOLERÂNCIA EM FRENTE À ESTA INSTITUIÇÃO NO ANO DE 2006. EM 2007 O MSU PARTICIPARIA DA OCUPAÇÃO DO LARGO SÃO FRANCISCO EM DEFESA DE COTAS NA USP, QUANDO TOM ZÉ VESTE A CAMISA DO MSU.

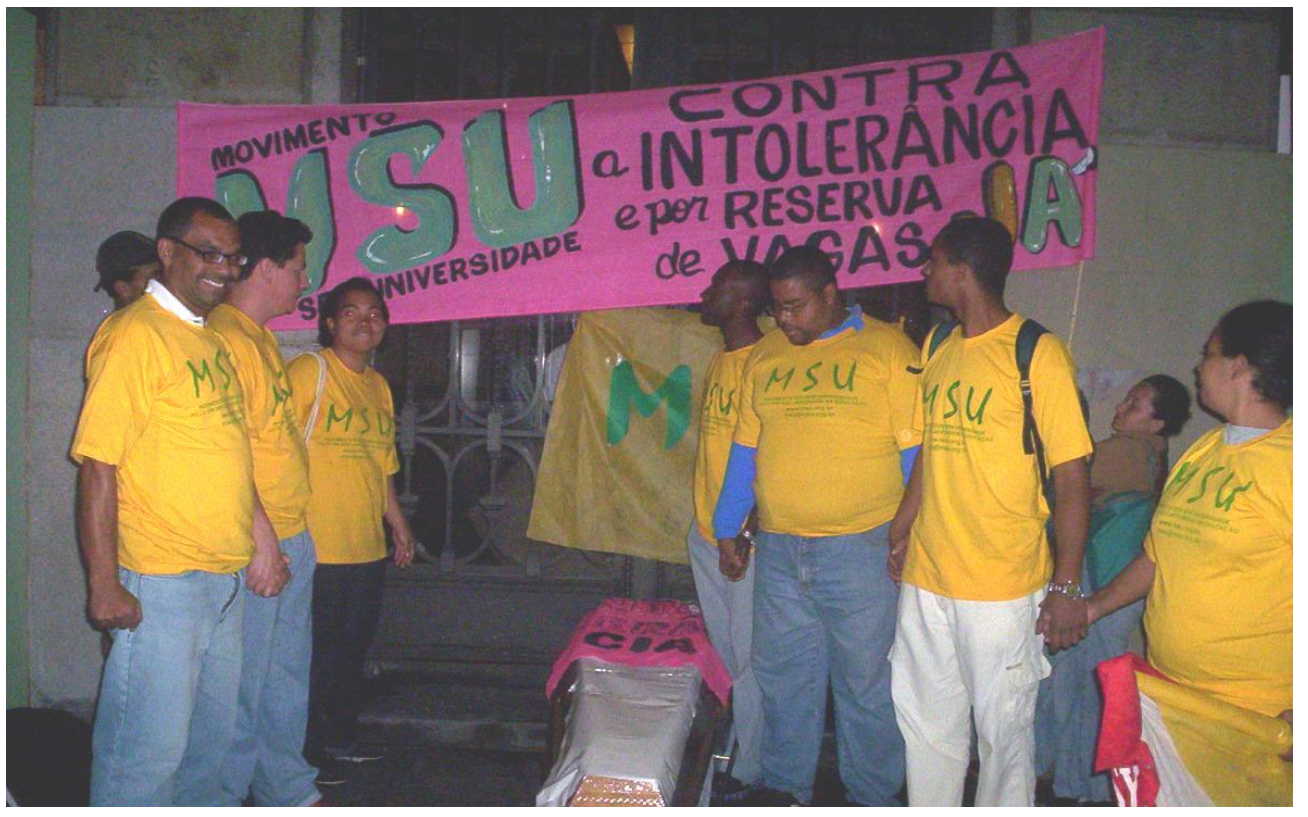

Fonte: Acervo MSU

FIGURA 37 - MANIFESTAÇÃO DO MSU NA CÂMARA DOS DEPUTADOS EM AUDIÊNCIA PÚBLICA EM BRASÍLIA NO PRIMEIRO SEMESTRE DE 2006: DEFESA DA APROVAÇÃO INTEGRAL DO PL 73/99, O PL DE COTAS, COMO APROVADO NA COMISSÃO DE EDUCAÇÃO E DIREITOS HUMANOS EM 2005.

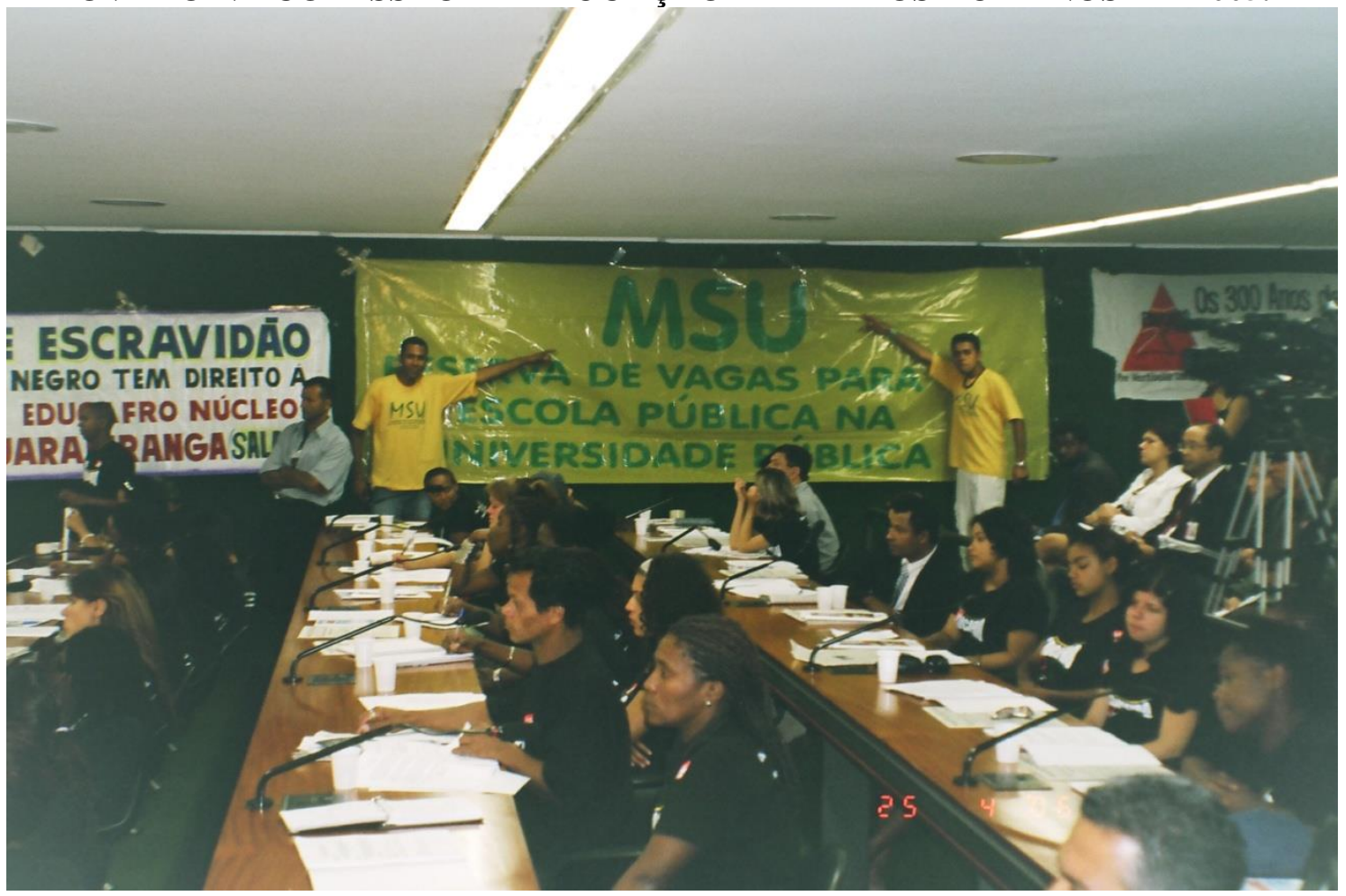

Fonte: Acervo MSU 
FIGURA 38 - SEM UNIVERSIDADE NO CURSINHO POPULAR EM GUAIANASES, PERFERIA DE SÃO PAULO, 2003.

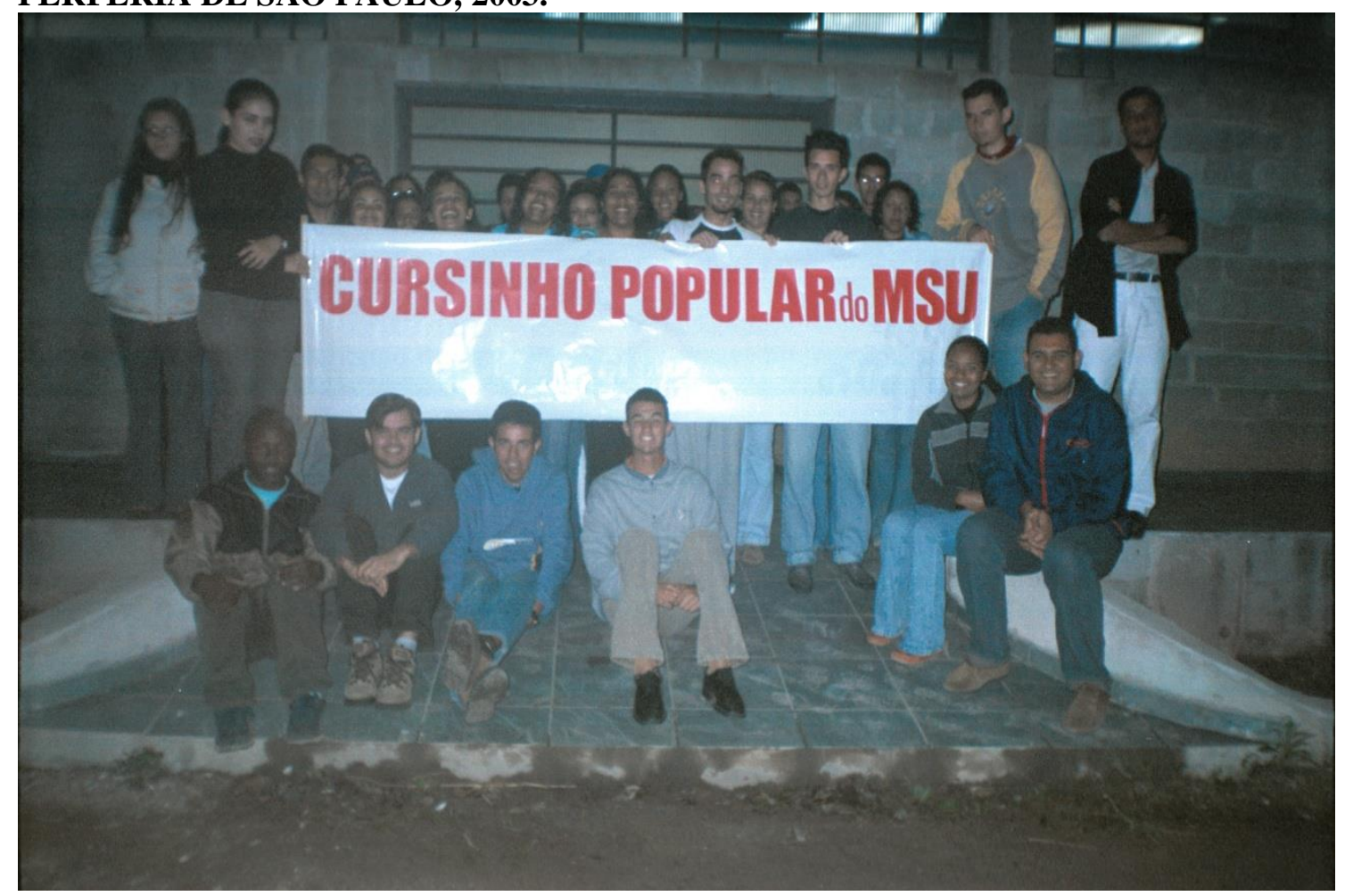

Fonte: Acervo MSU 
FIGURA 39 - MANIFESTAÇÃO NO PORTÃO PRINCIPAL DA USP EM 2003: BANDEIRA DE UMA REFORMA UNIVERSITÁRIA POPULAR APARECE! AS BECAS NA CENA SIMBOLIZAM O DISCURSO DA EXCLUSÃO DA UNIVERSIDADE NO BRASIL

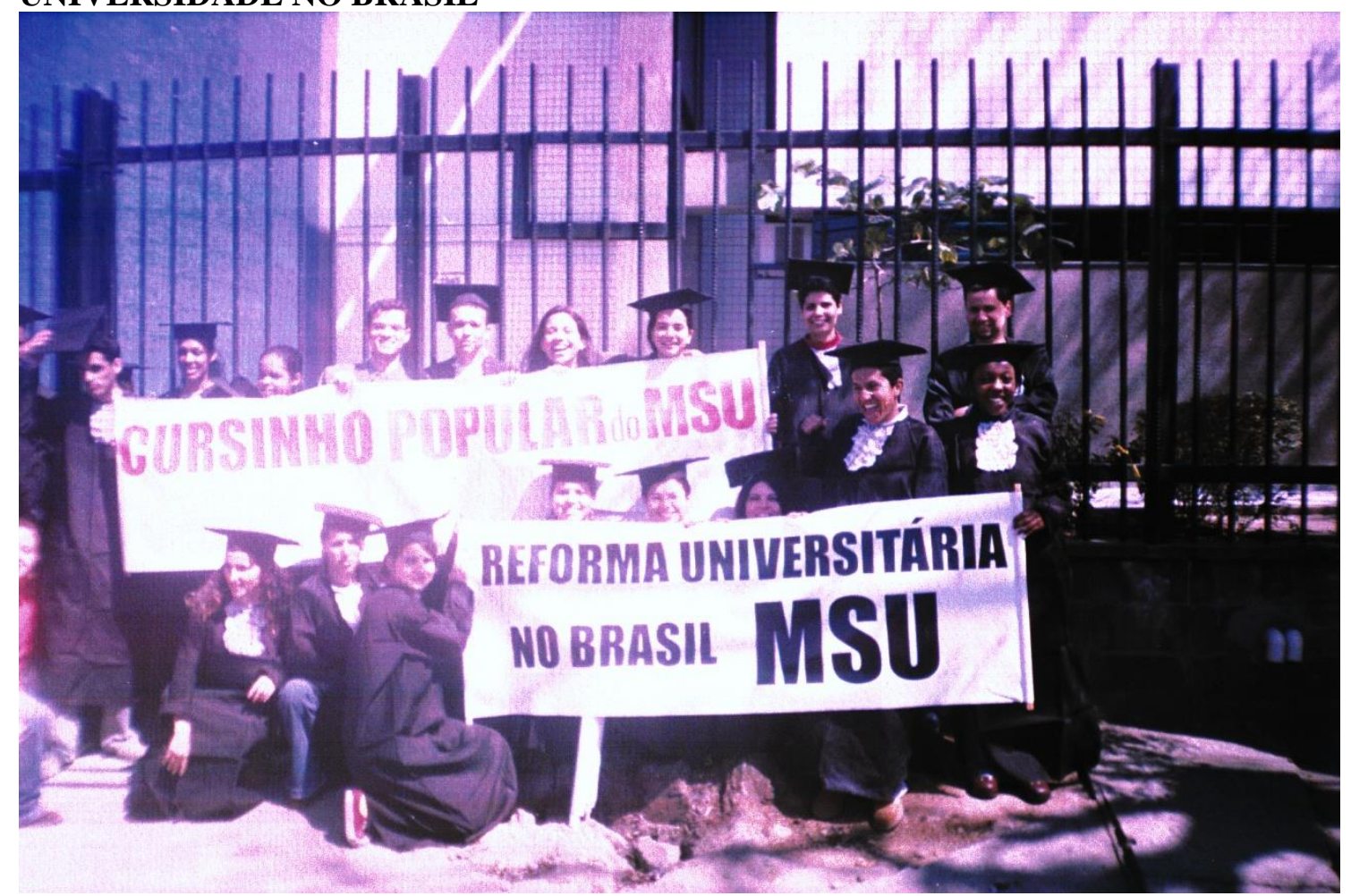

Fonte: Acervo MSU 
FIGURA 40 - RECONHECIMENTO PÚBLICO DA PRESIDÊNCIA DA REPÚBLICA FEDERATIVA DO BRASIL DO PAPEL DO MSU NA CONQUISTA DO PROUNI NO BRASIL: O MSU FALA NA CERIMÔNIA DE LANÇAMENTO DO PROUNI EM 13 DE JANEIRO DE 2005 NO PALÁCIO DO PLANALTO EM BRASÍLIA.

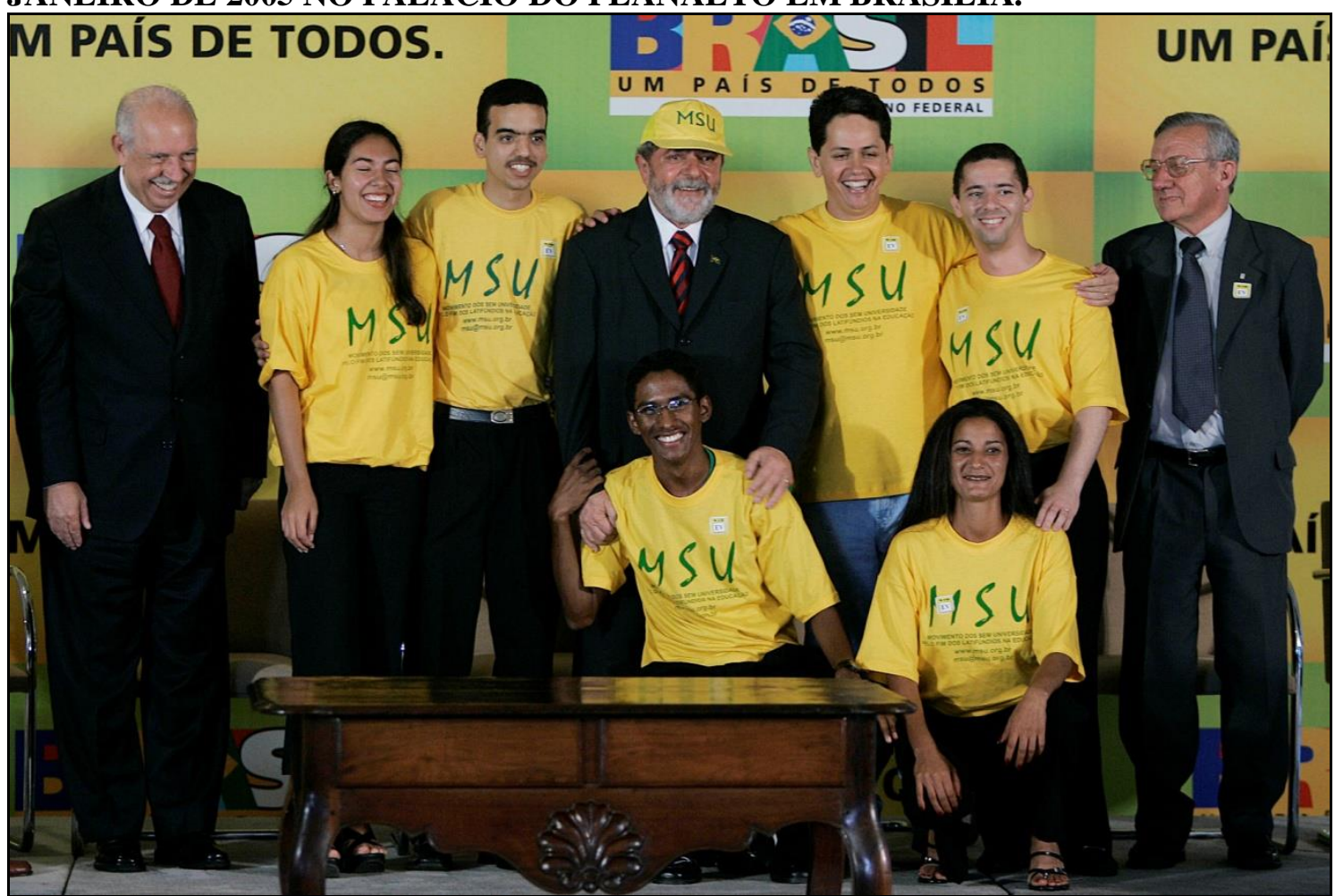

Fonte: FOTO RICARDO STUCKER.

FIGURA 41 - MARCHA DO MSU DA FAVELA AO LADO DA DASLU ATÉ A LOJA DE LUXO: CONTRA A DESIGUALDADE SOCIAL NO BRASIL, 2005.

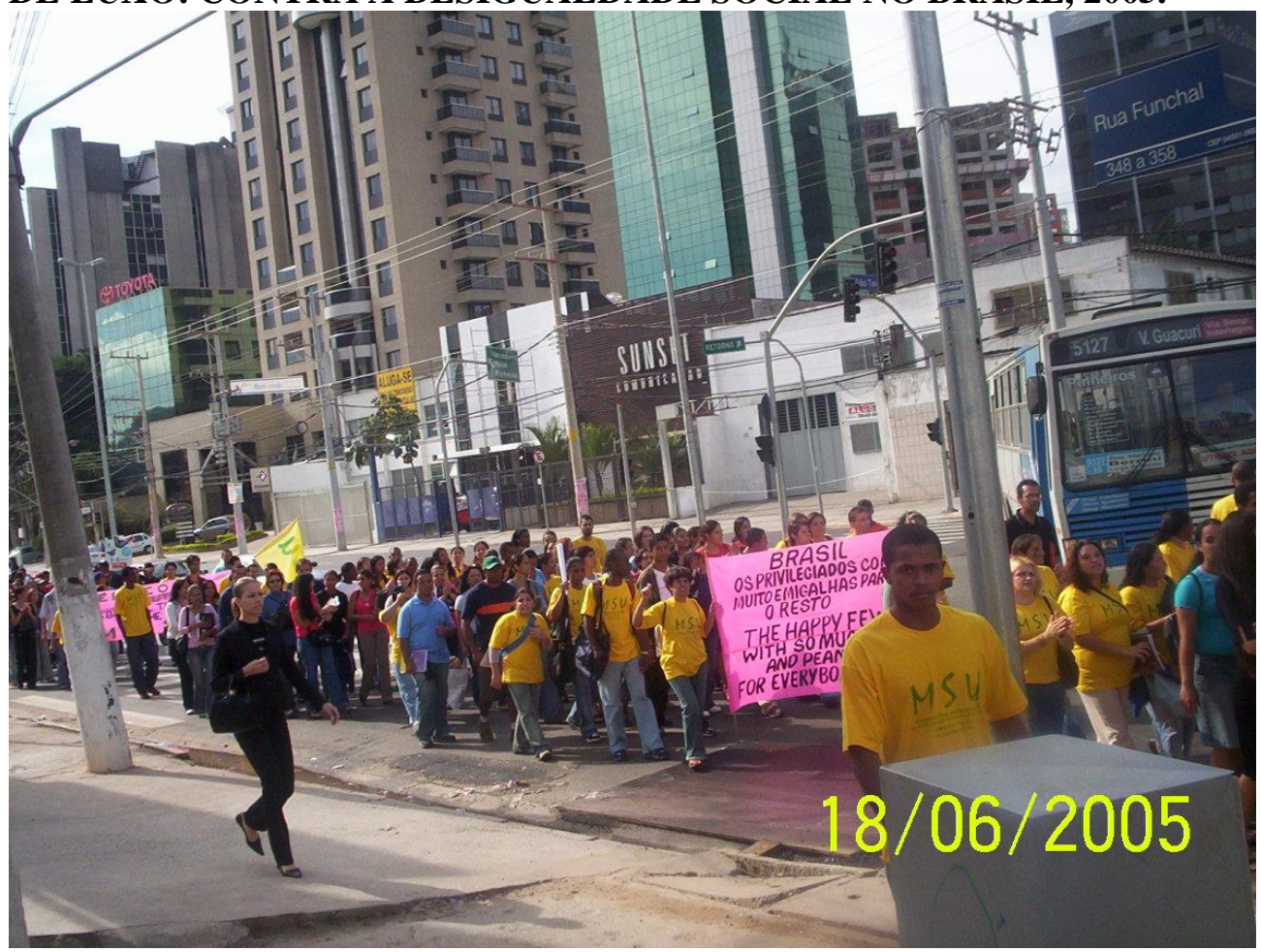

Fonte: Acervo MSU 
FIGURA 42 - MARCHA DO MSU NA DASLU EM 2005.

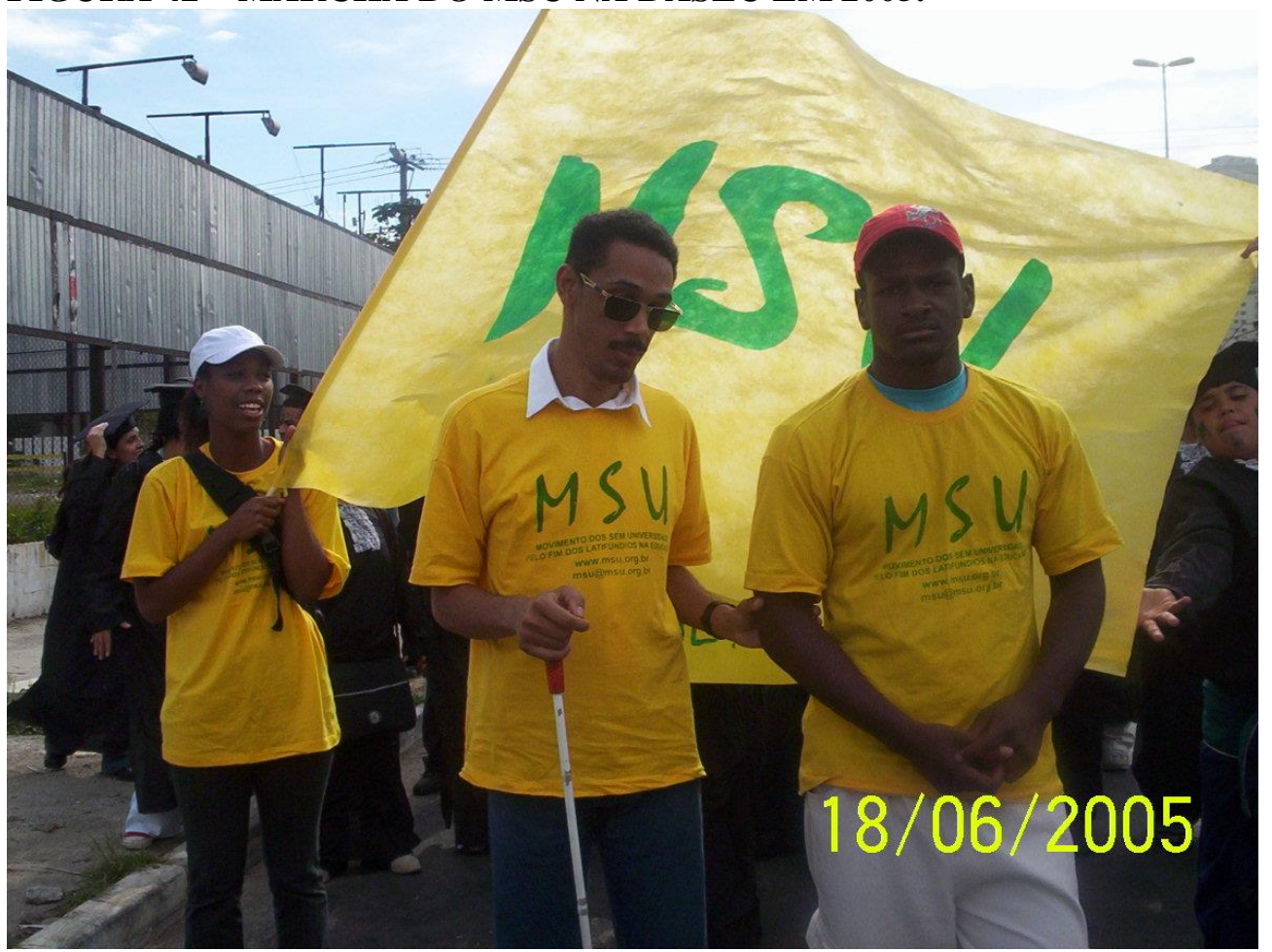

Fonte: Acervo MSU 
FIGURA 43 - EM DUAS PLACAS DE PEDRA, COMO OS DEZ MANDAMENTOS DE MOISÉS, O MSU ENTREGA AO MINISTÉRIO DA EDUCAÇÃO 10 PROPOSTAS PARA UMA REFORMA UNIVERSITÁRIA POPULAR NO BRASIL. O ENEM COMO CRITÉRIO DE ACESSO APARECE COMO PRIMEIRA PROPOSTA INSCRITA NA PEDRA. A JORNALISTA LUCIANA CONSTANTINO, DA SUCURSAL DE BRASÍLIA DO JORNAL FOLHA DE SÃO PAULO, COBRIU REGISTROU ESTE ATO PARA A HISTÓRIA DO BRASIL EM 2005.

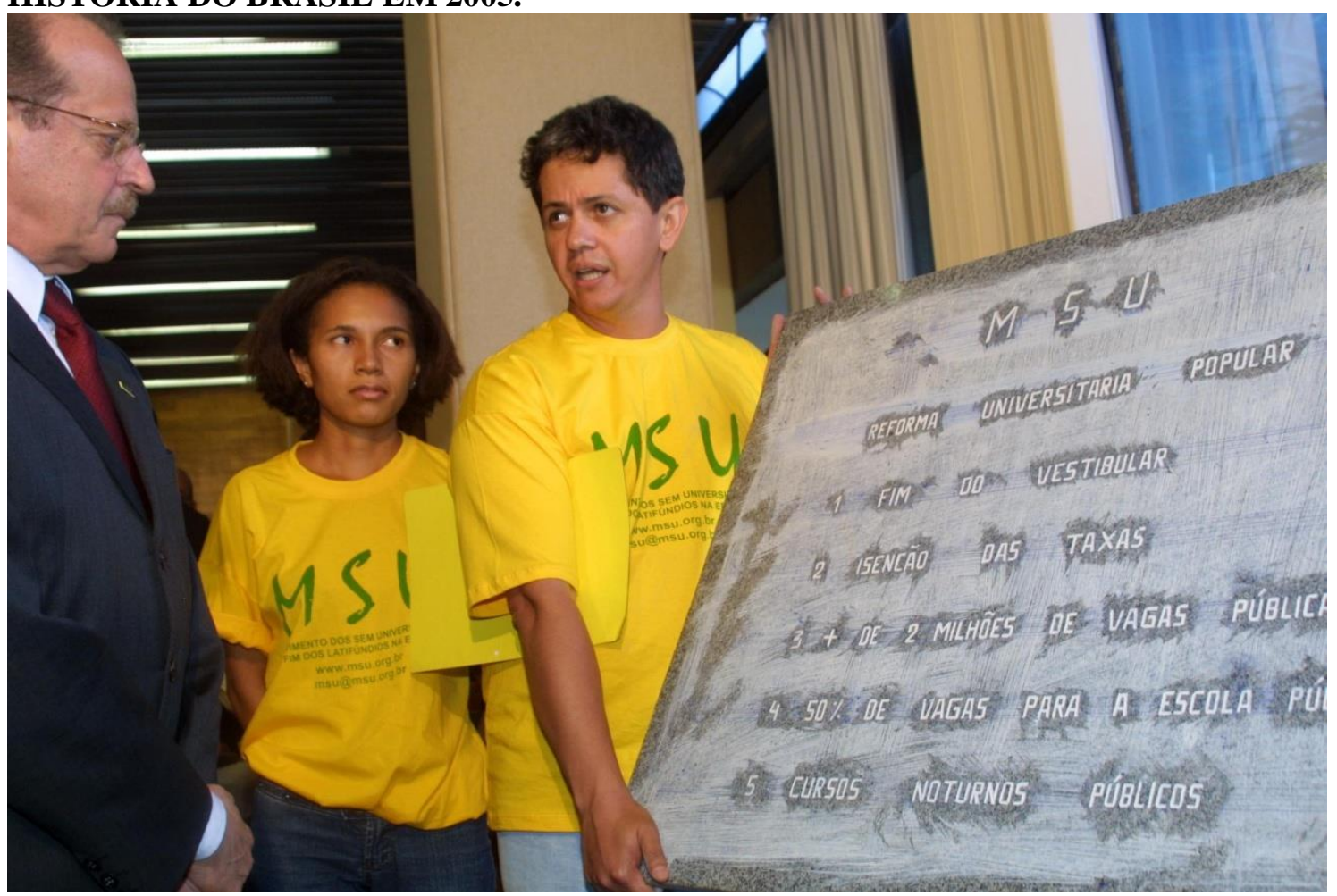

Fonte: Acervo MSU

MSU entrega sugestão à reforma universitária

Segunda-feira, 14 de março de 2005 - 17:20

Estudantes do Movimento dos Sem Universidade (MSU) apresentaram hoje, 14, ao ministro da Educação, Tarso Genro, uma lista com dez sugestões à reforma universitária. Entre outros pedidos, o documento sugere a substituição do vestibular pelo Exame Nacional do Ensino Médio (Enem), a inserção de taxas no processo seletivo das universidades e a criação de dois milhões de vagas nas universidades públicas.

De acordo com o MSU, em muitos casos o que se pede nos processos seletivos das universidades federais é bem distante do que se aprende nas escolas públicas, alimentando uma indústria de cursos preparatórios para o vestibular. Por isso, segundo seus representantes, o Enem deveria ser utilizado como a primeira etapa de acesso às universidades.

Os estudantes pedem também a garantia de 50\% das vagas nas universidades para alunos de escolas públicas, a criação de mais cursos públicos noturnos, a ampliação das políticas afirmativas para negros e índios, a garantia de permanência das classes populares com subsídios como transporte, alimentação, moradia, emprego e livros, a criação de uma tevê universitária aberta e o comprometimento das universidades públicas com projetos de desenvolvimento do país.

O documento com as reivindicações - esculpido em granito, simbolizando os 10 mandamentos bíblicos foi entregue pelos estudantes ao ministro. (Assessoria de Comunicação Social do MEC)

Palavras-chave: mec, notícias, jonalismo, matérias 
FIGURA 44 - NENHUM A MENOS: MANIFESTÇÃO EM FRENTE À USP: 300 KILOS DE BANANAS SÃO ENTREGUES NO PORTÃO DA USP CONTRA O ELITISMO DESSA UNIVERSIDADE E POR SUA DEMOCRATIZAÇÃO SOCIAL E RACIAL.

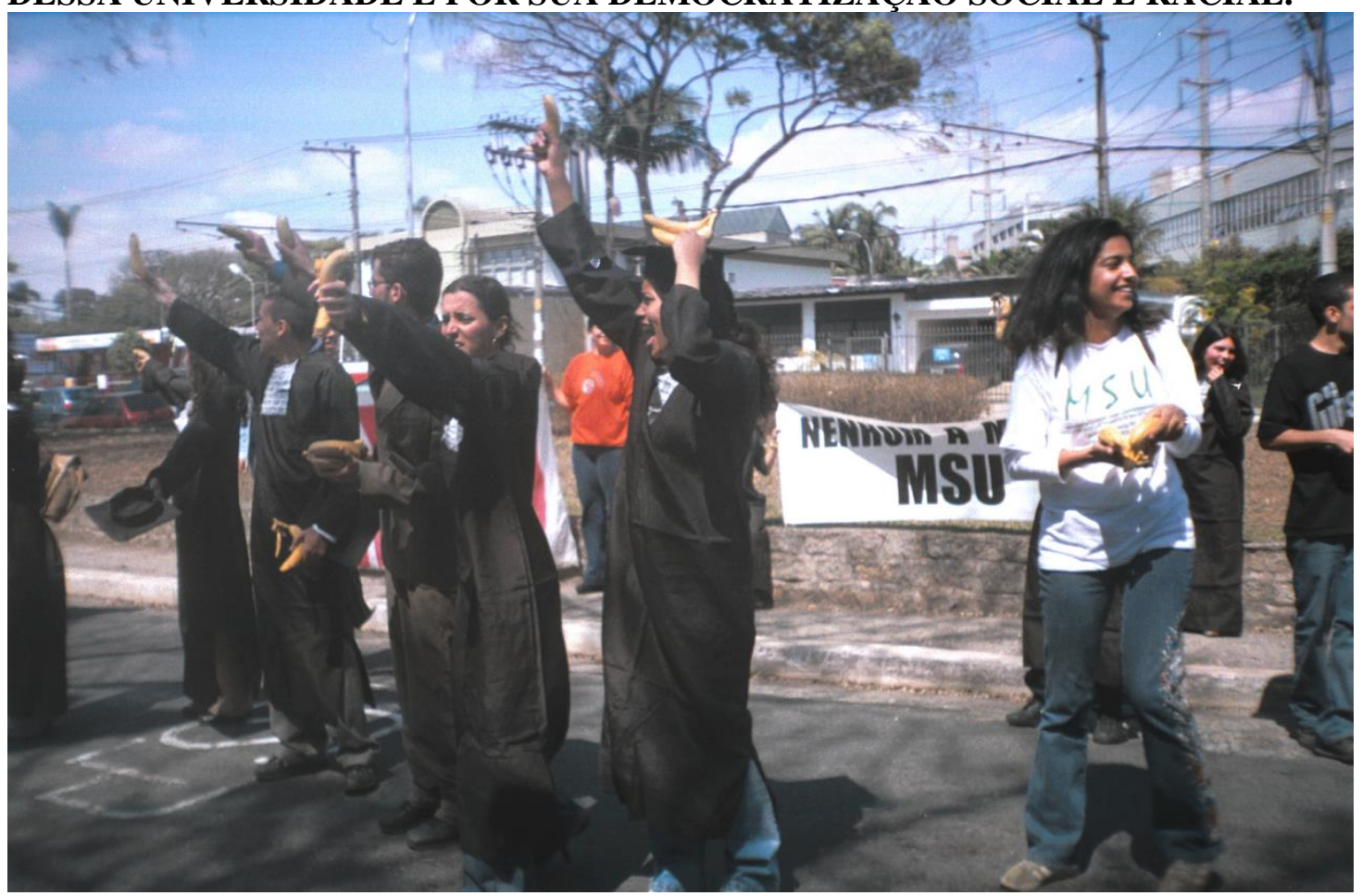

Fonte: Acervo MSU 
FIGURA 36 - FEVEREIRO DE 2006: ALEGRIA PELA APROVAÇÃO DO PL 73/99 NA COMISSÃO DE CONSTITUIÇÃO E JUSTIÇA E CIDADANIA DA CÂMARA DOS DEPUTADOS. QUEBRA-SE O TABU DA IGUALDADE FORMAL NO BRASIL E O DISSCURSO DA DEMOCRACIA RACIAL SOFRE FRAGOROSA DERROTA. O TRABALHO DO MSU NOS CORREDORES DA CÂMARA FOI INTENSO DE DEZEMBRO DE 2005 A FEVEREIRO DE 2006.

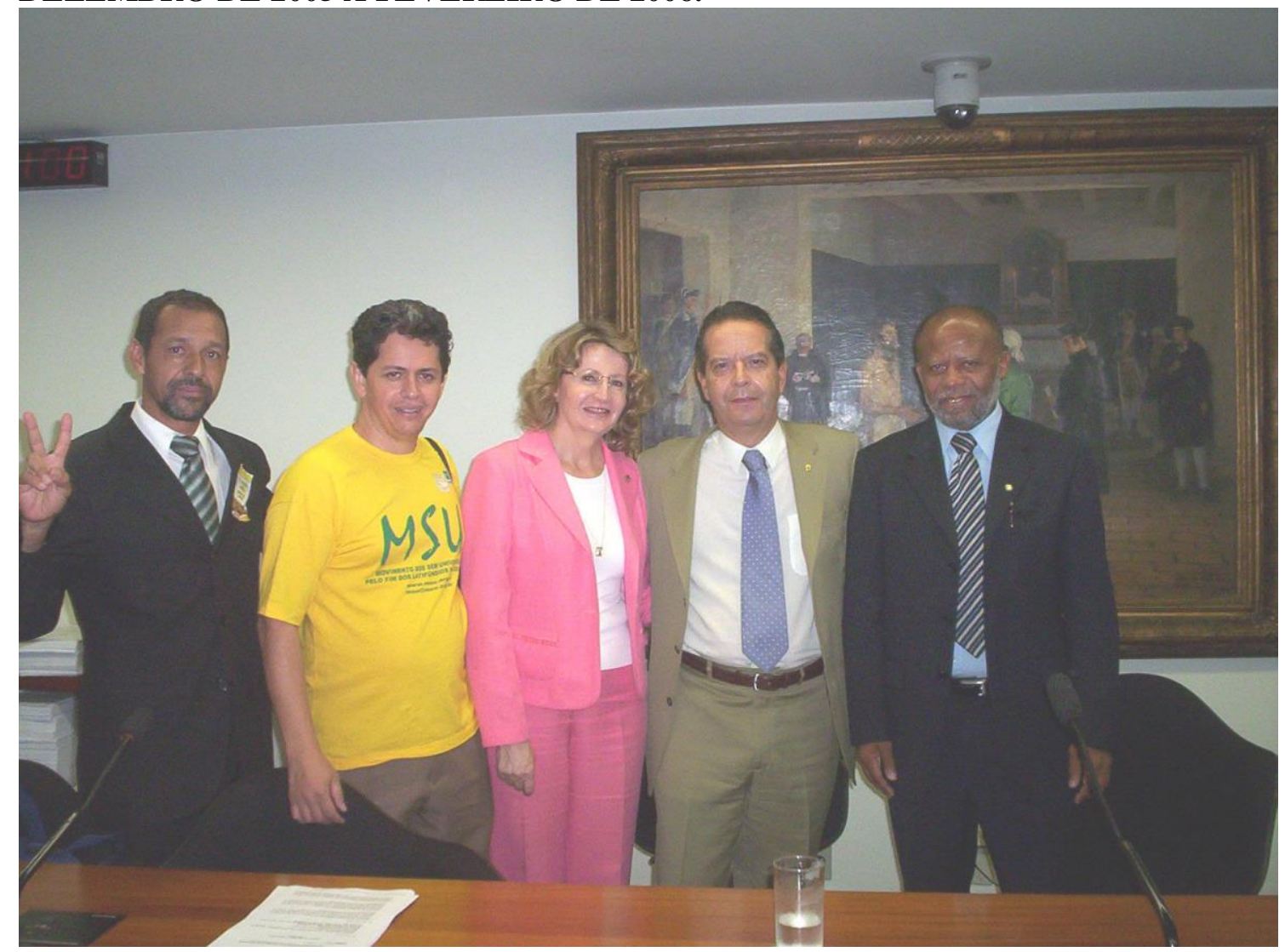

Fonte: Acervo MSU - 08/02/2006 


\section{CONSIDERAÇÕES FINAIS}

A dissertação, ao fim e ao cabo, indica fortes elementos que, de acordo com a metodologia adotada, sustentam a hipótese do surgimento de novíssimos sujeitos sociais na cena pública brasileira, por intermédio da responsabilidade discursiva presente nos discursos vistos.

O estudo indica elementos da presença na história do Brasil do MSU como "educador coletivo", que atualiza experiências de educação popular, como aquelas do Teatro Experimental do Negro (TEN), de Abdias do Nascimento, e dos Círculos Populares de Cultura, de Paulo Freire, que atuavam, dentre outras dimensões, no combate a analfabetização imposta a negros, pobres, indígenas no Brasil. Noutro tempo, a ação de educação popular do MSU centra-se no combate à exclusão do negro, da negra, do indígena, dos pobres, da escola pública do acesso à universidade no Brasil.

Assim, como aquelas referência históricas, o MSU conseguiu levar a dor privada para a cena pública, como o discurso dos Sem Universidade no Brasil.

A responsabilidade discursiva é atestada por um conjunto de registros documentais individuais e por ações na cena pública brasileira.

O confronto interdiscursivo é nítido naqueles ambientes privados mais atinentes à noção de sala de aula da educação popular e seus documentos, bem como noutros espaços discursivos, onde emerge sim uma responsabilidade discursiva coletiva que envolve bastante gente.

Essa responsabilidade discursiva, que é simultaneamente individual e coletiva, texto e prática discursiva, cena discursiva e símbolo discursivo, tem na palavra NÃO um polo nuclear de seu discurso: não contentamento com a situação de exclusão, não comodismo, não alienação, não assujeitamento e luta discursiva por direitos historicamente negados.

A vitória em políticas reais atestam a força discursiva e mobilizadora dos Sem Universidade no Brasil, porque não a própria emergência do discurso dos Sem Universidade, do MSU no solo pátrio.

Com isso, os discursos constituintes do indianismo e do mulatismo, o discurso de Uns, sintetizados no estudo na métrica oportunista do discurso atualizado da 
democracia racial, sofreram derrotas pontuais para os discursos dos povos indígenas, o discurso da negritude - como adotado no estudo, o discurso dos Outros. Dentro dos discursos dos Outros emerge o discurso dos Sem Universidade para o direito de negros, de negras, indígenas, pessoas de baixa renda e oriundos da escola pública à universidade no Brasil.

Mas, como indica um dos documentos textuais, isso não significa o fim da desigualdade racial e social no Brasil, nem que aqueles outros discursos aposentaram suas chuteiras. Pelo contrário, ao dar amplitude a esse debate da emergência do discurso dos Sem Universidade no Brasil, revela-se a sobrevivência no tempo dos discursos estigmadores dos Outros sociais no Brasil, que se traduz na perpetuação de certa visão do status quo e da desigualdade social. Variados casos de racismo e a presença de fascismos na cena pública brasileira em 2013/2014 indicam que os confrontos interdiscursivos entre Uns e Outros, continuam, agora como condição para a defesa da própria democracia brasileira e a superação necessária de seus percalços civis, políticos, sociais e raciais. 


\section{REFERÊNCIAS}

ADAM, Jean-Michel. A linguística textual: introdução à análise textual dos discursos. São Paulo: Cortez Editora, 2011.

ARAÚJO, Valéria et. al.. Povos indígenas e a lei dos "brancos": o direito à diferença. Brasília: UNESCO/MEC, 2006.

AUTHIER-REVUZ, Jacqueline [1982]. Entre a transparência e a opacidade. Revisão técnica da tradução: Leci Borges Barbisan e Valdir do Nascimento Flores. Porto Alegre: EDIPUCRS, pp. 11-80, 2004.

AZEVEDO, Fernando de. A transmissão da cultura. São Paulo: Melhoramentos, 1976 .

BAKHTIN, Mikhail. A cultura popular na idade média e no renascimento: o contexto de François Rabelais. São Paulo-Brasília: Hucitec-Editora da UNB, 2008.

La poétique de Dostoiévski, Seuil, Paris, 1970.

BILDEN, Rudiger. Relações raciais na América Latina com especial referência ao desenvolvimento de uma cultura nativa. Texto apresentado na mesa-redonda sobre as relações latino-americanas no Institute of Public Affairs, University of Virgínia, em 1/7/1931, às 09:30h. Universidade de Virgínia: Albert and Shirley Small Collections Library. Tradução de Sônia Midori. IN PALLARES-BURKE (O sucesso do fracasso), pp. 383-392, 2012.

BOURDIEU, Pierre. A miséria do mundo, Rio de Janeiro: Editora Vozes, 2011.

Esboço de auto-análise. São Paulo: Companhia das Letras, 2005. 
Questões de sociologia. Rio de Janeiro: Marco Zero, 1983.

. Sobre o Estado. São Paulo: Companhia das Letras, 2012.

O poder simbólico. Rio de Janeiro: Bertrand Brasil, 1998.

BOSI, Alfredo. Essencial Padre Antônio Vieira. São Paulo: Penguim Classics Companhia das Letras, 2011.

CÂMARA dos Deputados. Constituição 20 anos: Estado, democracia e participação popular. Brasília: Comissão de Legislação Participativa, Edições Câmara, 2009.

CANDIDO, Antonio. O discurso e a cidade. São Paulo: Livraria Duas Cidades, 1993.

CANETTI, Elias. Massa e Poder. Tradução de Sérgio Tellaroli. São Paulo: Companhia das Letras, 1995.

CHAUÍ, Marilena. Brasil: mito fundador e sociedade autoritária. São Paulo: Editora Fundação Perseu Abramo, 2000.

CUNHA, Euclides da. [1902]. Os Sertões. Edição de Leopoldo M. Bernucci. Cotia: Ateliê Editorial, 2002.

CUNHA, Manuela Carneiro da. Negros, estrangeiros. São Paulo: Companhia das Letras, Segunda edição revista e ampliada, 2012.

Índios no Brasil: história, direitos e cidadania. São Paulo: Claro Enigma, 2012.

CASTRO, Cloves Alexandre de. Cursinhos alternativos e populares: movimentos territoriais de luta pelo acesso ao ensino público superior no Brasil. UNESP: dissertação de mestrado, departamento de geografia, Presidente Prudente, 2005.

CERTEAU, Michel de. A invenção do cotidiano. Rio de Janeiro: Editora Vozes, 2 Volumes, 2011.

CHALHOUB, Sidney. A força da escravidão - ilegalidade e costume no Brasil oitocentista. Companhia das Letras, São Paulo, 2012. 
CHAMPAGNE, Patrick. Pierre Bordieu, Editions Milan: Toulose, 2008.

COSTA, Emília Viotti da. Da Monarquia à República. São Paulo: Editora Unesp, 2010.

CUSTÓDIO, Sérgio José. Cursinhos populares: democratização do acesso à universidade e inclusão social. Instituto de Economia Unicamp, 1999.

A emergência do neobranqueamento no Senado Federal. Congresso em Foco (www.congressoemfoco,com.br), Brasília, 2009.

DÁVILA, Jerry. Diploma de Brancura: política social e racial no Brasil - 19171945. São Paulo: Editora da Unesp, 2005.

DUARTE, Eduardo de Assis. Machado de Assis afrodescendente. Editora Pallas e Editora Crisálida. Belo Horizonte/Rio de Janeiro, 2007.

DUFOUR, Danny-Robert. (2003). A arte de reduzir as cabeças: sobre a nova servidão na sociedade ultraliberal. Tradução de Sandra Regina Filgueiras. São Paulo: Companhia de Freud, 2005.

FACEIRA, Lobélia da Silva. O prouni como política pública em suas instâncias macro-estruturais, meso-institucionais e microssociais: pesquisa sobre sua implementação pelo MEC e por duas universidades na região metropolitana do Rio de Janeiro. Rio de Janeiro: PUC-RIO, Tese de doutorado, departamento de Educação, 2009.

FELTRAN, Gabriel. Fronteiras de tensão: política e violência nas periferias de São Paulo. São Paulo, Editora Unesp, 2011.

FERNANDES, Florestan; BASTIDE, Roger. Brancos e negros em São Paulo. São Paulo: Companhia Editora Nacional, 1959.

O negro no mundo dos brancos. São Paulo: Global Editora, [1969] 2007.

. Significado do protesto negro. São Paulo: Cortez Editora, 1989. 
Relações de raça no Brasil: realidade e mito. In Brasil: Tempos Modernos. Coletânea de ensaios coordenada por Celso Furtado. Rio de Janeiro: Editora Paz e Terra Ltda, 1968.

FILHO, Geraldo Sabino Ricardo. A boa escola no discurso da mídia: um exame das representações sobre educação na revista Veja (1995-2001).

FOUCAULT, Michel. A arqueologia do saber. Rio de Janeiro: Forense Universitária, 1986.

FREIRE, Ana Maria Araújo. Paulo Freire: uma história de vida. São Paulo: VILLA DAS LETRAS, 2006.

FREIRE, Paulo. Educação e atualidade brasileira. São Paulo: Editora Cortez, 2001 [1959].

FREYRE, Gilberto. (1933). Casa-Grande \& Senzala. Rio de Janeiro: José Olympio Editora, 25 edição, 1987.

FURTADO, Celso. Formação econômica do Brasil. São Paulo: Companhia das Letras, 1959.

GARCIA, Antonia dos Santos. Desigualdades raciais e segregação urbana em antigas capitais. Rio de Janeiro: Garamound Universitária e FAPERJ, 2009.

GERALDI, João Wanderley. Portos de passagem. São Paulo: Editora Martins Fontes, 2013.

GINZBURG, Carlo [1976]. O queijo e os vermes: o cotidiano e as ideias de um moleiro perseguido pela inquisição. São Paulo: Companhia das Letras, 1987.

Sinais: raízes de um paradigma indiciário. In Mitos, emblemas, sinais. São Paulo: Companhia das Letras, 1986, pp. 143-179.

GOMES, Flávio dos Santos. A hidra e os pântanos: mocambos, quilombos e comunidades de fugitivos no Brasil (séculos XVII-XIX). 
GUIMARÃES, Antonio Sérgio Alfredo. Cidadania e retóricas negras de inclusão social. São Paulo: Revista Lua Nova, n. 85, pp. 13-40, 2012.

HASENBALG, Carlos. O contexto das desigualdades raciais. In SOUZA, Jessé (Org.). Brasília: Paralelo 15 editores e Secretaria dos Direitos da Cidadania do Ministério da Justiça, p. 63-68, 1997.

HANKS, W. F. Língua como prática social. São Paulo: Cortez Editora, 2008.

HENRIQUES, Ricardo. Desigualdade racial no Brasil: evolução das condições de vida na década de 90. Texto para Discussão número 807. Rio de Janeiro: IPEA, 2001.

HOFBAUER, Andreas. Uma história de branqueamento ou o negro em questão. São Paulo: Editora Unesp, 2006.

JUNIOR, Caio Prado. Formação do Brasil Contemporâneo. São Paulo: Brasiliense, 1936.

LUSTOSA, Isabel. Insultos impressos. São Paulo: Companhia das Letras, 2000.

MAINGUENEAU, Dominique. Doze conceitos em análise do discurso. Organização de Sírio Possenti e Maria Cecília P. Souza-e-Silva. In Polifonia, provérbio e desvio. Tradução de Maria Cecília P. Souza-e-Silva. São Paulo: Editora Parábola, 2010.

Gênese dos discursos. Tradução de Sírio Possenti. São Paulo: Editora Parábola, [1995] 2008.

. Discurso literário. São Paulo: Editora Contexto, 2012.

. Cenas da enunciação. In: POSSENTI, Sírio; SOUZA-E-SILVA, Marica Cecília Pérez de. Cenas de Enunciação. São Paulo: Editora Parábola, [2006] 2012.

MARCÍLIO, Maria Luiza. História da escola em São Paulo e no Brasil. São Paulo: Instituto Braudel/Imprensa Oficial, 2005.

MOEHLECKE, Sabrina. Propostas de ações afirmativas no Brasil: o acesso da população negra ao ensino superior. São Paulo: USP, dissertação de mestrado, Faculdade de Educação, 2000. 
Fronteiras de igualdade racial no ensino superior: excelência \& justiça racial. São Paulo: USP, tese de doutorado, Faculdade de Educação, 2004.

MOTTA, Ana Raquel. Racionais MCs: uma enunciação aforizante. In MOTTA, ANA RAQUEL; SALGADO, LUCIANA et all. Fórmulas Discursivas. São Paulo: Editora Contexto, p. 163-173, 2011.

NASCIMENTO, Abdias do. O negro revoltado. Rio de Janeiro: Edições GRD, 1968.

Teatro Experimental do Negro: trajetórias e reflexões. São Paulo: Estudos Avançados, volume 18, n. 50, p. 209-224, 2004.

O quilombismo: documentos de uma militância pan-africana. Petrópolis: Vozes, 1980.

NIETZSCHE, Friedrich. (1882). A gaia ciência. São Paulo: Abril Cultural, Os pensadores, 1995.

PANOFSKY, Erwin. Arquitetura gótica e escolástica. São Paulo: Martins Fontes, 1991.

PAIXÃO, Marcelo; ROSSETO, Irene; MONTOVONALE, Fabiana; CARVANO, Luiz M. (Orgs.). Relatório Anual das Desigualdades Raciais no Brasil; 2009-2010. Rio de Janeiro: Editora Garamond Ltda, 2010.

PÊCHEUX, Michel. O Discurso. (1982). Tradução de Eni Puccinelli Orlandi. Campinas: Pontes, segunda edição, 1997.

. Por uma análise automática do discurso: uma introdução à obra de Michel Pêcheux. Campinas: Editora da Unicamp, 1993.

POSSENTI, Sírio. Questões para analistas de discurso. São Paulo: Parábola Editorial, 2011.

RABELAIS, François. (1552). O terceiro livro dos fatos e ditos heroicos do Bom Pantagruel. Tradução de Élide Valarini Oliver. Ateliê Editorial e Editora da Unicamp: Campinas, 2006. 
RAMOS, Graciliano. (1945). Infância. Rio de Janeiro: Editora Record/Atalaya, 1995.

REVISTA de História da Biblioteca Nacional. Índios. Rio de janeiro: ano 8, número 91, abril de 2013

SADER, Eder. Quando novos personagens entraram em cena. São Paulo: Paz e Terra, 1988.

SANTANA, Marilene. Os modos de didatização em manuais de língua portuguesa para o ensino fundamental no período de 1976 a 1996. São Paulo: USP, tese de doutorado, Faculdade de Educação, 2012.

SEMOG, Éle. Abdias Nascimento o Griot e as muralhas. Rio de Janeiro: Pallas, 2006.

SLENES, Robert. IN GOMES, Flávio dos Santos. IN A hidra e os pântanos: mocambos, quilombos e comunidades de fugitivos no Brasil (séculos XVII-XIX). São Paulo: Editora Unesp, 2005.

SOUZA, Jesse. A construção social da subcidadania - para uma sociologia política da modernidade periférica. Belo Horizonte: Editora da UFMG/IUPERJ, 2006.

2006.

A invisibilidade da desigualdade brasileira. Belo Horizonte: Editora UFMG,

SOUZA E SILVA, Jailton de; BARBOSA, Jorge Luiz. "Por que uns e não outros?": caminhada de jovens pobres para a universidade. Rio de Janeiro: Editora 7 Letras, 2003.

Favela: alegria e dor na cidade. Rio de Janeiro: Senac Rio, 2005.

TEZZA, Cristóvão. Entre a prosa e a poesia: Bakhtin e o formalismo russo. São Paulo: USP, tese de doutorado, 2002.

THEODORO, Mário. (Org.). As políticas públicas e a desigualdade racial no Brasil 120 anos após a abolição. Brasília, IPEA, 2008. 
TOBNER, Odile. Du racisme français: quatre siècles de négrophobie (In Le Sud releve la Tetê, 197-227). Paris: Éditions des Arènes, 2007.

TODOROV, Theodor. Mikhail Bakhtin; Le príncipe dia logique: suei d'Escritas do cerce de Bakhtine. Paris: Seuil, 1981.

TORRES, Demóstenes. Audiência Pública, 2010. Disponível em: $<$ http://www.stf.jus.br/arquivo/cms/processoAudienciaPublicaAcaoAfirmativa/anexo/N otas_Taquigraficas_Audiencia_Publica.pdf > . Acesso em 02/07/2014.

\section{ANEXOS}

\section{D212}

R: "Não sou a favor de cotas na universidades, acho que com um ensino melhor, mais dinâmico a gente cortaria o mal pela raiz. Mas também não discordo é uma maneira deles estarem lutando pelos seus direitos porque do jeito que está não dá pra ficar, só rico fazendo universidade e mandando no nosso país.

As cotas para mim cria um certo racismo não só para com os negros mas também para com os indígenas os nordestinos porque não é só negro que é pobre e estuda em escola pública. Sendo assim as cotas nas universidades deveria ser para quem ganha um salário ou nenhum, deveria ser avaliado a sua vida sócio-econômica. E só entrar em faculdade pública gente pobre com o poder aquisitivo menor".

Q1: "Desempregado, sem moradia e analfabeto".

Q5: "Na periferia as nossas crianças dão valor a quem tem carro, roupas de grife e é repeitado como os traficantes e se espelham neles. Porque seus pais que trabalham mal conseguem dar les o que comer"

D202 
R: "Na USP por exemplo que deveria ser pra pessoas pobres tem muitos ricos. Mas é claro que essas pessoas entram na faculdade pública porque também tem uma boa noção estudam em colégios caros. Mas não é nada justo.[...]

A cota para negros já é uma discriminação isso é racismo, o branco tentando dizer que não é racista criou a cota, todos devem ser iguais.

Para que se entre na universidade, todos (brancos e negros) tem que ter a obrigação de serem educados igualmente, ninguém é melhor que ninguém, direitos iguais.”(1 21 a $28 ; 144$ a 54).

Q1: “A miséria, tem muitas pessoas sem ter o que comer, então como muitos tem família para sustentar acabam praticando furtos, fazem isso porque não tem emprego, não tem estudo, então não pode se obter um bom emprego, moradia então é que fica complicado não é só o negro que sofre, brancos sofrem o mesmo, tem isso de racismo já foi bem pior agora tem tanta gente rica e famosa negras".

Q5: “As pessoas andam tão violentas, tem o medo de sair vivo e não mais voltar, com medo de tudo, uma bala perdida por exemplo. Esses fatos só acontecem porque não se tem educação, se tivesse ninguém precisava de violência para obter mais coisas".

D201

R: "Em relação as cotas para os negros ingressarem na universidade eu acho que não está resolvendo em nada a desigualdade social no país porque cada vez as pessoas ainda discriminam o negro acham que ele não tem condições e capacidade para estar cursando uma universidade além de ser discriminado pela sua cor, porém se algumas universidades não tivessem essas cotas para o negro ingressar na universidade eu acho que sempre eles ficariam sem ter uma chance para melhorar e aprender o estudo do ensino superior para poder concorrer com os outros na vida profissional".

Q1: "Preconceito racial e discriminação racial."

Q5: "O aspecto relacionado é em relação ao desemprego porque o homem sem trabalhar costuma ficar na porta do bar na periferia falando da falta de dinheiro, dos sonhos que falta realizar, dos desejos em ter coisas da moda, da vida pacata no bairro e que devido a situação atual do brasileiro o que você pode comprar é só o necessário para sustentar a família. E sempre você coloca alguém melhor como você para ser sua referência de ser alguém na vida."

D200

R: "Assim um aluno que estuda a maior parte em escolas particulares, quando termina o ensino médio, vão estudar em universidades públicas. E o aluno que estudou, 
em escolas públicas na maioria das vezes trabalham e pagam uma universidade particular. Na realidade ambos se invertem, e o mais preparado, toma o lugar do menos preparado nas universidades. [...]

O fato é pode mais quem tem mais capital, quem não tem se contenta com o que, sobra e quando sobra essa é a nossa Realidade.”(1 14 a 23; 137 a 40).

Q1: “conta a idade, conta o que restou' na realidade o tempo da escravidão ja passou mas a sociedade ainda discrimina o negro. E parece que pode passar o tempo que Passar, algumas pessoas ainda será rascista com o negro.”

Q5: "Infelizmente o nosso cotidiano e basicamente igual a letra da musica, um deles é a falta de emprego. Pois sem o emprego a pessoa não tem como se manter e suprir suas necessidades. E muitas vezes leva um cidadão a cometer varias besteiras como /roubar e matar gerando violência."

D199

R: "Para o meu ponto de vista as universidades particulares e públicas cada vez mais não são para nós da classe média baixa.

Pois uma pessoa que está desempregado não pode pagar uma faculdade nem quem tem emprego não consegue pagar também.

As faculdades públicas só quem estudam nelas são os filhinhos de papais.

Então acho que todos nós que sonhamos em fazer uma faculdade deveríamos lutar para conseguir com que as faculdades públicas desces mais chances para as pessoas que querem ser alguém na vida."

Q1: “Sem diamante, escravidão

Nem pergunto pelos filhos

Ligo o rádio, durmo no colchão"

Q5: "Ultimamente andei ouvindo reclamar

Que a sua falta de dinheiro era problema.

Que a sua vida pacata já não vale a pena.”

D194

R: "O curso superior hoje é de grande importância para se ter um emprego.

Mas o governo não colabora com os menos privilegiados.

Alunos de colégios públicos não tem como competir com estudantes de colégios privados, a concorrência chega a ser desleal. [...]

E as universidades privadas, todos nós sabemos que elas tem uma percentagem de bolsas para oferecer, mas a realidade é outra. 
Elas só pensam em faturar, fatura e faturar.

Acho que o governo deve criar meios de levar menos favorecidos ao curso superior, investindo nos estudos de pessoas carentes como eu." (1 1 a 7;1 15 a 24).

Q1: "Vida presa no quintal"

Q5: "Que a falta de dinheiro era problema.

Se todos tivessem oportunidade de trabalhar e ganhar o suficiente para manter sua família, viveríamos melhor."

D 193

R: "Acho, que deve sim ter um processo seletivo para ingresso a uma universidade, mas teria que ter um sistema de cotas para alunos que estudaram em escolas públicas e que tem baixa renda familiar.

As pessoas de classe social inferior não tiveram a mesma oportunidade do que os de classe superior tiveram.

Um exemplo disso é a cultura, as pessoas que tem mais condições tem acesso a assinatura de jornais e revistas, compra de livros para leitura; estas coisas faz com que o nível cultural seja bem melhor, diferente dos mais humildes que muitas vezes não tem condições nem de comprar um caderno para concluir seus estudos.

Portanto, acho que é injusto uma pessoa que estudou em escola pública venha concorrer com aquele que estudou em escola particular, e teve um estudo melhor, professores mais empenhados, pois ali é cobrado dos pais para que os alunos saiam dali sabendo; Já nas escolas públicas os professores gozam de muitas regalias (faltas, licenças), da qual atrapalha muito o aprendizado, fora aqueles que não fazem questão nenhuma que o aluno saia dali sabendo, e os pais ficam acoados pois o que fazer?[...]

Acho injusto a forma que funciona o ingresso na faculdade, e não é colocando cotas para pessoas negras que isso será resolvido." (1 1 a 29; 134 a 37).

Q1: “Sem diamante, escravidão

Observação: "negro no mundo dos brancos"

Pare para observar e olhe de que cor é a pele dos presidentes de empresas de grande porte, daí você vê a oportunidade de negro."

Q5: "Que a sua falta de dinheiro era problema.

A falta de dinheiro faz com que muitas pessoas de pouco caráter vão a porta de bar encher a cara e dali muitos crimes podem ser cometidos."

D210 
R: "Em um ponto de vista mais avançado a cota pode ser a solução para os afrodescendentes mostrar que são capazes de conquistar seu próprio espaço na sociedade. [...]

No meu caso faz 2 anos e meio que conclui o ensino médio e até agora não tive a oportunidade de entrar em uma faculdade por não ter condições o bastante, por isso tenho que apelar para todos os lados em conseguir fazer um cursinho pré-vestibular e cursar o ensino superior afinal vontade é o que não falta."

Q1: “O negro na sociedade em que vivemos muitas vezes é submetido há muitas coisas ruins não tendo oportunidades de entrar em universidades."

Q5: "Em nosso cotidiano temos mania de reclamar nunca ninguém está contente com o que tem mais pra isso tem que lutar pelos seus ideais não pensar só em bens materiais, mas sim em seu bem estar com uma vida digna não adianta apelar para outro lado."

\section{D169}

R: "Por mais que as pessoas digam que o negro não é discriminado isto não é verdade existe a discriminação em todo o país as vezes são julgados com pequenas coisas como por exemplo as roupas que usam numa entrevista de emprego. Se um olhar eles já são considerados ladrões.” (1 17 a 24).

Q1: “A discriminação social implica muito o negro até mesmo ao conseguir um emprego existe lugares até mesmo empresas que só tem brancos pela discriminação”.

Q5: “Um país, onde tantas pessoas desempregadas passando fome, pedindo esmolas crianças nas ruas o povo sem moradia pessoas ricas ficam mais ricas e pobres mais pobres devido a falta de crescimento com tanta riqueza em um lugar".

D173

R: "Veja bem eu quero fazer (educação física), certo se eu não conseguir entrar em nenhuma dessas universidades de graça, como que eu vou ter esse curso, sendo eu não tenho dinheiro para pagar tenho que ir tentando entrar em alguma dessas de graça." (138 a 45).

Q1: "Três meninos nascendo no ventre negro, sem cor.

Meninos sentados no chão."

Q5: "Que a sua falta de dinheiro era problema.

Hoje nos brasileiros, vivemos esse dia a dia, né a falta de emprego, dívidas e aí em diante, sem dinheiro não tem como sobreviver e sem emprego."

D175 
R: "Ao ivez de ter cotas deveriam melhorar o ensino para que todos podesem entrar na Universidade sem ter a tal da Cota, que é injusta porque se um negro presta vestibular para um determinado curso e faz 60 pontos a outra pessoa declarada Branca faz a mesma prova e tira 90 e não passa por isso é injusto, sou negro totalmente contra cotas.

Enquanto não melhorarem o nosso ensino as universidades privadas vão ficar cada vez mais rica e favorecendo a elite desse país."(1 25 a 39).

Q1: "Meninos sentados no chão, os meninos não perspequitivas de vida nenhuma para o futuro".

Q5: "Muitos tem tudo na vida e outros não. A falta de dinheiro, o desemprego faz com que as pessoas fiquem dessesperadas."

\section{D179}

$\mathrm{R}$ : "O direito do jovem de baixa renda entrar na faculdade é realmente um assunto extremamente preocupante. Pois está cada vez mais difícil um aluno terminar seus estudos em uma escola pública e logo conseguir entrar em uma faculdade pública ou particular." (1 11 a 6$)$

"Existe um outro problema muito sério em relação as universidades públicas ou não, são os negros e os deficientes físicos. São poucos os negros que frequentam uma faculdade, e quando as frequentam são a minoria. Geralmente poucos são vistos com bons olhos, e quando aceitam são pela sua condição financeira, ai todos o querem, agora quando isso não acontece eles os querem também mas pelas costas.

Já os deficientes físicos muitos passam pelo processo de seleção chegam até a universidade e param no meio do caminho pois as barreiras são muitas. A dificuldade é a falta de adaptações em escadas, salas, banheiros etc. e isso faz com que acabe com os sonhos daqueles que um dia por alguma razão, fez com o que ñ fossem iguais aos outros, mas mesmo assim não perderam a vontade de ser alguém na vida.

Termino minha redação com um só palavra "Esperança”. (139 a 59).

Q1: “O negro no país está ganhado seu espaço em, empresas, bancos e em vários setores. Um exemplo em que eu me lembro bem e me admira foi a ex-governadora do Rio de Janeiro Benedita que além de ser negra é uma mulher e fez o possível e o impossível p/ direitar o Rio."

Q5: “A periferia é isso que ele colocou e um pouco mais, jovens entrando na malandragem para conseguir mais rápido o que sonha."

D180 
R: "Eu terminei o Ensino Médio em uma escola pública que era considerada uma boa escola mais mesmo assim não me acho preparada para enfrentar os concorrentes que vieram das escolas particulares, porque eu sei que eles aprenderam mais coisas do que eu e o vestibular da USP é bem difícil e bem concorrido; mas eu não me subestimo, estou lutando para que um dia eu tenha uma chance de entrar na Faculdade e ter uma profissão. Espero que esse dia chegue não só para mim, mas para todos os jovens de periferia que como eu estão lutando para ter um futuro melhor."

Q1: "O desemprego, a falta de estudo, a falta de oportunidade para que o negro possa crescer e ser tão bem sucedido quanto qualquer pessoa branca."

Q5: “Todos na periferia querem ter dinheiro, querem usar roupa da moda, ter um carro legal. O dinheiro se faz mais importante do que a felicidade, os amigos. Quanto mais dinheiro mais poder, mais bens materiais. O tráfico é um exemplo, é uma maneira “fácil" de conseguir tudo isso e é por isso que muitos jovens vão por esse caminho.

D184

R: "O que acontece é que muitas pessoas não ingressão em uma faculdade por: sua classe social, por ser negra, etc." (1 1 a 3$)$.

Q1: "No dia atual talves uma parte dos negros ainda seja escrava, não vemos corrente ou divisão racial, mas ainda há sinais de racismo e escravidão. Poucos negros conseguem formar ou ingressar em empresas multinacionais."

Q5: "O desemprego, racismo, drogas, consumo, etc., isso gera um assassino ladrão.

As drogas viciam matam e financiam o crime organizado a continuar acabando com as pessoas. Por isso pessoas de periferia roubam para suplir vícios.”

D185

R: “As escolas com condições para aprimorar nosso conhecimento, a Faculdade hoje para muitas pessoas é um sonho difícil de se realizar, sempre temos em mente que o curso superior é para "filhinho de papai que tem condições de pagar" e ficamos desanimados, pois deixamos nos abater com essa triste realidade.’(1 10 a 15).

"Fico feliz em estar aqui hoje fazendo esta prova talvez eu não passe, mas fíco muito feliz em saber que pessoas como eu vão ter seu sonho realizado que cada um possa dar o melhor de si.

Que as chances possam ser cada vez mais aumentadas que o acesso na Universidade no Brasil seja para todos sem exceção de idade, cor ou classe social.” (1 35 a 41). 
Q1: "Quem veio por eles buscar?"

Q5: "Que as pessoas ficam em bares, reclamando por não ter emprego, sem dinheiro, ficam disiludidas e ficam sonhando com coisas que gostariam de ter e que dependem de pessoas capacitadas."

D191

R: "Espero que daqui a uns 5 anos não exista mais isso e que brancos e negros estudem em universidade sem discriminação que não tenha mais num um tipo de discriminação nem contra negros nem contra nada." (143 a 48).

Q1: “O negro em nossa sociedade sofre muito preconceito em todos os aspectos. O negro para nossa sociedade é ladrão e isso e aquilo, mas os negros estão buscando seu respeito, sua dignidade."

Q5: "Na periferia e o que mais se ve a falta de dinheiro bastante desemprego a maioria dos jovens queriam ter um carro mais como se não tem nem dinheiro para comida, quem tem sempre quer mais e o capitalismo, desemprego não só em São Paulo mais em todo lugar."

\section{D165}

R: "No meu ponto de vista acho que as universidades públicas deveria dar mais oportunidades para as pessoas de baixa renda, e não para quem tem condições de pagar uma universidade. Porque muita gente de baixa renda não tem condições de pagar uma universidade, e quando tenta ter acesso a uma universidade pública não consegue, por causa da prova que é muito difícil, e caem coisas que numa escola pública não passaram, só consegue aqueles que estudaram na escola particular, e enquanto aqueles que estudaram na escola pública fica sem ter acesso à universidade.

Com relação a cota acho que é o primeiro passo, para que vemos bem visil o tema discriminação social.

As universidades deveria permetirem mais a entrada de negros e pessoas de baixa renda sem descriminação, pois tem todo o direito de ter acesso à universidade."(1 1 a 30$)$.

Q1: "Os negros são bem discriminados pela sua cor. Muitos negros tem dificuldade de arranjar serviço nas empresas por causa do preconceito.”

Q5: "Muita gente da periferia passam dificuldades e não tem condições de comprar um carro confortável, e outros tem dinheiro para ter uma vida confortável."

D 152 
R: "Falar de educação no Brasil, é algo complicado, ou melhor, tem seus altos e baixos. Sempre existe a desigualdade. Principalmente quando se refere a uma família de baixa renda, pois esses sempre terão menas chances de mais tarde ingressar em uma faculdade, quase sempre prevalece a nota daqueles que estudaram em colégios melhores, de famílias mais ricas, ou seja, com mais condições financeiras.

Com certeza o Ministro da Educação, já deveria a muito tempo, ter quebrado essa grande desigualdade social, não somente na parte financeira, mas também de raça, se e acredito que são poucos os negros que tem chance nesse país, e principalmente de ingressar em uma faculdade, pois infelizmente vivemos em um país que discrimina o negro. O que resta é podermos acreditar e ter a esperança de que tudo irá mudar. ...

Espero que haja essa mudança de processo seletivo, principalmente nos vestibular e universidades públicas, assim todos terão seus direitos e regras por igual."

Q1: "Vejo quem vem meu leito festejar"

Q5: "É um querendo ter mais que o outro, e assim muitos perdem a vida."

D 149

R: "O Governo deveria também, procurar entre si e com pessoas capazes e entendidas no assunto, achar um melhor meio de avaliação, para ingresso nas universidades.

Algo que de direitos iguais a todos, sendo o cidadão: pobre, rico, negro ou branco.

E não pensar apenas em resolver uma parte do problema, criando cotas para negros nas universidades.

O governo deve criar universidades que passem a todos um ensino de alto padrão, para termos profissionais capacitados, pois isso é favorável ao Brasil, em relação as outras nações.

Acho dispensável um ano a mais de ensino médio, pois o que vale é a qualidade do ensino." (1 17 a 38).

Q1: "Sem diamante, escravidão

Nem pergunto pelos filhos

Ligo o rádio, durmo no colchão.”

Q5: “O que acontece nas metrópoles brasileiras, principalmente nas periferias, é a falta de emprego, que leva o cidadão ao crime, pois ele não tem como comprar por falta de dinheiro. Não tem como possuir bens e ser uma pessoa de valor."

D 145 
R: "Sabe-se que no Brasil desigualdades são extremas. E nas universidades públicas, o acesso para sua entrada não é diferente. Até porque o ensino básico fundamental e o médio não prepara suficiente o aluno.

Escolas em algumas regiões, principalmente na periferia, se tornaram em verdadeiros descasos das autoridades públicas. Não há condições, por exemplo, de professores não lecionarem, com medo dos próprios alunos. Não esquecendo o salário desses profissionais que é um desrespeito. Escolas sem a menor condição de estrutura: como bibliotecas sem livros, escolas sem carteiras e mesas, laboratórios desativados e outras dificuldades como até falta de comida.

Por isso as condições de um aluno que sai dessa escola, é quase zero para concorrer com outros estudantes de instituições particulares. Mesmo porque a pessoa que sai do ensino público e que pretende atingir, a universidade pública, esse indivíduo não tem se quer o dinheiro para a taxa de inscrição. Até porque o nível de desemprego hoje no Brasil, atinge sua grande maioria principalmente os jovens.” (1 2 a 26).

Q1: "Meninos sentados no chão".

Q5: "De que a vida do ser humano só vale quando ele tem grana".

D 143

R: "Eu, particularmente, não concordo com esse esquema de cotas e nem com o fato de a pessoa adquirir alguns pontinhos por causa de sua colocação no E.N.E.M.

O racismo existe; está diante de nossos olhos, e nós não o vemos (ou fingimos não vê-lo).

Por que eu devo ter uma cota numa universidade só porque sou negra? Os cidadãos não são iguais? Os direitos não são iguais?

Então, ou todos têm privilégios, ou ninguém tem."

Q1: “O negro hoje (como sempre), é bastante discriminado. Só que isso não é mostrado como antigamente. É só olharmos em nossa volta e veremos que quase nenhum negro ocupa cargos de chefia, "nas universidades brasileiras apenas $2 \%$ dos alunos são negros"; na televisão brasileira os negros são minoria e os lugares onde mais se tem negros é na mão-de-obra pesada nas empresas. A partir disso, acredito que nasceu negro, sofrimento em dobro."

Q5: “As pessoas da periferia têm menor poder aquisitivo, isso não é surpresa pra ninguém; porém, vivem num país capitalista, onde quanto mais se tem, mais se quer. Então com certeza essas pessoas não tem condições de consumir tudo que desejam e acabam reclamando de tudo." 
D 142

R: "Sinceramente estudei onze anos da minha vida e sempre ouvi meus pais dizendo estuda: para amanhã não precisar ficar aqui como a gente trabalhando nesses serviços braçal, para mais tarde quem sabe conseguir um emprego e quem sabe fazer uma faculdade.

E quando eu penso nessas palavras hoje eu me sinto uma pessoa inútil não é fácil no mundo de hoje ter 18 anos porque quando você tem 15 anos você pensa quando eu tiver 18 anos vou ser maior dona do meu nariz, vou trabalhar etc.

Mas quando você faz 18 anos você chega e vê que não é nada daquilo ai eu penso será que é só porque chegou a minha vez, ou as coisas é que estão difícil mesmo.

Por isso é que critico as escolas públicas e acho sim que deve haver mudanças nas universidades, mas antes se deve rever o ensino público no nosso país.

Com essas palavras não digo que os alunos do ensino público são incapazes mais sim menos favorecidos comparados aos da rede particular.

Como também digo que não sou uma pessoa burra, apesar de ter estudado onze anos no ensino público o que me falta é apenas uma oportunidade.

E também critico o ensino público pois não estamos pedindo favor a ninguém é um direito de todo cidadão que paga seus impostos.

E a respeito das universidades eu me sinto como se fosse um bebê de um ano tendo que adivinhar quanto é um mais um.”

Q1: "ligo o rádio, durmo no colchão."

Q5: “A letra da música revela mais uma vez a falta de desemprego o mano na porta do bar reclama da falta de dinheiro, enquanto ele vê o outro com carro confortável, que ele também queria ser um cara de destaque e ele diz que a sua ambição depende da tragédia de alguém pode ter certeza que ele mata."

D 131

R: "Tenho 19 anos, nasci e me criei na periferia.

Sempre estudei em escolas públicas e sempre tive o sonho de fazer um curso de nível superior em faculdade pública.

Mas quando completei o ensino médio o sonho virou ilusão, porque nunca tive um suporte de ninguém nem do governo.

Mas eu e muitos outros como eu que não tem ajuda de ninguém achamos que temos direito de termos uma universidade. 
Uma universidade que respeite o nosso nível social e cultural e nossa raça. Acho muito interessante cotas para os negros, mas não é só isso que vai resolver o problema, e não acho que é uma discriminação racial pois realmente a maioria dos negros não tem condições de frequentar uma universidade.

Não vou dizer que o pré-vestibular é a solução mas acredito que seja o começo.

A avaliação do histórico do aluno seria também importante podendo assim dar uma vaga na universidade.

O processo seletivo é legal mas parece que não é em todos os lugares que tem funcionado.

Acredito que a maior dificuldade não seja o conhecimento dos alunos mas o incentivo oferecido pelo governo que não tem como colocar alunos de classe baixa nas universidades, assim refletindo no ensino médio fazendo o aluno perder o interesse de aprender, ele pensa "pra que aprender o que vou fazer depois".

Q1: "Três meninos nascendo do ventre negro, sem cor, meninos sentados no chão, quem veio por eles buscar!”

Hoje o negro não tem classe social, vive sem amparo poucas vezes o governo se preocupa com o negro. Quem será que vai fazer alguma coisa acredito que nem Deus sabe!

Q5: “Todos na periferia almejam ter dinheiro para pagar as contas, ter uma casa mais confortável e um carro. É só ligar a televisão e você começa a querer tudo aquilo que você vê esquecendo que tudo aquilo não é sua realidade."

D130

$\mathrm{R}$ : "Na minha opinião temos que modificar o sistema do vestibular, favorecendo as classes baixas e implantando os pré-vestibulares gratuitos para a população carente que só precisa de um empurrão, o sistema de avaliação continuada é uma proposta muito boa.

Eu não concordo com a opinião do reitor Aloísio Teixeira de não haver cotas para os negros. As cotas devem continuar para insentiva-los a lutar contra o preconseito e a desigualdade social, a cota para o negro é um passo fundamental contra o preconceito. As pessoas que são contra esse sistema são preconceituosas, não querem ver o negro, lutando pela igualdade social."(1 13 a 30).

Q1: "Três meninos nascendo do ventre negro, se cor

Ligo o rádio, durmo no colchão."

Q5: “As pessoas vivem reclamando por causa da falta de dinheiro 
com a falta de recurso alguns resovem roubar e com isso muitos acabam morrendo".

D 124

R: "Os argumentos citados nos textos mostra as grandes dificuldades que tem um estudante seja ele negro pobre ou branco e pobre de ter acesso a uma universidade federal no nosso País.

Alguns textos argumentaram a falta de estrutura das escolas públicas em preparar o estudante a ingressar na universidade, e elas tem razão.

Elas tem razão pelo seguinte fato de o ensino médio não ser tão valorizado pelo governo, por as escolas hoje não possuírem materiais didáticos necessários para preparar o aluno a enfrentar o vestibular em condições de igualdade aqueles que estudaram em Escola Particular é necessário o incentivo a feitura e a participação e criação de ONG ou movimentos estudantis a ajudarem e a cobrar do governo soluções para a melhoria do Ensino Médio.

As cotas são justas porque hoje a desigualdade no Brasil é muito grande e o Ensino Médio cada vez pior e é preciso garantir que esses estudantes negros tenham a chance de ser um profissional capacitado e de ter a chance de cursar uma Universidade de Qualidade.

Eu acho que já está mudando a mentalidade dos nossos governantes de que só pessoas bem financeiramente tem condições de ter acesso a universidade. E espero que soluções como essas da Prefeitura e da Ajuda do MSU continue a ajudar os jovens pobres do nosso Estado, criando cada vez mais cursinhos Pré-Vestibulares.”(1 2 a 42)

Q1: “A discriminação contra o negro pobre no Brasil ainda é grande e acredito que o negro rico não sofre tanto preconceito quanto o negro pobre".

Q5: “O aspecto é a falta de oportunidades de emprego e de qualificação profissional e é isso que leva muitas pessoas a entrar na criminalidade."

D121

R: "Acredito que todos devem ter o direito de acesso à universidade no Brasil. Independente da cor/raça ou religião.

Nos nossos dias muitas universidades limitam o número de vagas às pessoas negras. Mas isso não é correto, as universidades deveriam deixar as pessoas passarem por seus méritos e limitar o número de vagas às pessoas que cursaram escolas particulares e que têm uma boa condição de vida. ... 
De acordo como o texto de Aloísio Teixeira, reitor da UFRJ, de 100\% inscritos na UFRJ, 70\% são alunos de escolas públicas, mas só 30\% conseguem ingressar na universidade, isso acontece pois muitas escolas públicas estão em condições precárias, não podendo oferecer um bom estudo aos alunos, que acabam desistindo de continuar a estudar.

Sendo assim, posso concluir que o governo deveria mudar algumas leis e incentivar mais o estudante a ingressar em uma universidade."(1 3 a 43).

Q1: "Três meninos nascendo do ventre negro, sem cor".

Q5: “A relação que há entre a letra da música e o cotidiano da periferia urbana das metrópoles brasileiras é que muitos para conseguir o que querem acabam cometendo a violência contra o seu adversário, querem ocupar o lugar de outro, possuir os bens de outro através da tragédia".

\section{D120}

R: "Hoje o sistema mais utilizado é o vestibular onde a aluna é avaliada por meio de uma prova contendo questões e redação. Que começamos a perceber e admitir ser inadequada, considerando a desigualdade social em todo o país. Para solucionar este problema surgiram outras formas de avaliação não contendo o formato do vestibular." (1 6 a 5$)$.

“O ENEM (Exame Nacional do Ensino Médio) seria uma ótimo substituto do vestibular. O exame possibilita a utilização maior do raciocínio do que o conhecimento específico de cada matéria, o que não acontece da mesma forma no vestibular.

$\mathrm{Na}$ tentativa de melhorar o acesso ao ensino superior, foi implantado o sistema de cotas na tentativa de diminuir a desigualdade social, pois este garante o ingresso na universidade para pessoas que se classifiquem no questionário sócio econômico do vestibular como sendo de cor negra ou parda, mesmo não atingindo pontuação equivalente a de uma pessoa classificada de cor branca.

Chegamos a conclusão que até hoje a educação em nosso país foi praticamente esquecida, sabemos que a maior parte de nossos governantes não se importa com a situação educacional, preferindo beneficiar com este descaso o ensino particular. Mantendo assim um nível fraco de ensino em todo o país já que poucos tem condições de pagar um ensino com mais qualidade e então ter formação suficiente para entrar em uma universidade gratuita." (121 a 47). 
Q1: “A desigualdade social, hoje ainda é o principal motivo de tantas diferenças que acabam gerando preconceitos. Sejam movidos pela cor de pele ou pela situação financeira."

Q5: "Na periferia, cada dia mais jovens entram para o mundo das drogas e destes muitos a maioria acaba trabalhando neste mundo, simplesmente porque acham que esta seja a melhor ou até mesmo a única maneira de crescerem financeiramente para suprir suas necessidades e a de suas famílias."

D119

R: “É inegável que o sistema de Educação no Brasil está mudando. Mas será que está mudando para melhor? Vários projetos estão sendo feitos, mas até agora os estudantes não sentiram nenhuma mudança significativa." (1 3 a 5).

Um ponto bem polêmico dessas mudanças na Educação no país é o tão comentado sistema de cotas para os negros, mostrando que ainda há um preconceito muito grande na sociedade brasileira. Se de um lado, o sistema dá uma possibilidade de cada vez mais negros ingressarem nas camadas nobres da sociedade, por outro lado deixa explícito um verdadeiro racismo enrustido, pois discrimina os negros de uma forma deliberada, e os criadores da cota inventam a desculpa esfarrapada de que os negros devem ingressar na universidade por uma questão de mérito. Mérito? As vagas já estão reservadas para eles.”(1 27 a 35).

Q1: "Poderia citar várias situações, mas uma bem marcante e que causou bastante comentários há pouco tempo atrás foi o fato das universidades darem cotas de suas vagas nas universidades para estudantes negros, mostrando que ainda há um preconceito muito grande na sociedade brasileira pois, no meu modo de ver, dar uma cota específica para estudantes negros é um racismo enrustido"

Q5: “A guerra urbana que foi destaque nos jornais nos últimos dias, em especial, na Linha Amarela, no Rio de Janeiro, onde traficantes luta contra a polícia como se estivessem num filme de faroeste, e a rota do tráfico de drogas fica cada vez mais poderosa, fazendo bandidos como Fernandinho Beira-Mar e Elias Maluco terem status de popstars, deixando bem claro o comando paralelo que existe no país, com sua periferia, infelizmente, idolatrando marginais que espalham o caos, a morte e a desgraça onde dominam. Acorda, Polícia!!!”

\section{D117}

R: "De fato, para se corrigir as polêmicas que circulam em relação a cota ou até mesmo métodos para aplicar vestibular seria necessário reeducar o país inteiro sobre 
todos os conceitos existentes, não só educação. Por ser meio complicado voltar ao passado, fica uma sugestão: "Porque não melhorar o ensino em todas as redes, seja pública ou privada, fazendo com que os alunos obtenham primeiramente respeito por seus professores pois só assim a educação - base e fundamento para tudo - pode melhorar e o ensino alavancar.

Daí então, futuramente poderá ser eliminado o vestibular de características preconceituosas e criar-se-á um vestibular do qual os alunos poderão se inscrever sendo avaliados de formas melhores através de notas escolares, rendimentos e principalmente por mérito e não ser escolhido por ser preto ou branco ou por ser rico ou pobre pois só mudando a consciência da sociedade é que se conseguirá algum progresso.

Só assim os candidatos a uma vaga em qualquer faculdade terão chances de disputar uma vaga em igualdade.”(117 a 44).

Q1: "Enquanto a sociedade estiver alimentando pensamentos como "o negro é inferior ao branco", a situação social, cultural e econômica jamais será mudada.

Cabe à sociedade mudar esse preconceito pois há muito tempo, muitos negros já provaram ser melhor que muitos brancos. Exemplos de Nelson Mandela, Milton Nascimento, Joaquim Cruz, entre outros.

Q5: "Por falta de opções sócio-culturais, a periferia geralmente apresenta o mesmo quadro: moleques brincando de bola num terreno baldio, rapazes almejando uma vida melhor, porém sempre deixando em evidência sua condição social. É difícil alcançar um objetivo sem estímulo ou incentivo".

D111

R: "Eu acho um absurdo! São humanos como qualquer um de nós, gente que quer crescer na vida e mostrar que nem todos os negros, pretos ou mulatos (com licença da expressão), são vagabundos ou bandidos." (1 24 a 29)

“Assim os universitários de outra raça não teriam vergonha de dizer "que só não entrou na universidade porque não conseguiu pontuação necessária para entra" e não pelo fato que a cota para universitários negros já tinha sido preenchida.

Deste modo teriam orgulho de disser: "sou brasileiro com muito orgulho"." (139 a 46).

Q1: "Onde os filhos que eu criei? Vida presa no quintal (...)

(...) Três meninos nascendo do ventre negro, sem cor

Meninos sentados no chão (...)"

Um elemento que ilustra a situação do negro é a desigualdade social. 
No trecho que escrevi em cima mostra uma mãe que teve seus filhos em condisões precária e acabou esperando notícias dos filhos através de um meio de comunicação.

Q5: "são pessoas que querem uma vida melhor para viver, dar para seus filhos ao parentes uma vida com conforto, pois como ele fala na última estropre a lei só é empregada para aqueles que tem poucos recursos para se defender.

Os "maiorais" crescem com as nossas derrotas."

D109

$\mathrm{R}$ : "Eu percebi que proposta não faltam para melhorar a entrada de jovens de baixa renda e de afrodescendentes para a universidade do país. Eu vejo é que falta uma postura do Ministro da Educação de assumir a realidade do estudante brasileiro. Num país onde o ensino médio é fraco e o aluno tenta competir com aqueles que estudaram sempre em escola particulares onde o ensino é forte o resultado sempre será lastimável, não dá para competir assim, é desleal para nós.

Deveríamos ter universidade para nós que somos pobres, deveriam construir universidade pública nas periferias e que as vagas sejam reservadas para estudante da rede pública e que dessem o masimo condição de que nós pudesem comcluir o ensino efetuado nesta universidade, onde o ensino seria de qualidade em todo o Brasil."(1 1 a 22).

Q1: "Vida presa no quintal"

Q5: “O seu status depende da tragédia de alguém, nunca precizamos se dar bem na vida passando por cima de tudo de alguém.”

D105

R: "Quando tratamos do tema educação nos deparamos com um diagnóstico no mínimo vergonhoso, onde maior parte da população está privada ou deficiente de algo que lhe é essencial e constrói cidadania.

O tema é amplo, envolve as políticas de ensino público, os atuais sistemas de avaliação da educação, as condições das escolas, como também o meio onde está inserida, o papel do vestibular como forma de inclusão e não exclusão social, as propostas alternativas como por exemplo as cotas para negros e o PAS (Programa de Avaliação Seriada), o ENEM e sua razão de existir, o nicho de mercado que está atraindo o ensino privado." (1 1 a 15$)$. 
"Como fora dito educação é a base, do avanço, da tecnologia, da inclusão, da cultura. Sendo alicerce não temos outro caminho se queremos um Brasil que seja de todos, a palavra de ordem é LUTA a bandeira IGUALDADE.” (1 36 a 40).

Q1: "Em minha opinião a frase "vida presa no quintal" ilustra a delimitação deste espaço e a exclusão já que lhe priva de liberdade."

Q5: "O capitalismo faz com que o consumo se torne o determinante do status social. Quanto mais se tem mais se é.

Devido a isso vimos as desigualdades sociais que geram violência, exclusão e subdesenvolvimento"

D97

R: "Força prá vencer

Acredito que ainda hoje, existem poucas chances para os alunos da rede públicas conseguir uma vaga na Universidades públicas. Pois eles saem do ensino médio muito despreparado para enfrentar um vestibular.

Concordo com a ex-secretária da educação que deveria sim ampliar o ensinomédio de três anos para quatro anos, e que esse quarto ano fosse um preparatório para o vestibular, assim com certeza iria aumentar as possibilidades dos alunos das escolas públicas, que passam para o vestibular.

Acho que também deveríamos ter mais provas nas escolas públicas que simulases, as provas aplicadas no vestibular, assim iriam a ajudar os alunos e se acostumarem desde já, a fazer essas provas sem medo, pois o medo de não saber o que vai cair, e o medo de esquecer tudo na hora nós atrapalha muito.

Tenho que discordar com o doutor em educação e professor em pós-graduação da PUC-SP, Mario Sérgio Cortella, sobre um matéria publicada no Jornal da folha de São Paulo, no dia 10-07-2003, onde ele fala sobre discriminação, não acho que as cotas separadas para negros sejam mais um passo de descriminação para com os negros, acho que é até uma ajuda, para os negros, acho ótimo pois agora até temos curso preparatórios pré-vestibular só para negros, quem sabe assim aumenta o número de negros formados, e com maiores possibilidades de vida, e poder administrar cargo alto também que hoje ainda só foram administrados por brancos.

Ajudaria também muito se o governo, criasse faculdades que só pudessem concorrer as vagas alunos de rendas realmente baixas, somente para alunos das escolas públicas.”(1 1 a 49).

Q1: "Sem diamante, escravidão." 
Q5: "Muitos na periferia, ficam também na porta do bar, muitas vezes por falta de opção, sem emprego, sem carro confortável, sem vida boa, praticamente sem nada."

D90

R: "Se um país se mede pela sua cultura, devemos buscar alternativas que visem uma forma mais coerente para que, a população de baixa renda, possa ter acesso a Universidade Pública, um sistema de avaliação continuada é uma maneira mais democrática e que feita de uma maneira concisa pode dar a oportunidade ao aluno de suprir suas deficiências ao longo dos anos, assim como de a Escola, vir a corrigir e interferir no conteúdo dos ensinamentos passados para que alunos tenham, acesso aos mesmos conhecimentos e assim ambos possam concorrer de igual para igual.

Os pais e professores, também devem desempenhar um papel importante nesse processo, para condicionar os alunos da Rede Pública de ensino, a terem um objetivo maior de conquista e não como desmotivadores e assim os alunos inicialmente veem a escola uma obrigação e não veem as perspectivas que ela pode proporcionar.

Para um início mais ágil, à princípio o sistema de cotas (apesar de polêmico), poderá corrigir inicialmente e ser utilizado, mas a longo prazo o sistema de cotas, me parece menos polêmico e traria maiores benefícios aos alunos, sendo que poderia dar a oportunidade de se sentirem preparados para enfrentar um exame vestibular sem a necessidade de ingressarem em cursinhos preparatórios.

Buscando igualar o ensino público e particular, focando o aluno a transpor horizontes e ver a escola com um instrumento de busca de conhecimentos, socialização e cultura, iremos aprimorar conceitos elevar nossa auto-estima e preparar um futuro de menos diferenças sociais e culturais.”(1 1 a 42).

Q1: “Atualmente o negro brasileiro, vivem à margem da sociedade, espalhados nas periferias, favelas, zonas rurais, alguns lutando pela falsa liberdade e outros acreditando na ausência de preconceito, os poucos que conseguiram ultrapassar essa barreira, contam que conseguiram à custa de muita humilhação e preconceito e estas pessoas, dão um brilho nos olhos de que estava desistindo da luta.

O negro deve lutar para que a cada verão o sol brilhe para cada um dos negros com maior intensidade."

Q5: “A letra da música descreve a falta de perspectiva de pessoas que desistem de lutar por melhores condições honestamente e que se veem a frente de um capitalismo desumano no qual, a distribuição é tão desproporcional, onde uns tem muito e a grande maioria tem pouco." 
D87

"Não concordo com o método de vestibulares nas universidades, pois, pessoas de maior renda, que estudaram em escolas particulares e estão fazendo cursinhos particulares, sempre estarão na nossa frente. Pare e pense, o nível de ensino em escolas públicas está muito baixo, existem várias pesquisas que não me deixam mentir, alguns professores estão despreparados e sem contar o noturno e o supletivo que o ensino é bem mais corrido.

Diante dessas afirmações tem como uma pessoa de baixa renda, concorrer no vestibular com outra pessoa mais favorecida que ela?"(1 1 a 12).

"Em relação a cotas para negros, não acho certo, da mesma forma haveria uma forma de pré-conceito para com eles. Fizeram uma pesquisa no fim do ano passado onde nem um terço dos alunos eram afrodescendentes nas universidades, onde deveriam ser quase metade." (1 19 a 23).

"Enfim vamos continuar lutando por direitos iguais e sem desigualdades sociais e raciais nas universidades, pois, SOMOS O FUTURO DA NAÇÃO...” (1 54 a 56).

Q1: “Algumas pessoas conseguem afirmar que não existe mais racismo, não é verdade lógico comparando com muitos anos atrás agora o número de racismo é menor, mas não acabou temos que continuar lutando contra isso.

E ainda hoje dizem um negro correndo é ladrão, e um branco é atleta, não acho isso direito.

Racismo é crime..."

Q5: “Sabemos que as coisas estão ruins não só para nós, mas pra todos, não temos como ajudar, a vida na periferia é uma competição diária e por mais que você não queira e não possa terá que sobreviver e sempre terá que passar por cima de alguém.”

D61

"Sou contra em ampliar para quatro anos o ensino médio, por que se em três anos não se conseguem preparar o aluno para o vestibular não será em quatro, as escolas públicas não tem estrutura o suficiente para isso.

Tem que acabar com o vestibular que exclui os Estudantes de escolas públicas que moram nas Periferias, que não tem condição de pagar ETAPA e Objetivos etc...

O que ganham mal dá p/ seu próprio sustento.

Não tenho claro ainda a melhor maneira de avaliação para o ingresso na universidade pública. 
Enquanto as cotas, concordo com Mario Sergio Cortella, não por tornar apenas visível esta discriminação pois isso é fato está no dia-dia e mais do que visível, mas e sim um resgate uma divida (historicamente), com os negros e afrodescendentes, Pois o negro é visto como o marginal.

Pelo fim do vestibular e acesso permanente na universidade pública que é um direito de todos."(1 15 a 42).

Q1: "Descriminação, desigualdade social."

Q5: "Ela retrata uma parcela do ocorre na pereferia, onde vale a lei do mais forte, o seu status depende da tragédia de alguém."

D20

R: “As autoridades deveriam seguir a lei que todos os brasileiros devem ter educação e o governo tem a obrigação de colocá-la em prática.

Outro sistema de avaliação que poderia ser utilizado pelo ensino superior seria a renda per capita de cada estudante, criando cotas destinadas a esse fim.

Não podemos esquecer daqueles que já terminaram o ensino médio e não teve a oportunidade de estudar em uma faculdade criando programas de cursos prévestibulares gratuitos.

As instituições particulares poderiam focalizar algumas vagas para a população mais carente com bolsas de estudo totalmente gratuitas, e não criando cursos e carreiras que prometem formação imediata.

Sobre as cotas para negros nas universidades não resolve a exclusão no ensino superior, surgi sim uma desigualdade social no país, que desaparecerá com os sistemas de avaliação aqui citados, e ocasionando maiores oportunidades para os afrodescendentes.”(1 1 a 41).

Q1: "Infelizmente o elemento que ilustre a situação do negro é a desigualdade tanto econômico, como social, político pelas poucas oportunidades há eles direcionado,"

Q5: “Um exemplo prático são as moradias construídas de madeiras na periferia urbana. A diferença da renda causa essa diferença entre os brasileiros."

\section{D14}

$\mathrm{R}$ : "Eu não concordo com o sistema de cota, pois acho que ela mantem o vestibular e por isso causa bastante desigualdades." (1 2 a 4 ).

"Gostaria de deixar claro que sou descendentes de negro e já sofri muitas discriminação, mas não acho que um negro entrar para uma universidade pública é questão de mérito, acho que é questão de ser cidadão e todo cidadão tem por direito 
querer entrar $\mathrm{p} /$ universidade e seguir os caminhos que escolheu para sua vida. Ou será que por ser negro não tem o direito de buscar seus interesses e seus próprios direitos como cidadão?” (1 19 a 26).

“O governo desse país deveria assim como muitas pessoas se conscientizarem que nós cidadãos temos não só deveres e sim direitos também, pois somos jovens e merecemos ter oportunidades de pelo menos tentar mudar um pouco desse nosso país, mas para isso precisamos de estudo e muita força de vontade.

Força de vontade eu tenho, mas já que isso tem a minha fé, só me falta o direito e eu vou lutar por uma universidade gratuita." (1 42 a 50).

Q1: 'Três meninos nascendo no ventre negro, sem cor'

“Tiro por essa frase que o negro hoje em dia já é discriminado desde o próprio ventre da mãe, a partir do momento que começa a ser gerado. Ao nascer, geralmente não tem nem roupa p/ vestir direito, a partir daí a criança negra cresce, numa sociedade pobre, onde a própria criança acaba se rejeitando a si própria por causa das consequências da discriminação social e racional."

Q5: "A letra da música relata o cotidiano muito real fala a respeito do homem que está desempregado, e hoje isso é muito comum no Brasil. A falta do emprego acarreta muitos problemas, um deles a violência, o roubo. Às vezes a falta de dinheiro leva um cidadão cometer alguns delizes. Ainda mais quanto alguns tem muito e enquanto outros não tem nada. Esse é o pais capitalista que em qual vivemos cheio de desigualdades sociais."

\section{D13}

R: "Concordo com Eunice Ribeiro Durham Texto 4.

Quando ela diz que acha errado o sistema de cotas, e que devemos melhorar antes de ingressar na faculdade.”(1 1 a 5).

"Por isso que concordo que temos que melhorar antes de ingressar na faculdade ela deu uma grande ideia como criar cursos pré-vestibulares gratuitos, dessa forma estará preparando o jovem e capacitando ele a ingressar em uma universidade sem que ele fique perdido e venha a perder a vaga." (1 14 a 21).

"Não adianta aumentar mais um ano no ensino médio se continuar do mesmo jeito. Se usarmos esse quarto ano como cursinho assim valerá apena aumentar mais um ano.“ (1 42 a 45).

Q1: "Muitos criticão os negros e achão que se sobreçaem sobre eles. Por eles terem sido escravos e que só prestão para servir os outros. 
Até mesmo nas nossas emissoras de televisão quando aparece um negro, é empregada doméstica.

Temos que começar a mudar por ai que é onde o brasileiro mais se concentra senão não vamos mudar nas ruas.”

Q5: "Que por não fazer, que seu meio de vida mudase ter vivido sempre na mesma rotina, começa a desanimar e só passa a reclamar da vida."

D12

R: "O programa de Avaliação Seriada O PAS, criado para a substituição do Vestibular, que já é usado na UNB pode se estender em seus limites. Mas neste ponto que o "Ministro da Educação Cristovam Buarque" considera estender penso eu, que ele queira se estender de forma outra assim como se externa a política externa, pelos seus analistas. 1 A Constituição do Espaço Nacional. O programa será Constituido em todo o Espaço nacional? É catalogado? 2 A Consolidação do Espaço Nacional, este programa pode não estar bem firmado, bem consolidado, pode futuramente frustrar estudantes deixando-os, "Complexados". Uma consolidação de um projeto leva em si muitos anos para ganhar, conquistas nacionais, reconhecimentos e vitórias."(1 16 29).

Q1: "Os tempos de Fecundas transformações por que passa a sociedade brasileira, vem se transformando em uma lacuna de impressões, refiro-me a questão étnica. Um dos elementos, ilustre da situação do negro é bruscamente a sua integração Racial na sociedade, a sociedade ainda vê o negro como uma pessoa, um indivíduo que não tem capacidade para, "enriquecer" a sociedade, "ajudar" a sociedade. Creio eu que o negro se compara "só" na sociedade. Como o texto diz: "Vejo quem vem meu leito festejar, três meninos nascendo do Ventre Negro".

Vemos que somente ela e seus filhos. É somente um dos elementos da integração Racial no Brasil, que chega ao seu "status-quo"..."

Q5: "Visivelmente vemos este aspecto do Cotidiano da periferia Urbana das metrópoles brasileiras, com os seguintes aspectos. Todos em uma periferia, gostariam de ter uma casa, um carro confortável, mas ñ tem condições; e procuram de todas as formas solucionar este dilema é aonde passam, a roubar e a matar..." O seu status depende da tragédia de alguém".

D2

R: "[...] O sistema de cotas, talvez não seja o ideal para a comunidade negra como um todo. Mas, temos que tratar desigualdade com desigualdade, só assim chegaremos à igualdade. Os problemas existem há muitos anos e precisa de mudança. 
Para isso, tem que começar de algum modo. Talvez, as cotas não resolvam as desigualdades existentes no país, mas, com certeza absoluta irá diminuir a distância que existe entre os povos de nosso país." (1 12 a 21).

Q1: “O negro está cada vez mais longe de uma vida digna. Existem muitos filhos sem pai, sem ter o que herdar. $\mathrm{O}$ negro está abandonado à própria sorte, esperando que o mundo seja um pouco melhor."

Q5: “A mídia a todo momento dita o que vestir, o que comer, com que andar e aonde ir e com que carro. Só que a realidade da periferia é outra, pois, o salário não dá para comprar tudo aquilo que você. E algumas pessoas tem a mente mais fraca e acaba caindo na marginalidade".

D17

R: "Tratar da educação implica em levar em consideração, pelo menos, dois aspectos relevantes: o aspecto social, como padrão de desigualdade e a questão do preconceito, seja ele de cor, classe social, raça, costumes, etnias ou tantos outros existentes, tão impregnados em nossas raízes e cultura.

O sistema de cotas, como processo de seleção para o ingresso nas carreiras acadêmicas, é imparcial e extremamente preconceituoso. Na mesma proporção em que ele aumenta a oportunidade de formação superior à pessoas com realidades sociais críticas, ele subjuga a capacidade de desenvolvimento, tanto intelectual (Inteligência), como emocional (auto-estima) do candidato.”(1 2 a 17).

"Reestruturar o sistema educacional, reciclar os profissionais da área e dar condições de desenvolvimento para nossas crianças, significará depositar nossa crença e confiança nas mãos desses futuros profissionais. Aí sim, verdadeiramente, teremos dado um grande passo para a motivação de um mundo mais igualitário e suportável de se viver.

Um mundo, uma humanidade melhor, é possível sim.

E eu acredito.”(1 38 a 48).

Q1: "Pode-se exemplificar a situação do negro quando falamos de status social. É raro vermos negros em cargos de diretoria, frequentar escolas e clubes de elite, ascendendo politicamente, dentre outros."

Q5: “O descontentamento ante a falta de posição social e a implicância disso em má qualidade de vida, em falta de poder aquisitivo, retrata um aspecto do cotidiano da periferia urbana das metrópoles brasileiras".

D16 
R: "Todo cidadão tem direito de engressar em uma universidade: jovens e velhos, brancos e negros, ricos e pobres, mas o que podemos ver hoje em dia é que a maioria dos que conseguem entrar em uma universidade pública, pertence a classe média-alta da sociedade e a maioria que entra em universidades particulares são de classe média-baixa. Isso não deveria ser ao contrário?” (1 1 a 11).

"Sei que o sonho da maioria dos jovens (a começar por mim) é fazer uma faculdade e se tornar um grande profissional, mais hoje em dia para jovens como nós de classe média-baixa restam duas opções.

1.Entrar em uma universidade particular e ter que estudar tendo que fazer acordo todo mês na secretaria porque não tem condições de pagar ou

2. Entrar em uma Universidade Pública como USP ou Unicamp ou Unesp e etc.

Eu como uma jovem que sempre estudou em escolas públicas e que desejo fazer uma faculdade e não tenho condições de pagar, agradeço a Deus por Universidades Públicas e por cursinhos como o MSU, que nos dá mais chances de entrar em universidades públicas e realizar nossos sonhos.”(1 30 a 52).

Q1: "O negro tem sido muito descriminado na Sociedade, apesar de isso não ser muito aparente. Tem difícil acesso a empregos, a estudo e até mesmo à vida, podemos ver nas grandes e pequenas favelas, a maioria dos moradores são negros.”

Q5: "Muitas pessoas na sociedade da periferia está sem trabalhar, querem comprar coisas e não tem dinheiro e querem ser "pessoas de destaque", isso leva a maioria a cometer crimes com roubo. OBS: Não quero justificar o fato das pessoas roubarem."

\section{D37}

R: "A faculdade é um sonho, não mais do que isso um devaneio, para muitos que sonham um dia ter uma formação superior." (1 11 a 3$)$.

"Foi estabelecido nesse último ano um sistema de cotas para estudantes negros, que acabou causando uma grande repercussão, os alunos que se declararam negros, dependendo da escola que frequentam pública ou privada, já tem cotas de vagas, isso causou revolta dos alunos que se dizem-se brancos.

O sistema de cotas na minha opinião não ira funcionar já foi feito nos EUA e não teve um bom resultado.

Dependendo do aluno (existem também negros ricos poucos mas a maioria e pobre) a faculdade perde muito, porque seus estudantes não são qualificados e no final a 
grande maioria não acompanha o curso, acabaria resultando na repetência em massa e o curso perderia qualidade formando profissionais deficientes.

Mesmo assim sou a favor das cotas, com algumas mudanças as cotas seriam para alunos que estudaram em escola pública não importando se forem negros ou não.

Haveria também uma linha de pontuação, para não serem aprovados alunos com notas muito inferiores e se não houver preenchimento está cota iria para estudantes que não estavam escrito no sistema de cotas."'(1 32 a 52).

Q1: “É um fato o fim da escravidão, como diz na canção 'me falando do seu tempo. Conta a idade, conta o que restou' a escravidão acabou mas entramos em outra escravidão quase tão pior quanto a outra, a do preconceito e racismo. Como diz no trecho final 'nem pergunto pelos filhos Ligo radio e durmo no colchão'. Isso mostra que há um preconceito muito grande em relação ao negro, tudo o que acontece de pior é relacionado à sua cor negra, há também dados que provam que apenas $6 \%$ de negros fazem faculdade. Isso é uma escrusão social.”

Q5: “A periferia é um lugar de muitos sonhos, de pessoas que desejam uma vida melhor, ter alguma esperança, mas se sente e são escruidos por uma sociedade capitalista que deseja o lucro e não o bem estar do trabalhador e população.

Esta é a minha opinião.”

D51

R: "O Vestibular, processo seletivo para o ingresso no ensino superior, tem como meta selecionar os mais aptos, segundo as diretrizes de ensino, entre todos que prenteiam as vagas. Fato esse inquestionável, se o ensino nacional tivesse uma grade Curricular uniforme e igualitária entre as instituições educionais.” (12 A 6)

Não adianta resolver a situação em pontos isolados, deve-se corrigir no todo, desde a adubação do terreno, para que a raiz possa tirar os nutrientes do solo e assim essa árvore produzir frutos, que serão sementes e Constituirão uma nova sociedade, igual e sem preconceitos. Para isso precisamos sair do papel e começar a agir. (1 38 a 43).

Q1: “O negro na maioria, maciça, dos casos é discriminado no mercado de trabalho, se sujeita a receber salários menores e é desmotivado pelo espírito de inferioridade que visam implantar nele. Fato este materializado nas grandes carreiras como medicina, engenharia, inteligência artificial, que não são seguidos por estes e pela grande parcela destes em Carreiras de âmbito Social, tais como assistência social, enfermagem. Muitas vezes essa desmotivação também é demostrada pelos filhos que 
não aceitam a sua cor e a cor de seus pais, esquecendo assim, que interiormente não temos cor e somos todos iguais".

Q5: "Seu nível de status depende de "ter" e não de "ser". Não há tanta preocupação em ser alguém de caráter, com conhecimento e cultura. A nova ordem é $\underline{\text { ter, }}$ quanto mais eu tiver, mais eu sou, mais eu quero, não importando se tenho que devorar alguém. O Consumismo avassalador, seja por moda ou vaidade, descaradamente ou sutilmente implantado pela mídia fez com que esqueçamos de nós mesmos e no final percebemos que não somos nada, somos marionetes capitalistas."

D85

R: "Como podemos ver, a nossa sociedade é bastante democrática, pois não temos o direito de realizar os nossos objetivos. Pois acham que muitos jovens não tem capacidade sequer de um dia aprender, pois não dão oportunidade.

Eles tem medo de nós não conseguirmos encarar uma faculdade da vida, por que lá trás não tivemos uma boa condições de aprendizado. No texto $\underline{5}$ diz o seguinte "Não adianta selecionar um aluno que depois não conseguirá acompanhar bem o curso", eles nem deram oportunidade para o jovem e já vão descartando muitos jovens. “infelizmente o Brasil é assim”.”(1 1 a 16).

"Ps: Mas eu jamais deixarei de lutar por meu objetivos, por mais que sejam difíceis!!!

Vale a pena viver em busca de sonhos "Viva esse sonho". (1 55 a 59).

Q1: “Até hoje existe esse sofrimento da mulher negra que trás no texto, só o fato de eu trabalhar com as mulheres que sofrem violência domésticas; imagine as negras; muitas vezes elas tem vida presa no quintal da própria casa".

Q5: “A letra dessa música é uma das realidades em que muitos jovens vivem, não conseguem trabalho, acabam nas bebidas, drogas; E acabam achando que nunca é capaz de crescerem na vida. E acham que a vida que é selvagem; e sempre nascendo o capitalismo."

D75

$\mathrm{R}$ : "O acesso as universidades públicas no Brasil é restrito ao conjunto de pessoas que tem o privilégio de ter boa situação econômica. Essa situação privilegiada garante, entre outras coisas, o ingresso em boas escolas particulares e acesso a cursos pré-vestibular." (1 4 a 9).

"O sistema de cotas garante o ingresso na universidade. O que fazer para recuperar o atraso provocado por uma educação precária?" (143 a 45). 
Q1: "O elemento pobreza é o mais significativo na situação dos negros na sociedade atual; a pobreza e as consequências causadas por ela."

Q5: “A diferença social é um problema para, se não todos, a maioria das pessoas. A falta de recursos para dispor de necessidades básicas tais como moradia, saúde e educação é uma questão séria; mas dispor somente disso não é o bastante. Existem necessidades culturais, lazer, etc."

D78

R: "O vestibular a muito tempo é um sistema de avaliação ultrapassado. É claro que não competem com igualdade no vestibular de universidades públicas, estudantes de baixa renda e de classe média, a começar pela diferença entre escolas públicas e escolas particulares, ambas possuem métodos de ensino completamente diferentes e as escolas de nível médio particulares tem muito mais capacidade de preparar seus alunos para ingressarem no ensino superior.

É evidente que a mudança deveria ser feita no ensino médio, ao invéz de ser feita já no ensino superior, porém isso levaria muito tempo, caso as mudanças fossem feitas hoje com alunos de escolas públicas da 8 série, levaria cerca de 4 anos para saber se eles irão competir com igualdade no vestibular, mais três anos para saber-mos se eles conseguirão acompanhar o curso sem que a instituição perca a qualidade de ensino e mais uns dois anos para saber-mos qual será a posição desse profissional diante do mercado.

Em média levaria-mos 10 anos para começar-mos a enchergar algumas mudanças. Porém é necessário algumas mudanças imediatas, para ter-mos resultados imediatos.

Por isso sou a favor das cotas para negros na universidade, acho que seria um bom começo, daqui 4 ou 5 anos já teríamos uma mudança bem visível com relação aos afrodescendentes no mercado de trabalho e consequentemente na sociedade como um todo.

Pode até ser que o processo de cotas façam com que algumas pessoas com deficiência na educação cheguem até a universidade e desistam por não conseguir acompanhar os outros alunos, mas em contrapartida fará com que muita gente realmente esforçada chegue até lá e diante do curso se desenvolva tão bem que se tornará um ótimo profissional. 
Ou então as duas mudanças (as cotas e a partir da 8 série) podem ser feitas simultaneamente, assim teremos soluções boas a curto prazo e soluções melhores ainda a longo prazo, o que não pode é não ser feito nada.”(1 1 a 44).

Q1: “A abolição foi assinada mas os negros não foram totalmente libertados, deixaram de morar em senzalas para morar em favelas, continuam servindo os brancos e em troca ganham um salário que não dá sequer para as necessidades básicas. Não são mais prisioneiros, podem sair de casa, porém não tem para onde ir."

Q5: "Na sociedade consumir é necessário sim, como se você valece o que tem, e algumas pessoas de baixa renda, não tendo oportunidade de ser bem sucedido, viram bandidos para poder enfim ter o que a propaganda mostra. E na maioria das vezes alguém tem que morrer para isso acontecer."

D40

R: "Podem dizer que se trata de racismo ou até mesmo exclusão social mas não se trata disso. Vão continuar discutindo enquanto não perceberem que estão errados em relação a tudo o que dizem e que não é necessário cotas, é preciso melhorar o ensino público, porque acredito que o fato de estar separando vaga por etnia, situação financeira ou social já soa como discriminação pois se não é para haver discerssão de pessoas a questão não está no tanto de vagas que uma universidade mantém separada para pobres e negros e sim na preparação que estes tiveram para competir de igual para igual independente de sua situação social ou financeira".(1 9 a 27).

Q1: “Apesar de ainda hoje haver "pessoas que discriminam as raças, o negro hoje é bem aceito na sociedade. Acredito que a diferença de antes para agora é que a discriminação está sendo abolida das ruas, mas ainda continua dentro de muitos, e só reparar em algumas "piadas"."

Q5: “Os “jovens” de hoje se enquadram na posição em que esta musica coloca. Porque para não serem excluídos do grupo, compram e fazem qualquer coisa para comprar "artigos" que os fazem parecer incluídos nos grupos. A ideologia que eles "recebem" e "interpretam" como se fossemos "bonecos" e que devemos seguir e fazer tudo igual aos outros.”

D41

R: "As cotas deveriam existir para esses casos:

Alunos que estudaram a vida toda em escola Pública ou Municipais, e que comprovassem baixa renda. 
Porque se você cria cotas para negro ou afro-descendente, daqui algum tempo terá de criar para japonês, judeu, italiano e assim por diante."(1 14 a 23).

Q1: “O negro na verdade ele ainda não é livre. Mas o preconceito maior as vezes e ele quem coloca. Exemplo:

Quando dizemos aquele negro bonito.

Ele diz:

Negro não. Moreno.

Quando acabarmos com esse preconceito de o negro ser submisso, e o próprio parar de se discriminar talvés viveremos melhor."

Q5: "Bom a letra diz que aquela pessoa que fica em frente o bar vendo as outras pessoas passar, vê uma que cresceu e deu certo, outra com um bom emprego, e consegue comprar tudo o que quer.

Ele fica desesperado porque ele tem que consumir e não há dinheiro nem emprego para isso."

D23

R: “A condição de criar cotas para negros são desfavoráveis pois "-Não é a cor da pele que diz se você é inteligente ou burro" e sim a classe social que pode influenciar em seu desenvolvimento.”(1 18 a 21).

Q1: "Elemento: Abolição + a distância econômica, social e política"

Q5: “A DIFICULDADE p/ uma pessoa de baixa renda faz com que ela "sonhe" com o consumismo e queira ter tudo bom e do melhor como não tem qualificação na maioria das vezes parte para a marginalidade ("o dinheiro Facil”)."

D114

R: "Acho que o sistema de cotas é viável sim, e deveria existir um tanto de cotas específico tanto para negros como para brancos.

Como uma porcentagem de 50\% para cada, e deveria também fazer uma investigação na vida de cada pessoa, que se inscrevesse no vestibular. Porque, aí, sim, você saberia quem é negro, e quem, é branco. Quem tem condições de pagar uma faculdade particular, e quem não tem condições de pagar.

Essa investigação, que eu digo, é baseada na renda econômica de cada aluno.

Esse tipo de sistema, sem, ser o das cotas para negros, para mim, não quer dizer, que não seja um bom sistema, é um bom sistema sim, mas não acho o mais provável.

Mas acho o sistema de cotas o mais apropriado, assim não teria mais o problema de desigualdades." (1 15 a 33). 
Q1: "Três meninos, nascendo no ventre negro,

Sem cor meninos sentados no chão

- Quem veio por eles buscar!"

Q5: “A letra da música fala da situação atual em que vivemos. Há falta de emprego pessoas querendo ter bens materiais, mas não conseguem honestamente, devido a falta de emprego e não tem outra saída, se desesperam e vão roubar.

Então a vida na periferia é difícil ainda mais no Brasil com esta crise financeira." D261

R: "Não obstante, notícias sobre a implantação de cotas para estudantes negros, causaram um certo impacto na sociedade brasileira devido a diferentes opiniões. Porém, o que realmente precisa ser esclarecido é que somente dessa forma radical, os nossos estudantes negros puderam competir entre as diferentes carreiras universitárias destinadas quase que exclusivamente aos brancos.

É inegável que essa atitude é a mais adequada para o ingresso de negros nas universidades públicas, mas somente assim de maneira radical, o estudante conseguirá o seu espaço."(1 24 a 35).

Q1: 'Três meninos nascendo do ventre negro sem cor'

"O verso acima ilustra o preconceito racial na sociedade brasileira, pois se ao nascer, a sua cor for diferente da branca, o seu futuro será comprometido pela miséria, pois não conseguirá brincar, estudar, trabalhar, enfim, tudo aquilo que os outros fazem, por causa do fantasma do preconceito."

Q5: "Viver numa sociedade capitalista se torna cada vez mais difícil, particularmente para aqueles que vivem em situações precárias. O poder de consumir, levam milhares de pessoas a um certo grau de loucura, pois para poder satisfazer suas necessidades, estas cometem crimes e são julgadas pela mesma sociedade que a condenaram."

\section{D123}

Q: "Quanto ao tema cota para negros, não concordo da forma que é apresentada, é claro que são maioria, mas não são os únicos excluídos, existem brancos que também são carentes. Acredito que ações como essas, que tendem a favorecer só um determinado grupo só vão trazer dor de cabeça e mais discriminação. O correto, seria primeiro expandir a ideia para todos os tipos de carentes, sejam eles negros ou brancos, segundo não ser aplicado na metade das cotas e sim como um critério de diferenciação. Por exemplo no caso de empate na pontuação do vestibular, nesse caso teria a vantagem 
quem for carente, pois se continuar na metade atual de cotas, com toda a certeza a qualidade do ensino vai cair e em certos casos será apenas mais um com diploma nas mãos e não um profissional formado.”(15 a 28)

Q1: não respondeu.

Q5: "Lamentavelmente isso que foi dito é uma verdade e muitas vezes mesmo pra quem trabalha é difícil conviver com um fato inegável, a "moda" não digo somente em termos de roupa, mas em geral, faz com que nos sentimos menos pessoas, quando não podemos comprar um tênis ou uma roupa de marca por exemplo. É muito difícil conviver com situações como essas, e isso acontece em vários sentidos, hoje algo pior está acontecendo, e isto é, a exigência de um corpo belo cada vez mais."

D235

R: "Quando se fala de saber quem tem mais mérito, se é o estudante de escola pública que tira nota 6 ou o de escola particular que tira nota 8 , realmente, não há como se dizer, considerando-se as condições de formação escolar de cada um." (1 23 a 29).

Não sou totalmente contra o sistema de cotas, pois estas seriam uma maneira de tentar diminuir as desigualdades sociais e raciais na hora de ingressar no ensino superior. Mas acho que as desigualdades sempre irão existir enquanto todos os conceitos e critérios educacionais não forem revistos."(1 42 a 50).

Q1: “Apesar de estar diminuindo, a discriminação racial no Brasil ainda é grande, pois a maioria dos empresários, executivos e donos de empresa são brancos. A porcentagem de negros no ensino superior também é ínfima.

Enquanto não houver melhores oportunidades e menos distinção racial e social, isso nunca irá acabar."

Q5: “A falta de condições de vida dignas e falta de oportunidade vivida diariamente pelos jovens da periferia e realidade inversa vivida pelo jovens ricos, mostrada na maioria das vezes pela televisão, são fatores que levam a juventude da periferia a ter o tipo de pensamento citado na música."

D236

R: "Outros que sofrem injustiças são os afrodescendentes, que na maioria das vezes também moram na periferia e não terem bagagem suficiente para enfrentarem o vestibular e o de serem da raça negra que apesar de quase a metade dos nossos cidadãos brasileiros serem afrodescendentes ainda sofrem com o preconceito.” (1 10 a 20).

Q1: "Eu acredito que ainda exista esse tipo de preconceito a respeito da raça negra pelo seguinte fato a maioria dos crimes, assaltos, roubos, são feitos pelos 
adolescentes da raça negra, que sabendo que estão nas estatísticas continuam se envolvendo no mundo do crime.

Q5: “Os jovens da periferia dão muita importância em estar bem vestido ter carro, moto.

Eu acredito que parte disso seja pela falta de conhecimento, mas não coloco toda a culpa em nossos governantes pois existe muitos jovens que não sabe aproveita as oportunidades que tem."

D243

R: "Talvez se o sistema de avaliação do ensino médio (ENEM) fosse modificado e as universidades adotassem o ENEM como acesso a qualquer curso na universidade seria muito melhor para nós estudantes. Porque acho que o ENEM é só uma forma que o governo encontrou para desviar as atenções do precário "mundinho" da Educação que é falhido e sem esclúpos.

Será que vamos continuar com essa bobagem que apenas uma pequena porcentagem de pessoas de cor negra entram na universidade sendo que na constituição está escrito que todos somos iguais, que temos direitos e deveres, então eu te pergunto por que maltratar as pessoas negras?

Não quero facilitar a entrada de uma pessoa negra no vestibular, mais deixar a disputa mais justa no ingresso a uma boa educação em escolas, cursos e etc. Não só os negros, mais para uma imensa população menos privilegiada que somos o povo brasileiro.

Ou será que a burguesia acha que a população mais humilde não tem direito de ingressar a uma boa universidade, que só pode entra os "filhinhos de papais"."(1 18 a $34)$.

Q1: "Sem diamante, escravidão."

Q5: “'Você viu aquele mano na porta do bar' Quer dizer, uma pessoa sem nenhuma atividade de lazer na periferia, sem um carro para levar a família para passear nos finais de semana a um parque por exemplo, e que seu status é ser um "Tarzan" na terrível selva urbana em que vive."

D260

R: “A cota, com certeza tem seus pontos negativos (como tudo na vida), porém em minha opinião é o único recurso que no momento temos na mão para garantir o ingresso de alguns a universidade. 
Porém não devemos desanimar, nem muito menos regredir, a idéia central dada como base é reunir nossas ideias que facilitem o ingresso de "todos" a universidade e torná-las assim parte de nossa realidade, pois estamos em um país democrático e todos nós temos o direito a uma vida descente."(1 24 a 35).

Q1: "Tenho como elemento, uma coisa bem clara a DESIGUALDADE que existe."

Q5: “A letra esta relacionada diretamente ao cotidiano da periferia, pois muitos vão em busca de seu status através de "dinheiro fácil" imaginando assim conseguir tudo o que julga ser necessário (carro, celular, enfim ser "o cara"). Porém sabemos que a realidade não é esta que o capitalismo esta ai, claro, comprar é necessário, porém a selvageria nos tira a liberdade, nos tira o nosso tão precioso sono."

D261

R: "Não obstante, notícias sobre a implantação de cotas para estudantes negros, causaram um certo impacto na sociedade brasileira devido a diferentes opiniões. Porém, o que realmente precisa ser esclarecido é que somente dessa forma radical, os nossos estudantes negros puderam competir entre as diferentes carreiras universitárias destinadas quase que exclusivamente aos brancos.

É inegável que essa atitude é a mais adequada para o ingresso de negros nas universidades públicas, mas somente assim de maneira radical, o estudante conseguirá o seu espaço.”(1 24 a 35).

Q1: 'Três meninos nascendo do ventre negro sem cor'

"O verso acima ilustra o preconceito racial na sociedade brasileira, pois se ao nascer, a sua cor for diferente da branca, o seu futuro será comprometido pela miséria, pois não conseguirá brincar, estudar, trabalhar, enfim, tudo aquilo que os outros fazem, por causa do fantasma do preconceito."

Q5: "Viver numa sociedade capitalista se torna cada vez mais difícil, particularmente para aqueles que vivem em situações precárias. O poder de consumir, levam milhares de pessoas a um certo grau de loucura, pois para poder satisfazer suas necessidades, estas cometem crimes e são julgadas pela mesma sociedade que a condenaram."

D262

R: “Que programas de cotas para estudantes negros, de origem indígena e pobres não resolvem as causas sociais do problema, também estamos carecas de saber. Não é preciso ser Reitor da USP para saber isso. 
O que, na minha opinião, deveria ser revisto é o papel da própria universidade no problema. As instituições de ensino são omissas. Tudo o que fazem é criticar as iniciativas para democratização do ensino superior público.

Elas deveriam atuar junto as comunidades carentes. Poderiam desenvolver os chamados programas de cotas fazendo-os evoluir, identificando as deficiências dos candidatos carentes e auxiliando-os a se tornar aptos a ingressar na instituição.”(1 25 a 41).

Q1: "De acordo com dados que extraí da internet, hoje menos de $15 \%$ dos estudantes que se formam nas áreas de tecnologia são negros. De acordo com o veículo, os alunos negros não procuram essas áreas por temer a descriminação do mercado de trabalho. Hoje o mercado de trabalho nas áreas tecnológicas evitam contratar profissionais negros independente da formação acadêmica."

Q5: "Hoje em dia, em um bairro da periferia da Zona Sul de São Paulo, existe um posto de consumo de bebida alcoólica (BAR) para cada 12 habitantes de acordo com o site da Folha de São Paulo na internet.

Assim chego a conclusão de que o álcool, por ser a droga lícita mais barata é a mais consumida nas áreas mais carentes."

D282

$\mathrm{R}$ : “O sistema de cotas para negros não resolveria grandes coisas, é verdade que o negro na universidade pública é minoria mas esse sistema serviria para evidenciar que o negro não tem condições de competir igualmente com os outros e aumentaria ainda mais a discriminação. É fato situação de que os negros são mais pobres, mas pessoas brancas, indígenas, japonesas...pobres o que lhes seria feito?" (130 a 37).

Q1: “O negro vive em uma situação de falta de oportunidade, isso é reflexo da escravidão, infelizmente. Quando houve a libertação dos escravos, os negros não tinham nada e não houve quem os ajudasse. Com a soltura dos negros, as lavouras ficaram sem mão-de-obra, então o governo ao invés de dar oportunidade de trabalho aos negros, não deu, preferiu os imigrantes. Com o avanço da indústria o Brasil carecia de mão-de-obra, mas o Brasil em sua ignorância continuou recorrendo aos imigrantes. Se desde essa época fosse dado o direito e a oportunidade, possivelmente as coisas seriam diferentes."

Q5: “As pessoas que vivem na atualidade muitas vezes não olham para o seu próximo, a ganância e a ambição detonam o valor humano. Então as pessoas para serem reconhecidas precisam de posse, status, o que as faz querer o poder de todas as formas 
não importa a quem irá ferir. Essa face do capitalismo torna as pessoas respeitadas não pelo que elas são, e sim pelo que elas têm.”

D283

R: “Já nas cotas para negros eu também sou a favor, porque os que conseguem ser aprovados foi por muito esforço e mérito, pois competiu uma vaga com outros negros. Infelismente essa diferença os aflinge e assim seria uma maneira dessa diferença o beneficiar ou ao menos o colocar em real igualdade com o branco." (1 25 a 33).

Q1: "O negro até hoje sem duvida é muito discriminado. Isto, pode se notar quando procura por eles entre os próprios políticos. Quantos são negros? Quando tratasse de um bom emprego ou cargo de confiança e o negro tem como concorrente um branco o seu nível intelectual pouco vai contar. Pois é assim que se segue a anos, mas que um dia terá que mudar."

Q5: "O desemprego e a falta de dinheiro pode mexer com a cabeça de um homem, as vezes um homem até mesmo de boa índole, pode vir a cometer erros para conseguir dinheiro. Muitos as vezes não consegue entender por que uns tem tanto e outros tão pouco. todos deveriam ter condições de ter uma vida confortável, mas talves o limite desse confortável é que atrapalha porque quanto mais tem mais se quer ter."

D286

R: “O Brasil é um país, com preconceito de todas as partes, nós deveríamos melhorar isso, muitos políticos falam que não tem nem um tipo de preconceito, mais são os primeiros a ter, se não tivessem, os negros, os índios, os pobres teriam mais liberdade num país como esse." (13 a 9).

Q1: "Vida presa no quintal

Me lembrando desse tempo

Vejo quem vem meu leito festejar

Três meninos nascendo no ventre negro, sem cor

Meninos sentados no chão

Quem veio por eles buscar?

Q5: “O pai de família não tem dinheiro, mais sempre compra, diversão não sabe o que é."

D299

R: "Em relação às cotas, acho que é o começo da igualdade, apesar de que a idéia de implantar a avaliação ao longo de sua vida letiva é fantástica! Pois com toda junção de seu esforço você pode recuperar suas notas e ao longo do curso, sua 
perspectiva. Sendo distinta do ENEM, que para nós estudantes nada nos favoreceu, pode dar mais resultado com a junção de cotas que além de atingir negros deveria dar pelo menos $70 \%$ de suas vagas para que estudou em escola pública e que possuem renda insuficiente para essa necessidade que no Brasil é luxuosidade.

Me tenho como exemplo: sempre tive ótimas notas na escola Estadual, se existissem cotas, certamente eu conseguiria passar para 2 fase, mas sempre trabalhei e estudei à noite, muitas vezes cansada, mas com todo um esforço para aprender e "sonhar" com a faculdade.

Por isso não concordo com a opinião da Ex-secretária Eunice Ribeiro: com todo esse esforço, se ouvesse cotas, eu entraria e não seria menos capacitada no mercado. Tendo em vista a avaliação da Faculdade no tempo letivo, podendo sim, me reter, sentir dificuldades, mas se conseguir me formar, certamente terei a mesma capacidade do instruído em melhores condições.”(1 15 a 37).

Q1: “Atualmente pode não haver escravidão explícita, mas nessa música o relato 'Meninos sentados no chão. Quem veio por eles buscar (...) Nem pergunto pelos filhos.' demonstram filhos que não tem instrução e que tenta a vida e deixam sua mãe.”

Q5: 'O seu status depende da tragédia de alguém.

(...) É isso capitalismo selvagem.”

Nesse caso, na periferia vimos roubos e trapaças sempre por isso indentifiquei esse trecho com a realidade de que só é rico que faz 'rolo' no Brasil.

D321

R: “As opiniões sobre cotas são variadas o que mostra a maioria das vezes é que nem sempre o que se tem prioridade é a qualidade do ensino ou do que vai se aprender e sim a "qualidade" do aluno.

Dificultam cada vez mais o vestibular, o que torna este método um processo seletivo, pois sabem exatamente quem vai passar.

Deveria existir mais opções onde os jovens da periferia e negros pudessem seguir adiante seus estudos sem sofrerem nenhuma discriminação, mais como isto já não é de hoje a briga aumenta a igualdade diminui e mais pessoas são impossibilitadas de concluir seus estudos, seja por falta de verba ou de oportunidades.”(1 16 a 37).

Q1: "Embora não exista mais escravidão os negros sempre se encontram em situações abaixo dos brancos, as pessoas muitas vezes acostumam-se com certas situações e acabam fazendo parte dela." 
Q5: “As pessoas vivem em seu bairro (periferia) uma realidade totalmente diferente do que se vê na sociedade, desta forma acredita que pra ser aceito precisa-se de muito dinheiro, deixam seus ideais de lado e acabam vivendo de utopia."

D335

R: "Falando em números eu discordo do Sr. Aloísio Teixeira deveria sim existir o sistema de cotas em universidades públicas. Mas teria que ser da seguinte forma $50 \%$ destas cotas destinadas a alunos ou ex-alunos de escolas públicas e os outros $50 \%$ para os alunos de escolas particulares e esta também incluindo os negros e deficientes como um todo sem desigualdade e sendo assim que fiquem com as vagas os que, as merecem." (11 a 26).

Q1: “A periferia é o melhor exemplo que tenho se você não entender, basta contar entre dez que vera a ilustre situação.”

Q5: "O que ainda acontece, muitas pessoas desempregadas se embriagando em um bar reclamando da vida que leva, e a desgovernada vida do crime, que faz com que consuma mas do que tem."

\section{D348}

R: "Enquanto ao Sistema de Cotas, ele garante a vaga, mais não acaba com a discriminação Racial.

O negro ele está lutando e reivindicando mais ainda continua excluído por suas condições sociais, sendo submetido ao Branco.

Eu sou a favor da cotas, mais as políticas de ações afirmativas é que vão dar sustentabilidade, vai trazer alternativas para melhor qualidade do ensino, condições de permanência na Universidade, porque o negro ele ingressa, mais não permanece nela devido suas condições econômicas, distâncias e outros fatores que faz com que ele acabe saindo dela.

Vai trazer condições de ingressar também no mercado de trabalho e qualidade de vida para o negro tenha mais direitos e que essa exclusão torna inclusão não só Racial mais Social." (1 25 a 44).

Q1: "Meninos sentado no colchão

Quem veio por eles buscar?

Hoje eu digo 83

Sem diamante, escravidão

Nem pergunto pelos filhos

Ligo o rádio, durmo no colchão." 
Q5: “As pessoas querem conforto, não tem opções. Não tem e não te dão oportunidades, procuram o crime, o tráfico p/ lhe dar essa satisfação e assim causando terrorismo até mesmo contra seu próprio povo, essa também e a força do capitalismo."

D34

R: “A cota de vagas para negros não resolve e nem vai resolver a desigualdade social, porque isso só seria possível se os negros fossem tratados de igual pra igual, tendo as mesmas chances que os brancos tem, aí sim resolveria a desigualdade em relação ao negros." (1 19 a 23).

Q1: “A situação do negro por um exemplo na área do desemprego, tá certo que está difícil para todos, mas pior para os negros que tem mais dificuldade ainda de encontrar um emprego tem cargos que até hoje nunca foi assumido por negros o que é um erro, mas, aos poucos eles vão mostrando seu potencial e chegando onde querem, mostrando ainda que eles não são mais escravos e sim cidadão igualmente aos brancos."

Q5: "É comum ver pessoas reclamando pelas ruas a falta de dinheiro e de emprego, onde acabam roubando e até mesmo matando uns aos outros as vezes por uma quantia muito pequena em dinheiro, havendo disputa em todos os sentidos principalmente na parte do tráfico, o cotidiano da periferia é passar todos os dias noticiários nada agradáveis na TV apenas a mortandade que acontece diariamente.”

D289

R: "Acho que os problemas são muitos e começam lá de baixo, como eu argumentei acima. Creio que a solução seria direitos iguais para todos em Universidades sem distinção de cor (raça), classe social ou deficiência física. Claro que isso seria um sonho de minha parte; até porque vivemos num país extremamente racista, e não é de imediato que se muda coisa que faz parte da cultura, apesar de achar que isso vem mudando lentamente ao passar dos anos, muitas barreiras foram vencidas." (1 38 a 46).

Q1: “Sofredor de preconceitos, acarretado num descaso total dos governantes com respeito a direitos iguais.

Se um branco e um negro, por exemplo, passam por uma entrevista de emprego em condições iguais, o branco levará vantagem na maioria dos casos.”

Q5: “A música quer mensionar que existem pessoas com menos condição que se entrega as dificuldades com facilidade. Para saber que existem pessoas com mais condições, ela se auto-exclue e nem tenta competir."

D227 
R: "Nos Estados Unidos, o ensino médio avançado ao final, quando se trata de discriminação racial ele implantou uma lei que caso o aluno seja negro ele teria, a final de seu curso um bolsa de $30 \%$, para que ele viesse a prestar um vestibular levasse uma modesta vantagem, não sendo obrigado a responder todas as questões, sendo necessário acertar só a metade, para conseguir a vaga na universidade, isso só iria ocorrer no caso da pessoa ser negra.

No Brasil, também deveria ser implantado esse sistema de avaliação com base nestes argumentos do caso do aluno ser negro, pois no Brasil como boa parte do mundo sofre também de descriminação seja ela racial, física ou até mesmo mental. Os alunos negros são visados de em certa forma, como os "rebeldes" e sempre levariam desvantagem em relação aos outros alunos, porque discriminação tem e assim seria uma boa forma de fazer com que ela desapareça de uma vez por todas.”(1 28 a 45).

Q1: “A frase vida presa no quintal ilustra a real situação em que o negro se encontra, por quê ele não pode mostrar por demais a sua face senão iria perturbar muita gente seria melhor ficar escondido, seria mais fácil não se mostrar superior, a sociedade não entenderia."

Q5: “A letra da música mostra o dia-a-dia na periferia, pois, muitos vivem se queixando em portas de bar ou em poder e em até igrejas parece que ninguém tem vontade ou não acredita que pode conquistar mais do que já possui e só conquistaria se alguém acima dele desabace."

D29

R: “Também não são só as pessoas de baixa renda é que não conseguem fazer esses cursinhos, também tem diferença de cor de raça, pois se estiver em uma prova como esta e estiver $50 \%$ são brancos e $30 \%$ são negros certamente na grande maioria é que sai na frente." (1 8 a 12).

Q1: "Minha opinião sobre os negros se resume em que eles são pessoas vitoriosas que já sofreram e que agora eles estão tentando mostrar que são capazes e levantar a cabeça com dignidade."

Q5: “A violência não leva a nada pois eles tem que levantar a cabeça e seguir em frente."

\section{D313}

R: "Eu critico sim as cotas porque sou branca, mais na minha cabeça e no meu pesnamentos, os negros tem sim, mais direito que os brancos para estudar e se formar em uma faculdade. 
Também deveria haver igualdade para todos, e so poderia fazer uma faculdade púlblica, quem estuda e estudou na rede pública e se possível que isso fosse comprovado, na hora em que você fizesse sua fixa de incrisão.

O que eu quero transmitir nesta redação, é que o nosso Brasil fosse feito de justiça e igualdade para todos, entre negros e brancos, ricos e pobres.

E como diz o ditado "Da a cesar o que é de Cesar" (1 40 a 59).

Q1: "Nos tempos antigos os negros sofriam muito preconceito por parte do Brancos, nos tempos atuais ainda sofrem sim por pouco da população, mas não tanto como antigamente. Hoje o negro tem um espaço na parte dos braços, eles agora são tratados como pessoas e seres humanos não como animais e vermes. Hoje graças a raça negra podemos ser um pouco humilde de coração."

Q5: "Pelo que eu pude analizar na letra ele está transmetindo que ele só queria ter uma vida melhor do qual ele tinha, sem ter que robar e matar e acabar tirando a vida de uma outra pessoa.

E o Brasil e Mundo onde vivemos fosse feito de igualdade."

D319

R: "Outros defendem o sistema de cotas, que garantem um número de vagas para negros e de escolas públicas. Esse sistema já calsou muita polêmica, por quê alunos de escolas particulares, são contra e justificam:

- Não é certo tirar vagas da gente. Não temos culpa de ter tido uma oportunidade melhor na vida "(127 a 34).

Q1: "Três meninos nascendo do ventre negro, sem cor

Meninos sentados no chão

Quem veio por eles buscar?"

Q5: “A sociedade e a mídia, impõem valores superfulos, dizendo que é preciso, ter roupas caras, um carro da moda e etc..., para ser uma pessoa de destaque.

Pessoas que vivem na periferia urbana e deixam ser levadas por esses valores, acabam sendo indusidas a cometer crimes, para obter esses "status"."

D260

R: "Em um país aonde se investe em segurança pública e presídios poderia investir em segurança publica e presídios poderia investir todo esse dinheiro em escolas, creches, faculdades publicas e entidades com oficina de cursos básicos para os jovens. No meu ponto de vista, enquanto tiver e existir desigualdade social nunca teremos uma vida digna. Se houvesse um programa forte na educação não era preciso limitar vagas e 
cotas para a baixa população que as vezes não tem acesso a um computador. Devemos lutar contra a desigualdade social, não para obter cotas em faculdades." (1 17 a 33).

Q1: "Vida presa no quintal é como se sente os negros no Brasil atual presos em sua própria sociedade."

Q5: "Essa é a pura realidade que encontramos no dia a dia do povo brasileiro, com a falta de desemprego e oportunidades de viver uma vida digna, tornando mais frequentes roubos, mortes e sequestros nas metrópoles."

D 16

R: "Todo cidadão tem direito de engressar em uma universidade: jovens e velhos, brancos e negros, ricos e pobres, mas o que podemos ver hoje em dia é que a maioria dos que conseguem entrar em uma universidade pública, pertence a classe média-alta da sociedade e a maioria que entra em universidades particulares são de classe média-baixa. Isso não deveria ser ao contrário?” (1 1 a 11).

"Sei que o sonho da maioria dos jovens (a começar por mim) é fazer uma faculdade e se tornar um grande profissional, mais hoje em dia para jovens como nós de classe média-baixa restam duas opções.

1.Entrar em uma universidade particular e ter que estudar tendo que fazer acordo todo mês na secretaria porque não tem condições de pagar ou

2. Entrar em uma Universidade Pública como USP ou Unicamp ou Unesp e etc.

Eu como uma jovem que sempre estudou em escolas públicas e que desejo fazer uma faculdade e não tenho condições de pagar, agradeço a Deus por Universidades Públicas e por cursinhos como o MSU, que nos dá mais chances de entrar em universidades públicas e realizar nossos sonhos."(1 30 a 52).

Q1: “O negro tem sido muito descriminado na Sociedade, apesar de isso não ser muito aparente. Tem difícil acesso a empregos, a estudo e até mesmo à vida, podemos ver nas grandes e pequenas favelas, a maioria dos moradores são negros."

Q5: "Muitas pessoas na sociedade da periferia está sem trabalhar, querem comprar coisas e não tem dinheiro e querem ser "pessoas de destaque", isso leva a maioria a cometer crimes com roubo. OBS: Não quero justificar o fato das pessoas roubarem."

D 131

R: "Tenho 19 anos, nasci e me criei na periferia. 
Sempre estudei em escolas públicas e sempre tive o sonho de fazer um curso de nível superior em faculdade pública.

Mas quando completei o ensino médio o sonho virou ilusão, porque nunca tive um suporte de ninguém nem do governo.

Mas eu e muitos outros como eu que não tem ajuda de ninguém achamos que temos direito de termos uma universidade.

Uma universidade que respeite o nosso nível social e cultural e nossa raça. Acho muito interessante cotas para os negros, mas não é só isso que vai resolver o problema, e não acho que é uma discriminação racial pois realmente a maioria dos negros não tem condições de frequentar uma universidade.

Não vou dizer que o pré-vestibular é a solução mas acredito que seja o começo.

A avaliação do histórico do aluno seria também importante podendo assim dar uma vaga na universidade.

O processo seletivo é legal mas parece que não é em todos os lugares que tem funcionado.

Acredito que a maior dificuldade não seja o conhecimento dos alunos mas o incentivo oferecido pelo governo que não tem como colocar alunos de classe baixa nas universidades, assim refletindo no ensino médio fazendo o aluno perder o interesse de aprender, ele pensa "pra que aprender o que vou fazer depois".

Q1: "Três meninos nascendo do ventre negro, sem cor, meninos sentados no chão, quem veio por eles buscar!"

Hoje o negro não tem classe social, vive sem amparo poucas vezes o governo se preocupa com o negro. Quem será que vai fazer alguma coisa acredito que nem Deus sabe!

Q5: “Todos na periferia almejam ter dinheiro para pagar as contas, ter uma casa mais confortável e um carro. É só ligar a televisão e você começa a querer tudo aquilo que você vê esquecendo que tudo aquilo não é sua realidade."

D199

R: "Para o meu ponto de vista as universidades particulares e públicas cada vez mais não são para nós da classe média baixa.

Pois uma pessoa que está desempregado não pode pagar uma faculdade nem quem tem emprego não consegue pagar também.

As faculdades públicas só quem estudam nelas são os filhinhos de papais. 
Então acho que todos nós que sonhamos em fazer uma faculdade deveríamos lutar para conseguir com que as faculdades públicas desces mais chances para as pessoas que querem ser alguém na vida."

Q1: "Sem diamante, escravidão

Nem pergunto pelos filhos

Ligo o rádio, durmo no colchão"

Q5: "Ultimamente andei ouvindo reclamar

Que a sua falta de dinheiro era problema.

Que a sua vida pacata já não vale a pena."

D 149

$\mathrm{R}$ : "O Governo deveria também, procurar entre si e com pessoas capazes e entendidas no assunto, achar um melhor meio de avaliação, para ingresso nas universidades.

Algo que de direitos iguais a todos, sendo o cidadão: pobre, rico, negro ou branco.

E não pensar apenas em resolver uma parte do problema, criando cotas para negros nas universidades.

O governo deve criar universidades que passem a todos um ensino de alto padrão, para termos profissionais capacitados, pois isso é favorável ao Brasil, em relação as outras nações.

Acho dispensável um ano a mais de ensino médio, pois o que vale é a qualidade do ensino." (1 17 a 38).

Q1: "Sem diamante, escravidão

Nem pergunto pelos filhos

Ligo o rádio, durmo no colchão.”

Q5: “O que acontece nas metrópoles brasileiras, principalmente nas periferias, é a falta de emprego, que leva o cidadão ao crime, pois ele não tem como comprar por falta de dinheiro. Não tem como possuir bens e ser uma pessoa de valor."

D284

R: “A jornalista Daniela Tófoli defende um quarto ano opcional ao ensino médio público no lugar do sistema de cotas onde se prepararia o jovem para o vestibular, de certo, esse quarto ano preparatório é uma idéia que poderia ser acompanhado ao sistema de cotas como parte do vestibular." (1 25 a 32). 
Q1: "O negro é discriminado diariamente pois grande parte dos brasileiros são preconceituosos mas não assumem abertamente."

Q5: "Essa lei da selva é o que ocorre normalmente porque algumas pessoas querem ter mais do que outras, querem ser superior, querem dizer que podem comprar um carro, que são melhores, essas pessoas fúteis querem competir com os outros em tudo, principalmente na sua popularidade querem conhecidas, querem ser o que não são.”

D112

R: "O problema das cotas para negros, embora a idéia seja boa, é que acaba-se criando uma idéia de que para eles foi mais fácil, o que pode tornar sem valor o esforço do estudante negro e do estudante branco também." (1 13 a 21).

Q1: "Meninos sentados no chão.

Crianças nas ruas sem escola morando em favelas e sem perspectiva nenhuma de melhora."

Q5: “As pessoas que moram na periferia e em favelas estão descritas na letra acima por que realmente eles querem um pouco de conforto e serem reconhecidos não conseguem isso, em busca disso roubam pra conseguir status provocando tragédias dos outros.”

D93

R: "Outra medida para tornar mais "justo" o vestibular, seria o sistema de cotas, que garante uma determinada quantidade de vagas para negros e afrodescendentes, que a meu ver é uma medida ineficaz e preconceituosa, já que poderia garantir o acesso de pessoas que possam não estar qualificadas e também não podemos dizer 'Fulano é o melhor aluno negro e Beltrano é o melhor aluno branco', eu acho que não é bem esse o caminho.

Agora a medida que me parece mais eficaz, seria a criação de cursos prévestibulares gratuitos e à ampliação do ensino médio para quatro anos, este último ano seria preparatório para o vestibular.’(131 a 47).

Q1: não respondeu.

Q5: "No trecho apresentado vemos uma pessoa que reclama a falta de dinheiro e pensa que só pode ser aceito na sociedade se tiver "grana", e que não importa a forma de que forma vai conseguir essa "grana"." 
D 162

R: "Somos a maior parte da população brasileira, as pessoas de baixa renda, e aminoria nas universidades do Brasil. Principalmente nas federais. Deveriam proibir que os alunos das escolas particulares prestassem vestibular em universidades públicas. Acho que se eles podem pagar para fazer o segundo grau em escolas particulares. Pagam também para fazer faculdade.

O governo deveria construir mais algumas universidades. Pois o número de alunos nas escolas públicas é enorme nas periferias.

Não concordo que algumas vagas sejam destinadas para as pessoas de cor negra. Com certeza se eles estudaram em escolas do Governo como os alunos de cores brancas tem capacidade para concorrer com todos os tipos de pessoas." (1 2 a 20)

"Todos nós, sendo rico ou pobre, negro ou branco, temos não só o direito, mas o dever de fazer uma universidade.

O Governo por sua vez tem a obrigação de nos dar esse direito. É para isso que ele está lá, e é por um desses motivos que ele recebe todos os meses seu salário.” (1 34 a 42).

Q1: "Três meninos nascidos do ventre negro, sem cor."

Q5: “As pessoas da periferia não tem bens e ao ver grandes empresários c/ carros importados e bens valiosos, acham que a vida, vivida sem dinheiro não é nada. É um lixo."

\section{D222}

R: “Após ler e avaliar todos os textos, uma coisa fica clara, existe uma opinião para cada situação e cada opinião tem uma razão, um porque, um sê e um porém.

Particularmente, acredito que nenhuma dessas avaliações que já vem transcritas e que já tem critério de notas e regras estipulados, seja a maneira certa de avaliar a capacidade de um indivíduo ingressar ou não na faculdade e fazer um

determinado curso.” (1 1 a 10$)$

"Acho que a pessoa mais capaz de avaliar um aluno é o seu professor. Afinal, ele conhece o aluno durante o ano letivo e descobre suas dificuldades, sua forma de se relacionar com os outros, sua forma de encarar atividades e responsabilidades escolares, seus planos para o futuro, seus sonhos, seus problemas sociais e suas qualidades e dons.

O professor pode avaliar o aluno de várias formas e em diferentes situações, pode indicá-los a testes vocacionais e fazer cartas de recomendações ao fim 
de cada ano letivo do ensino médio, dizendo se o aluno está ou não preparado para a faculdade e curso que escolheu." (129 a 42).

"Dessa forma se avalia a força de vontade, a necessidade e a vocação do aluno, indiferente de sua cor, idade, classe social, escola que frequenta ou outros fatores discriminativos.

Fim!"(1 55 a 60).

Q1: “O negro hoje é viso como "empregado". Isto é, quando consegue emprego.

Mesmo havendo hoje, médicos, advogados e empresários negros, esta ainda é uma minoria, que mesmo assim, sofre preconceito.

Nas novelas mesmo as mais belas negras fazem papel de pobres, empregadas domésticas ou mulheres que apanham dos maridos."

Q5: "Descontentamento com a situação social.

Frequentemente se vê pessoas reclamando da dureza de suas vidas. Falta dinheiro, emprego, falta de oportunidades. Pessoas que sempre querem ter o que um outro alguém conseguiu as vezes, até de forma errada. Como se importasse mais ter algo do que ser alguém."

D132

R: "Porque, em muitos casos o problema do aluno não aprender, não ter vontade de estudar, não se interessar por nada.

Não vem dele próprio, as vezes o ambiente onde ele vive, não o motiva ou na maioria dos casos a escola onde estuda e os professores que nela dão aula, não dão o animo necessário que o aluno por direito deve ter e eles não insentivam como devião.

$\mathrm{Eu}$ falo isso, porque eu sei, aconteceu comigo e acontece com amigos meus.

No meu bairro a maioria das escolas públicas, é muito precária a situação e os professores muitas vezes faltam e se não faltam não explicam muito bem as matérias dadas.

Porque esses professores dão aulas em três ou quatro escolas boas (particulares) e vem passear nas escolas públicas da periferia (que é o meu caso).”(1 8 a 29).

"Por um lado, ele diz que não concorda com as cotas para os negros, e diz que não resolvem o problema de desigualdade social no país.

Mas por outro lado ele diz que é favorável a implementação do sistema, ele foi ecoerente." (1 42 a 46). 
"E é isso para mim todos tem o direito, independente de ser negro, branco, pobre e etc." (1 59 a 60$)$. 